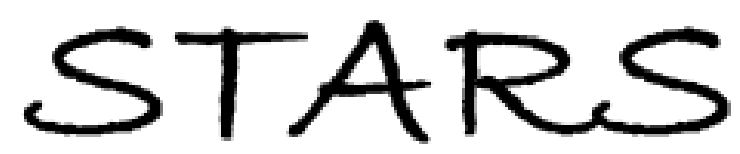

University of Central Florida

STARS

Florida Heritage

Special Collections

1907

\title{
Sunshine and sport in Florida and the West Indies.
}

Aflalo, Frederick G. (Frederick George), 1870-1918

Find similar works at: https://stars. library.ucf.edu/floridaheritage

University of Central Florida Libraries http://library.ucf.edu

This Book is brought to you for free and open access by the Special Collections at STARS. It has been accepted for inclusion in Florida Heritage by an authorized administrator of STARS. For more information, please contact STARS@ucf.edu.

\section{Recommended Citation}

Aflalo, Frederick G. (Frederick George), 1870-1918, "Sunshine and sport in Florida and the West Indies." (1907). Florida Heritage. 84.

https://stars.library.ucf.edu/floridaheritage/84

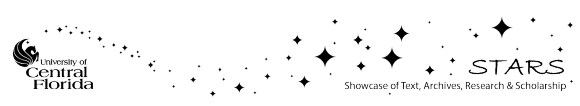





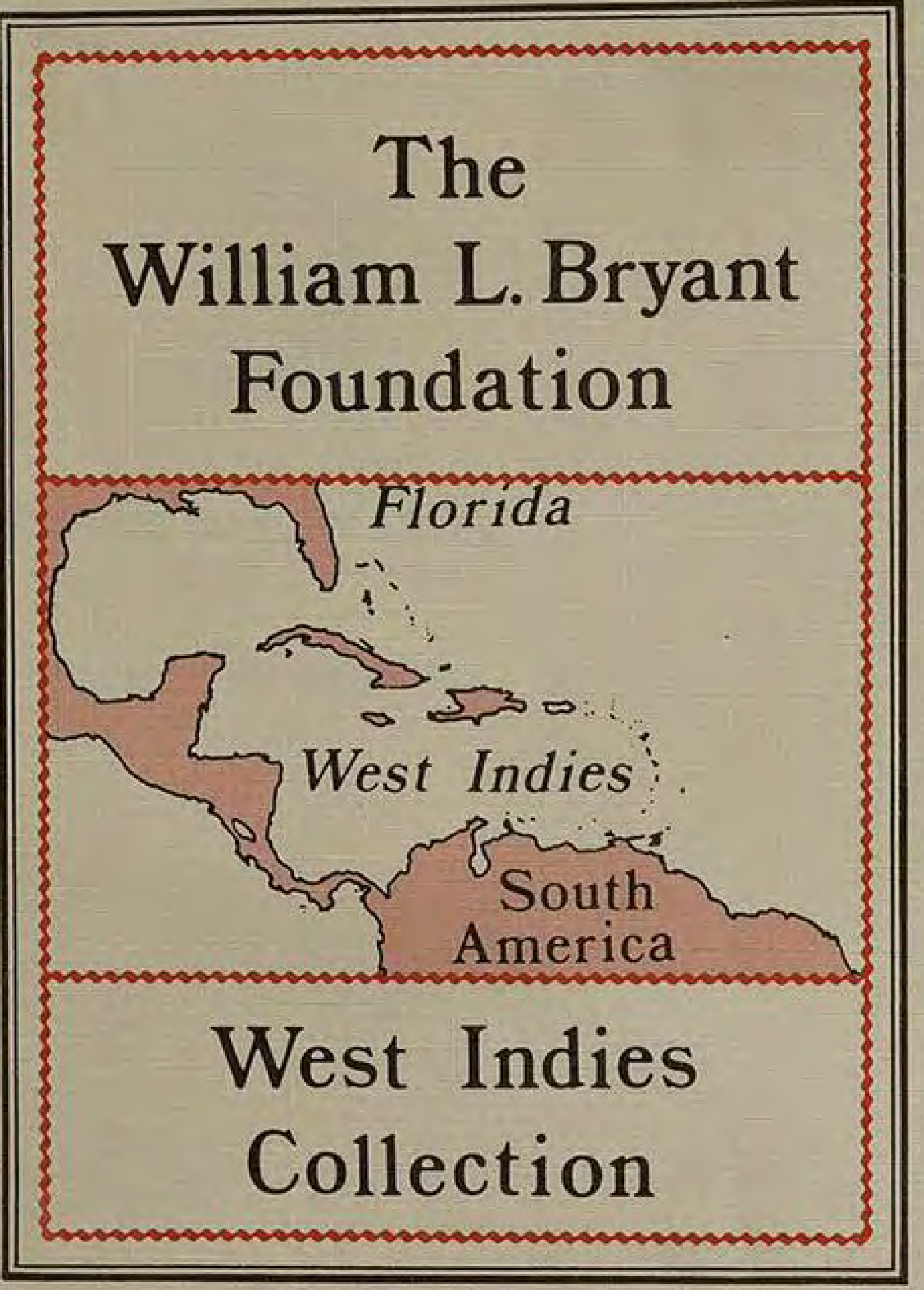




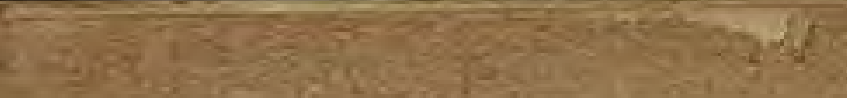

ig. 

SUNSHINE AND SPORT

IN FLORIDA AND

THE WEST INDIES 




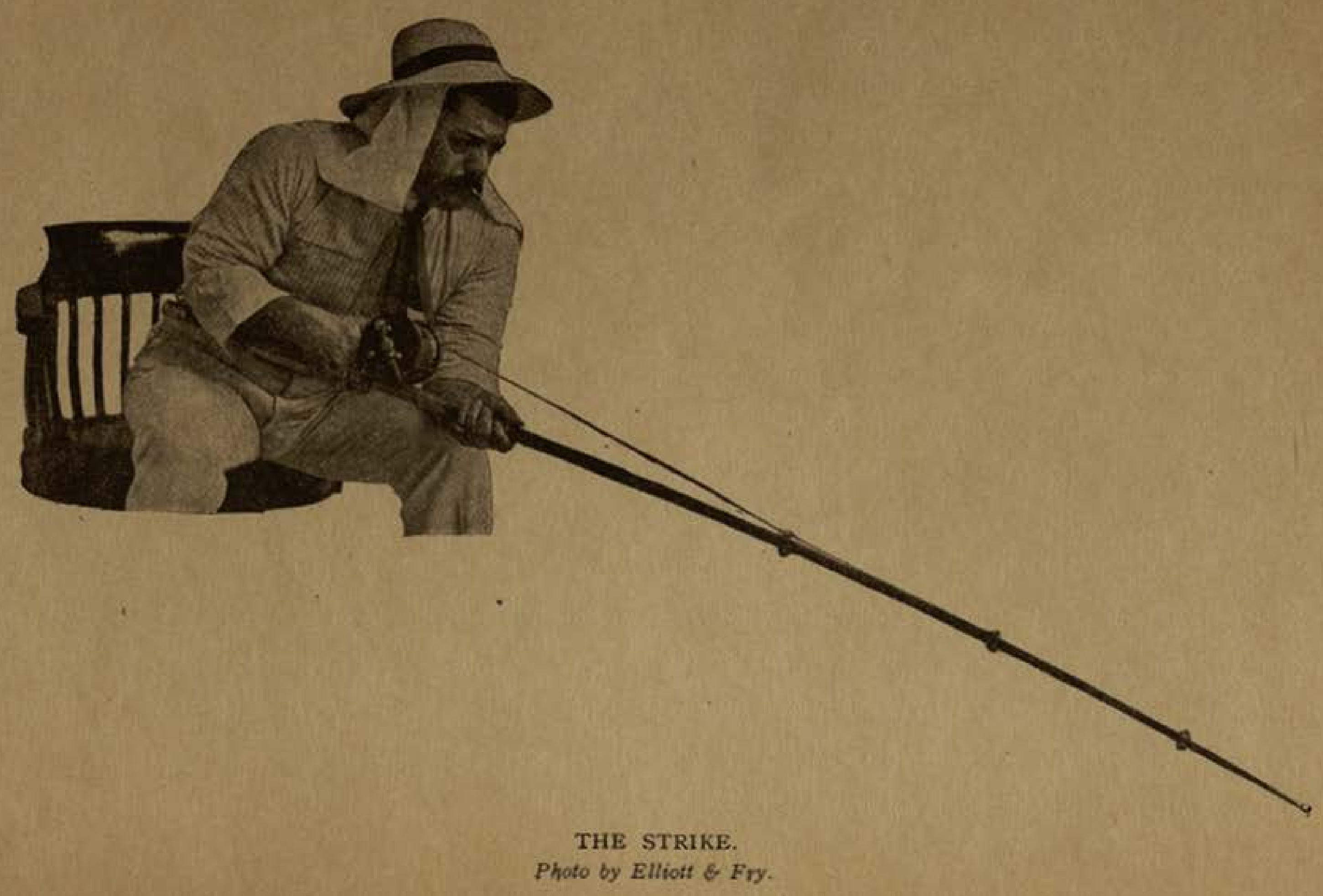




\section{SUNSHINE AND SPORT}

IN FLORIDA AND THE

WEST INDIES $\%$

: \& By F. G. AFLALO

"UND BLENDEND STRAHLT MIR ENTGEGEN

DER SMARAGDENE FRÜHLING DER SONNENGEWECKTE!"

HEINE.

WITH FORTY-SEVEN ILLUSTRATIONS

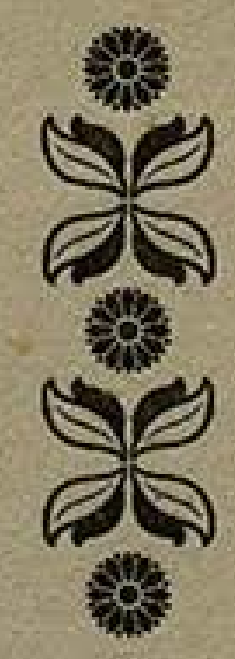

\section{PHILADELPHIA}

GEORGE W. JACOBS $\&$ CO, Publishers 


\section{$\tau_{0}$ \\ THEODORE ROOSEVELT \\ PRESIDENT OF THE UNITED STATES \\ STATESMAN AND SPORTSMAN \\ THIS BOOK IS CORDIALLY \\ DEDICATED AS A SLIGHT \\ TOKEN OF WARM \\ ADMIRATION BY \\ THE AUTHOR}




\section{CONTENTS}

PART I.

THE WAY THERE.

A Cunard crossing - New York Harbour and Customs-Hotels

and Restaurants-Theatres-Streets and SubwaysZoological Park and Aquarium-Railroad Travel in the States-Washington D.C.-An Elegant City-Interview with the President-Congressional Library-Poverty of the Zoological Park-More Railways-The Land of the Sky - Toxaway and its Trout - fishing - Mountain Railroads-Asheville and Hendersonville-Through the Carolinas-A Boorish Innkeeper-Jacksonville-Its Ostrich Farm-A Cavalier of the South-His Memories of the War-Colour Question in the States-Scenery of Florida-Punta Gorda out of Season-A Lesson in Manners-Useppa at Last.

\section{PART II.}

TARPON-FISHING AND OTHER SPORT.

The Glamour of Tarpon-fishing - Day and Night-fishingHeat of Sun and Light of Moon-Great Size and Weight -Importance of Luck and Brute Force-Skill at a Discount-Beauties of the Pass-Lack of the Strenuous Life in Florida-Pass-fishing a Sociable Sport-Life at Useppa Island-Tarpon-fishing Attractive to All-The Cost-Travel Expenses-Heavy Cost of Tackle-A Tackle Bill-Tackle Bought in England-Cost of Living at Useppa and of Boat and Guide-Cost of setting up Trophies-The Tarpon-Little Known of its Life Story -Reasons for this-Characters of the Fish-Curious Long Ray in the Dorsal Fin-The Scales-Tail, Gills and 
Mouth-Maximum Weight and Length-Difficulty of obtaining Records-Two Different Types-Natural Food -An Autopsy - The Tarpon's Character-Its Stupidity - Boldness when Hooked - Its Efforts to EscapeFormula for obtaining Weight from MeasurementsWaste of these Grand Fish-Its Geographical Distribution-Little Known of its Breeding and MigrationCurious Occurrence in Landlocked Waters in the West Indies-A Chance for American Ichthyologists-The Tackle - Rod - Reel - Line - Sinkers - A Foolish Practice-Hook and Wire Snell-Rod Rest-Playing the Fish to the Gaff-Bad Gaffing by the Guides-The Bait -Method of Cutting-Cost of Bait-Bait used in Texas -Originality unprofitable-Stale Bait-Other Baits used in the Caribbean-The Methods of Fishing-Pass-fishing -Description of a Day in Boca Grande-Luck all round -The First Strike-"Make Him Jump!"-A Great Fight-A Fish on the Beach-The Colonel's Big FishAdventure with a Huge Shark-Towed for over Two Hours-End of the Episode-Bad Fishing with a Borrowed Tip-A Lively Afternoon-Success of Ladies $-\mathrm{Mr}$ Vom Hofe and His Turtle-A Kingfish to the Rescue-Reckless Slaughter-Useppa Record for 1906General Principles - Stoutness of Tarpon TackleAdventure with a Foul-hooked Tarpon-A Fish following the Bait to the Boat-Luck versus Experience-The Law of Compensation - Record Luck of Lord Desborough Where Skill comes in-Ways in which a Tarpon may be Lost-Accidents in Tarpon-fishing-Still-fishing-Letter from a Sportsman at Fort Myers-Other Fishing"Vermin" of the Pass-Fishes Caught round Useppa"Trout"-Catfish - Sheepshead-Burrowing Animals Characteristic of Florida-An Alligator Hunt-A Fight with Vegetation - Digging out an Alligator - The Occupant away from Home - A Small Specimen Secured - Natural History Notes - Alligators and Crocodiles of Florida-The Mocking-Bird-Mimicry of Animal Voices- "Whip-poor-will"-Herons and Egrets -Florida suited as a Home of Birds-Bird Protection a Farce-Loggerhead Turtles-Bears and Turtles' Eggs -Shells of the Pass-Snakes-Catching a Rattlesnake in a Butterfly-net-Noxious Insects-MosquitoesGood-bye to Florida-Tampa to Key West-Absence of Beauty in the Latter-Last Memories of Florida 


\section{CONTENTS}

\section{PART III.}

HOME BY THE SPANISH MAIN.

Independence Day at Havana-Position of the Americans in Cuba-Now and To-morrow-Impressions of the Cubans - Havana Harbour-Journey by Rail through CubaIndustries of the Island-Santiago - Steamer to Kingston - Jamaica's Railroads - The Americans and the Banana Trade - Prospects of American Annexation - The Jamaica Nigger-Montego Bay-Moneague-Visit to Cattle Pens-Polo in the Island-On an American Fruit Steamer to Port Antonio-Mosquitoes-Sea and River Fishing in Jamaica-R.M.S. Tagus-Kingston's Disaster - Colon and the Isthmus-Over the Ancon Hospital with Colonel Gorgas-Impressions of the Canal-Visit to the Culebra Cut with Mr Sullivan-The Labour DifficultyPolitical Considerations-Hygienic Work Done by the Americans-Cartagena and its Memories of the Inquisition-Big Fish at Porto Colombia-Great Heat at La Guaira - Memories of Westward Hol-HummingBirds for the Zoo-Beauty of Port of Spain-Bracing Climate of Barbados-Fighting Niggers and Delicious Flying-Fish - The Tagus captured in the Naval Manœuvres.

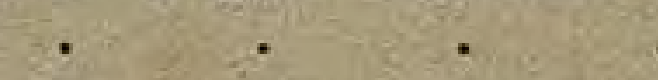




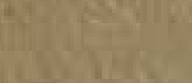

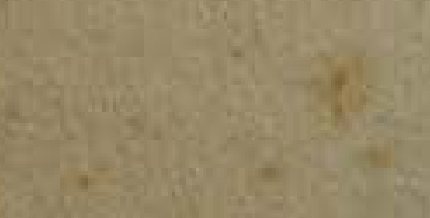

Sethis

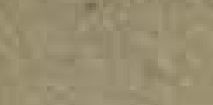

a. 2.325

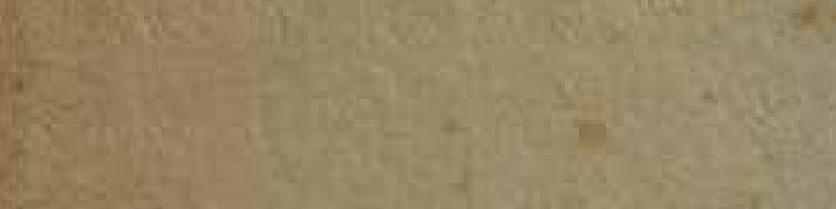

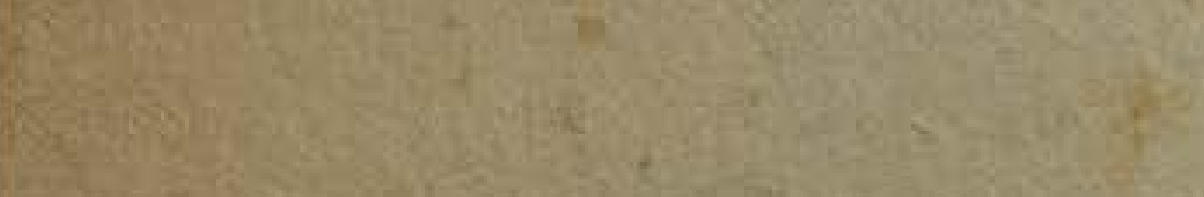

$$
\begin{aligned}
& \text { S. } \\
& \text { Stio: }
\end{aligned}
$$

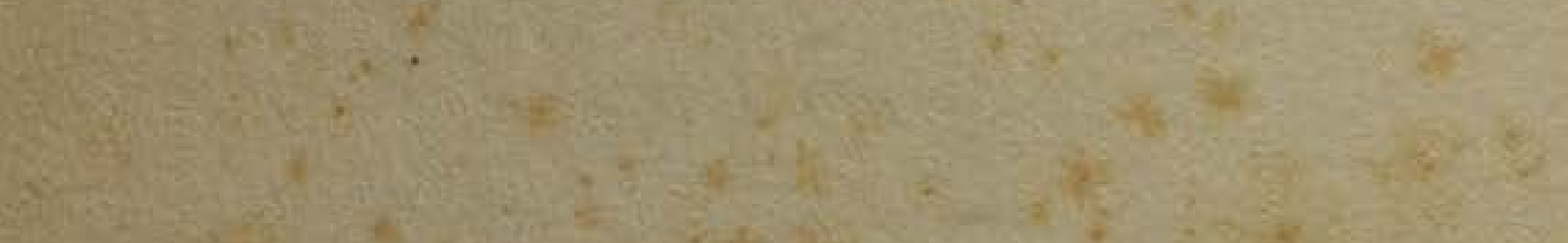

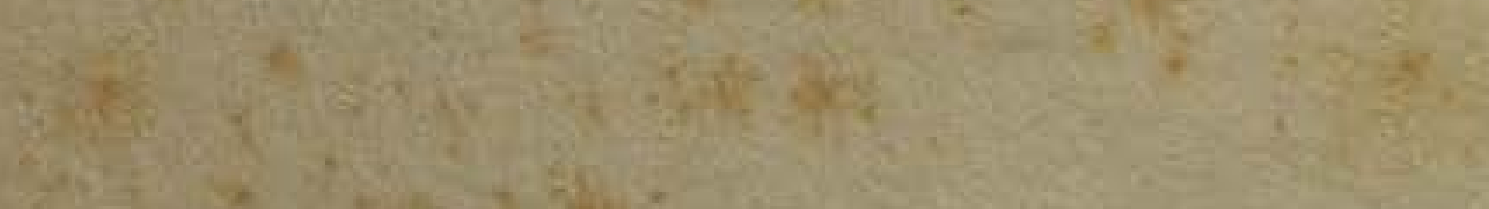

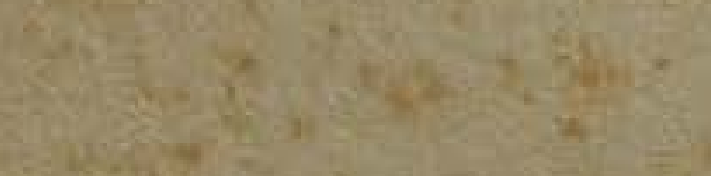

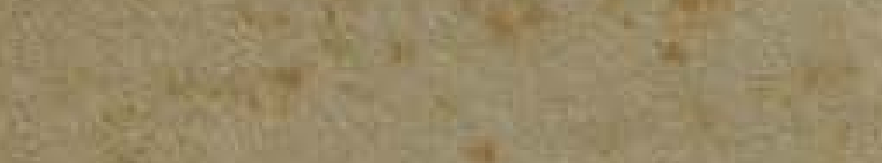

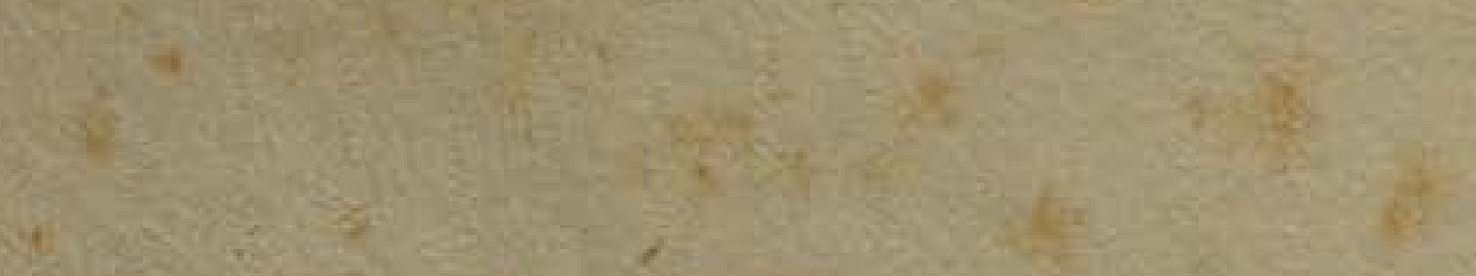

$$
\begin{aligned}
& \text { 4. }
\end{aligned}
$$

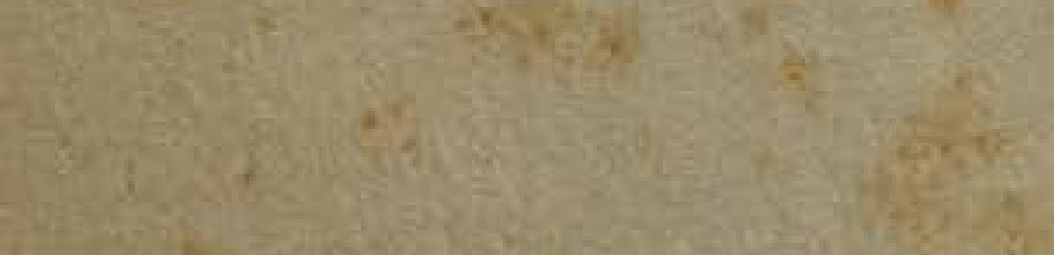

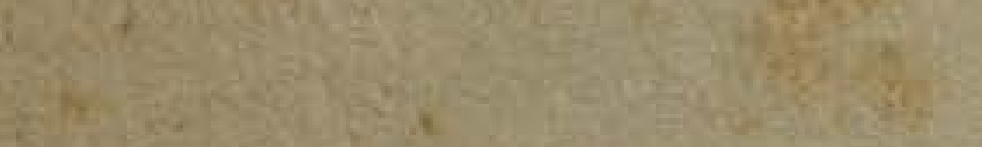

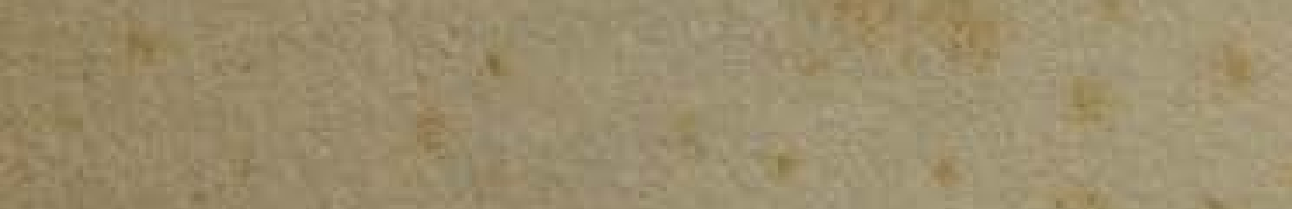

$$
\begin{aligned}
& \text { (3) }
\end{aligned}
$$




\section{LIST OF ILLUSTRATIONS}

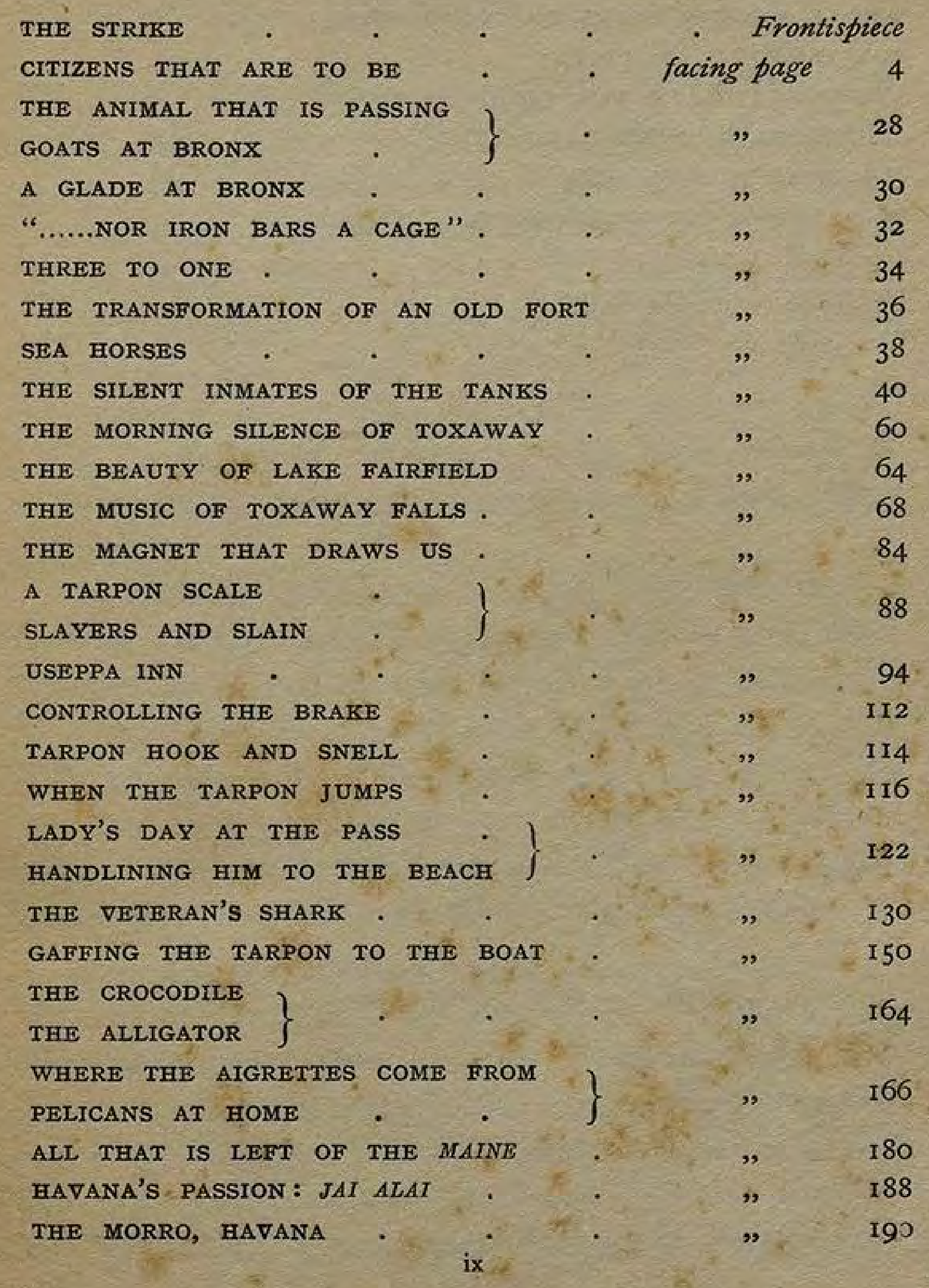


$\left.\begin{array}{l}\text { CERVERA'S LAST DITCH . } \\ \text { HOW KINGSTON LOOKED THEN }\end{array}\right\}$ facing page 196 AQUATICS AT KINGSTON * * * , * 198

A WATERHOLE NEAR KINGSTON $f$
MARKET DAY AT MONTEGO BAY $\quad, \quad 220$

AT THE BIDDING OF THE UNITED FRUIT COMPANY . " " 228

COLUMBUS GUARDS THE HOUSE OF DE LESSEPS $\}$ ", 232

WHERE PANAMA LOOKS ON THE PACIFIC

$\left.\begin{array}{lll}\text { THE HOSPITAL AT ANCON } & \text {. } \\ \text { STEAM SHOVEL IN THE CULEBRA CUT }\end{array}\right\} \quad$ " 242

CARTAGENA AND ITS BACKWATER . . " " 250

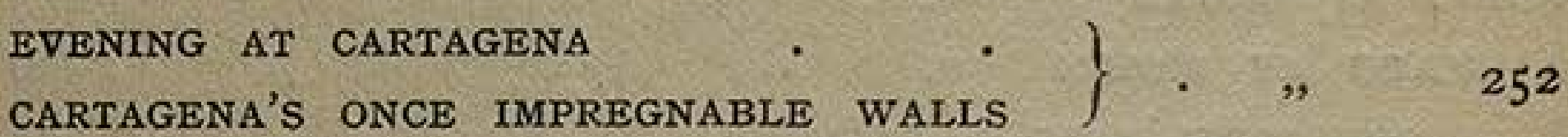

LA GUAIRA, THE DAZZLING • • • • " , 254

WINDSWEPT BRIDGETOWN • • • " * 258

THE CAPTAIN'S CATCH . . . . $\quad$. $\quad 260$ 


\section{PREFACE}

OnE aim of this book is to set before the English angler, with some details not, I think, previously published, the practical and descriptive aspects of the increasingly popular holiday among the leaping tarpon of the Florida passes. As of yore, fishing was the pole-star of eleven thousand miles of travel, and when I contemplate the suggested possibility of this passion dying with the rest as the years grow, I am reminded of the fervour with which the good St Augustine, praying for continency, added, "but not yet."

If, with these records of fishing memories in the Gulf of Mexico and West Indies, I have embodied notes of men and matters by the way, of cities and railroad travel, of scenery and birds and trees, it is with no pretence of having written a handbook to the psychology of the American nation, a disquisition on the Colour question in the States, or a guide to the territories that $\mathrm{Mr}$ Davidson has called-

"Merry England across the seas, Jewelled with isles of the Spanish Main."

The standpoint from which I have seen our American friends, neighbours, rivals, whatever they are, is as different from the extreme rosiness of the sketches written some years ago by $\mathrm{Mr}$ Archer, encouraged by a prominent American resident in 
London, as well as from the acrid candour with which $\mathrm{Mr}$ Bart. Kennedy has, more recently, described them and their country in the columns of the Daily Mail. It takes many folks to make a world, as someone said, and in America I found just as much good and bad as an American would find in England. If I have called a spade a spade, I have used no grosser term, for a man need not make sport of his host's birthmark even if he is not necessarily blind to it. In a land where none mark time, there is so much to praise that a little blemish here and there is not amiss. The nation that has a hemisphere for its birthright has had to encounter terrible difficulties in the making, and the same abuses of trusts and "graft," which is their term for petty larceny on a princely scale, would, in all probability, have been generated in any nation had its moulding been left to the present time. In our envy, moreover, of the inexhaustible resources of the continent and of the irrepressible expansion of its people, we cannot forget the skeleton in the cupboard, the unsolved race problem, the most paralysing influence that ever yet undermined the health of a nation in its childhood. This engrossing question, the theme of many better qualified than myself to discuss it, is but lightly debated in these pages, but I wish that those who have never visited America would inspire their arguments with a little less of the Uncle-Tom's-Cabin spirit. I wish that some of the poor negro's advocates could know the sensation of being hustled off a sidewalk by a buck nigger in the full flush of emancipation. As one result of my itinerary, I was within a few weeks able to see the coloured population in the 
Northern and Southern States, as well as in four West Indian islands of very different political atmosphere, and the comparison was instructive.

Another interesting contrast was that which suggested itself between Cuba and Jamaica from the standpoint of American occupation. Some days in Havana at the time of the annual celebration of Independence, and just previous to the last mild revolution, were sufficient to convince me of the ultimate absorption of that Gilbert-and-Sullivan Government into American suzerainty. On the other hand, a fortnight in Jamaica, during which I enjoyed many opportunities of conversing on the subject with leading Government officials, and with pen-keepers long resident in the country districts, proved that British rule is as firmly established as ever, and that, to whatever extent American capital may be, and should be, welcomed in the development of its banana trade and other industries, American occupation is a chimera that need not be taken seriously. The unfortunate episode enacted by the late Governor and an American admiral rested on a political basis little understood in this country.

A wholly different aspect of American activity in a foreign territory was vouchsafed to me in the Isthmus of Panama, where, thanks to a letter from the President, I was most cordially treated by Colonel Gorgas, the officer in charge of the sanitary operations, $\mathrm{Mr}$ Sullivan, acting Chief Engineer at the time of my visit, and other officials in the Canal Zone, and I was agreeably impressed, not alone with the conduct of the campaign against mosquitoes and the furtherance of the immensely difficult engineering work, but 
also by the conciliatory policy of Washington towards a native Government which, like that of Cuba, owed its establishment to American interference. Many hard things have been said in this country of the hand America took in these revolutions, but would the means by which Great Britain came by her splendid empire overseas bear equally strict scrutiny?

A bird of passage can enjoy no more than a bird's-eye view, and the commercial importance of the Caribbean islands and the romantic interest of the Spanish Main are but poorly honoured in the concluding portion of the book.

I landed in New York on the day after the terrible catastrophe at San Francisco, and it was a fine object-lesson to be with the American nation in its first hours of mourning and to watch the wonderful despatch with which relief trains were pushed off, one after the other, to succour the stricken city of the West. Since my return home Kingston has gone too!

Urbes constituit atas ; hora dissolvit!

Quite a different object-lesson was afforded by the contrast of our own and the American ideal of the salus populi and by the endeavour to grasp their un-English equation of personal liberty. The Englishman must travel on a crowded down-town car, with a couple of labouring men sitting in his lap, to appreciate my difficulty.

At anyrate, I have posted yet another journal of sport in deep waters, imprisoned the fleeting vision of yet another summer gone on swallow's wings, and treasured a few more of those clinging memories of the morning of life, glirrevocati dì, 
that will be so precious towards the hour of sunset. In my travels, I met many delightful men and one great one. I am still uncertain whether that magnificent creature, the tarpon, or the man whose motto might surely be Rem strenuus auge! was the bigger creation.

With my camera, a costly and complicated reflex instrument, I had early quarrel, and in consequence I was compelled to seek assistance from many friends, who responded generously to the call. In this connection, as well as for other help by the way, I have to tender my best thanks to Colonel Gorgas, $\mathrm{Mr}$ Hornaday, Director of the Zoological Park, Mr Townsend, Director of the New York Aquarium, Mr Lychenheim of Havana, Mr Aston Gardner of Kingston, Mr G. H. Ramsbottom, Mr J. Turner Turner, Mr Fearon of Cartagena, Mr Fishbaugh of the Canal Zone, Panama, and $\mathrm{Mr}$ Skinner of Port of Spain, Trinidad.

A gallery of photographs thus collected from many cameras inevitably lacks the continuity of a series of studies specially taken, such as I had hoped to present, but many of the individual results are better than I should have obtained, for the resident photographer is enabled to seize just the most favourable moment, and to avail himself of actinic conditions not vouchsafed to him who comes to-day and goes to-morrow.

F. G. A.

Teignmouth, Devon, Midsummer 1907. 


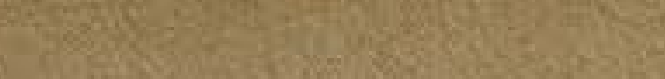

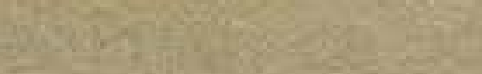

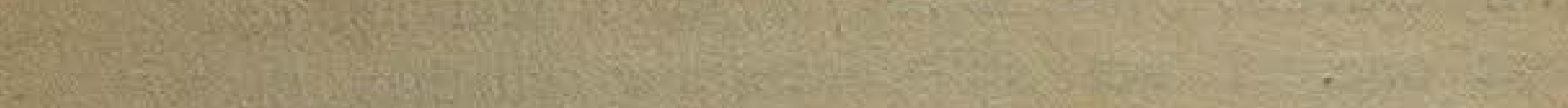

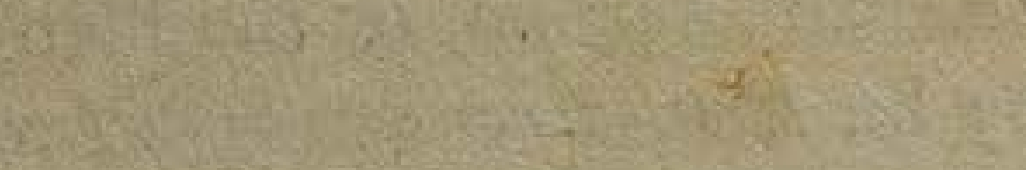

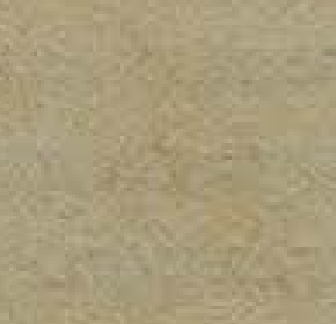

$\operatorname{sing}(\sin 20$

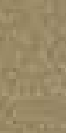

mithosicing

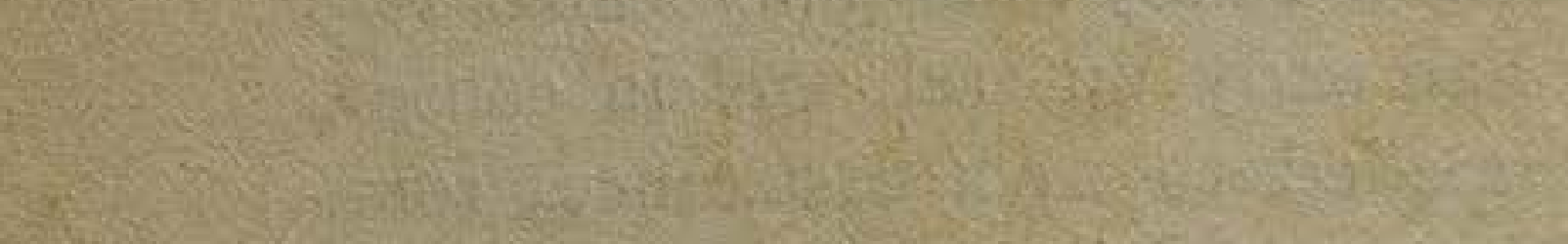

Q.

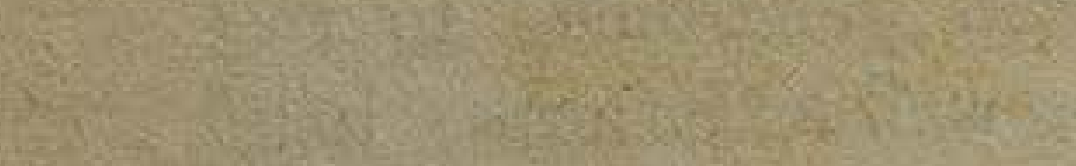

W. (3)

W.

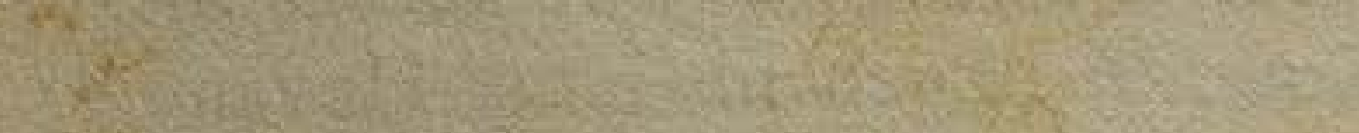
(f)

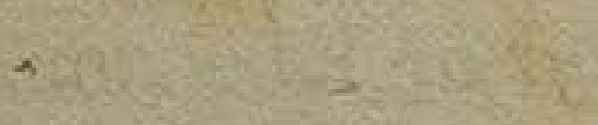

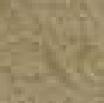

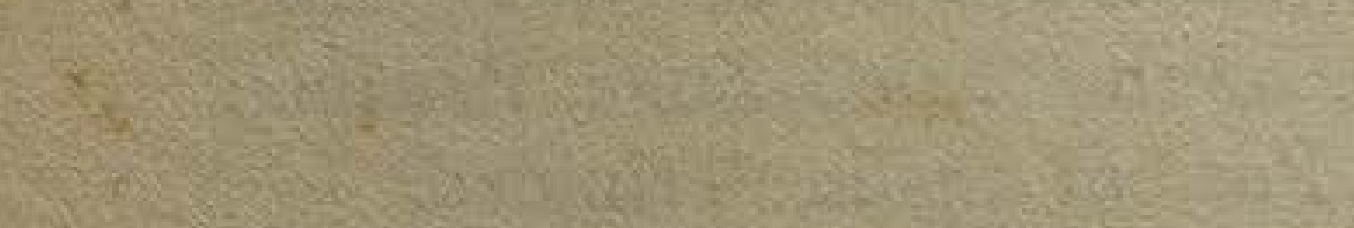

(1)

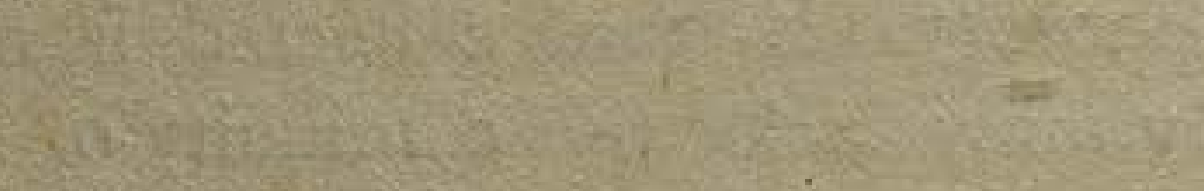

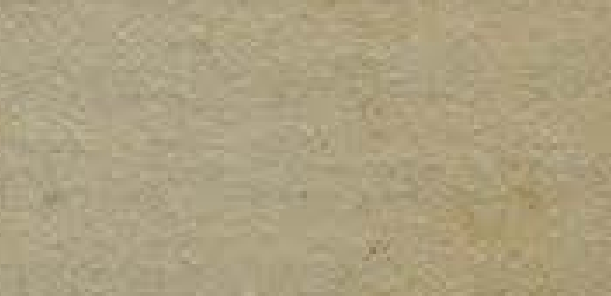

4.

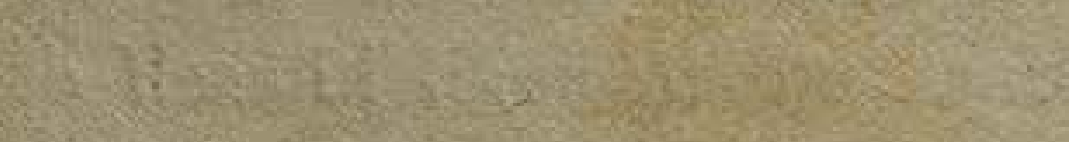

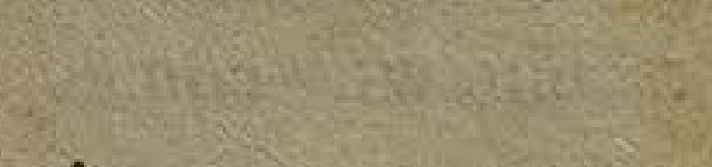
3.
का

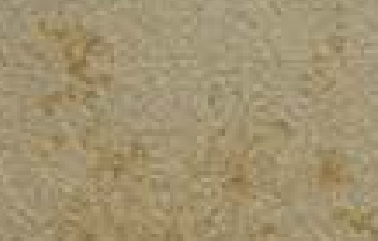

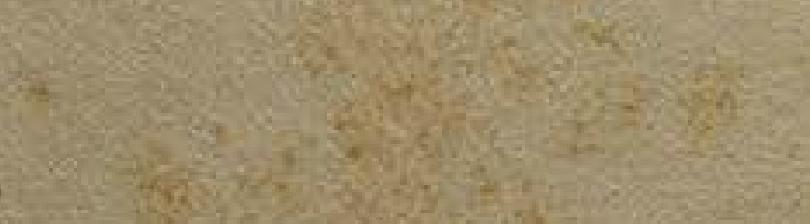

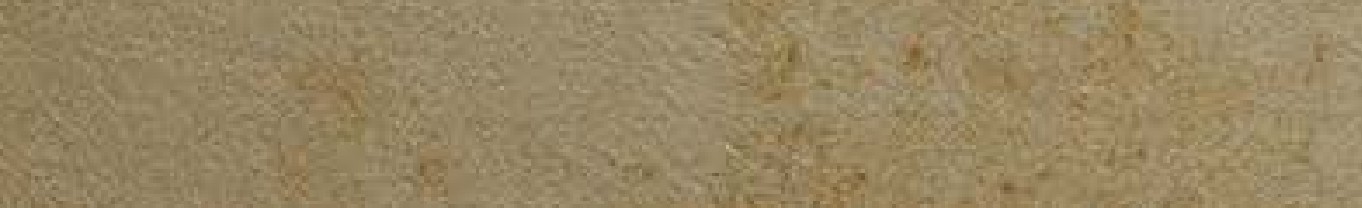




\section{PART I \\ THE WAY THERE}

ACROSS THE ATLANTIC

Ar Euston, the usual crowd, the usual dim eyes, hand-grips, waving hats ; and the long train writhes slowly away from the platform like a great, hissing serpent roused from its lethargy. Some of the passengers are seen off by tearful relatives and have to respond in kind. Others see themselves off, with an early eye to a corner on the shady side of the carriage and a vacancy at the first lunch, so that those who until the last moment hang out of the window for another glimpse of those they leave behind, may have to pay the price of friendship by four hours of sun, never very powerful in April, yet giving even then a foretaste of the coming summer. The rush of two or three hundred when lunch is served is a form of digestive insurance by appetites still unspoilt by wind or wave, for some know not when they may take their next hearty meal, and some of the ladies eat with a zest which recalls the heroine of one of Mr Chevalier's songs. For the gliding landscape few have any eye, and their loss is slight, for the scenery is so homely as to rob the emigrant of his regrets and inspire the returning 
American with pride in his own. With the Pilgrim Fathers, whose gaze was riveted on the fairy coastline of Devonshire, nowhere perhaps equalled on the seaboard of their adopted home, the sensation may have been different, but the midland scenery between London and Liverpool is even more depressing than that between New York and Washington. A boat train is not a social success. Britons thrown suddenly in the company of strangers behave not unlike new antelopes enlarged in their paddock at the $Z_{o o}$. They sniff and stare; they show suspicion and dislike of their neighbours ; finally, they shake down in their new quarters, forget their nervousness, tolerate their fellows and browse as if their lives hung on it. Each one takes elaborate stock of the rest, in some cases to no purpose, for he may never see them again, since the train is feeding two steamers, the giant Cunarder for New York and a trim little Canadian boat for the Dominion.

Within a few minutes of four, the train slows down at Riverside, where lie both vessels, bow to stern, the gigantic Caronia dwarfing the other with her three tiers of decks and six or seven hundred feet of steel and timber. Up several gangways climbs the crowd, each unit for itself, in a mad struggle for the state-rooms, courtesy and dignity thrown overboard. The heavy baggage goes from the van up a separate gangway; the lighter packages give the porters opportunities of playing pitchand-toss, so that old travellers carry small and precious breakables themselves. Little time is wasted in dock, and both vessels soon cast off, first the Canadian, who draws so little water that she 


\section{FLORIDA AND THE WEST INDIES}

slips over the bar just after low water and heads for the ocean. Noblesse oblige! Caronia pays the price of greatness and is forced to anchor off New Brighton for the flood.

Thanks to this and to another delay through fog, she reaches Queenstown ten hours late, and here a couple of tenders discharge emigrants into the steerage. Ireland is evidently not parting with the most comely of her daughters or the most sober of her sons. Yet such are the openings for brain and brawn in the new lands of the West, that these tousled colleens, with draggled hair and fearul petticoats, may live to mother millionaires, and necks that to-day reveal bones may yet shine plump beneath a king's ransom in diamonds. These reeling exiles, who wave unsteady farewell to their friends on the tender, may control Trusts. To-day, they are half-starved; but the time may come for them to corner wheat and starve their fellows. Those squalling brats, who, this sharp April evening, cower shivering against threadbare mothers, will in all probability be drinking champagne at the Savoy while we others still content ourselves with small beer at the village inn. Even those who do not at the last attain to such dizzy heights of refreshment, need nevermore know the privations of life in lovely Connemara. I met an Irishman in New York City. He wore a frock coat and silk hat and ate his four meals a day. $\mathrm{He}$ admitted that there were times when he sickened for a sight of a sweet and dirty village near Cork, but, he added, his yearnings, even after twenty years of strenuous exile in a land of bondage, were tempered by the recollection that 
in the old country he had rarely had enough to eat.

To us, then, enter a thousand of this exiled and homesick Irishry. One day indeed they and their progeny may fix the world's price for wheat and bacon. They have my best wishes. Meanwhile, this April evening, it is a miserable herd that strains dull eyes towards the shores of the green isle now receding behind a creamy wake patrolled by mewing gulls. The remainder of the steerage company is another thousand of assorted wretchedness from ghettoes east of Weser, peasants from the snows of Scandinavia, slum-scourings from the suns of Italy, some patiently gnawing black bread, others fervently breathing garlic. Theirs is the forma neglecta praised by the Latin poet; their physique is mostly consumptive; they wear the expression of dumb suffering seen in overworked cab-horses. What wonder that these poor human cattle should crowd aboard every ocean-going steamer for the Far West. Their motherlands were but stepmothers; life was made a misery at the bid of the sweater or the nod of the autocrat, and then comes to them the blessed promise of the sunset, fulfilled at a fare of less than one halfpenny a mile, food included, with the prospect of a full stomach, self-respect and wages that, for carpenters and bricklayers, are seven hundred per cent. improvement on those paid in Naples, and this with little more than two-thirds of the working hours. $\mathrm{Mr}$ Sinclair has told us with horrid candour that the promise of the sunset is piecrust, but let us hope that the gruesome truths of The Jungle are overdrawn!

Saloon, second-class, steerage and ship's com- 


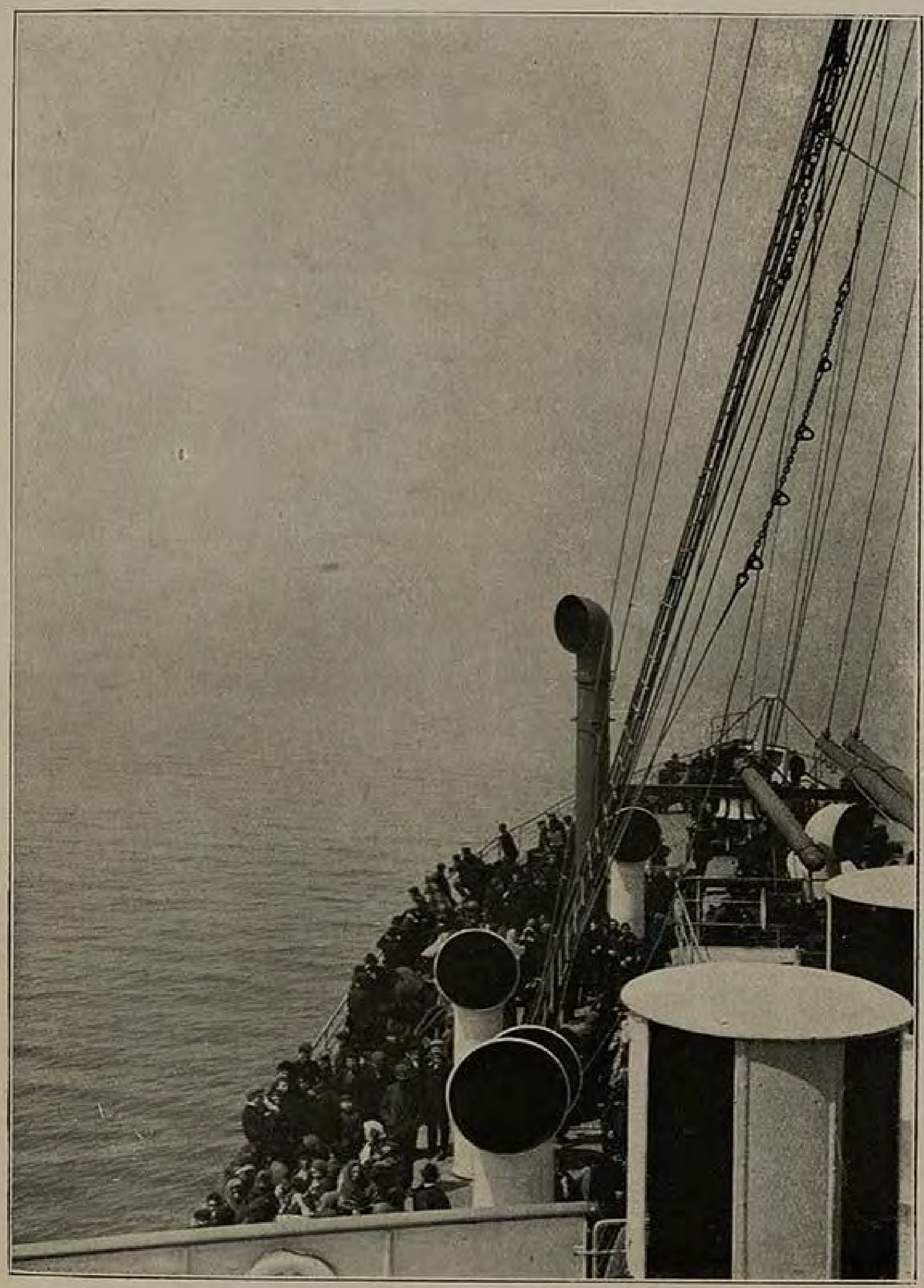

To tace page 4.

CITIZENS THAT ARE TO BE. 


\section{FLORIDA AND THE WEST INDIES 5}

pany total to four thousand souls afloat to-night on the heaving ocean, sorme sleeping serenely, others tossing sleepless in sickly memory of happier times on land, others, again, feeding the fires and lubricating the pistons that enable the graceful monster to plough her way inexorably to the goal. Already at Queenstown she fretted at her anchors with a Jai failli attendre impatience, and as soon as she was clear of the land a heavy beam roll caught her on the bow, and, despite her enormous bulk, she had to own the tyranny of the inclined plane. The concession made vacancies that night at table. In the middle of the ship, soft-voiced stewardesses gently raise thick curtains and say that dinner will be up in a minute. It usually is. Fore and aft there is neither curtain nor stewardess, but one sufferer leans across a neighbour of different race and obeys the irresistible. Everything comes up, even the moon at last, though few pay heed to her beauty as she sails across her kingdom.

The men are either seasick or bridge-mad. In the aromatic fog of the smoke-room, honest fellows rub shoulders with sharpers and, regardless of the caution posted conspicuously on the overmantel, lose their money to beguile the tedium of the voyage. The lounge, luxurious meeting-place of beauty and tobacco, is deserted this second night, for the ladies are either ill or else writing on pictorial postcards purchased on board.

One ocean crossing is like another. A trip that lasts eight days is too long for anyone but a criminal fleeing from justice to be content with his own company ; too short to foster social intercourse, save among those admitted to the freemasonry of 
travel. The sea-life is of necessity inane for all who have no work to occupy their thoughts or muscles. Some of the passengers make themselves agreeable, others make their neighbours miserable, chiefly by inventing all manner of small worries where none exist. As David Harum says, it is well for a dog to have a reasonable number of fleas to prevent him from brooding over being a dog; but he at anyrate keeps his fleas to himself. People on board ship do not. Some lie at full length on deck-chairs, preferably in the way of our quoits or golf; others stride grimly to and fro, as if goaded by the remorse of crimes unspeakable.

At this season of the year, the outward-bound passenger list should be predominantly English, but on this particular occasion a number of Americans were returning from a most successful Cunard winter cruise in the Mediterranean. The American contingent, which for obvious reasons interested me the most, consisted for the most part of splendid women, colourless men, and spoilt children. The women were charming alike in mind and body, a little autocratic with their nominal lords, but this, since the "lords" seemed quite content, was no affair of mine. These had the physique of neurotics and the nervous, peevish manner of the incurable, their complexion anæmic, and their nerves overwrought. Doubtless many of them were endowed with financial genius-one, I knew, must be-but they contrived to hide their talents under a singularly dull exterior. Their women folk, on the other hand, were self-possessed, wellinformed, frank without being vulgar, doing justice to the splendid jewels with which their husbands 


\section{FLORIDA AND THE WEST INDIES 7}

loved to deck them, but always something more than Christmas trees hung with gauds. The children seemed prematurely old and grave, and no wonder. Precocious baby girls played bridge and ate late dinner; precocious baby boys ate late dinner, used long words, argued with their elders unrebuked, and despised, in the strenuous greatness of their republican souls, the simple deck frolic which, as I remember, used to please less sophisticated English lads on P. \& O. steamers bound home from the East. One bookish little Philadelphian, a delightful little prig of nine, with that curious American sallowness that always reminds me of poor Stephen Crane, made friends with me the second day out, and reminded me of one of $\mathrm{Mr}$ Andrew Lang's touching confessions of boyish precocity, for it was easy to picture this serious-eyed stripling reciting snatches of Omar or Ruskin on his way to baseball, leapfrog, or any other occasional game for which his hard-worked babyhood may reluctantly find leisure. Not yet had he transcended that cloudy "If," to which a great countryman of his once referred as a shadow on his youth, and his small, tired eyes looked pathetically out on a world full of the problems with which his infant mind vainly wrestled. In the University on the banks of the Delaware, he doubtless has since enjoyed blessed opportunities of starving his body and feeding his brain.

It is in the steerage that you find the most truly human interest. The alluring green-and-white drawing-room of the first saloon might come from any hotel within five hundred yards of Trafalgar Square, and the second might be a Soho restaurant 
of the better kind gone adrift. Only in the steerage do you touch the keynote of America as the asylum of the downtrodden, for here are the brave who flee from tyranny and starvation, the flight that is no defeat but often the road to victory, and fearlessly set out to mend their fallen fortunes under other skies. With most of these it is a maiden voyage, and Americans returning home are few and far between in that part of the ship. One matron there was from Idaho, most of whose time was occupied in administering a kind of jiu-jitsu, which she called "Hail Columbia!" to a promising kleptomaniac of six, who everlastingly abstracted candy and other victuals from her slender store. I told her that even St. Augustine had robbed an orchard, but she received this cold comfort with a Lutheran snort and the remark that "Those saints were no better than they should be."

A concert was given in each class in aid of the Seaman's Mission, and I had the honour of presiding over that in the saloon. On this occasion I nearly put both feet in it, owing simply to my lamentable ignorance of American affairs. My first offence was against those slumbering hatreds roused by the war of secession, or abolition, or whatever excuse was made for the wealthier political party of a great nation to be at the other's throat. A secondclass concert was given the night before ours, and this I attended in the hope of learning the chairman's routine, for, being fond of music, I had rarely attended ships' concerts in any capacity, and never in that of chairman. There I heard a little nigger boy sing "My Irish Molly," with such rolling of the eyes and other irresistible gestures that, when asked 


\section{FLORIDA AND THE WEST INDIES 9}

next morning if I could make any suggestion before the programme went to the printer, I, as ill-luck would have it, proposed that the child should be put in as an extra. I am sure that it is unnecessary to assure my American friends-I hope that I have some now, if I had few then-that there was not in my suggestion any arrière pensée of a silly and offensive joke. At the first publicity of my suggestion and fortunately before the bill had gone to the printer, two ladies from Louisiana indignantly withdrew their names, vowing that they would not be on the programme with a "coon." I do not presume to judge their attitude. Themselves too young to recollect even the last weeks of a war that laid their country waste, their family may have suffered cruelly, hence no doubt, their hostility to the poor little coloured animal not yet old enough to realise himself as a race problem. Not having yet been invited, the offending "coon" was unconditionally struck off, and when I had made my apologies to the ladies, they consented to sing and gave great pleasure to the audience. Had he been invited, they would, no doubt, have struck him off all the same, only in that case someone else would have taken the chair.

My second offence in connection with the function was happily averted at a still earlier stage by the watchfulness of $\mathrm{Mr}$ Lancaster, the courteous and energetic purser of the ship, who sat beside me through the evening and piloted me over more than one breaker. At the close of the performance, the company stood up for the National Anthems of both lands, and to my amazement the pianist struck up the first chords of "God save the King!" It 
seemed that on a British ship we were to be guilty of the discourtesy of singing our own anthem first, and perhaps I made some gesture suggesting interruption, though I contemplated no more than passive resistance, for my neighbour laid a restraining hand on my arm. Next moment I realised that, with something less than their usual independence of Old World forms, our American friends have borrowed from the hymnal of their old allegiance, and to the old tune have set new words breathing the echo of a patriotic disloyalty and invoking a liberty that knows no bounds. Music phrased for the subjects of a king was now coupled with the passionate declaration of sworn freemen. In my ignorance, I had known only the "Star-spangled Banner," and it had not occurred to me that two national anthems would be required for the fervour of a territory covering less than one-third the area of an Empire that is content with one. Still, the Americans have every right to a dozen if they cannot agree on one, and I have recounted these two unemotional episodes of my chairmanship of the concert merely for the help of others equally innocent of American ways. The excellent charities benefited generously on this occasion, owing in great measure to the liberality of a passenger who anonymously doubled the collection.

Next day was the end, and, considering our slender resources, the week had passed agreeably. The crossing is nowadays robbed of much of the aloofness which used to invest ocean travel in the old days when I went East, by the Marconi installation, without which no self-respecting liner now seems to consider herself seaworthy. A deckhouse, 
radiating wires and buzzing cones, formed an unbroken link with either shore of the Atlantic, bringing these closer, as it were, than those of Kent and Artois from the standpoint of fishing vessels fogbound between them. Each morning at breakfast time we could purchase for five cents $\left(2 \frac{1}{2} \mathrm{~d}\right.$.) an epitome of the news of two hemispheres flashed overnight from Poldhu, in Cornwall, and even two thousand miles from our goal, and a thousand from home, there was no escape from the Lord of Words, and we got the précis of a Potsdam praise of the Algeciras Conference. The Bulletin also gave such meteorological excerpts from the log as might serve to reassure those who were absent from table, comforting them with the information that they had succumbed to the bidding of "high-confused beam seas," and other unrehearsed marine effects of the same order. The realisation that we were no longer cut off from the world came most forcibly to those who received private messages from passing vessels. It was with strange feelings that, one night on the threshold of morning, I was handed a Marconigram from a ship that passed in the night, the Kronprinz Wilhelm, sent by some friends on board who wished me tight lines with the tarpon.

The most interesting afternoon that week for me was one devoted to a tour of the engine-room and cold storage in the company of $\mathrm{Mr} \mathrm{M}$ 'Farlane, Chief Engineer. $\mathrm{Mr} \mathrm{M}^{\prime} \mathrm{F}$ arlane is a Scotsman. Climbing backwards down what seemed to be miles of ladders, I was personally conducted through the Chief's profound kingdom and staggered over traps of bright ironwork, my ears ringing with the 
mysterious hum of unseen forces. Day and night, from Queenstown to Quarantine, this machinery does his bidding without pause or hitch. At night, he can sleep serenely in his bunk-sleep serenely, with a responsibility that I would not wear one hour for an emperor's revenues-in the knowledge that all is well. I followed him past thirteen fierce furnaces that, night and day, must be stoked and trimmed by eighty blackened firemen in four-hour shifts. Beard of Vulcan! Why, four minutes face to face with those blinding coals are more than enough for me, and send me groping back into a cooler darkness. About this submerged world of work there is a strange fascination for those unaccustomed to the sight of it. Little thought do those who yawn on the decks above give to the heroic toilers underfoot. Fortunately, their risk of drowning is no longer what it was, for there is an automatic arrangement of hermetically-sealed bulk - head doors, which, after due signalling with bells and flashlight, can be controlled from the bridge, shutting off from the rest of the ship isolated portions threatened by an inrush of water.

Caronia hurls herself through the ocean rollers with the help of quadruple expansion engines, with thirteen Scotch boilers and a working pressure of $210 \mathrm{lbs}$. to the square inch. A horse-power, figured at 21,000, drives the manganese-bronze blades of her propellers, and she owes nothing to the newfashioned turbine principle utilised in the leviathans lately floated by her owners. The ocean is a mighty force, but she makes little of its dignity. From my plunge into these arteries of the under- 


\section{FLORIDA AND THE WEST INDIES}

I3

world, I emerged by way of the cold storage, where the food of thousands is kept sweet by ammonia freezers, the beef-boxes being in a temperature that ranges from eight degrees above freezing point to seventeen below. That evening I ate with a will, impressed by the hospitality that furnished so much of our floating food, of which, thanks to the Chief Steward, I am able to offer an epitome.

Item $25,600 \mathrm{lbs}$. Beef

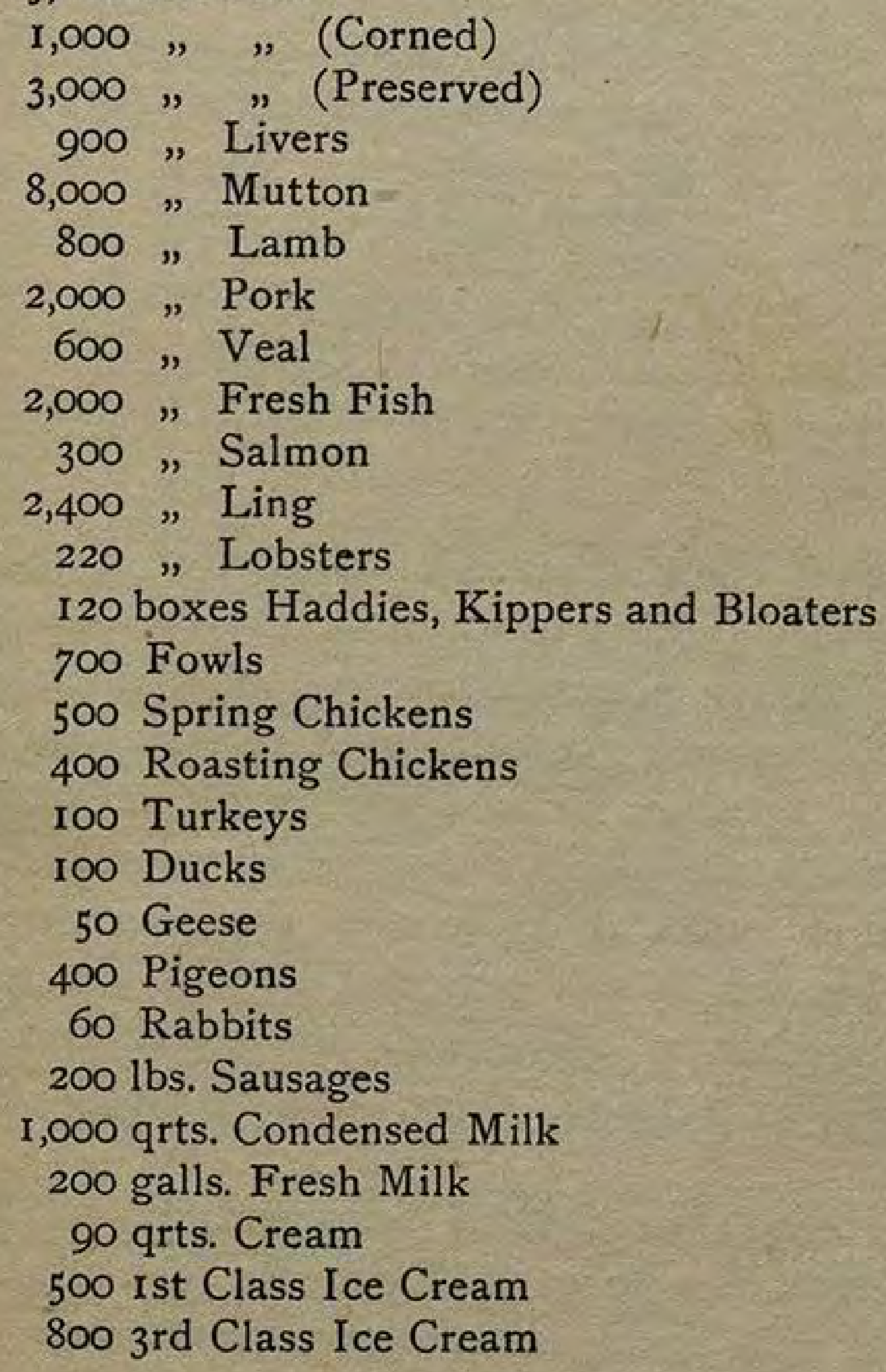




1,800 lbs. Ham
5,000 " Bacon
30,000 Eggs
2,200 lbs. 3 rd Class Coffee
1,800 " Ist Class Coffee
270 barrels Flour
35 boxes Apples
24 barrels Apples
40 boxes Oranges
500 lbs. English Grapes
I2 boxes Foreign Grapes
10 " Lemons
I5 " Pears
350 lbs. Tomatoes
12 bunches Bananas
550 lbs. Nuts
26 tons Potatoes
4,800 lbs. Butter
5,600 " Moist Sugar
1,896 "Refined Sugar
5,600 " Cooking Sugar

Such is the raw material, or part of it, that goes to the daily making of three admirable menus, with corresponding plenty elsewhere in the ship. To some the merest glance at such Gargantuan provition for a week at sea will bring memories of dreadful foodless hours that were spent in tossing on ruffled bunks regardless of the steward's overtures, but others will scan the list with the grateful memory that if there was not much else to do during the passage, there was at least enough to eat.

At length we sighted Sandy Hook and halted at the Quarantine to undergo the not too severe medical and fiscal examination prescribed by the 


\section{FLORIDA AND THE WEST INDIES I5}

Republic for its visitors and home-coming citizens. In no other protectionist port of my travels are the Customs officials so reasonable with those who make frank declaration. I understand that citizens, as well as visitors, who "monkey" with the officers, are treated with less generosity. Well, citizenship of the United States is a privilege that doubtless entails its obligations, and if monkeys will play tricks they have only themselves to blame if others pull their tails. I had been duly alarmed with the prospect of exorbitant charges on my personal belongings, but my English rifle and fishing-tackle got through unchallenged, and the only doubtful article in my luggage was a small typewriter, which proved on examination to have been made in Chicago! With Free Trade it is said that America would whip the world, but the resulting fall in wages would ill suit the working-man, who is master of the suffrage. How far his control of the political destinies of his country works for its ultimate benefit is a question that I am fortunately not called upon to discuss here.

New York harbour held out gracious welcome that sunny April afternoon to eyes that had wearied of unbroken sea and sky, unfolding undeniable beauties as we passed slowly between its narrowing shores, yet not seriously comparable with the panorama of Sydney, Havana, or some other harbour scenery that I could name. A charming American lady went to the trouble of pointing out for my benefit the skyscrapers and other landmarks of her native city, nor did her animation sustain a more than momentary check from an immense legend that disclosed in Brobdingnagian letters 
certain domestic virtues of Hunyadi Janos. How many women, I wonder, of any other nation would so gracefully have carried off the contretemps as to relieve a casual acquaintance of all embarrassment. Here ended our short voyage, and those who for the moment had bowed to the greatest good of the greatest number, all for each and each for all, resumed the tigrine demeanour they had last favoured on the Liverpool quay, and pushed and kicked and scrambled until they had won clear of the vessel.

The conclusion of sea voyages has always, or almost always, been linked in my memory with the receipt of untoward news. On one occasion I landed at Sydney to learn that a firm, in which I had a financial interest, was on the verge of insolvency. On another occasion, I went ashore at Aden to learn of the death of a favourite cousin. This time I anticipated no such unwelcome shock, for the wireless contact with both continents ought to have protected us from such unpleasant surprises. As it happens, the daily Bulletin is not issued on the last morning, and it was not therefore until we were boarded by officials at Quarantine that we had news of the terrible catastrophe at San Francisco the night before. During my stay in New York I watched the impressive spectacle of a great nation mourning its dead and giving of its boundless charity to such as remained of the living. I saw the veteran Mark Twain hand back a two-hundred-pound lecture fee at the Carnegie Hall, and I heard announcements at the theatres of the generosity with which New York's millionaires had given of their millions, so eager were all to swell the relief 


\section{FLORIDA AND THE WEST INDIES 17}

fund according to their means and to send help to the shaken, stricken city of the Golden West. San Francisco buried its dead. They rest from their labours. New York succoured the living, and not New York alone. "Pity and need make all flesh kin." 
TALL buildings, tall fortunes, tall things generally appeal to some eyes more sympathetically than to others. The gospel of the skyscraper, the ethics of the Oil Trust, do not command the respect of all alike. That there is something indefinably impressive about the hustle and haste of this long and narrow island city is undeniable. Whether even its own citizens think it really a thing of beauty, I am uncertain. The lady who, on board the ship drawing to her moorings, introduced me to its roofs from afar, called it so, but in her voice rang a halfdefiant doubt. And yet, and yet there is a hypnotism about its tiers of hurrying, money-hunting traders, herding in the streets and over bridges, soaring to overhead railroads and delving in brightly illuminated subways, that, having in the ordinary way no warm love of the life of cities, I essayed in vain to resist.

He who comes to New York fresh from the unsophisticated expenditure of European capitals gets early indication of a new standard of living. A fifteen-shilling cab fare from the docks to his hotel on Fifth Avenue, a drive that half-a-crown would cover from any London terminus, is quickly succeeded by a charge of a sovereign a night for a room. True, the cab is better upholstered and may be even better horsed than the average London 


\section{FLORIDA AND THE WEST INDIES}

growler, and the driver, with his warm brogue and expensive dignity, may be descended from the Kings of Connaught. True, also, the bedroom, with its private bathroom, telephone, escritoire, and roomy hanging cupboards, would not disgrace the embassy of a first-class Power, and is lit with a blaze that would do credit to the window of a Bond Street jeweller. This luxury is the keynote of life in the United States so far as cities go, with a corresponding squalor in smaller or more remote centres that is unknown in older countries. Much of the comfort of hotel life would be gladly missed if only the charges were more reasonable.

It was surely Gilead Beck who described New York as a hard city for the man without dollars. Money talks there and can buy everything but quiet. If Americans wanted quiet, they would seek it in London or Paris; in New York, the only rest is in the cemetery. The fact is that no living American wants rest until he is dead, and then the cemetery does well enough. The daily routine is one long breathless pageant of hustle and fret, of beggar-myneighbour and the breeding of greenbacks. The streets, long, regular and well-paved up-town, but abominably out of repair down east, impressed me much as they would impress any other hater of great hives. During my first walk from the safe precincts of my hotel, I realised that a man must push or be pushed, for there is not room for all on the sidewalk. I stood one evening on Brooklyn Bridge, a little above the highly electrified focus of many cars, in an eddy as it were of the human tideway, and thence I watched a third of New York surging back over the river, men fighting like wounded grizzlies 
at bay in order to win through the press. The tailor's legend "Clothes pressed while you wait" flashed across my mind as an appropriate inscription for the stately arches that span the interval between the city and its growing suburb. Twenty years ago I had thought the daily ebb and flow of city clerks across London Bridge a bewildering maelstrom, but, compared with the torrent between New York and Brooklyn, the passing of London's suburban penmen was a stagnant backwater.

To accommodate a population so great, so growing, so restless within the narrow limits of the island, it has been found necessary to model the architecture on the Tower of Babel, hence the flat-iron buildings and other skyscrapers, some of which stagger the perspective of the unaccustomed eye. Vertical expansion only is possible with water on every other side, and already the subways dive as far underground as the overhead runs above it, so that the citizens are at once but a little lower than the angels and a little higher than the devil. (Geographically, I mean, of course). A very perfect system of elevators, compared with which our lifts at home are toys, does much to mitigate the rigour of these constant ups and downs, and in American cities the ascent is no harder than the descent. I have found myself deposited on the nineteenth floor of a building in less time than it takes to write it down. Arrived there, though by no means at the top, only the bird's-eye-view from a window enabled me to realise how far I had risen in the drawing of a breath. The subways up and down town also work admirably and are, at the moment of writing, the last word in that scientific 


\section{FLORIDA AND THE WEST INDIES}

underground transportation, of which we in Europe are, under American teachers, only spelling the alphabet. For a uniform five-cent fare, which is become so much a part of the American economic creed that an attempt to increase it in the suburbs of New York recently led to a riot, those who use the subway can fly across the city from Brooklyn Bridge out to West Farms, and express trains, available by transfer tickets, make the transit between remote points very rapid. The street cars, which also favour the five-cent fare, are equally efficient, and would be still more pleasant if, as is done in every other civilised country, the number of passengers were limited by statute to a reasonable number.

The food of any city at once luxurious and poverty-stricken does not differ appreciably from that of other capitals. Here, as there, Dives battens on surfeit, and Lazarus looks with pinched face through the window. There seems no remedy for these evils, and if the dreadful contrast is a little more appreciable by reason of the narrowness of the city and consequent proximity of what Sancho Panza calls el tener $y$ el no tener, this is unavoidable. If there is one feature in which the table attractions of this city are a little behind those of some others, it is in the wine list. There is an admirable injunction in the First Epistle to Timothy, which Americans as a rule disregard. The majority drink iced water with their meals and cocktails between times, so that possibly, in the restaurants at anyrate, rare vintages would go unappreciated. In the better eating-houses, food is expensive. The decimal coinage of the country would be admirable, so only 
a man had enough of it. In a land where bricklayers can earn $£ 300$ a year, and where waiters make a salary that would content a bank manager in a cathedral city, European incomes go no way. I dined, once by invitation, the second time alone, on successive evenings at two of the noted resorts, Sherry's and Delmonico's, which stand vis-à-vis on Fifth Avenue, at opposite corners of some cross street, of which I forget the number. At each I found excellent French cooking, beautiful women, who dined in immense hats crowned with bobbing aigrettes, and on every table bottles of Poland, Apollinaris, White Rock, or other mineral waters then in vogue. At Sherry's, three or four dollars are soon consumed in the shape of little neckclams, a dish of soft-shelled crab, of which you eat legs and all, a fillet with mushrooms, an ice made with fresh strawberries, and a cup of coffee, not, it will be seen, a very sybaritic repast, yet well served and quite enjoyable, even at the price. When I recall the name of Delmonico, memory smacks ghostly lips over a capon financière, a celery salad, and a peach rosadelle, the last a wonderful combination of a fresh peach, a fruit ice and a hot sauce, named after the late Madame Rosa Delmonico. Bust of Handel! To such a sweet I would rather give my name than to an oratorio!

With my visit to Sherry's, I shall always associate an amusing episode. I was dining with some Americans, and a lady of the party had assured me that during my stay in her country I should see little intemperance anywhere, and in polite circles none. I did not defend the drunkenness at home from her innuendo, for, strictly speaking, it is not 
defensible, but I waited with confidence to see what I should see. I could hardly have hoped that my very first evening on shore, and at so fashionable a house, would plead for me and convince the lady that her countrymen are much as others, but so it turned out. We had not been there half-an-hour, when I espied at another table, not far removed, a well-dressed youth so very drunk that he squinted appreciation of the empty magnum at his elbow. In full view of the whole room, which did not show the surprise I had looked for, he was presently assisted to the door by a shamefaced friend and two waiters, resenting such help with the reiterated assurance that he was a gentleman. My fair neighbour was so clearly distressed by the behaviour of her compatriot that I had not the heart to chaff her, indeed it was more pleasant to be able to write to her a month later, confirming her curious prophecy, that this was the last case of intoxication that I should see during my sojourn on American soil. Not in fact until an evening in May, exactly one month later by the dates, did I, leaning over the rail of the Olivette, bound for Cuba, see a top-heavy dock labourer on the wharf at Key West; these two, and none between.

The ordinary table food in houses differs little from ours at home, though the butter is not always good, and most of the biscuits, or crackers as they are called, are unmistakably inferior to those of Reading. In provincial towns (which natives call cities, and cities they will be by the time the next generation is grown up), the coffee is far better, and the tea far worse, than in England. I have no 
statistics to go upon, but it would not surprise me to learn that Americans, careless of nerves, uric acid and other caveats of modern medicine, consume more coffee than even Frenchmen and Germans, rarely substituting the generous wines of the one or the fuddling beer of the other, but drinking coffee morning, noon and night, as Arabs pray, drinking it indeed as regularly as Australians drink tea. The American does not trouble tea much, and no wonder, for his tea is vile and vile remains, being so little in demand. It may be that his contempt for the favourite beverage of England is a survival of that wondrous epoch of secession, when even the rule of the road was reversed and made to conform to that of Continental countries, in order that the new nation might differ in every possible detail of the daily life from the parent stock. As one humble result of this passion for distinction, the few provincial Americans who keep tea at all, innocently offer you stuff that might soothe an American child, but that would, at home, certainly be refused by the kitchen-maid.

Allusion has been made to the prevalent taste for iced water at table. When a man staying in an English hotel asks for water, it may be surmised that he desires to shave or to wash. In the States, he wants to drink it. One evening I got back late to my hotel and asked the clerk at the desk whether I could get a drink at that hour. To my amazement he replied-

"Stop a bit; I'll get you one; I keep a little stock handy."

He dived behind a screen, leaving me embarrassed with vague thoughts of giving him 


\section{FLORIDA AND THE WEST INDIES 25}

a cigar in exchange for the whisky plain, or possible "Tom Collins" that he was so obligingly about to produce, and my doubts were relieved, though not my thirst, when he presently reappeared with an immense beaker of iced water. With profuse thanks, I drank it.

The American takes his tobacco in the form of frequent cigars, generally of medium quality. Cigarettes are rare, though the French colony in New Orleans is said to favour nothing else, and of pipes I saw more in Carolina and Florida than in the cities of the North, where even men of the working-class smoke only cigars. In England, on the other hand, cigars are popularly regarded as an indulgence of the well-to-do, and a certain Cornish crabber of my acquaintance, who has for years smoked nothing else, is on that account regarded by his fellows, who in their blackened pipes burn unspeakable vegetables, with a mixture of awe and suspicion. American cigars, being a common vice on Fifth Avenue and in the Bowery, vary in quality. One man will press half-dollar cigars on you at the rate of three an hour, dispensing with a case and keeping them, apparently in excellent condition, in his breast-pocket. The Englishman says, "Have a weed," and then wastes five minutes fumbling with his case. The American holds the weed out to you without a word of invitation. Again, you come across decently clad skilled labourers who burn between their suffering lips cigars at a "nickel" ( $2 \frac{1}{2} \mathrm{~d}$.), composed of such fearful fuel as would stun a Lancashire pitman.

Of American theatres and other places of amusement so short a stay gave me little knowledge. 
One typical melodrama I saw at Belasco's Theatre, entitled The Girl of the Golden West, the plot of which was based on life in the old mining camps of California. Miss Blanche Bates, an extremely clever little actress, sustained the trying rôle of the only woman in a heavy caste, and some of the "pictures" relied on wonderful effects of lighting. One of the most thrilling of many dramatic situations was that in which a wounded highwayman, hiding in a loft, is betrayed to the pursuing sheriff by his life's blood oozing through the rafters on the hand of the sleuth-hound beneath. Even the dear old Adelphi in its halcyon days offered no stronger meat than this. Alas! how I should have enjoyed it all twenty-five years earlier, who now found it hard to refrain from hysterical laughter. The love of an American audience for a display of the primitive emotions is the eternal joy of their playwrights, and these score heavily with homely pathos that would fall flat on a company of older civilisation. Americans often pretend to be ashamed of their easily-stirred emotions, and sometimes feign a callousness foreign to their nature. Many amusing tales might be told to illustrate this weakness of theirs. A famous New York Mayor was supposed to tell of himself that on the morning when his father died of a seizure he was eating a buckwheat cake at breakfast when the nurse came to report that the old man was sinking fast.

"Before I was halfway through a second buckwheat cake," he is supposed to have added, "she came again and said that the old man was dead." They have also a partiality for anecdotes bearing on "graft" and other roguery. "Good Lord!" 
someone is supposed to have exclaimed on seeing a famous millionaire strolling along Broadway; "there goes — with his hand in his oren pocket."

The only other house of entertainment that I visited in New York was the Hippodrome, the very paragon of Hippodromes, where they give blazing ballets to the plash of perfumed fountains, everything on the colossal scale that alone can captivate the senses of New York. At the theatres, the absence of evening dress in the stalls, the bulky programme, which attains the dimensions of a magazine, and the fashion of handing round glasses of iced water during the intervals, are the chief reminders that New York is not London.

Of all the city's sights, the most interesting to myself were the Zoological Park, out at Bronx, and the Aquarium, which occupies a disused fort in the harbour.

The Zoological Park, though far from completion at the time of my visit, had already surpassed every other institution of the kind, and, in seeking the causes that have contributed to this success, it would be difficult to over-estimate the effect of the Director's enthusiasm. $\mathrm{Mr}$ W. T. Hornaday, a much-travelled sportsman with a genius for organisation, was just the man to deal with a problem that would puzzle many of equal, or even greater, scientific attainments. He came to it from similar employment elsewhere, but here for the first time he found himself unopposed by the cheese-paring policy, so un-American and so discouraging, that had hampered all his earlier efforts. His hands were free to give shape to his dreams, and when at last he says his Nunc dimittis, he will also have 


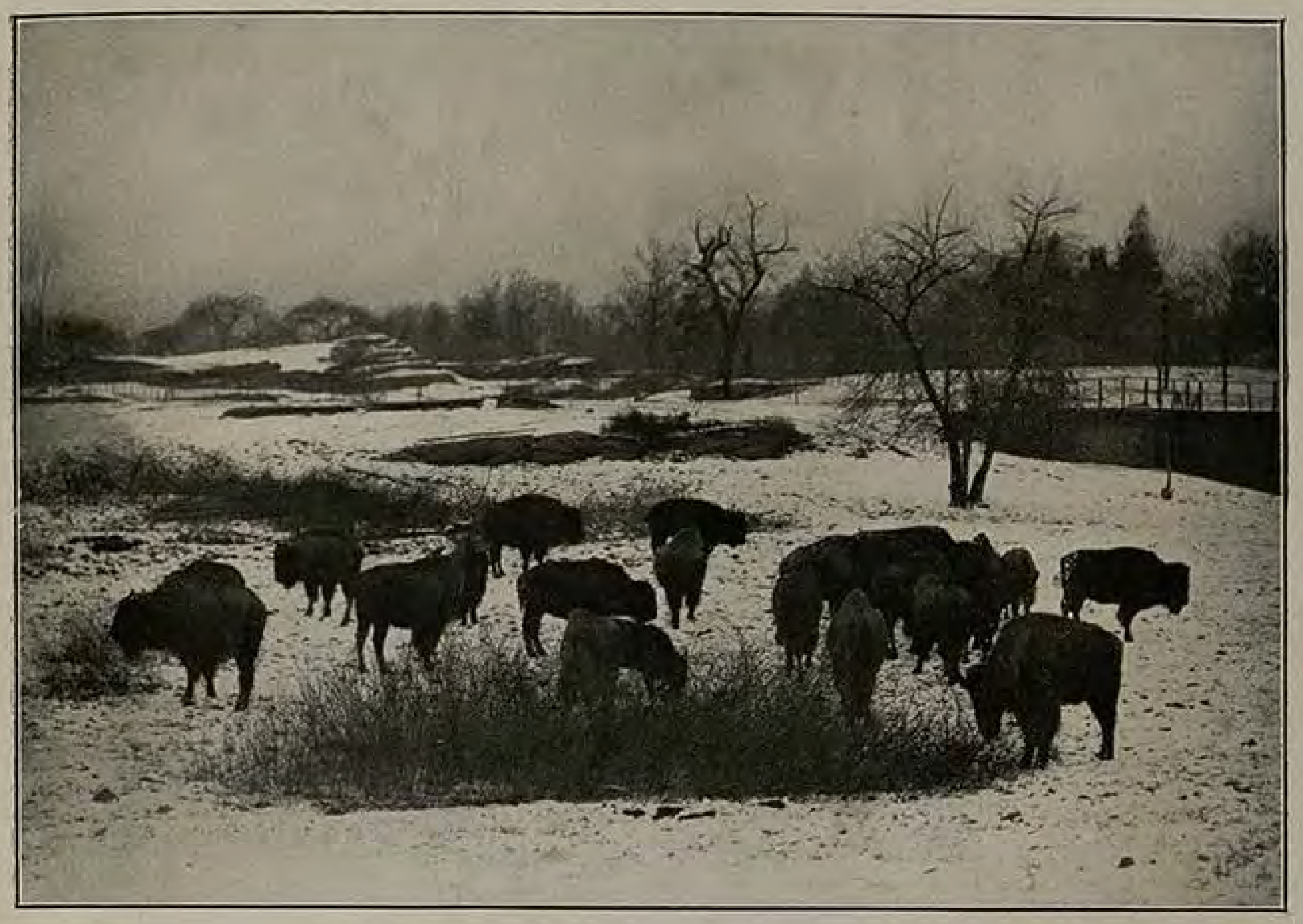

THE ANIMAL THAT IS PASSING.

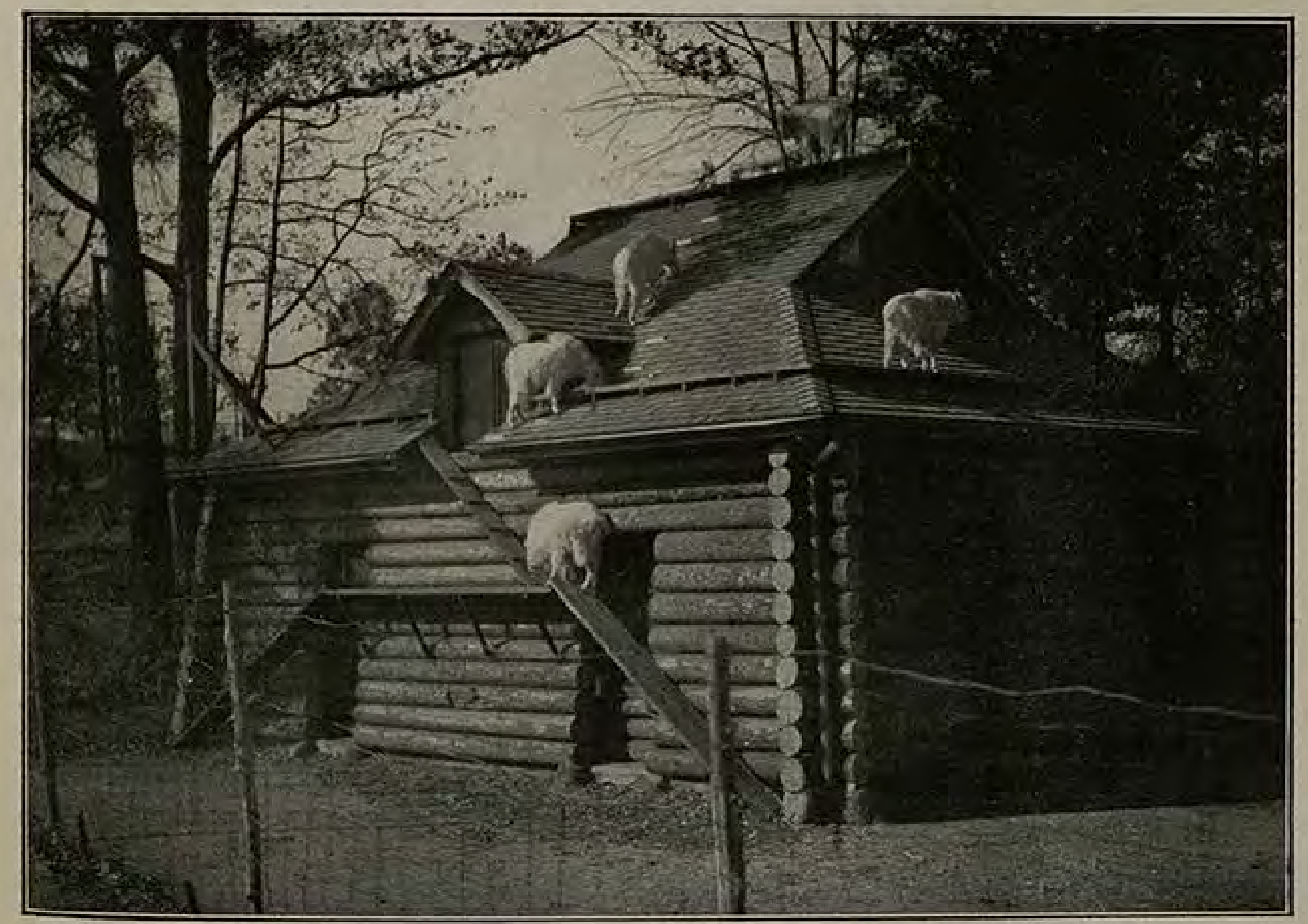

To face page 28.

GOATS :AT BRONX. 
said all that there is to say in the science of forming out-door menageries.

The subway transports the citizen from the crowded hives of the Bowery to a very passable imitation of virgin nature-whatever virgin nature may mean -as it was in the age that preceded the extermination of the wild bison. A herd of those magnificent beasts engages the eye as soon as the gates are passed. They are seen grazing on a wild range. A little further on, the visitor comes within gunshot of a splendid ibex at gaze on the brow of a hill, or on a family of bears playing among trunks and boulders. The secret of Bronx lies in the cunning with which its architects have juggled with perspective and conjured with middle distance, editing wild nature to suit the requirements of captive animals in an open-air home, editing it moreover so cautiously that only the practical eye can tell the raw material from the work of man. Here, two, are the little Rocky Mountain goats, which $\mathrm{Mr}$ Hornaday himself brought back from their mountain homes, and about the tracking of which he has recently published a very enjoyable book. ${ }^{1}$

It is clear-and we may own as much without any disparagement of those who have worked at home under different conditions-that those who have at Bronx produced illusions agreeable at once to the beasts and to those who watch them have owed no allegiance to Old World ideals of zoological architecture. For the realisation of their dreams these fortunate enthusiasts were allotted a vast

'Camp Fires in the Canadian Rockies. By W. T. Hornaday. Illust., with Photographs. London: T. Werner Laurie, 1906. 


\section{FLORIDA AND THE WEST INDIES 29}

space that dwarfs the dole of suburban freehold deemed sufficient in cities on our side of the Atlantic. In our sense of the word, there is hardly any $Z_{00}$ at Bronx. There is, on the other hand, a large mixed family of wild creatures revelling in the open-air life, enjoying great measure of their natural existence amid congenial surroundings, with none of the risks. Here, in fact, is attainment of the ideal, hitherto regarded as Utopian, and rightly so, in more crowded countries, for which $\mathrm{Mr}$ Edmund Selous did arduous battle in the columns of the Saturday Revierv. The picture he used to draw of such a Liberty Hall was a bright one, but no brighter than may be seen any fine day at Bronx, where captivity recalls the verses of the Cavalier poet, being in great measure no captivity at all. A little later in my travels I visited the model estate of Biltmore, where one of the Vanderbilts has proved that, with a few millions at your back, small farming can be carried on at a profit. It would be impossible to have reached such results at Bronx without very generous expenditure, though all the wealth of Golconda (whatever that may amount to) would have been barren without the guiding genius of the Director and the loyal support of his colleagues. Time only is grudged by those anxious for completion. Time generally is grudged by our breathless friends across the ocean. Yet, with such funds at their disposal, the authorities can all but work miracles at a moment's notice. Millionaires dip their hands in their pocket to endow the park as light-heartedly as they would to smash a Trust.

The change that has come over Bronx within 
the last few years is accounted marvellous. A moving peat bog stood where seals now gambol in a pond. Two or three thousand feet of welldrained deer ranges, crowned with an intermittent fringe of oak and cedar, top the summits of granite ridges that still show the chastening hand of glacial action. Back of all is a wild forest scene of oak, maple and cedar, the wood and foliage of which screen the great city that stretches to the very margin of the park and frame gleaming lakes, the home of mallard and white-fronted geese. Some of the birds are not even pinioned. On all sides is such evidence of the joy of life as I know nothing like in any other menagerie. In Old World zoos, many of them, like our own, excellent as far as they go, indoor accommodation is of the first importance. At every turn bricks and mortar meet the eye, and the open-air life is enjoyed only here and there in some small paddock or annexe as a rare change from the dungeons. Impatience of such incarceration has lately manifested itself at Dublin, where the lions are now kept out of doors all the year round, with capital results in the increase of stock, for which the Irish Zoo has always been noted. In most European Zoos such confined hospitality is enjoined alike by the climate, which brings an element of risk into all attempts at acclimatising exotic forms, and by the existence of vested rights of land tenure, which preclude encroachment on the vicinity by so much as an acre.

At Bronx, on the other hand, the permanent buildings are the least impressive feature. If a humble admirer of their present success may offer a word of counsel to the authorities, it is that they 


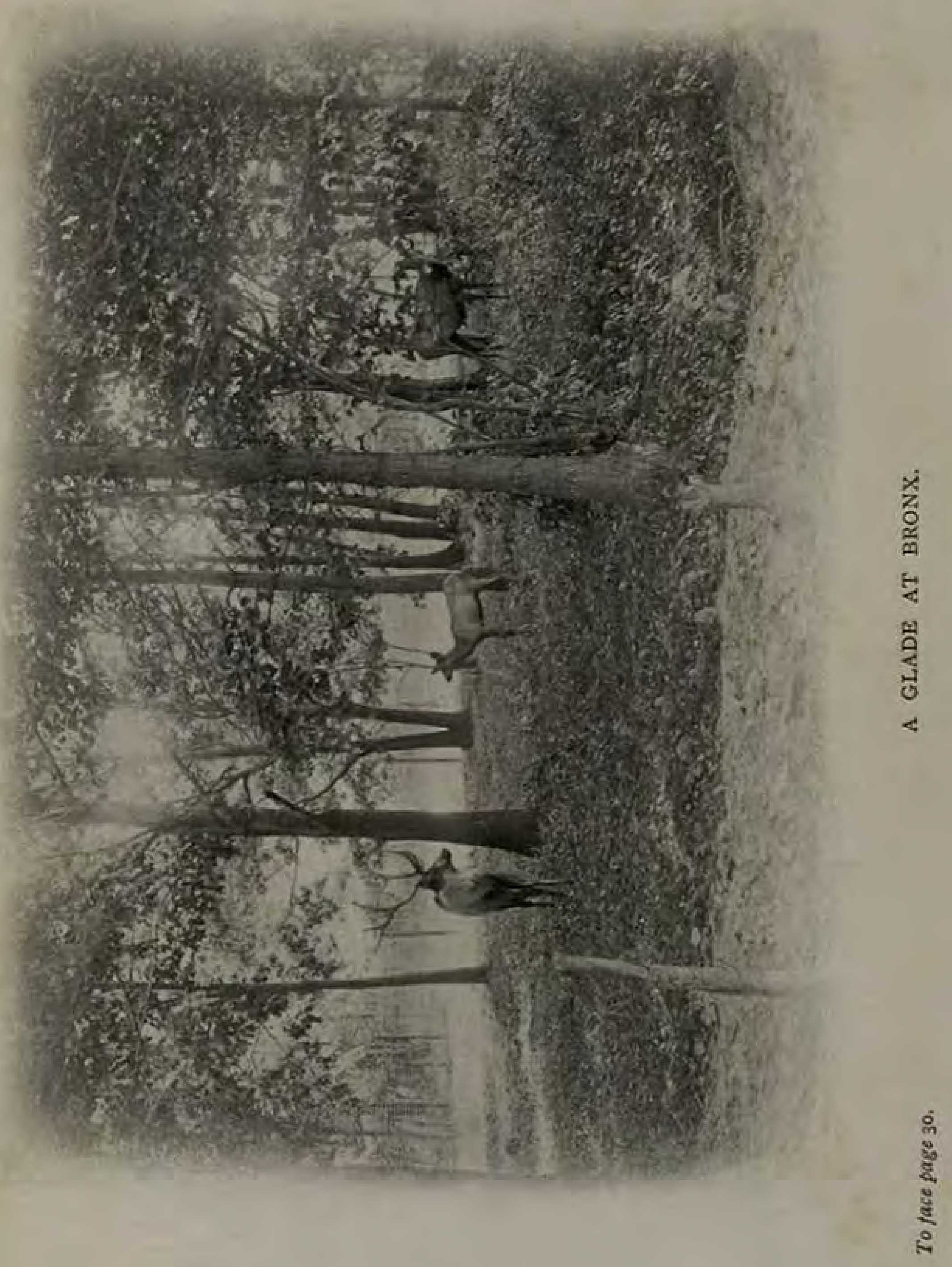


will continue in the future to subordinate bricks and mortar to open air, and turn a deaf ear to those exhortations that are almost certain to be voiced in an atmosphere infected with the skyscraping bacillus. They will no doubt be asked to spend bequests from wealthy patrons in erecting mansions that shall rival the pride of Madison Square. Palaces will be proposed for the lions, villas for the monkeys; but I hope that they will resist all such appeals. So far, the buildings, it may as well be confessed, do not offend by their magnificence. The most stupendous of them all, the great Flying Cage, is less a building than a modified open-air playground, a mammoth aviary that encloses trees and a lake a hundred feet in length, the delight of the crimson flamingo and ponderous pelican, of vultures and of many smaller fowl, all disporting themselves after their own fashion within the almost invisible wire fence. The Flying Cage is superb, dwarfing all ordinary conceptions of an aviary as the flat-iron building on Fifth Avenue dwarfs the mud hovels of Connemara.

In a climate like that of Malebolge, only damper, a value is assumed by permanent buildings that would be lacking under drier conditions. That our Reptile House in London is of heavier design than that at Bronx is therefore as it should be. I am not sure that, thanks to their bath of direct sunlight during the long New York summer, the alligators do not flourish rather better at Bronx than in the majority of Zoos, and the characteristically native groups of rattlesnakes and moccasins are certainly better represented, as might be expected, than in our collection at home. The Lion 
House is also, I think, in some respects inferior to our own, on which, however, it shows a practical improvement in the shape of wire netting, which replaces the old-fashioned bars. This netting, which has a guaranteed breaking tension suffciently high to remove all cause of alarm, does less than bars to impede the visitor's view of the magnificent captives, for which it is also probably more comfortable, since they cannot injure themselves against it as they do by constant contact with bars. There is also a well-lighted studio, in which, with the aid of a specially designed cage, students can work from the living model. On the whole, the big cats have done well at Bronx, and I heard of only one tragedy enacted within its walls, when the jaguar, a dour-looking brute, assassinated a female provided to enliven his solitude, giving her so tremendous a bite as to drive splinters of her skull through the windpipe. In the Monkey House there is a freer circulation of air than is permitted in other Zoos, and $\mathrm{Mr}$ Hornaday assured me that to this generous ventilation he attributes the low death-rate among these usually delicate animals, so often the victims of phthisis. Epidemics are rare at Bronx, though a mysterious malady, never satisfactorily diagnosed, carried off most of the Californian sea-lions one mild week in the winter, and, curiously enough, the native deer are found to be more susceptible to disease in captivity than those imported from Asia.

I was glad to congratulate the Director on the comparative absence of that silly habit of feeding the animals, the ruin of many animals in our Zoo at home. As recently as August, 1906, a fine bear 


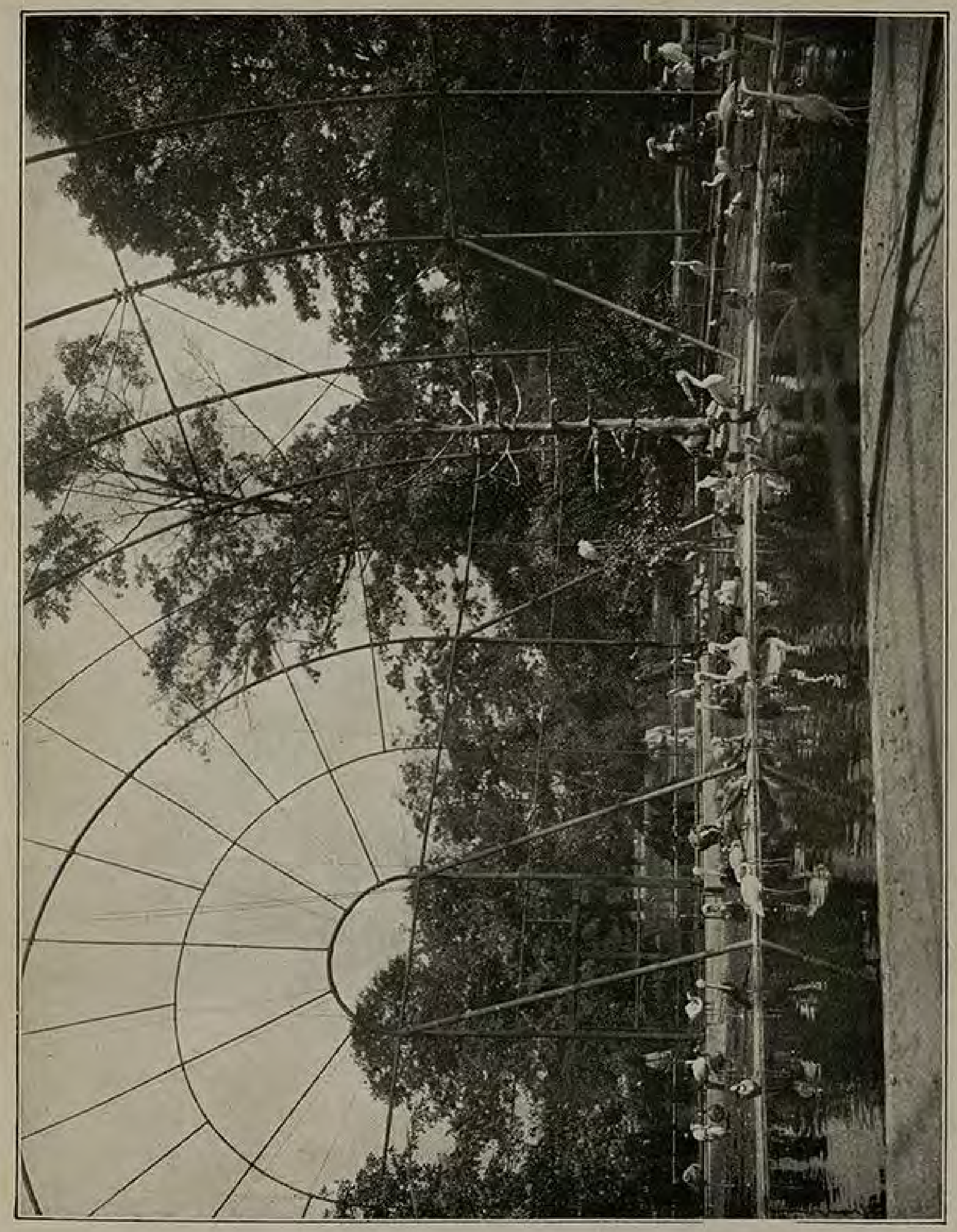

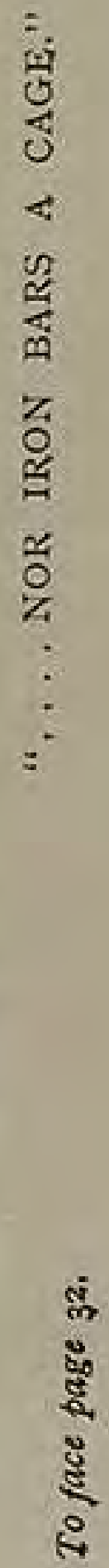




\section{FLORIDA AND THE WEST INDIES}

was lost in this way at Regent's Park, the victim of its own greed and the indiscriminate attentions of the crowd. A prohibition of such senseless bounty should be posted, and enforced, in every menagerie.

What in another five years will be the ultimate success of this already wonderful animal park, which lies between Pelham Avenue and East I 82 nd Street, close to the West Farms terminus of the subway, it is not easy to foretell, but I wish I might see it then. Something will, in the meanwhile, be done in the way of serious literature, which should crystallise around the excellent research work of the medical staff in charge of New York's most interesting family outside the Four Hundred. Up to the present, the official literature has been popular rather than academic, though $\mathrm{Mr}$ Hornaday's hunting experiences and Mr Sanborn's photographs combine to make the Guide more attractive than the majority of such publications, and the periodic Bulletins convey useful and interesting information in popular fashion. The Committee has yet, however, to make some attempt to produce scientific publications like those published by the Zoological Society of London. Our American friends at Bronx know well that such literary traditions do not take root in a day, and they never fail to refer to our Transactions and Proceedings in terms of cordial admiration.

The Zoological Park is free to the public during most of the week, and it would be yet more popular than it is with New York's millions but for the distance which separates it from the Bowery and 
its hordes, to whom even a five-cent fare is a deterrent. Were it a couple of miles farther "down town," not even its vast spaces would save the animals from the risk of suffocation by the crowd of their admirers. The Aquarium, which lies within a short stroll of New York's most populous quarter, and admits the public free of charge save on Monday morning, draws its average of four or five thousand visitors daily, and during the first eight years of its existence no fewer than thirteen and a quarter millions passed the gates. It says a good deal for the behaviour of the New York crowd that never, since its opening, has there been a single cause for serious complaint. We read in the papers of hooliganism in that city, but it is to be hoped that equally satisfactory results would attend the same policy in England, where we have no free show of living animals, the furthest step in that direction being the recent not wholly successful experiment of the Zoological Society instituting sixpenny Saturdays during the summer.

No useful purpose can be served by comparing the menageries of London and New York to the advantage or detriment of either. Conditions, easy in the American city, would be impossible in the English. Neither the Treasury nor the London County Council have offered the support guaranteed to Bronx by New York, nor, in all human probability, would the Zoological Society see its way to accept such a subsidy on the conditions that would be stipulated. If the British nation should desire to endow a menagerie, it is free to do so, but one that is owned by a private Society is also free to charge 


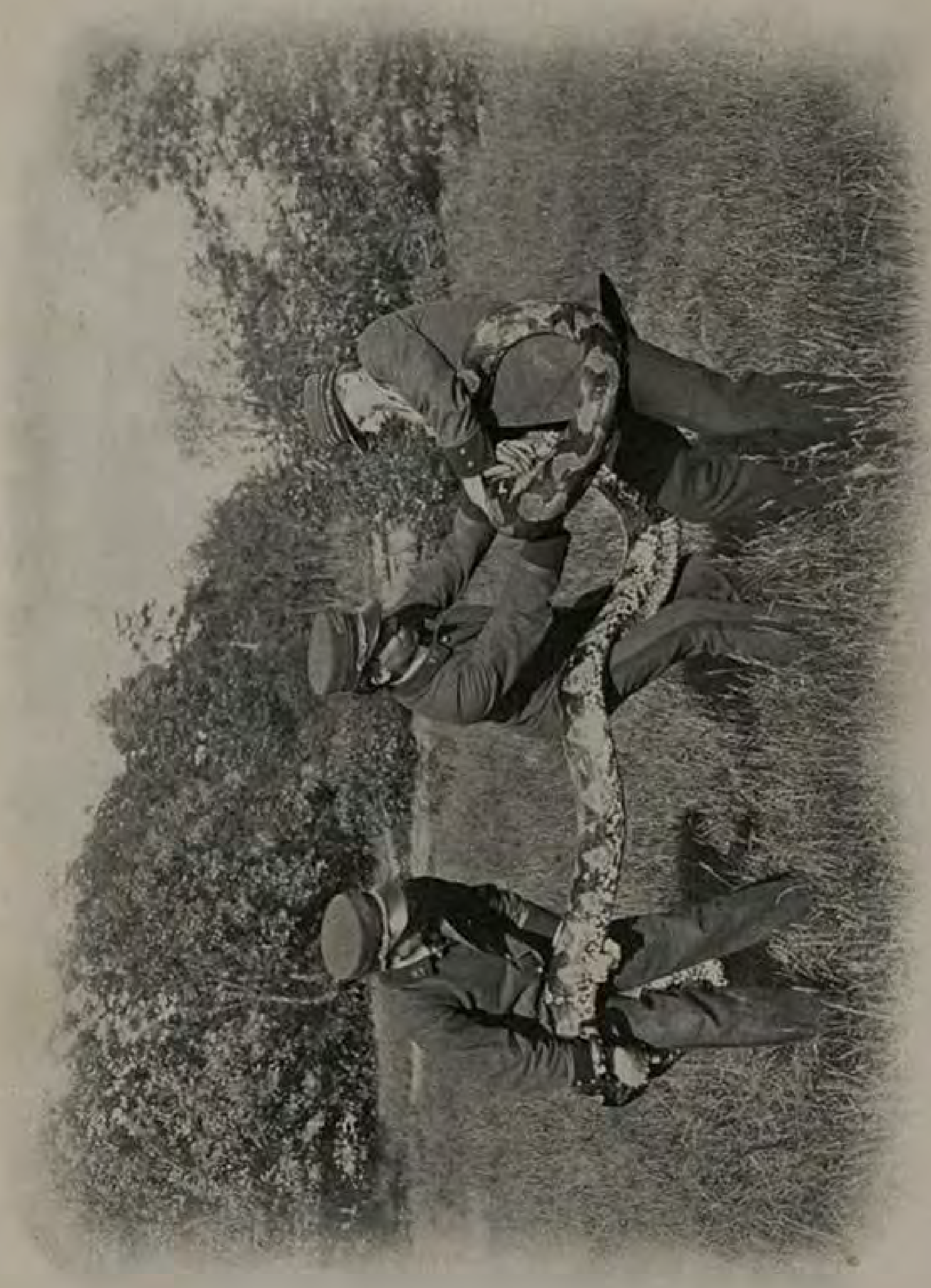

붕 


\section{FLORIDA AND THE WEST INDIES}

for admission within its gates. As regards space, New York has obviously the advantage of having expropriated territory for so admirable a purpose before vested interests and the tyranny of real estate had set their mark on every rod of land. Similar expansion in the north - west suburb of London, save, perhaps, along the sloping, sodden banks of the canal, would be out of the question.

Like the Bronx Zoological Park, the New York Aquarium owes much of its success to the enthusiasm of its Director and the depth of its pocket. A popular aquarium, unaided by side-shows and the evanescent attractions of ladies best appreciated in the dim, religious light reflected from the tanks, has never proved a success in England. One of the largest has passed into the hands of a religious body which relies for some of its popularity on dramatic display; one of the most historic, acquired by a municipal council, has long been insolvent and is a serious burden on the ratepayers. I am by no means sure that the experiment would succeed any better in America. Fortunately, the aquarium located in the old fort, not far from the Cunard wharf, has other sources of income and can afford to throw open its doors to all free of charge. No logical comparison can be instituted therefore between it and those at home, which makes it easy to praise the one without disparaging the rest. To myself, familiar with the establishments at Plymouth, Naples, Melbourne and other towns, the wonderful collections in the New York tanks came as an unexpected treat. I had been adjured before leaving home to think great things of Bronx, and 
my friend, Dr Chalmers Mitchell, Secretary to the Zoological Society of London, had assured me that I might anticipate a very enjoyable day there, a promise that was amply fulfilled. Of the aquarium, on the other hand, I heard nothing until Dr Shufeldt, a distinguished writer on natural history and other subjects, took me to see its wonders. The round shell of the old fort has been transformed into a very paradise for fishes and other coldblooded creatures, like turtles, seals and alligators, all of which are made welcome, from manatees to the larvæ of mosquitoes. In addition to the usual series of tanks round the walls, which line both gallery and ground floor, great pools have been built into the central pavement to accommodate large sharks, sturgeons, drumfish, tarpon and other monsters, of which the visitor is thereby enabled to get a better view than would be possible in the wall tanks, since the fishes have no opportunity of hiding from the public eye.

To argue the Aquarium not susceptible of improvement would be to go much further than $\mathrm{Mr}$ Townsend himself, for he is ambitious of reform in more than one direction, and even contemplates early removal to a more spacious building.

At the time of my visit, to mention only one imperfection, I noticed that the water in the tanks was very muddy, a condition, in all probability, prejudicial to the health of the fishes, and certainly disagreeable to the spectator. $\mathrm{Mr}$ Townsend informed me that this was the result of the recent heavy rains, but that a new installation of pure water storage was nearing completion. The 


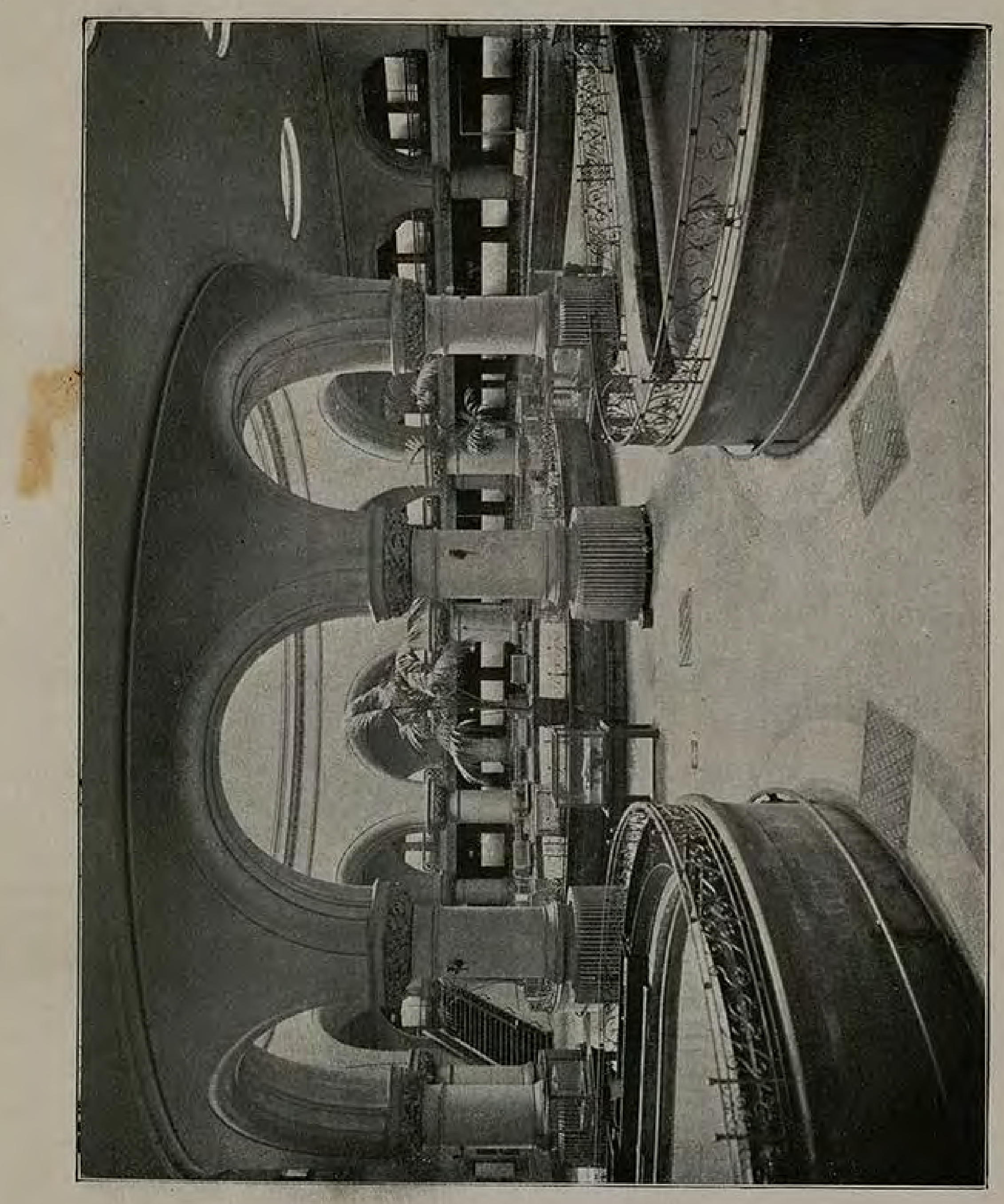

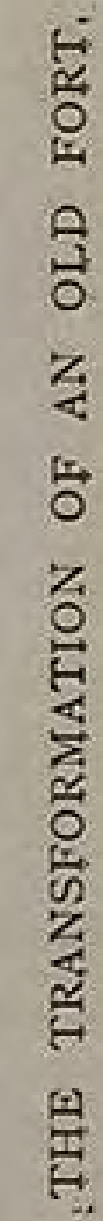

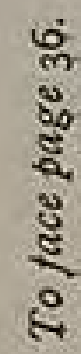




\section{FLORIDA AND THE WEST INDIES}

Director, a younger man than $\mathrm{Mr}$ Hornaday, whom he has taken for his model in his administrative work, had considerable experience with seals and other marine creatures when engaged on work connected with the Behring Sea arbitration, and this special knowledge is doubtless of great use in the discharge of his present duties.

The maintenance of varied and healthy stock in the tanks is his first care. There must be no rari nantes, but abundance and variety of forms, and nothing is neglected that conduces towards good condition in the fishes, though the wild stories that have reached the press of his remarkable operations on diseased inmates of the establishment have no foundation. When a fish is dying, the best way is to knock it on the head and get another, and in this policy the Director fully concurs. The fishes in aquarium tanks are peculiarly liable to epidemics, particularly when impurities find their way into water which circulates through the whole system. Now and then the inmates give trouble, even though not actually ill. In one case a sea-lion, that was sent from Bronx, barked so loudly night and day that, tired of sleepless nights, the Director ordered its keeper to give the animal increasing rations of fish "until it quit barking or bust." Fortunately, the patient preferred silence to rupture, but ever since its orgy it has plunged wildly about its tank, perhaps to cool its overheated blood.

Besides looking after the health of the fishes, the Director is constantly engaged in studying the latest improvements in lighting and labelling the tanks, providing them with suitable backgrounds and filling in unused spaces with palms and decorative 
shrubs. The task of lighting the interior of a building originally constructed a century ago, with walls ten feet thick to resist the round shot of hostile warships, could not have been an easy one. The difficulty was overcome by the installation of large skylights. Very attractive effects have been obtained by lining the salt-water tanks with coral rock specially obtained from the Bahamas, and those containing fresh-water fishes with river gravel. These backgrounds, rendered still truer to nature by the addition of suitable aquatic plants, are a vast improvement on the old-fashioned white tiles, and enhance the beauty of water-pictures that recall the submarine tableaux dimly seen through the water telescope. Apart from such merely spectacular advantages, they contribute to the health and comfort of the fishes themselves. The result is to reproduce under water the natural effects that go so far to soften the harshness of captivity at Bronx. Unreserved praise must be bestowed on the way in which $\mathrm{Mr}$ Townsend has labelled the tanks. In the ordinary aquarium, the authorities are content with giving the trivial and scientific names of each fish. At New York, an attempt is made to anticipate the questions likely to be put by intelligent visitors, and something is said of the geographical range and particular haunts, the habits, market value, importance to the angler and such details. Each label bears an accurate portrait of the fish, indispensable in cases in which several kinds share the same tank. The letterpress in which this information is conveyed is printed in bold type on oiled paper, which forms a transparency between sheets of glass, legible at some 
later I brought the question of its utility to the notice of Colonel Gorgas, the eminent authority on tropical diseases in charge of sanitary operations of great magnitude on the Isthmus of Panama. For answer, he pointed to some stagnant ponds in the vicinity of the Culebra Cut, and in each of these was a company of little fishes, all of which, he thinks, devour the larvæ of these vehicles of disease. Thus may Nature set the antidote beside the poison.

Those who know something of the difficulties attendant on the management of captive fishes will appreciate the fact of some of the specimens having flourished in the Aquarium for more than ten years. The truth is that a fish in an aquarium is something like a cricketer-once set, there is no knowing how long it will remain in. Good work has also been done here in the hatching of trout, millions of which have been handed over to the Fish Commission for free distribution in suitable waters throughout the country. So rich in marine forms are the twenty thousand miles of sea and lake coast in that vast territory that anything in the nature of a representative collection from even the two seaboards could not be housed in one aquarium. As a matter of fact, the Atlantic side contributes far more generously than the Pacific, and the deep water round Bermuda and the Bahamas, doubtless because so much more accessible by steamer from New York, has been drawn on much more liberally than even the bays of Florida.

The restfulness of one day at Bronx and another at the Aquarium made a pleasant change from the 


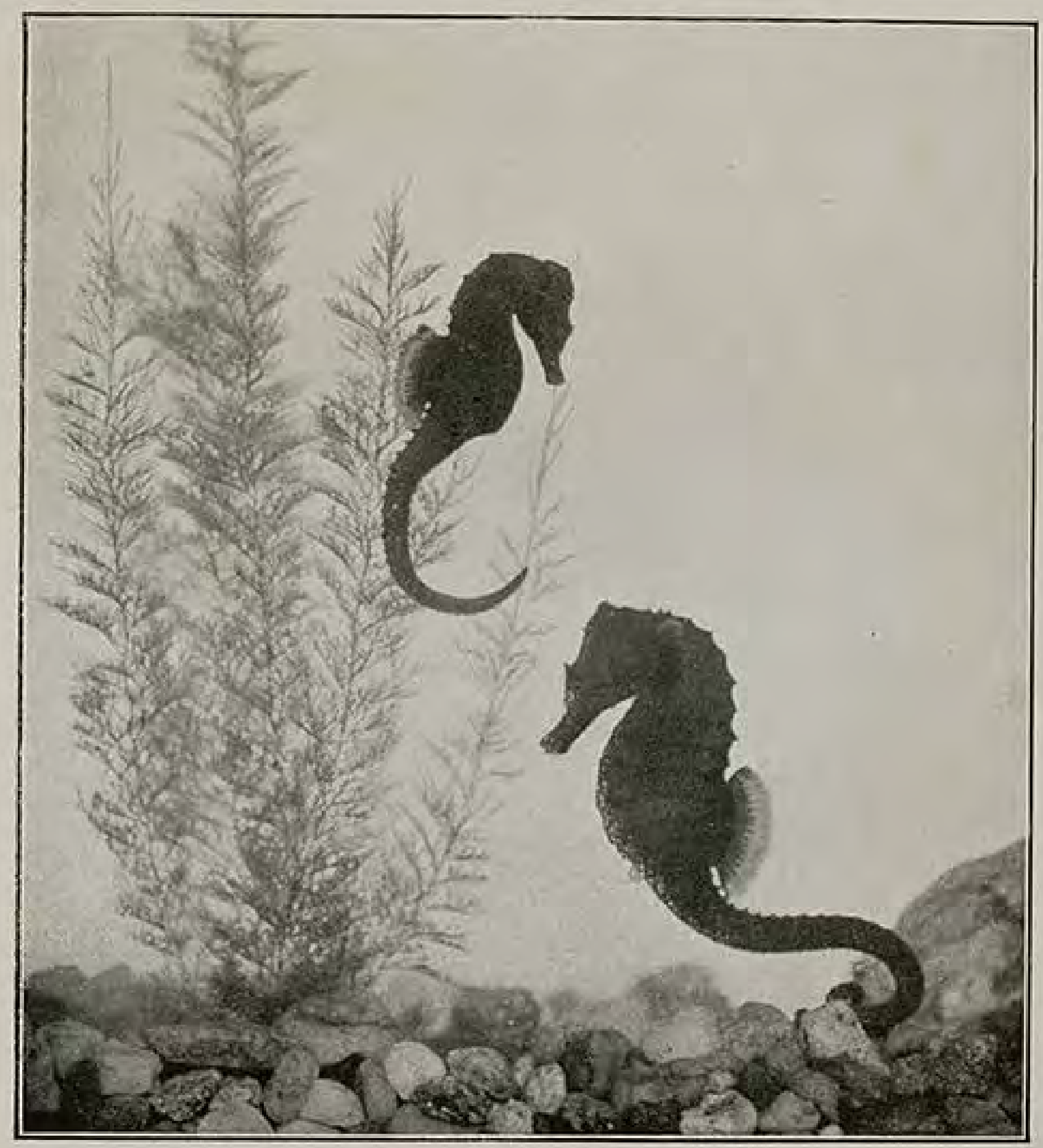

SEA HORSES.

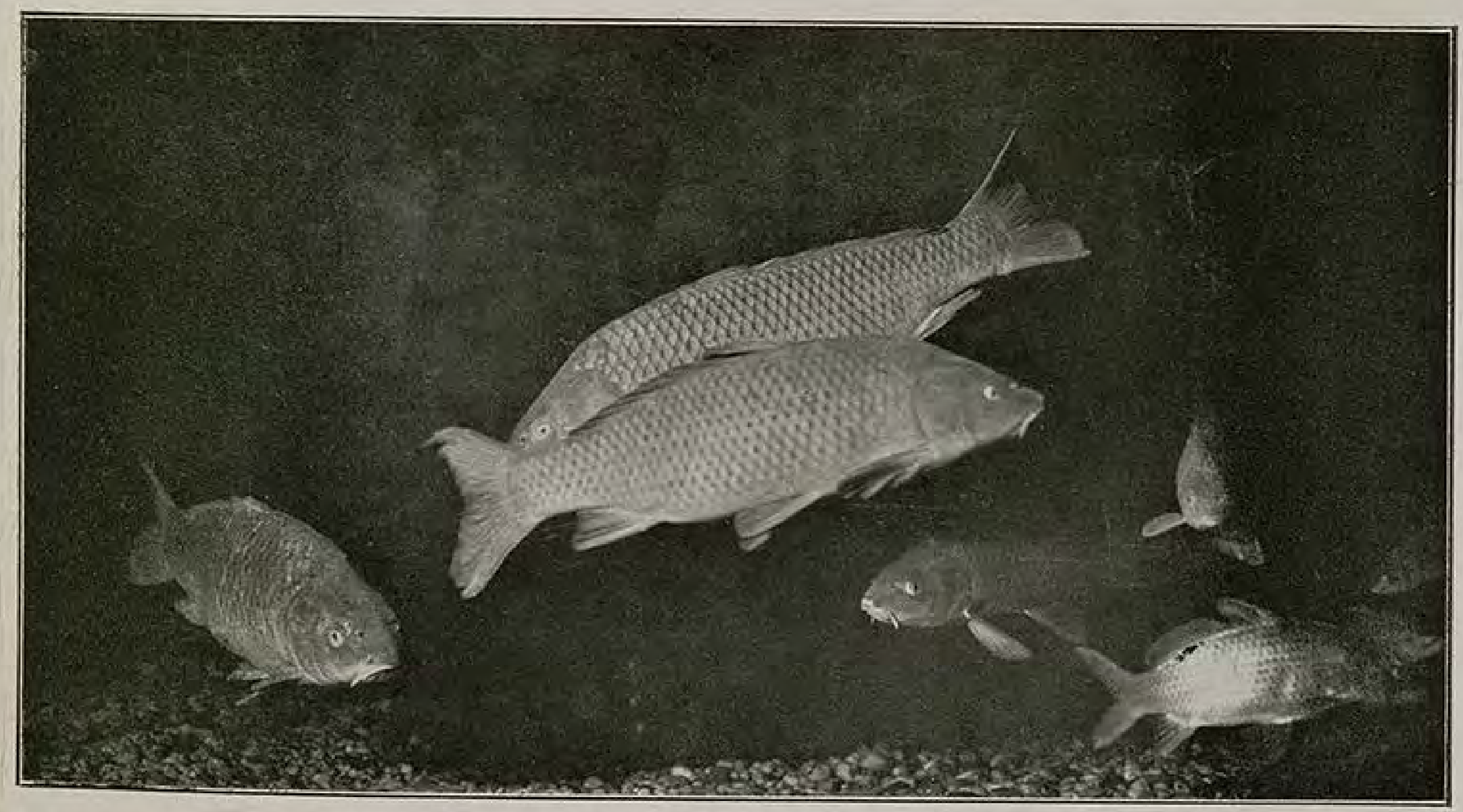

To race page 40.

THE SILENT INMATES OF THE TANKS. 


\section{FLORIDA AND THE WEST INDIES 4I}

hustle of the wonderful, overcrowded city, in which the exclusive of the Four Hundred live cheek by jowl with the abusive of the Bowery, and where the tinfoil trumpery of the drinking saloons in the Tenderloin quarter can be seen by the aloof occupants of the carriages that bowl along Broadway.

The Englishman who spends even a month in that land of liberty, equality and fraternity, will, unless I am much mistaken, arrive at some strange conclusions touching these Republican ideals. Liberty! Without one unkind thought of a city that gave me of its hospitality, I venture to suggest that there is in one hour of London more personal liberty than in a year of New York. I have been on a New York street car that took its full complement of passengers before starting. Then, without one word of protest from either these or the conductor, as many more have boarded it within the next half mile, most of them such "very imperfect ablutioners" as to offer no attraction whatever when it is a question of dandling them on your knee. These things, after all, are a matter of custom. When a very large and hot bricklayer sat, without so much as "by your leave," on my knee, I contrived, as I was on the outside seat, to drop him in the road by a sudden straightening of the rightleg. The car was only just moving, and no one was aware that he had left it otherwise than voluntarily. When he got on his feet again he had, no doubt, only the merest bruise as a reminder of his unsuccessful raid on foreign territory. Had he broken his back, I should probably have been driven by remorse to look after him, but I saw him walk after the next car without a limp. That is 
New York's idea of liberty. Thanks be to God (and the City Police), we in London are slaves!

Equality! Yes, I can recall a case of equality at Washington. While staying at the New Willard, an admirable hostelry, the day after my encounter on the street car, I scratched my cheek on a pin that stuck upright in my pillow. Ringing next morning for the chambermaid that I might give brief and soulful information on the difference between a pillow and a pin-cushion, I showed her a long and angry mark on my face. She might, perhaps, have apologised, but she did not. Instead, she hailed another servant employed on the same corridor, and, putting her forefinger to the wound, said, in a voice devoid of compassion and suggestive, rather, of the unemotional curiosity of a Sunday visitor at the Natural History Museum, "Just look at this man's face!" There are moments when to be called a man conveys a compliment; there are other moments when it does not. Anyhow, that is Washington's idea of equality. Long live the editor of Debrett! We at home are unequal. Long may we remain so! It is best.

Fraternity! I once saw a cargo of brotherly Republicans hustle their fellows off a gangway and into the water without troubling to see whether they swam or sank. We at home are cold, not brotherly, but we do not shove fellow-creatures into the possibility of sudden death without a qualm.

I was asked during my brief stay in New York how I liked it. I was asked, perhaps, a score of times. One gentleman connected with the press even interviewed me on the subject before I was 
off the ship. With what brutal indifference do we of London view the opinion of foreigners! But, then, the grandfathers of the present generation made New York; the responsibility for the other city is too remote to allow of personal stake in the result.

In a community where the stress of competition is a creed-even American angels probably scorch on the wing in the upper ether-there is a degree of rivalry among the cities quite unknown in older countries. Several amusing anecdotes bear on this jealousy that one city has of another. In one of these, a Boston man is supposed to have wagered a friend from Chicago that he would tell the bigger lie. The Chicago man started with his contribution.

"I once," he commenced, "met a gentleman from Chicago" -

"Hold on," interrupted the other, "from where, did you say?"

"Why, from Chicago"-

"Done!" was the retort; "I pay."

At the time of the World's Fair, when the receipts were not quite up to expectations, a Cincinnati paper remarked-

"It is surely impossible that Oliver Goldsmith can have had St Louis in mind when he wrote 'The Deserted Village." "

And the busy men of New York hold those of quieter cities in fine contempt. Philadelphians, they say, come to no harm even if they fall off a roof. They don't fall fast enough.

My stay in New York terminated with an 
unpleasant experience, for which I had only myself to thank. Before I left England, my banker in Devonshire had impressed on me the convenience of letters of credit, but, spoilt perhaps by the former kindness of friends abroad, I anticipated no difficulty in cashing cheques whenever the occasion might arise. I therefore rejected his wise counsel, but hope that none who read this will do likewise, for the result is both disagreeable and expensive. The cashier at my hotel on Fifth Avenue politely but firmly declined to accept a cheque in settlement of my account. Though exceedingly wroth at the time, I have, on reflection, realised that his objection was perfectly correct. All men are liars, even fishermen, and there was nothing to satisfy him that my bank account was in order. For myself, the annoyance of the episode was aggravated by the fact that I was timed to leave for Washington in an hour, and, of all days in the week, of course it was a Saturday, so that, allowing for the difference in time, the bank was already closed. Consequently, the cable which I despatched at once for remittance by wire would be inoperative for forty-eight hours. Fortunately, I had just enough to pay my bill, send my cable and get to Washington, after which there remained to me the princely balance of a dollar and a half, otherwise six shillings sterling. Even on the Monday evening, when help eventually arrived by way of the submarine cable and a Washington bank, I had no little difficulty, owing to the combined need and impossibility of identification, in obtaining possession of my own money. Not until I had produced miscellaneous evidence that $I$ was $I$, in the shape 


\section{FLORIDA AND THE WEST INDIES 45}

of letters, cards, a passport, and inscriptions in my watch and on my cane, did the president of the bank finally consent to liquidate my claim on him. I told him that the only chance of identifying me was to walk over to the White House, where I had that morning had an interview with the President. I could not, so near the dinner hour, hold out the prospect of a very warm reception, and that, I think, settled him. When, some weeks later, I told the experience to the Colonial Secretary of Jamaica, Mr Clarence Bourne, he recalled a most amusing case in which someone, who found himself in a similar difficulty, sought in his despair to establish his identity by disclosing the tab of his shirt. With this object he pulled up his waistcoat, thinking to show his own name, when, to his horror, he discovered that a wrong shirt must have been sent from the laundry, for the name on the shirt bore no resemblance to his own. On another occasion, $\mathrm{Mr}$ Bourne himself, having been relieved in a Continental railway train of a pocket-book containing all his loose notes, went to Cook's bureau in one of the cities of northern Italy to see if the manager would cash a cheque to meet his immediate needs. He suggested that a telegram be sent to his banker in London, and said that he would call back later. On his return, the same evening, he found that no answer had been received, but in spite of this, impressed, no doubt, by the readiness with which he gave his banker's address, they cashed his cheque, an act of courtesy grateful to the exile, but too rare to be counted on, so once again I counsel letters of credit. 


\section{III}

WASHINGTON D.C.

RAILROAD travel in the United States is a very different matter from railroad travel in Great Britain. The imperfections of our railway system at home are the constant theme of all who hold no railway shares. One says that they should be nationalised; another that they need to be Americanised. That governments do their work more expensively and less efficiently than private enterprise is the sad conviction of those who take note of such matters, and, as for Americanising our lines, fifteen hundred miles of railroad travel in one week assured me that American methods would completely fail in England. The conditions are wholly different. Our longest journeys at home are so brief, that the run between one terminus and the other would be no more than a stage in America. We feel fatigued after a run of hours; the American spends days and nights on the track. We call ourselves busy, and take what we call express trains. The American tries to arrive before he starts, reckless of risk, feverish to be first in the race. In memory of one or two dreadful railway accidents at home during last year, in one of which a number of Americans were the sufferers, I feel some hesitation in calling attention to the admitted frequency of "wrecks" in that country. The officials are less to blame for this sacrifice of life 
than the public, for the average American business man would cheerfully face the risk of annihilation, but would chafe to go slow. They do what they can to mitigate the chance of collision; and a thousand steel, fireproof, and non-telescoping cars were, since the time of my visit, added to the Pennsylvania rolling stock. It is by the Pennsylvania railroad that you journey to Washington D.C., a quick and comfortable transit through very homely scenery. They are building a tunnel now to connect the city with the other shore, but when I was there it was still necessary to cross by the ferry at the top of 23 rd Street.

Baggage, however, was " checked" to destination without further charge, and, after parting with it at the ferry, I saw no more of it until we reached Washington. In this matter of luggage the practice of the two countries differs widely. The Englishman watches his trunks and bags into the van at starting, and accompanies the porter to the van to recover it on arriving at the end of his journey. In very hot or very cold weather he grumbles at having to do this, but, if matters were arranged otherwise, he would find something else to grumble at. The American traveller, on the other hand, prefers to disclaim all responsibility, hands over his belongings in return for "checks," and expects to find it on the platform when he reaches his goal. Often, no doubt, all goes well, and then the checking system has much to recommend it. But what of the times when something goes wrong? Before I went to the States, American friends used to assure me that nothing ever did go wrong, and that their baggage system worked as 


\section{SUNSHINE AND SPORT IN}

smoothly as the tides. Now I know better, for in my one week of acquaintance with American railroads, two-thirds of my baggage, checked through to Punta Gorda, in Florida, from Jacksonville, was left behind at Lakeland, entailing on me great inconvenience. Americans may think that I romance, but I call to witness the baggage-clerk at Punta Gorda, who took great trouble in helping me recover my own, and who bore undeserved reproaches with a meekness certainly un-American and almost more than human. As very little luggage indeed is allowed on the cars, the conductor objecting to anything more than a "grip" (i.e. portmanteau), there remains to the traveller only the more expensive alternative of sending on his belongings by one or other of the Express Companies.

The immense distances covered in railway journeys in America account for all, or almost all, the difference between travel there and in England. From a glance at its map, I imagine, though I offer the suggestion with reservation, that the Southern Railroad alone uses as much permanent way as all the main lines in England put together. That system, which has its offices in a palace on Pennsylvania Avenue, Washington, took me a thousand miles in a couple of days. It penetrates into districts remote and unpeopled, through thick forest, luxuriant savannah and sandy wilderness. For hundreds of miles the rails push their way through hostile vegetation, or lie on loose sand. So light is the passenger traffic during some portions of the year that it would not pay to build a double track to these outposts of civilisation, and, 
even with efficient signalling, a single track is a fruitful source of collision. On the far western tracks, we also read of occasional cases of brigandage. Where these are not the offspring of journalistic brains, fertile in picturesque copy, they are the inevitable result of the difficulty of adequately policing these sparsely-inhabited regions, as well as of the cheapness in that country of accurate firearms and poisonous whisky.

The difference on the railroads most likely to impress the Englishman is in the vernacular. We have recently been informed by our good friends in the West that we do not know how to spell English, but an hour on one of their railroads should suffice to impress on us that we do not even know how to speak it. When is a station not a station? When it is a depot, with a strong accent on the $e$. Similarly, in that enlightened country, luggage is baggage, trunks are grips, clerks are operators, carriages are cars, accommodation is reservation; everything is something else. In the best trains, there is a high degree of comfort, almost luxury, to which we at home are unaccustomed. The "Congressional Limited," on which I travelled from New York to Washington, is one of these. The fares are, on the whole, lower than at home; indeed, so immense are the distances that, if they were not, few could afford to travel at all. In the fittings of the cars, and also in the excellent dinner served in transit for a dollar (only eightpence more than they charge at home for an assortment of tepid garbage), this "Congressional Limited" is a little better than our best, and I believe that it is not by any D 
means the most luxurious train in that country. The "Observation Car" at the back, where a few can sit and look, as from a balcony, at the receding track, without, for some unknown reason, being permitted to smoke, is an excellent addition that would be welcome on our Scotch trains at home.

On this particular run to Washington, the scenery could well be spared, and the inside of the car is more pleasing to the eye than the surrounding landscape. One effect only-a sunset on the Delaware river-was worth remembering. As for bird life, for which I always keep a sharp lookout, I saw no more than a couple of seagulls near Baltimore, and when we stopped at that station, my thoughts flew to the untasted terrapin for which, in season, that city is justly famous, as well as to the memory of having somewhere read that the first blood shed in the war was that of a Massachusetts man shot in its main street. So, also, when we had pulled up at Philadelphia, I wondered over what abstruse volume my young friend of the Caronia might even then be poring.

I kept resolutely to the train, however, although I had been adjured to break the journey at Baltimore and see the prettiest girls in America. Not St Anthony himself could have been firmer. It was dark when I reached Washington, and I went straight to my hotel and to bed. Next morning, in the lucid intervals of a dull, wet Sunday, I wandered among the elegant avenues of the political focus of American thought, and everywhere I saw signs that here was the intellectual capital of the country. New York convinces you of America's 


\section{FLORIDA AND THE WEST INDIES 5I}

wealth; Washington of her greatness. Here is a degree of stately elegance undreamt of in the city on the Hudson. No one pushes you off the sidewalk. There are open spaces, empty streets. Trees have room to grow and spread their welcome shade over the city's arteries. From White House to Capitol stretches a broad ribbon of white and green-Pennsylvania Avenue. The gleaming Potomac glides past a lovely city in which the American nation is, to use its own favourite expression, making good. Farther north you realise the breathless battle of the dollar, the strenuous struggle of the Trust, the buzzing amphitheatre which witnesses the death-throes of millionaire gladiators in the net of speculation. Washington reveals rather the soothing splendour of a past, the brotherhood of nations, the glory of a good fight fought for the honour of a great nation, which is something higher than gold or oil.

The one episode of my brief stay in the capital was a meeting with the President, one of the two ambitions that took me across the ocean. On calm reflection, I believe that I even put the privilege of shaking hands with $\mathrm{Mr}$ Roosevelt higher than catching a tarpon of anything less than three hundred pounds. He had for years made strong appeal to my imagination as both statesman and sportsman, a combination dear to all who have a kind thought for Derby, Palmerston, and other great names of the past. Was ever such another man of Destiny? The term has been loosely applied to those that have played a greater part in the world's history, but it fits with peculiar appropriateness the man whose rivals made him Vice- 
association that I had never dreamt could have lingered in a mind occupied in making and unmaking history. Shooting and fishing we talked, rifles, brook trout, sea-fishing, and similar light topics. No doubt, most of $\mathrm{Mr}$ Roosevelt's visitors engage him on more serious subjects, but I doubt whether he can always be grateful for it. He inquired cordially after several sportsmen at home, after Lord Desborough, whom he had known as "Willie Grenfell," a quarter of a century earlier in the Rockies, and after F. C. Selous, for whom he evidently entertains the warmest admiration. He confessed, albeit no enthusiastic fisherman, a preference for the wild brook trout, regarding the larger rainbow as a less sporting fish, and he told me of a most interesting case of brook trout, usually puny fish, exceeding their average dimensions somewhere (if I remember right) in the State of Maine, owing to natural conditions that fish-culturists had hitherto failed to diagnose. Another subject that interested him was the complete lack of woodcraft in the average English sportsman out from home, as contrasted with the intuitive rough-and-ready lore that enables the American to find his way out of the deepest jungle, and to ward off starvation with the most slender resources. I suggested that our sport at home, if less educational in these elementary virtues, is at least better suited to the requirements of busy men in need of brief relaxation from the cares of office or from the grinding of the mill. If we lack the charm of virgin Nature, we also get more sport with preserved birds, though big game shooting (unless the semi-artificial sport of deer "forests" be included under that head) is, for 
obvious reasons, impossible in a thickly-populated island with twenty centuries of history behind it. The fatigue of stalking mountain sheep, I reminded him, would not appeal to everyone, and he admitted that there was something in that point of view. Like most sportsmen, the President, though nearing fifty, retains the keenness of a schoolboy. On the morning of my visit, he had received from Europe a gift of a presentation copy of a sporting book written by an Austrian archduke, and he whimsically envied the man who could afford to give the world his autobiography in such sumptuous style. To the terrible disaster at San Francisco he referred in terms that combined the warmest sympathy with a business-like grasp of the best means of help, and even then a long string of relief trains was speeding west. Lastly, we talked of Panama, and in response to a casual remark of mine that I proposed to return by the Royal Mail route and visit the Isthmus, he kindly gave me a letter to Colonel Gorgas, which, in due course, ensured for me a quite unexpected reception in the canal zone. I told him of the anxiety felt at home owing to the possible transmission of yellow fever into Asia by way of the canal, and he suggested, with a humorous allusion to the obsolete advice of Apollo not to drain the Camarina lake to get rid of malaria, that I should go and see for myself the great work that was being done by the sanitary authorities at Panama, which at the appointed time I did.

The President was precisely what I had expected, neither more nor less. I had seen great men before, but they had been invested with the peculiar atmosphere of royalty or military pomp. Here was one 
formalities of tickets granted only on application through householders. I also remember, with misgiving, that only five students were availing themselves of its treasures at the time of my visit, but that, perhaps, was exceptional. I hope so. The Zoological Park also struck me as picturesque, with natural advantages superior, if anything, to those of Bronx, but sadly in need of money. The bears, including some magnificent examples from Alaska, were miserably housed, and so great a rarity as a Steller's sea-lion was cramped in a little tank more fit for goldfish. Australia and New Zealand had evidently contributed more generously, the former to the mammals, the latter to the birds, than they had to Bronx, and Tasmania had sent both "wolf" and "devil" to swell the ugly element in the collection. It seems a pity that America's most beautiful city should not be endowed with an animal park in keeping with the rest. Perhaps some millionaire may yet put his hand in his pocket and remove so obvious a reproach. 


\section{IV}

\section{LAND OF THE SKY}

I LEFT by the Southern Railroad that evening, and passed the night in a luxurious, if muchheated, Pullman car. Postponing my arrival in Florida for a few days, I planned a digression from the main track that I might see the famous Sapphire country, otherwise "Land of the Sky," of North Carolina. I had heard the praises of that region in New York, and the President confirmed this from hearsay, though he had not then visited the district himself. As my itinerary was marked through Florida, which is flat rather than flowery, it seemed desirable to get one glimpse at least of American mountain scenery, if not the much-described Rockies, at anyrate the spurs of the Alleghanies.

Next morning, therefore, I changed trains at a small and ugly station (God rest the man who built it!) on the Carolina border, where a large negress seized my lighter baggage, looking as though she could have seized me as well, and bore it to the other car. My heavier trunks were checked through to Jacksonville, and there I found them three or four days later. In a few minutes, not more than half an hour late by schedule, I found myself zigzagging amid the lovely mountains that frame the Asheville plateau, and enjoying 
from alternate windows the invariable breathless fascination of mountain gradients, with the train doubling on its tracks and revealing at once the hindmost car swinging after the rest and the puffing locomotive rounding a new curve in front. The winding Alpine track was visible at half a dozen points above and below, and the train panted bravely towards the clouds, plunging every few minutes into the blackness of tunnels, only to emerge on a yet more beautiful scene than that so abruptly hidden a moment earlier. Such effects I had known in three other continents-in white memories of Switzerland, in Australia's Blue Mountains, in the highlands of Java, but nowhere, I think, to surpass the pictures on either side as the train went groaning under its brakes back to the drainage area of the bubbling Swannanoa where it runs past Asheville.

That comely health resort which, perched two thousand feet nearer heaven than New York, recalls at once Buxton, Bournemouth and Torquay, has a deserved reputation for patients in the earlier stages of consumption. Spending a day at Asheville, I walked through part of $\mathrm{Mr}$ Vanderbilt's Biltmore estate, which is run on a system at once feudal and benevolent, and a little out of drawing, perhaps, on the Republican canvas of his fatherland, and I admired less his palatial residence than the blaze of rhododendrons and other flowers which ran riot over his broad acres. I was told of a curious little enclave, held by a negro cab-driver with no very clear title to his property-another relic of Abolition. I also visited the horse show, held in a meadow 


\section{FLORIDA AND THE WEST INDIES}

beside the river and reached by one of the prettiest tramcar drives I ever took in any land. At Asheville, one of the most attractive towns on my travels, I heard a curious story, for the truth of which I am unable to vouch. Some years ago, a soi-disant English duke, who claimed close kinship with a well-known statesman of the Liberal party, ran deep into debt and died insolvent in the town. It was then discovered that his dukedom was apocryphal and his relationship to the politician a myth. His body was embalmed for burial, but no money was forthcoming to pay for the job, and they say that it is still on view at the undertaker's store. I made no attempt to view this grisly relic of a luckless impostor, and, for aught I know to the contrary, the whole story may have been a fabrication of the tramcar acquaintance from whom I had it.

The peculiar beauties of travel at high altitudes must inevitably be bought at the price of pace. On those dangerous gradients the brakes are rarely off, and the time schedule is interpreted with latitude, for if mountains no longer bring forth mice, they bring forth "wrecks" when treated carelessly, more especially when the rails are slippery with rain. Therefore, my train, which left Asheville that evening in a downpour, arrived at Lake Toxaway a couple of hours late, in fact only just before midnight. It was a tired and hungry traveller that alighted, but there was reassurance in the fairyland of lights mirrored in the unseen lake and the promise of great beauty with the sunrise. As my plans included a drive of twenty or thirty miles next day, I 
retired to a hot bath and bed directly after supper, leaving open two great windows that I might sleep more soundly bathed in pure, cold mountain air. Next morning I a woke to the glow of sunshine and the song of many birds. The staccato of the whip-poor-will and the more lingering carol of the mocking-bird bade me look out on the lovely lake that stretched its blue and golden mantle round two walls of the inn. Bath and breakfast over, we bowled away in a surrey drawn by a pair of mountain greys that took those turnpike roads as if they trod on air. My companion was $\mathrm{Mr}$ John Burrowes, president of the hotel company, and to his intimate knowledge of the district and of wild life in America generally was owing much of the pleasure of the day's outing.

I have done but very little driving in my time, preferring horseback, or, better still, going on foot with rod or gun. In consequence, I treasure the rare memories of any exceptionally enjoyable jaunt on wheels-of sunset coaching among the tors of Dartmoor, of one lovely excursion in the hills that look down on Hobart, of a drive at daybreak to a meet of otter hounds somewhere near Beaumaris, in the company of the late squire of Vaynol, with whom I was staying at the time. To these, and a few beside, must now be added the memory of that long day in the surrey, skirting the shores of three lakes dotted with boatloads of busy anglers, broken by the rising of trout, and mirroring the flight of wildfowl, and up the side of a mountain, at the summit of which we lunched in the clouds.

$\mathrm{Mr}$ Burrowes seemed to know every tree in every glade. With that curious combination of the artistic 


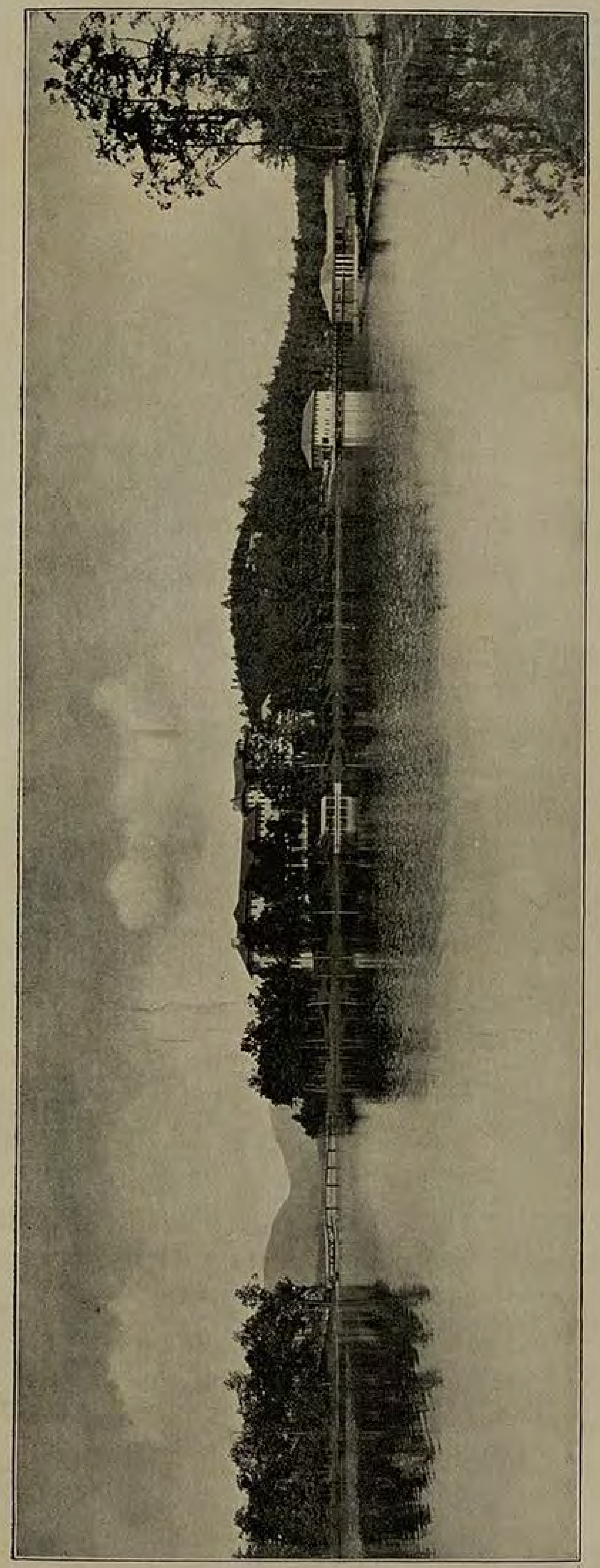



3
8
8
8
8
है
है 
sense and the eye for dollars so often found in his countrymen, he told the life story of a tree and appraised its value as lumber in a breath. He knew every bird and insect that flew before the horses, he was primed with every old Indian legend of the countryside, and kept up a running fire of comment, question and description that made the miles go like yards. Nor were matters historical outside his interest, for he told me of the Mason and Dixon line, which divided the singing of "Dixie For Ever" from the shouting of "The Star-spangled Banner," and he reminded me that the State of North Carolina, in which we were driving that lovely April morning, was the first to be held by Raleigh in the name of his Queen, and was likewise the first to throw off the English yoke, both achievements, curiously enough, dated the 4 th of July.

- But with Nature smiling and singing in the heyday of her spring, these mouldy memories of dead centuries of rapine and rebellion were shorn of much of their attraction. Every turn of the road brought new beauties of land and water. We got down from the cart to view the well-built dam that spans the Horse Pasture River, and again to sit for a moment on a tiny bridge with tons of water roaring beneath our feet to the leafy chasm below. The red bloom of the maple blushed against the white pallor of dogwood, and the horses trotted merrily through miles of untouched jungle, wherein serried ranks of gum, chestnut, birch, sorrel, hickory, pine and other trees stand knee-deep in a tangle of rhododendron undergrowth, while laurel, azalea and magnolia were just then putting on their choicest apparel for the summer bridal of the birds. 
The April sun, which, a few days earlier, had blazed fiercely on the cities of the plain, was only agreeably warm in the dry air of high levels, and broke gratefully through almost impenetrable screens of wood and leaf and flower, flashing back from the lumps of mica that strew every track.

Not, though his appreciation of the beautiful in Nature lagged not a step behind my own, did my Argus-eyed cicerone miss a dollar of the immense value of the lumber that makes such heavy contribution to the picturesqueness of the scene. The timber that he could see without even turning his head totalled to millions of dollars. The highgrade white pine, which towered above the road, would, even at the modest average of ten dollars the square, have kept a German princeling in the lap of luxury for the rest of his royal career. There was a nabob's fortune in inch-thick poplar at fifty dollars the thousand. The bark that clothed the jack-pines, scored though it was by untiring woodpeckers, could all have been taken up by mills in Pennsylvania that would convert it first to pulp and then into postage stamps. Until quite recently, the chestnut was reckoned ornamental only, which means a low standard in American values. The wood is the poorest of fuel and availed only for fence-rails, owning, no doubt, to the ease with which it splits lengthwise. All of a sudden, tanners ran short of material and discovered that chestnut bark would serve their purpose, so that this once neglected lumber now commands three dollars a cord. At such a price, fifty thousand sovereigns' worth might easily be stripped off the landscape without any eye being the wiser. Yet the value 


\section{FLORIDA AND THE WEST INDIES 63}

of landscape has wonderfully gone up in a breathless age when those who perforce live in cities are willing to pay a good price for the privilege of a holiday in scenes of untamed Nature, and standing trees may be a greater asset to an estate than fallen lumber. Of this the man who drove with me that day was fully aware, and I was amply convinced that any future drafts made on the forest that clothes the slopes of Toxaway would be presented with due regard for its æsthetic solvency.

Of the wild life of these hills so short a stay as mine revealed almost as little as I had any right to expect, yet the drive was not without its surprises. At one turn, just after lunch, we put up a cock ruffed grouse, the favourite game bird of the district, where it is known as the "pheasant." A little later in the day I saw the bright crimson body of the "Toxaway," as the Cherokee Indian called the Cardinal, or Virginia Nightingale, the bird that has given its name to this enchanting country; but the most conspicuous feathered family was that of the woodpeckers, as indeed might be expected in such a paradise of timber. Few trunks beside the track were free from the evidence of their bills. On one tree I noticed three downy woodpeckers at work; on another was the little "Flicker," the only American woodpecker, I believe, without some red in its plumage. On the lakes plunged loons and grebes; mocking-birds warbled in every thicket ; and from the swampy margin of the waters came the deep song of bull-frogs. Across Lake Sapphire, under the bow of a boat in which we presently examined some haunts of local trout, paddled a long, black snake, panic-stricken, and making for the 
farther bank. Local tradition has it that this black reptile is a deadly foe of the "rattler," which must either avoid the encounter or be slain. What is known with greater certainty is that the domestic hog eats both with equal relish.

At such altitudes there are no mosquitoes in April, though, in the height of summer, midges probably haunt the fringe of the lakes. The only insects I took note of that day were some lovely butterflies in dark, velvety coats, which floated beside us down the sunlit track. Of four-footed creatures I saw only a few grey squirrels flitting from branch to bough, like birds in fur coats, taking occasional pause on some lichen-covered bole to chatter impudently at the invaders of their wild domain. Those forest fastnesses harbour many deer and a few bears, but not for so impatient a visitor would these show themselves.

Fishing and shooting are the chief resources of a holiday in the "Land of the Sky," but there must be fifty miles and more of riding trails, and for those who are fond of driving there are the nineand-a-half miles of turnpike from Toxaway to Sapphire, and the extension of two-and-a-half to Fairfield, each stage with a lovely lake for its goal. The road, as I remember it, was less smooth than Broadway, but the driver and his beasts would have known every foot of it on a moonless night, and unpruned timber is a grander background than flat-iron buildings, and the wild home of the vanished Cherokee is better than the luxurious surroundings of the modern millionaire. Gone is the Cherokee, but his romance still haunts the overhills and underhills of Ottaray. He knew the peaks and 


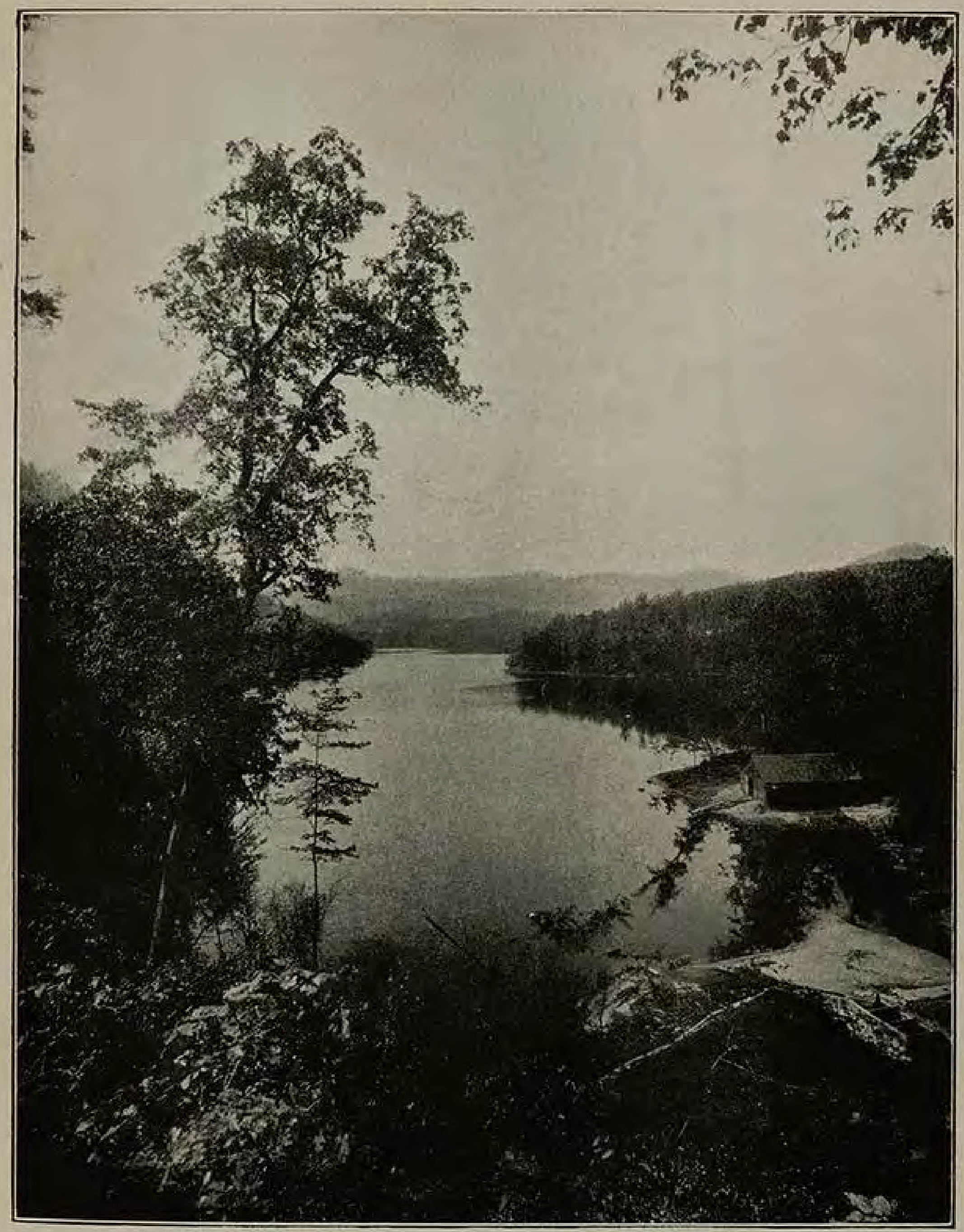

To face page 64 .

THE BEAUTY OF LAKE FAIRFIELD. 
streams of this fairyland, since slandered by dreadful American names that conjure up no thought of romance, by such soft words as Isundayga, Tuckaseegee, Judykulla. For the birds he had such music as Zetilla (the crane), Walseet (the oriole), or Klonteska (the grouse); the fawn was to him Wahneota; even a rat might smell sweeter as Torwillah! Those who boast the beauty of English cannot have known one word of Cherokee. For many of the peaks that rise round Toxaway the Indians had equally pleasing names. A hundred or more of these summits can in the clearest weather be descried from the lodge, towering above the lowlands of Carolina and Tennessee. The lodge itself is 4780 feet above the Atlantic, and around it are grouped Nagestonah (alias Chingman's Dome, 6600), Aconalucta (alias Le Conte, 6612), Salula (alias Slooly, 4490), Isundayga (alias Whitesides, 493I), Tahlona (alias Yellow Mount, 51 32), Klausoona (alias Big Terrapin, 4509), Sunneeharv (alias Enos Plott, 6200), and many others, dying away to the far horizon. A curious tramp of literary leanings, known in the neighbourhood as "Chucky Joe," loves nothing better than to perch atop the lodge and mark down his intimates as the shifting light favours them in turn.

It is chiefly to the fisherman that the "Land of the Sky" appeals for consideration on a lazy holiday. Three thousand acres of still water and a hundred miles of babbling brook and roaring river are, even in that land of big things, no mean attraction for those who throw the fly or swim the worm. Those who would have respite from the artificial round of city life may here enjoy some of 
the wildness of the Rockies and a little of the dreaminess of Florida, together with hotel comforts that would hardly disgrace Fifth Avenue. Imperceptibly the grandeur of Nature is tamed for the entertainment of man. Though few who fish them would suspect as much, even the lakes are artificial, for the brawling Soquilla had none in its own right, and had to be thrice dammed-no mean undertaking even for American brains and capital-ere a scene, already lovely, could be still further beautified by three such sheets of water. Toxaway alone has fifteen miles of shore and a greatest depth of fifty feet, and its waters hold both brook and rainbow trout. The former predominate in Sapphire, the latter in Fairfield. In early springtime, there is a good deal of unconcealed worm-fishing, for it is not here, as elsewhere, the custom to catch trout on the worm and credit them to the fly. On Dartmoor, for example, not long ago, I heard a story of a fine catch of trout, all made on a fly tied by the fisherman, and there was a fine eel in the basket! Visitors at Toxaway, on the other hand, use the early worm and say so. For the matter of that, no resident would believe them if they said anything else.

Such spring heresy need not, however, keep away the artist, for, later in the year, the fly does well-red ibis, black gnat, coachman, grey drake, professor, silver doctor and an irresistible Canadian known as the "Parmachene Belle" all doing execution in their day. On the whole, May and June are perhaps the best months for fishing, for the summer rainfall is heavy in some seasons and hampers what should otherwise be the best sport of the year. Those who scorn the mild exercise of 
casting from a boat on one or other of the lakes have for their playground the banks of the Tuckaseegee, with little overhanging timber to impede their casting, and along these they can walk or wade for miles. In its bubbling waters the trout are wilder and more dashing than in the still deeps of the lakes, and, like most of the running waters, it is, also less fished. Toxaway is the most, and Fairfield the least, fished of the lakes, each of which has its flotilla of small boats. The Toxaway Inn is the finest, as well as most easily accessible from the railroad, but those who put sport before comfort will give the preference to the remoter waters.

The fishery laws in force in Carolina are not sufficiently rigorous to guarantee lasting protection for waters that may, in the near future, be very popular, so the management has therefore codified special regulations for observance by visitors, protecting the native brook trout from October $15^{\text {th }}$ to January ist. The exotic rainbow protects itself by declining all flies and other baits while it is spawning. Again, whereas the State law limits only brook trout to six inches, and makes no limit for the rainbow, the Toxaway code forbids anyone to retain either of less than seven inches. Lastly, the day's bag is wisely limited to five trout from the lakes and twenty from running water, a catch that should satisfy the most skilful and all but the most greedy.

Besides these trout, black bass and ouananiche, or land-locked salmon, will, ere long, be available in those waters. Black bass, than which few sporting fish are held in higher esteem in America, are, in the experience of fish-culturists, even more delicate 


\section{SUNSHINE AND SPORT}

in their early stages than trout. The price of "fingerlings" is ten cents ( $5 \mathrm{~d}$.) apiece, so that their introduction on a large scale is an expensive undertaking.

The only sporting birds of any account, in addition to the ruffed grouse and wild turkey, are migratory duck on the lakes, flocks of which pitch there on the spring and autumn passage between their winter quarters on the Gulf of Mexico and breeding haunts on the shores of Canadian lakes. One evening on Fairfield we put up a flock of bluebilled duck, that may have numbered a couple of hundred, but they wheeled high overhead and dropped again at the farther end of the water without giving a shot.

"Land of the Sky," it is well named. Even at the foot of its mountains we seemed to be at the top of things. The air is rare and exhilarating. The waters show those signs of hurry that belong to water in high places. The vegetation displays a vigour unknown at lower levels. "Sapphire country," it is at every glance. Sunrise and sunset may send shafts of gold and crimson across its blue, but at other times the tint of sky and water alone mingles with the hundred greens of its wild, luxuriant vegetation. 


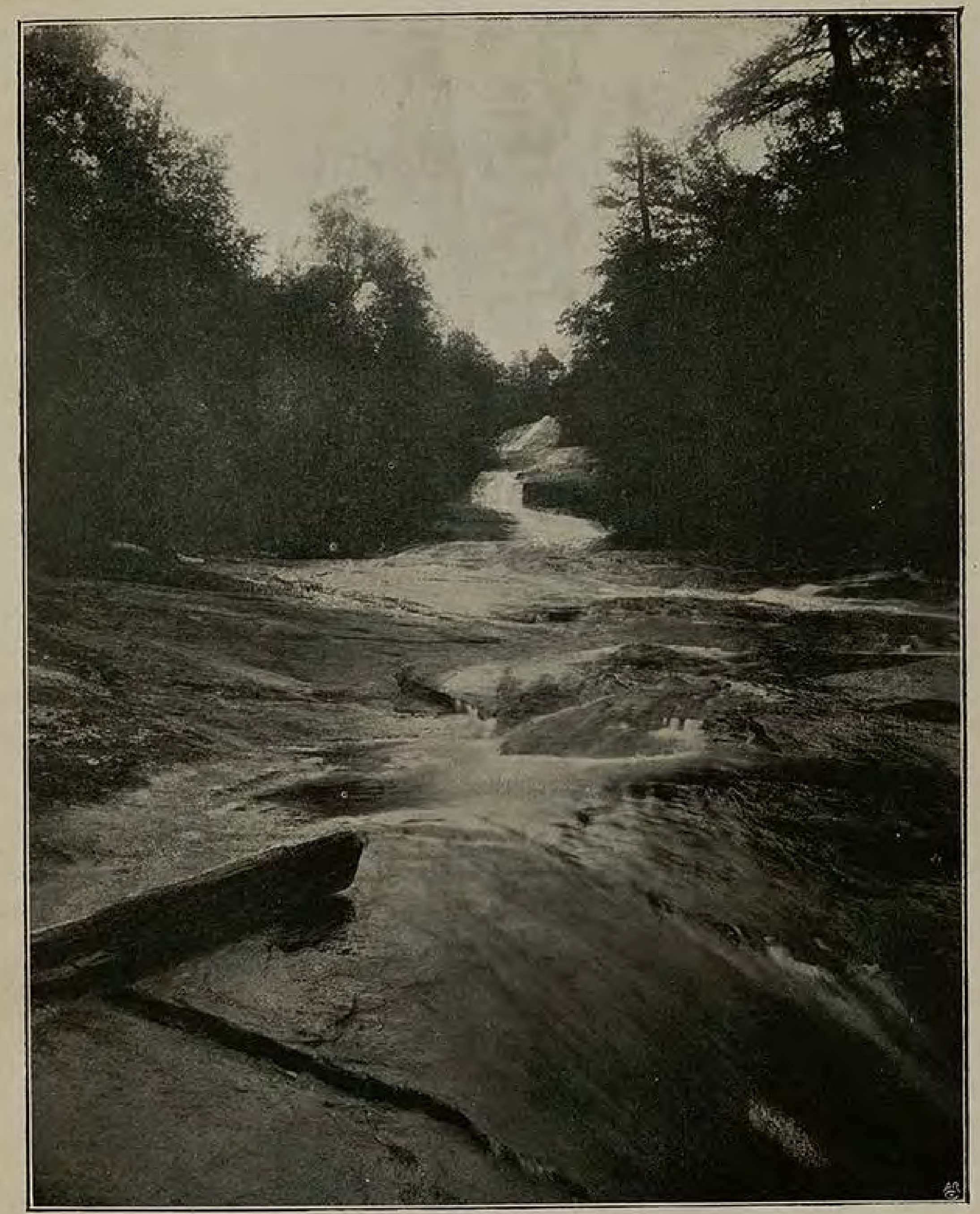

THE MUSIC OF TOXAWAY FALLS.

To face page 68. 


\section{V \\ JOURNEY'S ENDING}

THE only wasted day of all my tour, twelve weeks out and home, and, including minor desertions of the main track, nearer twelve thousand miles than ten, was spent at Hendersonville, a sun-baked hamlet at which, to regain the high road to the south, it was necessary to halt for several hours.

I wish that village all prosperity. May it soon be a city! May it call millionaires its sons! But also may it nevermore see me in its alleys! I have tramped amid the sin, sweat and sorrow of Cornish exiles in the iron-roofed townships of tropical Queensland, and have talked of blue bays in the West country, where red-winged pilchard boats glide out of tiny harbours in the last rays of the sinking sun, until these Australian Cornishmen, homesick at the recollection, have threatened to brain me unless I held my peace. Yet, unless the lapse of years has strangely softened the outlines of the picture, I would rather die on the plains near Mount Morgan than live at Hendersonville. It may be that to its natives this unpretentious village stands for all that is sweet and homely. Long may they rejoice in its mysterious beauty. For me, the place, unlovely had it even been the abode of angels, was yet further discounted by the boorish behaviour of the host of the Blue Ridge Inn, a house admirably suited, no doubt, to the unsophisti- 
cated palate of the itinerant "drummer," but holding out no attraction whatever to anyone travelling for pleasure and not for pelf. I had lunched there, lunched without enthusiasm and driven only by the pangs of hunger to lunch at all, and, while waiting for the departure of the afternoon train for the South, I asked for a cup of tea. The boor behind the counter curtly refused to supply this, assuring me that his hotel was not an eating-house. I remarked that I had gathered as much from the lunch, and we all but came to words. I strongly advise others in the same plight to take the Toxaway train on to Asheville and put in the day in a beautiful town where there are civilised innkeepers to supply their needs.

All that night, and most of the next morning, we were running through the cotton-fields of South Carolina and Georgia until, at length, mosquitobreeding swamps and a more tropical ensemble of vegetation told me in unmistakeable terms that we had crossed the frontier of the last State in my itinerary. Just before noon we ran into the busy dépôt of Jacksonville, the starting point of every line that taps the great winter resort of the south.

Like so many American cities, Jacksonville is the phonix of a devastating fire. It is the fate of some of the greatest cities in a land where man and Nature alike are reckless to acquire grandeur and beauty through resurrection from fire or earthquake. The ordeal is a severe one, but both San Francisco and Valparaiso will, no doubt, be greater than their old selves in a few years' time, and Jacksonville is twice the city it was before the westerly wind swept its ashes into the ocean. 


\section{FLORIDA AND THE WEST INDIES $7 I$}

To myself the place came as an agreeable surprise, for instead of the hot, dusty and unsightly counterpart of Clapham Junction in the wilderness, which a waggish friend at home had led me to expect, I found a delightful city with comfortable hotels, shady and picturesque streets and alluring stores, with the dreamy life of the South relieved by touches of Northern energy. Perchance the luxury of the Windsor Hotel was enhanced by contrast with the inhospitable famine of the Blue Ridge, but it certainly proved a welcome asylum for the long day before the departure of the Southern "express," and a bath, lunch and dinnerthe meals well cooked and served by deft, quiet, coloured waiters-did much to restore my selfrespect and to efface the unwelcome memory of recent discomfort at Hendersonville.

Even for a lover of the wild, the first ramble in the streets of a new city is never wanting in interest, and there was that about Jacksonville which, I confess, attracted me more than greater centres of the North.

On the street cars, with their special benches for coloured folk, I gained my first impression of the Southern attitude towards the emancipated negro within its gates. After the colourless liberty of New York and Washington, these distinctions came with something of a shock, yet there are not a few, if they dared say so, who would gladly see them adopted in the islands of the Caribbean. In Jamaica, I have ridden on an afternoon car from Kingston out to Constant Springs, hemmed in by dusky belles bound for hovels in the hills, and their perfume was not that of myrrh. Those great- 
hearted Northerners who resent such outrage on their black brothers might try whether a week in Barbados would damp their zeal.

The one "lion" of Jacksonville is its ostrich farm, and thither I took a car. Ostriches were the clou of the show, but the chief amusement of the afternoon was furnished by a huge baboon, which, having broken loose, had to be recaptured by three coloured attendants. By one of these it was eventually secured in a huge landing-net, evidently kept for the purpose. There was also an exhibition of driving an ostrich in harness, and riding it bareback. As a side show, coupled with some ludicrous unrehearsed effects, in which the ostrich did most of the driving, the performance was not without merit, but none who witnessed the display would be likely to acquire a high opinion of the ostrich as an addition to the stable. It is even a little less tractable than the zebra; and, as the noble plumes of its tail are prized alike by duchesses and dairymaids, the greatest of living fowl has its legitimate use, and need not be pressed into the senvice of man, who, in an age of mechanical traction, already has more varieties of draught animals than he can do with.

Of course, Osky's too-alluring store of alligator hide in a hundred useful and ornamental devices detained me for half an hour, and released me poorer than I had entered, yet many of the articles were moderately priced, and something in alligator skin is the only characteristic offering to take back from Florida to friends at home. Perhaps the most useful and least costly of my purchases that day at Jacksonville was a broad-brimmed straw 


\section{FLORIDA AND THE WEST INDIES 73}

sombrero at a "quarter" (Is. $\frac{1}{2} \mathrm{~d}$.), which came between me and sunstroke more than once during the next fortnight. Such a hat is light and portable, and can be worn flat on the head or tied round the ears after a fashion that used in my schooldays to be known as "Dolly Varden."

The most abiding memory of my short stay in this city was the conversation of a silver-haired old gentleman, next to whom I found myself seated in a lounge chair in the verandah of the Windsor after lunch, a cavalier of the old type, one who had fought in the War of Secession, of course, on the losing side. He had, in fact, been at Shiloh that fatal afternoon when Johnston died in the rush on the "Hornet's Nest." This interesting veteran had apparently lost all rancour, bowing his head to the inevitable, as well he might do after five-and-forty years had healed his wounds of mind and body. Drinking my coffee and pulling at a damp cigar, I listened with rare enjoyment to his passionless reminiscence, and realised the Crusading zeal with which the Confederates must have fought for their homes against Lincoln's invaders, who, in addition to good Americans, included in their ranks the riffraff of Europe. That many of them, as he told me, swallowed their pride and went to Washington in order that their beloved South should not go unrepresented in the councils of the nation was to their credit, for to rub shoulders with carpet-baggers was, to these proud Southerners, galling beyond words. This is not the place, and this, also, not the pen, to discuss the vital principle of that long and bloody war, slavery, and not, as some allege, the political independence 
of the South. Even the memory of the pampered slaves of Morocco, even the memory of that perfect old gentleman in the verandah at Jacksonville will not let me endorse the principle of slavery. It is wrong; all wrong from first to last-in principle, that is. But men with blood in their veins sometimes, for a brief space, throw principle to the winds. Doing so, I should prefer the wrongs of slavery to the horrors of negroes outraging white women, and being lynched by the crowd. Of the greater picturesqueness of the Confederate cause and of the more romantic personality of its leaders in the field there can hardly be any question, yet in the long run, perhaps, victory went to the right side in the quarrel. What is unforgivable in the north is the brutality with which, after the death of Lincoln, it heaped indignities on the men who were down, even setting the black in authority over the white. This vindictive act of putting the negro in power was a crime that will take the passing of another generation to wipe out. My interesting hotel acquaintance did not whine over the decree of fate. The eternal hankering after the Consule Planco order of things is a morbid symptom of creeping age and mental decay, and of these, though his hair was silver and his shoulders stooped, this urbane and handsome relic of stirring times showed no sign.

From Jacksonville to Punta Gorda, by way of Lakeland, was the last stage of my railroad journey from the Hudson to the Gulf of Mexico, and at the end of it there remained only a short crossing by water to the island headquarters of the campaign of which I had dreamed for half a year. 


\section{FLORIDA AND THE WEST INDIES 75}

Seen from the railroad, Florida looks a dreamy backwater of swamp and tree fern. Its ideal of movement, where movement is required at all, is the pace set by the tortoise and the alligator, and the locomotive takes these reptiles for its models and crawls deprecatingly to the journey's end. The first moiety was achieved in darkness, and the slowness of our advance went unnoticed. At Lakeland there was a long halt, with some shunting of cars, and I was thrown from side to side of my sleeping berth more than once, while (though I knew it not at the time) the guard was solicitously putting out the belongings that should have gone on with me to Punta Gorda.

Next morning, little dreaming that every turn of the wheels was bearing me farther from my luggage, I looked sleepily forth on a monotonous landscape of hot, moist desolation relieved by an occasional grove of pineapple or orange, with a few draggled human beings at work on the crops. I congratulated myself on the approaching end of a long and tiresome journey. Pelicans, which I had not seen in the wild state since I was in the Suez Canal ten years earlier, floated lazily over muddy creeks ; clouds of mosquitoes hovered about every ditch; all Nature seemed only half awake, and of human dwellings there were few signs, though the driver of the locomotive evidently regarded it as a moral obligation to pull the train up at every pig-pen or hen-house on the off-chance of some passenger emerging from the long grass. Is it possible that this land of sun and sleep can be the theatre of the revolting drama of white slavery, in the course of which black overseers flog hapless 
emigrants to death, as related in New York newspapers? or are the reporters masters of the art of writing minor fiction? I hope so indeed.

- No foolish slavery to the time schedule inspired the engine-driver during that southern crawl through Florida. Before we left Lakeland, we were one hour late; by ten in the morning, we were two hours late; before the end came, we were so late that all reckoning had been abandoned. When asked if that train always took its obligations so easily, the dusky conductor on the car smiled broadly. Breadth of smile is, in most niggers, the saving virtue of an otherwise unpretentious physiognomy. The one diversion during that funereal progress was when a large picnic party of women and children boarded the train at one siding and left it an hour later at another.

Already in the train the talk was of tarpon. A long-legged individual, who, by sprawling over most of the car, kicked my camera off the opposite seat and then apologised with the air of having conferred a favour (more democracy, I suppose), guessed my mission in those parts, though I had no fishingtackle with me in the car (and none, had I known it, within fifty miles), and began to tell anecdotes of the season's fishing. At first, his chatter was continuous and amusing; afterwards, it was merely continuous. When at last I realised that his advice was not wholly disinterested when he counselled my giving up Useppa and proceeding by the train to Fort Myers, he bored me so deeply that I first feigned to doze and then acted the part so well that I fell fast asleep, and the nigger awoke me only when we were running into Punta Gorda. 
It was blazing hot down here in the South, this last Saturday of April, and, having gathered from my communicative fellow-traveller that the only regular boat for the island must have left early that morning and that there would be no other until the Monday, I resolved to be extravagant and charter an oil-launch to take me over, which might, he thought, cost as much as twelve dollars. Yet better, I thought, fifty shillings out of pocket and my journey ended that night than fifty hours of Punta Gorda, hardly a gay resort at the best of times, and now sunk in the inanity of its summer slumber, with all the tourists fled North and only desultory natives loafing in the doorways of its one street. Such was the picture that had been drawn for me of Punta Gorda out of season, and it more than justified its reputation.

To be stranded in such a backwater over the Sunday and perhaps miss a day's tarpon-fishing into the bargain seemed dear at the economy effected and a very half-hearted way of starting my campaign against the herring, and I at once made inquiries of the gigantic negro who led the way to the baggage van about a launch. There it was that I made the agreeable discovery anticipated in the course of this narrative. I raved at the nigger, who grinned, and I raved at the baggage-clerk, who, though no more to blame in the matter than myself, took my upbraiding with the meekness of a Trappist. Three weeks later, indeed, he heaped coals of fire on my head by holding up the train for several minutes until I and my trunks were safely stored on board, en route for Port Tampa.

And now followed a wretched day of smothered 
wrath and wasted expletives, since I had not an acquaintance in the place and was forced to rage alone. To add to the irony of the situation, the palatial hotel beside the dépôt, to which I at once repaired, had technically been closed for a week or two. The proprietor explained civilly enough that he could give me a room for the night, but that I should have to get my meals in the town. This was what Americans call the "European plan" with a vengeance, and it had its drawbacks in a hamlet where eating-houses are very few and very bad. To the first of these, an unsavoury-looking barrack in the only street, I betook myself with a demand for lunch, and Boniface, a greasy saloonkeeper in his shirt-sleeves, said that I could have some dinner if I took my hat off. Staggered by this unexpected behest, I looked around for some explanation and espied, at the farthest table in the dining-room, what might at first sight have passed for an ant-eater in a bath robe, but what eventually proved on closer scrutiny to be a generous-looking female in summer attire. In deference to this appalling snack of womanhood I removed first my hat and then myself, leaving Boniface gasping at my waywardness. Who, after this, shall say that American chivalry is dead?

My next raid on the slender, local commissariat was a little happier in its results, for at an equally unpretentious tavern beside the railroad I managed to get some fresh fish, decently cooked, and a cup of indescribable tea, without also receiving a lesson in manners.

The meal occupied only a few minutes, and time had to be killed somehow. It struck me that, as 


\section{FLORIDA AND THE WEST INDIES}

the railroad siding overlooked the river, there should be some sort of fishing to while away an hour or two. The railway nigger met me at the door of the eating-house. From the look of surprise on his face, I gathered that he had been deliberately stalking me as fair game, and I was quite prepared to be exploited if he could dispel my boredom. In reply to my angling queries, he told me that large tarpon could be taken higher up the river and that Punta Gorda had formerly been a favourite centre for tarpon-fishing with the gorge bait, a method that I do not favour. He had, however, a boat, and could get bait for smaller fish, and we eventually struck a dollar bargain for him to take me out at four. Every fisherman looks forward and back with peculiar interest to his first essay in strange waters, and, in happier circumstances, my first day's fishing in America would have been an occasion. As it was, I still smarted at the loss of my luggage and also under the lesson in deportment from the oily knave in the saloon. Yet when we pushed off from the steps, I found myself keen enough. In the boat lay a bamboo pole with tight line and a single hook, and for bait he had brought a bucket full of a spratlike fish called in those parts minnows or "shiners." These were used dead, hooked by the tail, and a bottle cork, about four feet from the hook, served as a float. We drifted past some large building, an ice factory, if memory serves me well, and then he rested on the oars and asked me to swing out the line. I did so; down went the float, and I struck, only to recover the bare hook. This happened four or five times in rapid succession, 
and my interest was quickened by his assurance that the robbers were trout. At last, striking, perhaps, a little more sharply, I hooked my customer, and a very pretty struggle followed, the fish boring all round the boat, like a mackerel, and bending the bamboo until it looked as if it must snap. The end came at last, and I had the satisfaction of seeing a handsome spotted fish of about two pounds. Trout? Well, there were the spots, and the fight had been not unworthy of that fish. But there was no adipose fin, and a closer examination revealed that this was not a member of the salmon family. Years earlier, in Australia, I had grown accustomed to hearing fish miscalled trout and salmon, with much less resemblance to those forms than this one, and a little later I learnt that this was correctly known as the Spotted Squeateague, known in Florida indiscriminately as "trout" or "sea trout," and considered excellent eating, save when, as at that season, the flesh was infested with parasite worms. I caught five or six more of the same kind and size, and then, seeing that a heavy thunderstorm was unmasking its batteries behind the hotel, I got back to the shore. The hotel is an immense barrack, and in the winter months it is, I believe, a "home from home" for hundreds. In summertime, it is about as gay as the Morgue, and to be the only guest under its capacious roof is to get a severe attack of the blues. The thunder rolled ominously overhead, and daylight faded quickly before the gathering darkness of the storm. Fortunately, I found in a corner of the gloomy hall a piano of good tone, and that instrument stood between me and a sudden desire 


\section{FLORIDA AND THE WEST INDIES 81}

for self-destruction. My indifferent strumming of popular ballads at anyrate added a little to the gaiety of the situation by drawing forth the manager's wife and sister-in-law from their hidingplaces. I have no wish to pose as an Orpheus. Indeed, so crude is my poor little knack of playing "by ear" that I hesitate to present myself in the character of a troubadour earning bread by his lute, but the fact remains that a very welcome cold supper, for which I had in vain thrown out hints earlier in the afternoon, made its appearance that evening in my room, a banquet for which $\mathrm{Mr}$ Concannon stoutly declined to make any charge in my bill.

As foretold by the patient baggage-clerk, all my luggage came on by the night mail from Lakeland. Having made arrangements for an early call and for a launch (at eight dollars) to leave the pier at six, I turned in, full of supper, tobacco and goodwill to all mankind, even the frowsy caterer round the corner and his lady friend in the bath-robe. Fitfully I slept through a conspiracy of thunder and mosquitoes to keep me awake.

Next morning, at the hour named, I and my kit were stowed aboard a little launch that made good going down the harbour, convoyed by heavy pelicans and graceful man-o'-war hawks. From behind the screen of mangroves that fringe every islet peeped frightened egrets, inspired with a distrust bred of encounters with the plume-hunter. Fat mullet leaped in the gleaming shallows, too quick in their movements for the clumsy fishing of the greedy pelicans.

At length, at breakfast-time on the Sunday 
morning, I stepped ashore at Useppa Pier. The first object to meet my gaze was a huge tarpon of over I 20 lbs., a prize, as I soon learnt, of the evening before. Forgotten were all my troubles as I gazed at the monster herring, the first that I had seen in its native air, untouched by the taxidermist.

This looked like business at last.

I had arrived! 


\title{
PART II
}

\section{TARPON-FISHING AND OTHER SPORT}

\author{
I \\ THE GLAMOUR OF TARPON-FISHING
}

Blaze of sun, shimmer of moon, pall of blackest night jewelled only with the cold fires of Southern stars, the fighting spirit of the great tarpon can generally be roused, and the king of all the herrings is game to the death against all comers at any hour of the twenty-four.

If, as compared with some other struggles in the angler's record of carnage, the issue is short, not the fish is to blame, for he prolongs the battle to finite possibilities, but the fault lies with the ruthless mechanism brought to bear on his defeat. American sporting methods, though differing in some view-points from those of England, are on the whole quite sound, and it is no disparagement of them to say that, short of electrocution, all the resources of an eminently mechanical and inventive nation have been employed against the big-finned game of either seaboard-against the tarpon on the east side, and against the yellowtail and tuna on the west. The rod is powerful enough to hold a shark fourteen feet long for upwards of two hours, 
an experience, this, out of my own log. The reel is furnished with diabolical brakes and drags, against which few fish but a tarpon could put up the fight it does. The line is tested almost to the breaking strength of a runaway rogue elephant. The hook, very carefully tempered, is soldered to a snell of chain and piano-wire that would hold a Cunarder at her moorings. In the hands of even a novice, such a combination is a formidable one to fight against. Used with such skill as there is room for-not, as I shall endeavour to demonstrate, a very high degree-it is well-nigh irresistible.

Not every tarpon that "strikes" is hooked or landed, for the mouth of this great fish has adamantine corners that no hook can hold. As these monsters browse, head downwards, on the coralbeds at the bottom of the Pass, they are sometimes foul-hooked in the nostrils, but, although the tarpon has the nez retroussé of all the herrings, its nostril is a small target to hit forty feet below you, and, even if struck there, the hook will soon relax its hold unless the line be kept absolutely taut. Once the point and barb are well home in one of the few vulnerable corners of the head, once the splendid fish has made its first maddened jump in vain, failing to fling back the hook in the dejected angler's face, there is just one excuse, one and no more, for not getting it exhausted to the boat or beach according to local custom. The one excuse is when a large shark joins in the game and engages in a triangular duel, of which more will be said later. As for the tackle breaking, there is, with the exercise of ordinary care, very little chance of it. It is true that the lines supplied in 


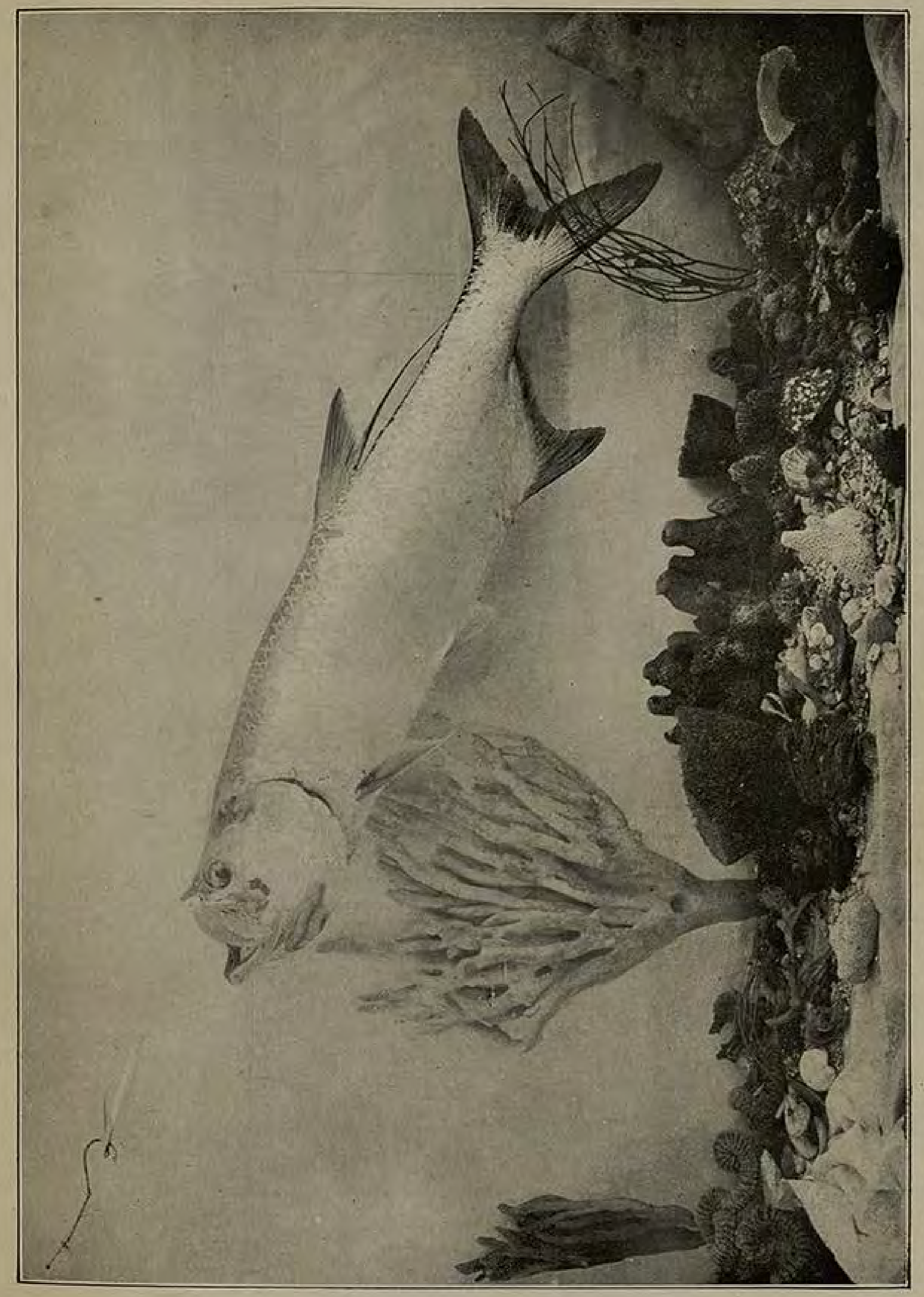



के 


\section{FLORIDA AND THE WEST INDIES 85}

New York vary in quality, but the same might be said of most tackle supplied in most cities. So much American tarpon-tackle is perfect that a rare flaw need not be made of too much account.

Given a sporting chance on tackle less peremptory, the tarpon would, I am convinced, acquit himself to even better purpose, and the average of captures to strikes, which experts complacently regard even now as one in three, would be fewer. Even with such a handicap as that imposed under present conditions, he jumps superbly in the fierce glare of the noonday sun, jumps again and yet again, throwing off golden showers of iridescent spray as he impetuously shakes his bristling head from side to side in mad endeavour to throw out the cruel hook. In the pale radiance of a full moon, im runderschönen Monat Mai, the fish looms a gigantic vision of black and silver, projecting itself in the air beside the boat, its form distorted, magnified, blurred by the deceptive lamp of night. Comes an evening without moon, and the summer phosphorescence of the warm Gulf water gives the weirdest effects of all ; for sudden pale gleams break the blackness below and mark the pathless dash of sharks over the hidden dwellings of the coral creatures, to whom they must seem as meteors flashing through the night, and the tarpon rushes like a signal rocket, setting the water afire and, as it jumps, breaking into wondrous coruscations as the cold fire drips from it in its fall.

Each experience has its niche in memory's album. Those who fish for pleasure only, preferring comfort to the making and breaking of records (an unbridled passion for which is the 
worst symptom of Americanitis), love best the friendly light of day, the sight of trees waving on island banks, the song of land-birds and the flight of sea-fowl, the view of others fishing close at hand, the exchange of chaff bandied among the boats. Most often does one hear the favourite injunction to "Make him jump!" in reference to the unathletic sulking of many monsters of the Pass, the ponderous jewfish, boring grouper and massive sharks. All of these in turn seize the tarpon bait and waste the precious time of such as have not the heart to cut their line and take a new hook for better game. Among sportsmen in the Pass prevails the unsophisticated mood of schoolboys home for the summer holidays, and on them such old jokes never pall.

Others would rather fish on moonlight nights. Discounting the enjoyable social element which prevails in daylight, these cool, still nights can be exceedingly pleasant. They afford just enough light to swear and fish by, yet without the pitiless blaze that all day long, often without the saving grace of a passing cloud or the soothing breath of a gentle breeze, dazzles the eye and blisters the skin, bidding those who know the tropics wear smoked goggles and long sleeves, and dooming those who do not to buy their knowledge at the price of sore eyes and tender arms.

The moonless night is by general agreement dreary and comfortless, interesting only as a rare experience of uncanny impressions. The depressing isolation of hours spent in a small open boat wrapt in the impenetrable pall of night, on the threshold of a Gulf that has a nasty reputation for 


\section{FLORIDA AND THE WEST INDIES 87}

tidal waves at a moment's notice, and that is prolific in monster sharks and leaping rays, cannot conduce to merriment. Still, like the Chamber of Horrors at Madame Tussaud's, one dark night in the Pass should not be missed by any who take an intelligent interest in the gruesome.

Ten or twelve thousand miles, out and home, with no other purpose than to catch a tarpon, may seem a long and costly pilgrimage, and six weeks are, it must be confessed, a big slice out of the year of the professional or business man. I took twice that time, but unnecessarily so far as the main object of my trip was concerned, for I had accomplished this when less than three weeks out from home, and within a fortnight's journey of Liverpool. As for the cost, which, as will presently be shown, need not exceed one hundred and fifty pounds, I cannot, in view of the magnificent sport and unique experience, regard it as prohibitive, particularly when I remember that a friend of mine had to give up a well-known salmon-fishing in the north country when the season's rent passed two hundred pounds, as his professional work did not permit of his spending more than one whole week and five more weekends on the water.

I am not for a moment comparing a month's tarpon-fishing with a day's salmon-fishing. I do not, for the matter of that, feel any desire to compare it with any other style of fishing in river, lake, or sea. Salmon-fishing is an altogether different sport. The salmon must be treated with diplomacy else it breaks the angler's cast. It may therefore take hours to land a large salmon, and an historic instance is on record in which a well-known fisher- 
man played a salmon all night long, only to lose it in the end. A minute's fight for every pound of the salmon's weight is on some waters considered happy despatch, though everything depends on the conditions under which the fish has to be landed. The diplomacy used towards the tarpon is rather what some folks call the "new" diplomacy, that is to say less delicacy and more elbow-work, otherwise less give and more take. I have seen a tarpon exceeding a hundred and fifty pounds on the beach within five-and-twenty minutes of striking, and have myself landed two of one hundred and eight pounds apiece within the hour. This result is due to the tackle employed. I shall have occasion to explain this more fully.

The attractions of tarpon-fishing are many. First and foremost, perhaps, we may place the great length and weight of the fish. Those whose sport has hitherto been with little moorland trout at home can hardly conceive what it means to have a stand-up fight, however brief, with a fish longer and heavier than the fisherman. The best tarpon beats the best man in both weight and measure: seven feet, and between two and three hundred pounds, a veritable Daniel Lambert of the underworld. To most other sea-fish taken with rod and line, the tarpon is as elephants to snipe, and the sea-angler likes his big game as well as the shikari. Perhaps, be it admitted, there is more art in shooting the snipe; there is assuredly more in catching the trout. In successful tarpon-fishing, luck and brute force play, if the truth must be told, the paramount part. The luck consists in getting strikes from tarpon and not getting them from vermin such 


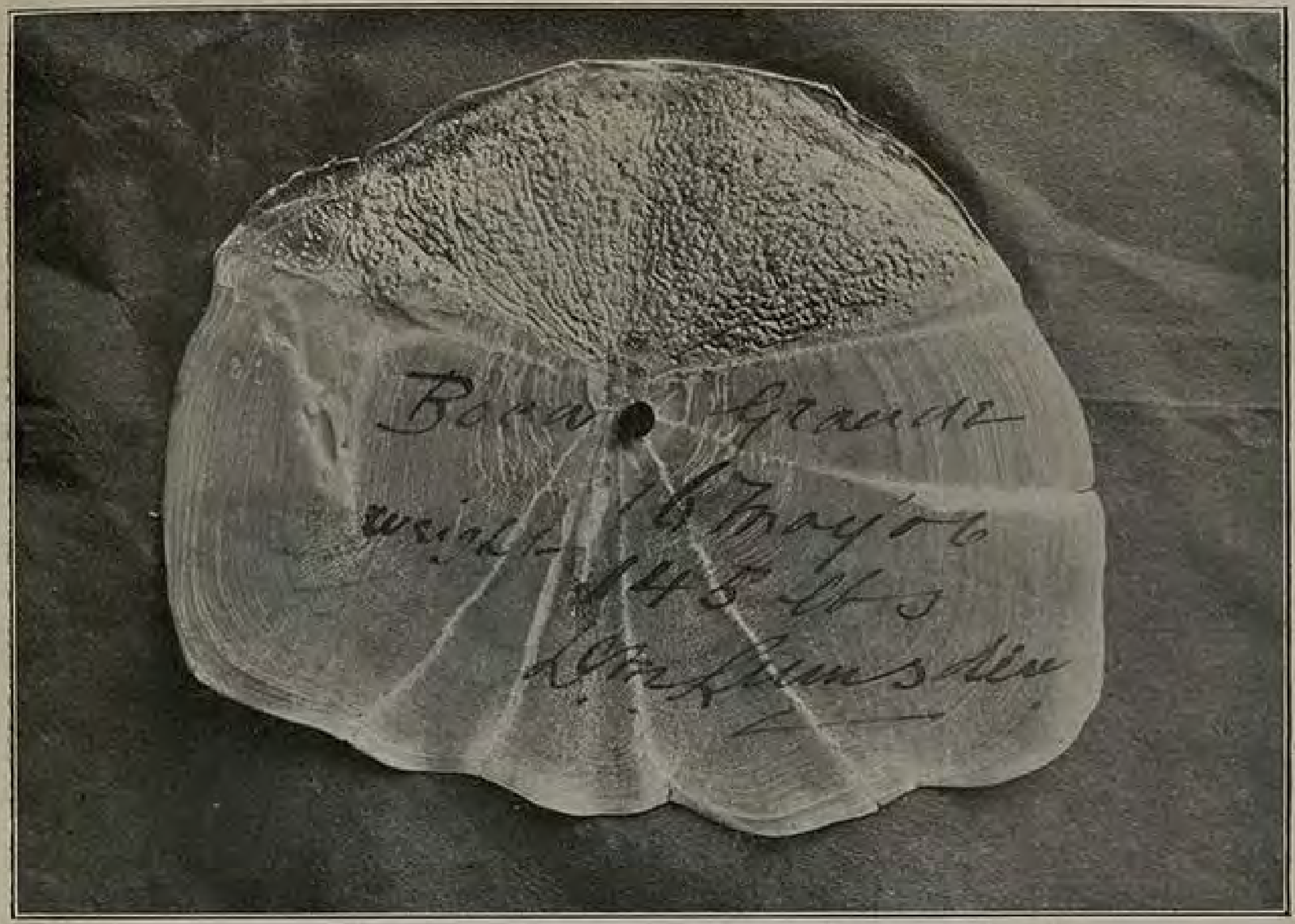

A TARPON SCALE.

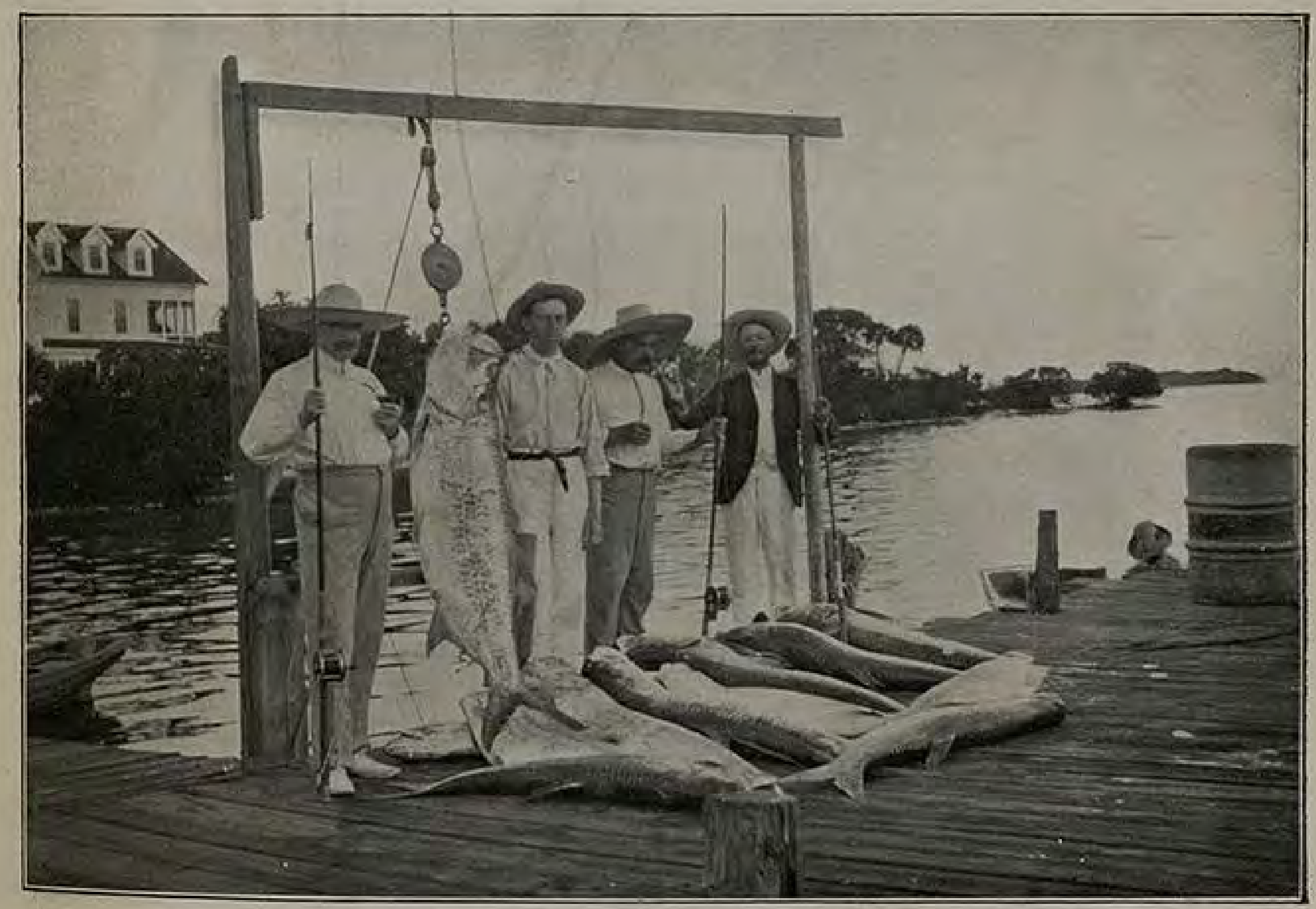

To face page 88.

SLAYERS AND SLAIN. 


\section{FLORIDA AND THE WEST INDIES 89}

as sharks and jewfish. The brute force is expended in tiring out a fish of great strength and resourcefulness, which, in spite of the tackle, might baffle a weak arm. You do not want to be a Sandow, but strategy is not in it with savagery, and he kills most fish who gets each quickest to the beach. Some of my American friends will perhaps condemn what may seem to them a perverted view of tarpon-fishing, but, looking at it from the standpoint of sport at home, I take my risk of blame, knowing that the facts are as stated.

Yet luck and brute force are elements in the wild life so dear to the sportsman, in the battle of the jungle and the silent struggle of the ocean, and should appeal to us. If fishing were a mere equation of skill and previous knowledge, if fish were caught with brains only and not with brawn, if neither the caprice of fortune nor the strength of a good right arm had their share in the making of a good bag, why, to Jericho with the sport of sports! It would be a pastime only for professional chess-players. It may at once be said that tarpon-fishing will give no joy to those who find only half their pleasure in catching fish, and the other (and greater) half in bragging to their friends that their success was the result of long and patient study of the ways of fish. In tarpon-fishing, neither previous experience nor long and patient study are the passport to success. The tenderfoot is on all fours with the veteran, and I would rather have, so to speak, an ounce of luck than a ton of experience.

The brightness and beauty of Boca Grande on a fine May morning, with the mocking-birds singing their love-lays in the thickets, pelicans wheeling 
lazily over the shallows and dashing man-o'-war hawks plunging to cram their craws with stolen garfish and other fruits of the Gulf, also contribute much to the enjoyment of the sport. There is a fascination about the Gulf in calm or in storm. Lashed by the hurricanes that in those latitudes spring up even more suddenly than new forms of Government, it is terrible, and its cruel combers whip and shake the coral beaches and sandy strands, until those who crouch stormbound on the lonely keys are filled with the dread of its hungry grace before meals. That is no weather for tarpon-fishing, but there is grandeur in the sight for those who are snugly berthed in the Pass on yacht or houseboat, listening to the dogs of war, yet fearing nothing from their bite. In the spring, the weather is mostly fine, and then the Gulf is like a lake, a paradise for yachts, an Eldorado of the rod's big game-the leaping tarpon, the gallant kingfish, the flying whipray, the basking turtle-and a myriad wonderful little creatures that untiringly rear their coral towers from the sea mud to the upper air. For the fisherman who does not shirk a fight against odds, with some trifling spice of danger to lend piquancy to his holiday, there is no sea anywhere on earth to rival the Gulf of Mexico.

The scenery of Florida, or of the little I know of that State, is nowhere beautiful. Flatness robs it of pretension to that quality. Its rivers are thick and sluggish for lack of mountains to lend them speed from their source to the ocean. Its vegetation, unquestionably luxuriant, is of that monotonous sub-tropical type which soon wearies eyes accustomed to the sweeter verdure of the North. As 


\section{FLORIDA AND THE WEST INDIES 9I}

soon as you penetrate beyond the salty sway of the ocean into the dreamy hinterland beyond, all Nature exhibits a lifelessness, soothing at the first, but soon oppressive by reason of its stagnation. The low shores of its thousand isles are suffocated in the tortuous embrace of the ghostly mangrove, a vegetable with something reptilian in its habits and appearance. Swamp and backwater, the slimy haunts of snakes and alligators, struggle with sand and salt for mastery in a land of lifeless silence. The quadrupeds are few in variety and shy in showing themselves, and the reptiles remain in hiding through the light of day. Yet, though the inland scenery be jejune, the coast is certain to attract those to whom a holiday is no holiday without sea waves in the drawing.

One great virtue at anyrate Florida has in the holiday diary, and that is the complete lack of the strenuous life so characteristic of the restless cities of the North. This is the land of flowers, where the hammock and siesta and the gospel of mañana, a legacy perhaps from the brave days when de Avilès drove French heretics into the sea for the greater glory of his master at Madrid, are part and parcel of the daily life. Dollars are spent here, not made ; and men drift down the sea of life much as their flat-bottomed craft drift down the overgrown Caloosahatchee. The free-and-easy unpunctuality of the railroads suggests travel in the land of the Pyrenees, and there is still less formality in the water communication that plays so important a part in this watery land. Every day, if the captain is so minded, a mail-boat calls among the islands and fish-houses, starting from Punta Gorda and 
arriving eventually at Fort Myers, or vice versâ. Some of the boats are of obsolete construction, and breakdowns are frequent. This chance of isolation, without even a telegraph wire, from the outer world lends added charm to such a holiday. Men who boast of their delight when beyond reach of the electric wires (as a rule, these are the very men who walk out to meet the postman three times a day) can realise their lazy ideal at Useppa. For such reasons, the gentle, unprogressive Southern State is a delightful theatre for the fisherman's holiday; restful, balmy, far from the crowd that maddens, conducive to contemplation, a backwater of life's flood, yet hiding under the calm surface of summer seas and in the depths of its sleepy creeks such mighty game as can put rod, reel and muscle to the severest test.

Of the social side of tarpon-fishing in the Pass something has already been said. It is not the solitary, aloof amusement that too often breeds in the fisherman a selfish and morbid aversion from the company of his fellows. The morning and evening mess, the brisk conversation on the launch, even the less comfortable tiffin in the shadow of the lighthouse, all contrast pleasantly with the solitary. interludes spent by each in his own little skiff. Given a company of a dozen sportsmen, all ready to give and take chaff, and no less ready with help if needed, each inspired by friendly rivalry that never degenerates into jealousy, it would be strange if the holiday could not pass merrily.

Everything at Useppa Island is cut and dried, for has it not these many years been the recognised headquarters of tarpon-fishing in the Passes known 


\section{FLORIDA AND THE WEST INDIES 93}

as Boca Grande and Captiva? True, the commissariat in 1906 was open to criticism, being indeed a little worse than even enthusiastic sportsmen cared about, even though they hankered not after the cuisine of Sherry's or the Savoy. There was, it is true, no single case of death from starvation, but such rough fare, even with the difficulties of transport, was uncalled-for at the very sufficient charge of $3 \frac{1}{2}$ dollars (1 $5 \mathrm{~s}$.) a day.

The manager, $\mathrm{Mr}$ Sherman, was the soul of politeness, but the resources at his disposal were too meagre to enable him to satisfy even the moderate demands on his catering, and the luncheon that was sometimes put up for us to eat at the lighthouse would have been the subject of complaint in a workhouse.

Otherwise, the arrangements are perfect. There are boats and guides for all; there is an oil-launch in attendance to take us to and from the fishinggrounds; you can be called at any hour between midnight and midday, and breakfast is served when ordered. Everything is made subservient to the fishing. If the truth must be told, Useppa Island is inconveniently far from the Pass, but it is the nearest terra firma accommodation available, the only alternative being to charter a yacht or house-boat, which costs a good deal more.

Such, then, is the glamour of tarpon-fishing. It appeals to all sorts and conditions of both nations. Always just strenuous enough to give healthful exercise, it is never taken so seriously as to constitute a worry. It braces the body, but relaxes the mind. To rich and poor alike it is a joy. Millionaires go to it from Chicago and paupers 
from Devonshire, and all go back home younger and better men. In a land where many are rich it is refreshing to find men of many incomes meeting in a common enthusiasm. The waiting may be keen, the struggle may be hard, yet failure and success take turn and turn about too quickly for either to become monotonous. Some, like Lord Desborough or $\mathrm{Mr}$ and $\mathrm{Mrs}$ Turner, have caught so many tarpon that they may be excused for having tired of the game and sought their sport in other waters. Yèt most who visit Boca Grande once come again, and what was first sought as a new sensation develops in many as a craze. 


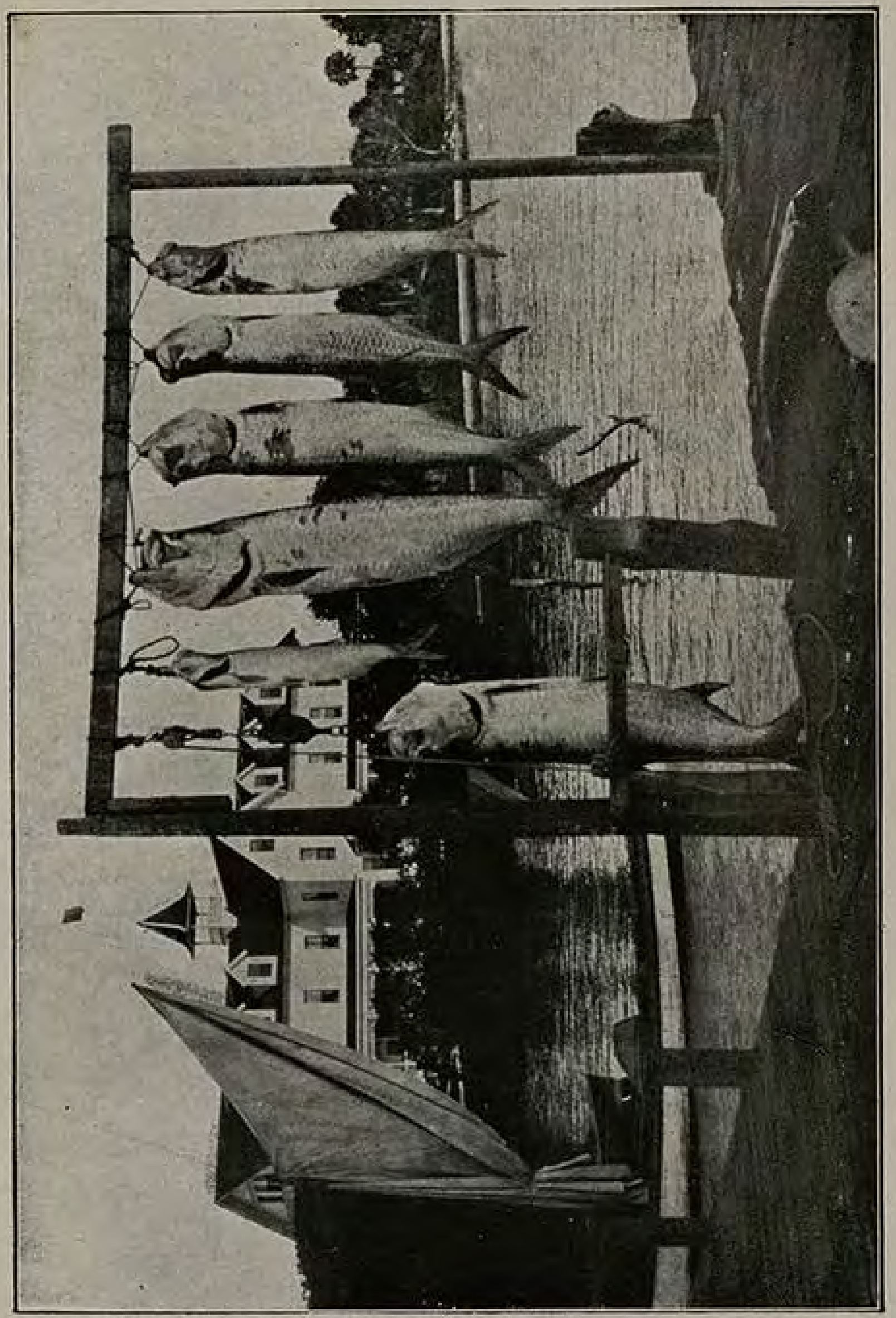

$z$
$z$
$\frac{a}{2}$
$\frac{a}{5}$
$\frac{0}{5}$

gे
s.
है
हैँ
है
है 
As tarpon-fishing is attracting an increasing number of enthusiasts, partly, no doubt, owing to the apparent falling off of tuna at Santa Catalina Island, on the Californian coast, a brief digression on the cost of the trip may perhaps be of use to others minded to try a fall with this grand fish. Why there should be so much mystery about this question of expense I do not know, but I had the greatest difficulty in arriving at an even approximate idea of the money I should require to take with me, so that, as already related, I took none at all. The explanation may lie in the fact that many who go after tarpon are sufficiently endowed not to bother about ways and means and they honestly cannot say just how much the trip cost them.

Briefly, I should suggest a sum of one hundred and fifty pounds and a holiday of six weeks as the minimum expenditure of money and time. This should allow for first-class travel all the way, a fortnight at Useppa and the mounting of one specimen fish as a trophy. On the other hand, it makes no allowance for a stay in New York or any other city by the way.

The expenses of the tarpon-fisherman fall under three heads: the cost of travel, the cost of tackle, and the cost of fishing and hotel accommodation on the spot. 
I. As regards the cost of travel, the journey out and home will amount to about seventy-five pounds on the basis of direct first-class travel from Liverpool to Useppa and back, viâ New York and the Southern and other railroads. Such a sum includes, sufficiently but not lavishly, personal expenses on ships and trains, but the traveller cannot on such an estimate drink champagne, nor will he be able to tip stewards and conductors on a scale to shame millionaires. Anyone minded to break the journey at New York should be able, from what has already been said, to arrive at an idea of the additional expense entailed.

II. The cost of tarpon-tackle is heavy, particularly if it is to be used once only, for a fortnight or three weeks. Very little change will remain out of a twenty-pound note-a severe tax for the paraphernalia of so brief a fishing holiday. My own account with Vom Hofe, of Fulton Street, New York City, the acknowledged premier dépôt for tarpon tackle, reads (translated into sterling) as follows :-

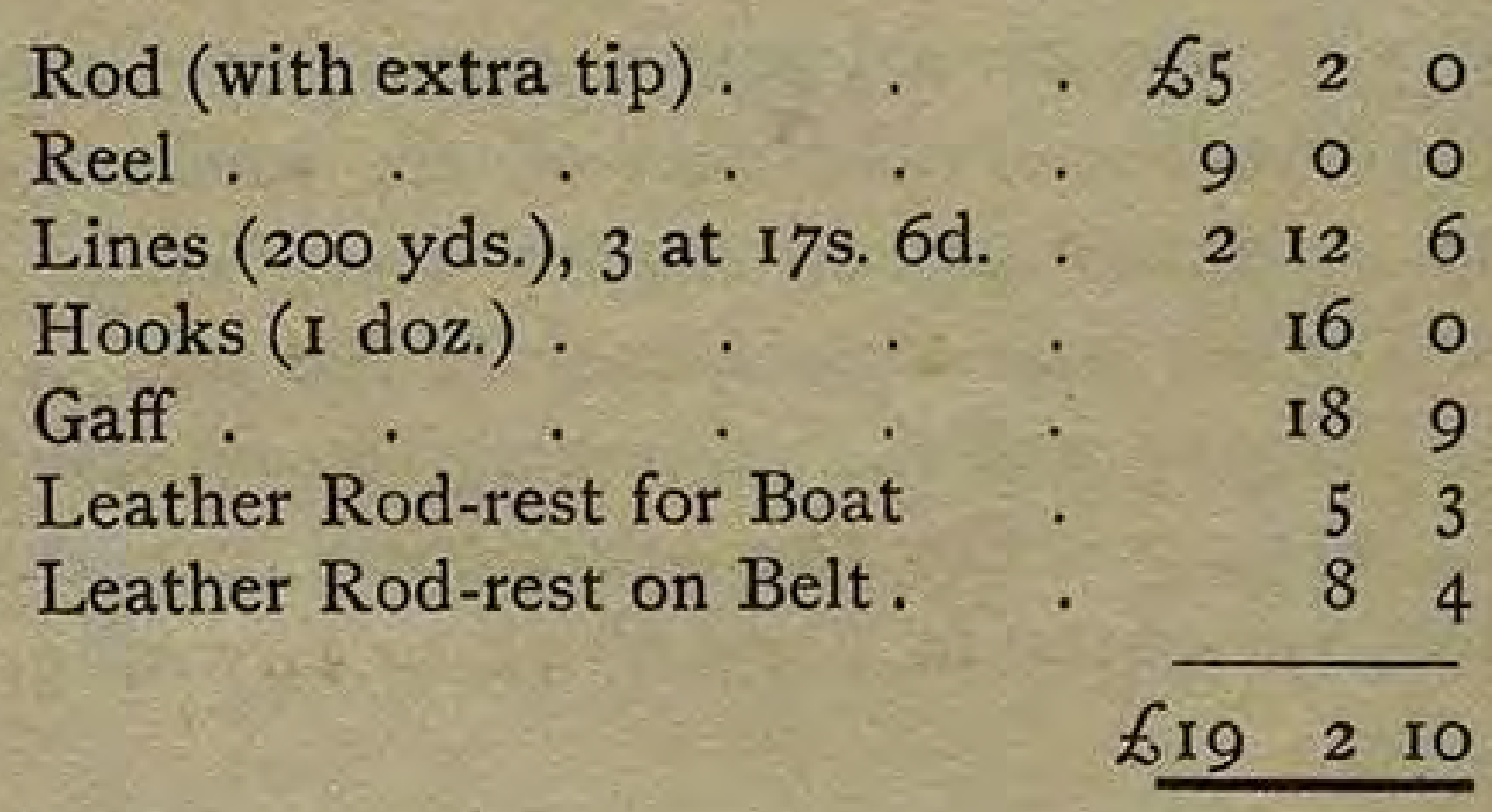

To this may be added another half-sovereign for the purchase of sinkers, a stock of which is kept at Useppa, though in this department, as will pre- 


\section{FLORIDA AND THE WEST INDIES}

sently be explained, a considerable economy can be effected.

This tackle bill, heavy enough for the average ambition, does not satisfy wealthy Americans, many of whom take the outfit in duplicate, determined not to be baulked of their sport by want of tackle. There is sound reason in the spare rod, for both tips are sometimes broken by sharks (my own were) in the course of a week, and in careless hands even large tarpon will put them out of court. The second reel I regard as mere extravagance, for Vom Hofe makes these reels so near perfection that the bare idea of anything going wrong with them in so short a time is not to be seriously entertained.

Those who go to the tarpon grounds by way of New York will certainly buy their outfit of Vom Hofe, for since he himself has fished at Boca Grande almost every season since tarpon were first caught with rod and line, he has first-hand knowledge of all the difficulties and requirements of the sport, and has been able to embody in his tackle virtues that he could never have arrived at without such close personal study of the rules of the game. No man in his senses would go to him for salmon flies for the Tweed (and if he did Vom Hofe would, in all probability, see him to the door), but he is the man to go to for tarpon tackle for use in Florida. His wonderful reel touches the high-water mark of efficiency. So, as the Scotsman said at the end of an expensive railway journey, it ought to, for it costs as much as many a complete outfit for fish in other waters. For those, however, who seek moderate tarpon-fishing in the West Indies, where, though less known, it is sometimes excellent (I 
quite recently had news of the capture of tarpon at Colon), and who cross the Atlantic by the Royal Mail boat and not viâ New York, it should be quite possible to buy the requisite tackle of English makers. Messrs Hardy of Alnwick supplied me on this occasion with a rod, reel and other tackle on which, with very little difficulty, I caught a couple of fish weighing $80 \mathrm{lbs}$. or so ; and Messrs Farlow, Holbrow, and others, also make a speciality of tarpon tackle, as far as can be done without firsthand knowledge of the sport.

Costly as is the outfit, it is fair to remember two facts with regard to it. In the first place, the chief items are so well made that they should, with fair treatment, serve on later visits. In the second place, those who go back home without any intention of paying a return visit, and who have therefore no further use for the tackle, should have very little difficulty in disposing of it by private sale to others similarly placed, to whom the listed price of a brand-new outfit seems exorbitant for so short a holiday.

III. Expenses on the spot may be roughly set down at seven dollars (just under 30s.) a day, including board and lodging, boat and guide, but with no margin for liquor or cigars. Bait costs a further sixty cents (2s. 6d.) a day, and it is usual to give a gratuity to the guide at the end of the trip if he has given satisfaction, not to speak of sundry small tips to the servants at the inn.

The one further item of expense is incurred through the ambition of everyone successful in his fishing to have at anyrate one specimen fish mounted by the local "naturalist," that he may 


\section{FLORIDA AND THE WEST INDIES 99}

present it to his club or hang it in his own billiardroom as a reminder of the sunny days and royal battles that he fought when he was young and full of adventure. For the fish-liar there are few wall decorations more encouraging than a tarpon, for to the eye accustomed only to the fishes of European waters it looks so huge that it will carry the imagination of those who behold it to the most desirable degree of credulity. The local charge at Useppa by Messrs Shaw \& Jack for mounting tarpon is about $£ \mathrm{I}$ per foot, and there are some extra charges for skinning and packing. The freight home is expensive, and by the time I had got a couple back to Devonshire, each measuring some inches over six feet, I found that they cost me not far short of $£ \mathrm{I} 9$. 
THE TARPON

\section{(Megalops thrissoides)}

BEFORE dealing with the details of its capture it seems desirable to say something of the little that is known of the tarpon's life-story. When an angling writer sets out to give a brief sketch of the natural history of any better-known form, of the salmon or trout or black bass, he has access to a mass of literature, scientific, descriptive, speculative, which he can easily reduce in the light of his own experience to an intelligible précis. Writing of the salmon, he has material in the interesting questions of its colour-blindness, its feeding (or its fasting) in fresh water, and its singular preference for some rivers over others seemingly as well suited to its needs. The trout and the black bass offer similar points of view, and indeed every fish of importance in the angler's diaries has for generations been the theme of an extensive literature, and experts with rod and pen, from Izaak Walton down to Professor Jordan and Sir Herbert Maxwell, have essayed to unveil the mysteries of its watery life.

The tarpon is in a different position. It is mysterious and unstudied. $\mathrm{Mr} \mathrm{C}$. F. Holder has devoted space to it in his delightful books, and it is the subject of many sporting articles in the American magazines and weeklies, but of literature, in the sense of salmon literature, it has little or 


\section{FLORIDA AND THE WEST INDIES IOI}

none. $\mathrm{Mr}$ Turner and $\mathrm{Mr}$ Rowland Ward have published books on the subject in this country, the former out of print, the latter brief and a little out of date, though excellent in its day. $\mathrm{Mr}$ Spencer Churchill has now recently produced a tasteful volume on the sport. In these books, however, of all the actual history of the great fish, from the egg to the gaff, only the last episode is treated in detail. What follows therefore is offered with some diffidence as the outcome of personal observation and of conversations with others who knew the fish in different seas, not only in Florida but also in the West Indies, where the tarpon is the more precious as a sporting asset by reason of the limited fresh-water resources which that archipelago offers to the fisherman.

That the tarpon is a kind of herring is evident from an even casual glance at the symmetrical body, deep cleft of the mouth, large round eyes (not, by the way, reproduced with fidelity by the average taxidermist), and blunt, upturned nose. For the most distinctive feature of the larger fish, the whip-like ray of the dorsal fin, the herrings of cold seas have no equivalent. The use or significance of this long fin-ray has not, so far as I know, been explained. When I knew the tarpon only in the museum, I used to think'that this might, as in the dragonet and some other forms, be a secondary sexual character, but as it was present in each and all of the seventy or eighty fish that came under my notice, I conclude (though I confess to having made no examination of their sex) that this is not the case, as they would hardly all have been males. It has been suggested that the ray may serve as a 
rudder in the rapid twists and turns that the fish must make in the water to elude its persistent foes, the sharks, but this remains pure conjecture and can scarcely claim the support of mechanical theory.

The large and beautiful scales which cover the body and head like greaves of silver armour are familiar as souvenirs, and make interesting objects for engraving on. Some of the largest measure four or five inches in their greatest diameter, and all have at one end a very decorative patch of silvering, which, when they are in position on the fish, alone shows, while delicately pencilled lines radiate over the surface from a point near the centre of the scale. The lower edge is scalloped, but the rest of the outline is unbroken. With care these scales keep well, but the edges show a tendency to curl, which makes them none too easy to write upon.

As in all herrings the tail is deeply forked, the lobes differing slightly in length as a rule, though not so conspicuously as in the sharks. In life, the gills are of that bright crimson which perhaps indicates rapid circulation of the blood, and they are particularly conspicuous as a tarpon leaps close to your boat and endeavours to shake out the hook. The roof of the mouth is exceedingly hard, and, as I have proved to my own satisfaction on dead fish, it is in some parts literally impossible to force the large hook in up to the barb.

The greatest length and weight attained by tarpon is even more a matter of guesswork than in the case of fishes that are the object of a regular net fishery. Those who follow Mr Ffennell's 
annual summary of big salmon, published in the columns of the Times, know that the heaviest specimens are taken in the nets and not on the rod. It is conceivable that all fishes would continue to be taken in nets long after they had grown too heavy or perhaps too wary to be caught on the rod, and it is therefore to the nets that statisticians look for records of big salmon. For the tarpon there is no net fishery. Even were there a regular market for its flesh it would be no easy matter to construct a trawl or gill-net capable of taking such huge fish in large quantities. We are therefore thrown for our records on the takes of anglers, in all probability an unsatisfactory guide to the truth.

So far as I know, the heaviest tarpon taken in this way scaled something like 2 ro lbs. $\mathrm{Mr}$ W. T. Hornaday in his large Natural History alludes to one of 300 lbs. (?), but without giving the source of his information. It is, however, incredible that so careful a writer should have named that figure without sound authority for the statement. As regards the fish of 2 10 lbs., I have been told that its weight was calculated from a generally-accepted formula, which will presently be given, based on the cubical contents, and that the "record" tarpon was never actually put on the scales. Without any wish to cast a doubt on the validity of the record, I will only add that of hundreds of tarpon weighed on the scales at Useppa and the Pass during a number of years, not one has approached that figure, Mrs Turner's best fish in 1902 ( $178 \mathrm{lbs}$.) being, I believe, the Useppa record to date.

The average fish captured in Boca Grande would be about 100 lbs. Rather more than twenty-five 
per cent. of those caught in 1906 exceeded that weight, and a little over six per cent. were less than the half of it. The heaviest scaled 165 lbs., the lightest, taken by myself, weighed but $18 \mathrm{lbs}$.

As regards the tarpon's greatest length, I imagine that a fish of 7 feet is near the maximum. The length does not bear a constant relation to the weight, a matter probably of condition. One of my own fish, weighing i 7 lbs., measures 6 feet 2 inches, and a second, weighing $140 \mathrm{lbs}$., is only two inches longer. These two specimens represent the two distinct types of tarpon met with in the Pass, a lean, racy type and a deep, heavy type. I do not intend to suggest by "type" that these in any way correspond with those local races of herring with which Heincke and other authorities have made us familiar by their researches in the Baltic and North Sea.

Of the natural food of the tarpon next to nothing is known. Even our Cornish fishermen at home, to many of whom hook-and-line fishing for mackerel is a means of livelihood for months together, know quite well that those fish take a strip of mackerelskin towed behind a sailing boat, but know absolutely nothing of their natural taste for copepoda and weed-spores. Those who catch tarpon for sport instead of gain are content with the same ignorance. They know that the fish will take six inches of mullet dangling from a hook. A few of them occasionally try to substitute a garfish or some other bait, but without, as a rule, much success. Of the tarpon's natural food, however, they know nothing and inquire nothing. It must be confessed that the excitement of the sport is 


\section{FLORIDA AND THE WEST INDIES 105}

such as to discount anyone's thirst for biological knowledge. Nor does the tarpon differ from the majority of surface-swimming fishes in the rapidity with which it digests its last meal. Of several that I cut open in order to ascertain the contents of the stomach, one only revealed anything, and that was a blue crab, measuring about six inches across the back, and the skeleton of a cow-fish four inches long. As the tarpon that furnished this slender material weighed $55 \mathrm{lbs}$., it looks (though anything in the nature of deduction from such meagre data is out of the question) as if this fish may, like the herrings of other seas, prey on forms of life very small compared with its own bulk.

In character, the tarpon displays, like some other large fishes, a curious mixture of foolishness and cunning, of ingenuousness and resource. The guileless impulse with which it takes a strip of fish dangling from a great tinned hook, which the fisherman does not take the smallest pains to conceal, can only be explained by its want of education in the angler's ways. We at home are accustomed to the curious familiarity with the wiles of man displayed by the trout that dwell in much-fished waters. Even the salmon, whose way of living takes him during part of the year out into the sea world and beyond reach of nets or hooks, loses familiarity with those engines of destruction, but the old trout of the chalk stream sees, every mayfly season, so many clumsy flies pitched before and behind him that only the artist can compass his fall.

The tarpon is denied the obvious advantages of so liberal an education. Even off Colon and other 


\section{6

ports of call on the Spanish Main, where there is continuous traffic of merchant shipping, and where doubtless, frequent efforts are made to tempt them with "bully" beef and other baits, I have known tarpon show far more suspicion than in Florida. The brief annual season, lasting five or six weeks, cannot possibly teach them the danger of fishingtackle, and so the crudest deceptions succeed. In a splendidly-illustrated book on the game fishes of Florida, now out of print, $\mathrm{Mr}$ Turner some years ago predicted that the tarpon of Boca Grande would in the near future learn to fear the gifts of the Greeks, and that the Greeks would in consequence have to invent new deceits. That forecast is no nearer fulfilment than when it was made, for luck and muscle still win the game, and tarpon strike as freely as ever. Thanks to mosquitoes and the growing power of the sun, the season ends with May. Thanks to the unwillingness of the fish to take a bait with any freedom before the end of April, it does not therefore last much more than a month. Even during that short period new tarpon are continually coming in from the Gulf, many of which may never have seen a hook. Fortunately, the tarpon is in no danger of exhaustion, for it has no market value and is not therefore caught for commercial purposes, having, during most of the year, no enemy more formidable than the sharks, which it can easily outswim.

Once hooked, the tarpon's carelessness vanishes. Threatened with shipwreck, it dies as befits a king. As often as not, indeed, it does not at the moment die at all, but makes good its escape with a mixture of strength and cunning very exhilarating to its 


\section{FLORIDA AND THE WEST INDIES IO7}

adversary. Danger and difficulty brace it in its efforts to regain the liberty it so foolishly flung away, and it plays so good a losing game as often to snatch a victory when almost on the beach. Its trick of jumping many times out of the water, which may, of course, be only the result of pain, is alone enough to disconcert a fisherman unused to such displays. Unless on the hook, it does not jump, though I have seen tarpon in their hundreds rolling and wallowing at the surface like great carp in a stew. Nor does this untaught child of the Gulf lack any of the tricks known to trout and salmon: the fit of sulking, the sudden rush, the often fatal ruse of doubling on its tracks, charging towards the boat and then, in a moment, dashing off at an angle, in short, all the tactics that the fisherman might expect from a foe that had known the rules of the game all its life.

Something was said above of a simple mathematical formula for obtaining the approximate weight of a tarpon from its cubic measurement. Obviously such a calculation could be made only from a perfectly symmetrical fish, and would be quite unreliable in the case of the asymmetrical eel or turbot. It is as follows :-

\section{$\frac{(\text { extreme length in inches) } \times(\text { extreme girth in inches) }}{800}$}

The length is measured from the tip of the snout to the median point of a straight line drawn at right angles through the end of the shorter lobe of the tail.

Whether this method of reckoning weight from measurement would satisfy the President of the 
Institute of Actuaries I have not inquired, but it is worth sacrificing a little accuracy (not more, I dare swear, than we cheerfully lost on the Useppa scales) in order to save the fish for another fight. This was formerly done at the Pass, and is still, I believe, the practice in Texas and at Tampico, the gaff being dispensed with and the fish handlined to the beach or boat. At Useppa, on the other hand, they first kill the fish and then waste it. Dozens of splendid tarpon are towed back to the inn each week to be weighed. Of these, one or two at most find their way into the hands of the "naturalist"; the rest are towed back again and cast adrift next morning to feed the sharks or pollute the water until crabs and catfish devour them. The Scripture tells us that "The slothful man roasteth not that which he took in hunting." I do not say that there is any mandate to eat tarpon, since it is regarded by so many as practically unfit for food, and if anything is condemned for the table in Florida I should say that it must be pretty bad. Whether it actually is suitable for the table I do not know. The cook at Useppa Island was not the magician to work miracles out of such questionable material. Yet we used also to throw away the large jewfish taken daily on the tarpon grounds, whereas a huge specimen, weighing over $300 \mathrm{lbs}$, which I saw at Port Tampa, was taken to the icehouse for sale to local restaurants. Nevertheless, if we cannot eat our tarpon there is no need to kill them. A fish that is useless dead may well be spared.

The geographical distribution of the tarpon, on which much has yet to be learnt, is not, I think, 
fully grasped by those who refer to the fishing as if it could be enjoyed only in the States of Florida, Mexico and Texas. It is true that Boca Grande, Tampico and Aransas have hitherto been the chosen spots for tarpon-fishing, and it is also not to be denied that the conditions in those localities are particularly favourable to anglers. At the same time the tarpon has an immense range round the Caribbean, occurring on the coasts, in the rivers, and even in landlocked lagoons of practically the whole West Indian Archipelago. It is also met with on the eastern shore of the Atlantic Ocean, for sportsmen stationed on the West Coast of Africa have often hooked a tarpon, though, owing to faulty tackle, rarely succeeded in catching it. Unlike most herrings, which thrive best in cold seas, the tarpon is a fish of the sunshine. With few exceptions (like the smaller mackerels and mullets) the distribution of a sea-fish is generally proportionate to its size. The largest sharks and their vicarious forms range all over the waters of the globe. That gigantic mackerel, the tuna, or tunny, is well known in the Mediterranean and in the bays of California. It is plentiful around the island of Madeira at certain seasons of the year. I had always regarded it as a warm-water fish, but have lately been informed by an officer in the Navy that he has caught it in nets on the coast of Newfoundland.

Of the tarpon's breeding-time and season of migration very little is definitely known. The spawn has not, I believe, been identified, so that we have no information as to whether it sinks like that of the herring, or floats like that of the 
pilchard, both cousins. I am indebted to $\mathrm{Mr}$ Bertram, Auditor-General of Jamaica, for the interesting information that baby tarpon are found in landlocked waters in the West Indies. $\mathrm{He}$ has met with them in many ponds in Westmoreland (Jamaica) and also in the lakes of Antoine and Levera in Grenada. This must obviously be the work of waterfowl, which are known to carry the spawn or fry of various fishes entangled in their plumage and feet. Mr Bertram also told me that tarpon up to a weight of fifty pounds may, after heavy rain, be caught in the Black River and Milk River (Jamaica), and that when "whitebait," the young of the white-banded herring, is obtainable for bait, much heavier examples are taken off Port Royal.

Whether, like the majority of the herrings, the tarpon is a restless wanderer is not known, for it has hitherto been studied only during its summer sojourn in the Passes. Mr Leicester, keeper of the lighthouse on Gasparel Island, Boca Grande, a most intelligent and observant man, who has lived on that island for years, told me that he had seen tarpon in the Pass all the year round, though he noticed both larger individuals and greater numbers during the warmer months. Unless some undetermined change in temperature or other conditions of the atmosphere and water prompts the larger examples to show themselves more at the surface in the summer, it is reasonable to regard their presence as the result of migration.

But all the tarpon's life-story is enveloped in even greater mystery than that of the salmon. The latter is, it is not to be denied, a baffling 


\section{FLORIDA AND THE WEST INDIES III}

subject, owing chiefly to its mysterious sea-going habit, for when it takes to the salt water it passes entirely beyond our ken and returns so altered that we have the greatest difficulty in recognising any but the few marked fish that have from time to time been recovered. The tarpon, as has been said, is not a marketable fish, and has therefore been overlooked by those who make a study of economic ichthyology. Apart, however, from its value as an asset in the tourist resources of the State of Florida, it is supremely interesting as the most splendid living connection of what is perhaps the most commercially important family of fishes in the world. It is, therefore, to be hoped that before long some of America's distinguished marine biologists may turn their attention to its life history and bring light to our darkness. 
Something has already been said of the extremely strong tackle used in tarpon-fishing. When it is mentioned that a boy of under thirteen years of age has been known to kill a tarpon of over six feet long, and that ladies have killed some of the heaviest fish on record, much of the result must obviously be conceded to the leverage of the reel and strength of the tackle generally.

The rod, which measures in all about seven feet, is made of hard wood, in two pieces, a short butt of twenty-two inches and a "tip." The butt is fitted with German silver and has an excellent grip bound round with fine cane. The rings are large and upright, and the top ring is particularly calculated to let the line run with as little friction as possible. Beyond combining great strength and little play, the modern tarpon-rod has nothing very distinctive about it. It looks powerful enough to hold a runaway team of horses harnessed to a fireengine, but I have seen sharks break the tip like a spelican, and I once saw one of these rods actually go in the butt just as the fisherman had got his tarpon to the beach.

The reel, by far the most important item of the equipment, is a wonderful piece of mechanism. The chief fault about even the best English reels designed for the same work is extreme bulkiness. The Ameri- 


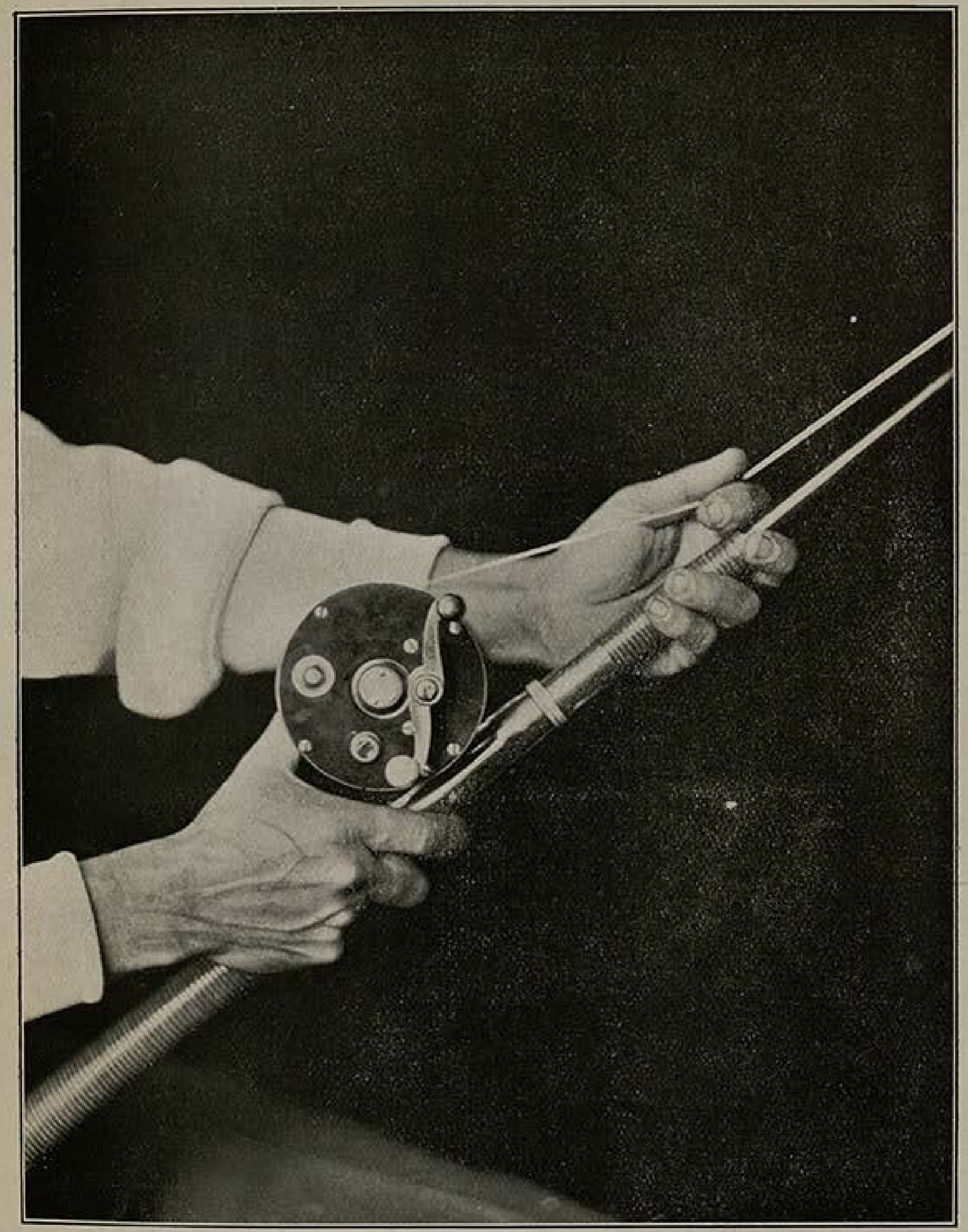

To face page $\mathrm{I} 12$.

CONTROLLING THE BRAKE. 
can tarpon-reel, which does everything that can reasonably be demanded of it, is not more than four inches in diameter, yet comfortably takes two hundred yards of strong line on the barrel. It is furnished with very powerful multiplying gear, as well as with three brakes or drags; one at the edge, a second to prevent the handles revolving when a fish pulls line off the reel, and a third, of leather, which the right thumb jams against the line on the barrel, constituting a very powerful check on the fish. This wonderful reel is light and strong and as perfect a reel as I ever used anywhere. Its one drawback is its high price. Nine sovereigns for a reel may to many seem ridiculous. Before I had used this reel of Vom Hofe's against tarpon, $I$ thought it so myself. Now I know that if he asked twice the price for it he would have to have it. On the strict basis of cost of production it could no doubt be placed on the market much cheaper, but until someone else has either the effrontery to infringe his patents or the inventiveness to improve on them, he, as the sole maker, will continue to ask and get the present price.

The line, an undressed twist, is no stouter than we use at home for large pollack only a tenth of the tarpon's fighting weight. It is not, if the truth must be told, miraculously durable after use in salt water. In all probability, however carefully they may be tested before leaving the works, these lines vary in quality. On one I killed about $500 \mathrm{lbs}$. weight of tarpon, not to mention other fish, in one week. On another I killed nearly $600 \mathrm{lbs}$. weight in another week. On the other hand, a third line was rejected after breaking twice in one 


\section{4 SUNSHINE AND SPORT IN}

day over fish of no great size, and, in fact, caught only three tarpon weighing under $100 \mathrm{lbs}$. in the aggregate.

The sinkers weigh $\frac{1}{4} \mathrm{lb}$, or, in some cases, $\frac{1}{2} \mathrm{lb}$., and tarpon-fishermen get through a number of these (at a $\frac{1}{2}$ dollar, or $2 \mathrm{~s}$. Id., the box) through a silly fashion of fastening them to the top of the wire snell with very fine copper wire supplied for the purpose. It is contended that, unless the tarpon throws off the sinker at the first jump, the inertia of the lead will help it to get free. If I sold these sinkers, this would seem to me admirable reasoning, for it increases the demand for them incalculably, since not alone every tarpon, but also every shark, grouper, or kingfish knocks off a sinker attached in this way, and the fisherman favoured with many strikes can easily use a box of them every day. This adds considerably to the cost of an outfit already sufficiently high, but, as a matter of fact, this slender fastening of the sinkers is quite unnecessary. I am sure that the man who sells the sinkers, for whom I have a warm regard as a good sportsman and genial companion, has too keen a sense of humour not to appreciate the fact that, passing one morning very close to his boat, I noticed that he fastened his own with line. This I immediately imitated, and found that in a few cases the mighty jerk of the tarpon's head snapped even the stronger attachment and threw loose the sinker all the same, and that yet more often the sinker kept its place and I got the fish to the beach in spite of its supposed help. When we come to think of it, how should four or five ounces of lead make any difference to the weight of a leaping fish 


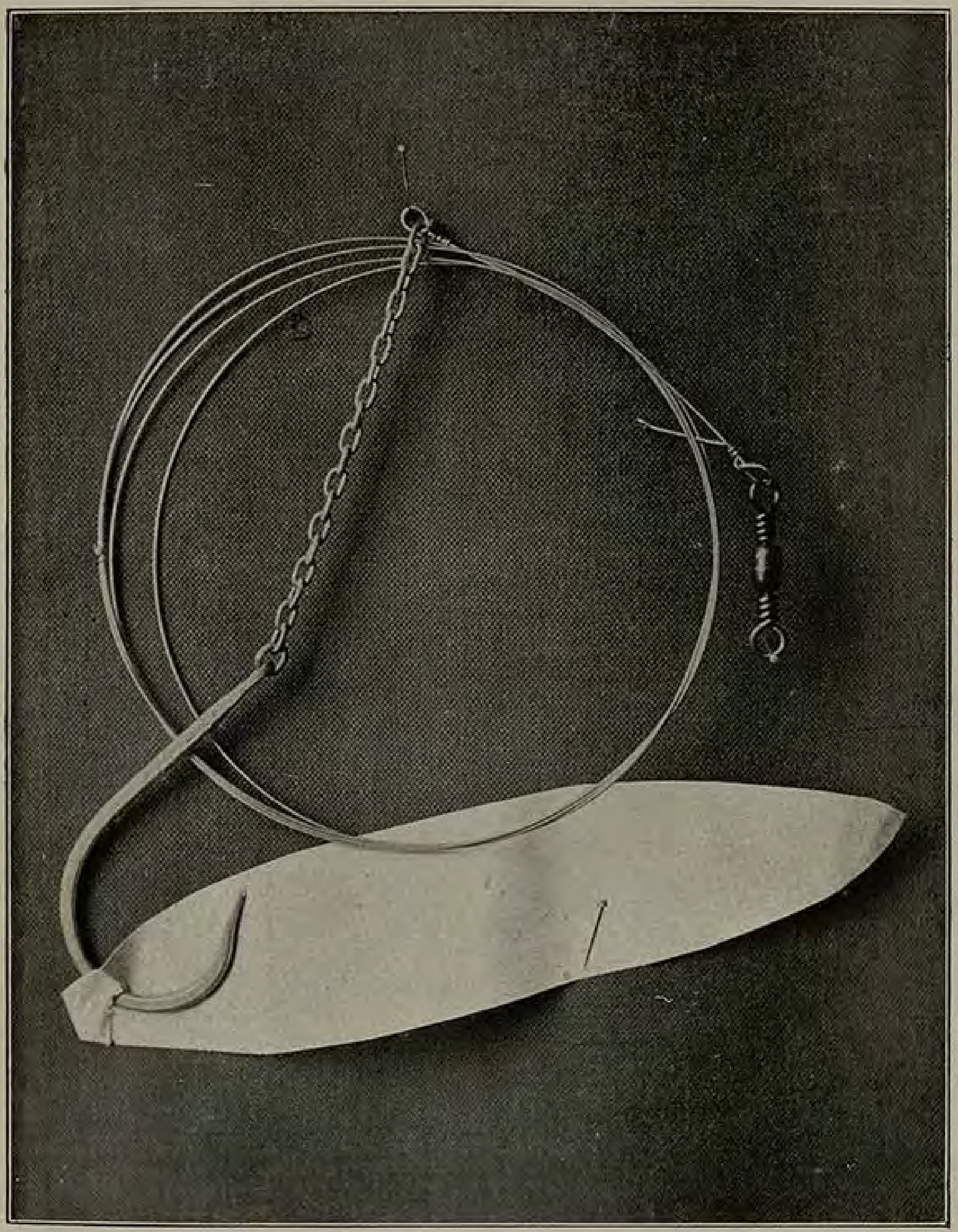

TARPON HOOK AND SNELL.

(The parchment is cut same size as the bait of mullet.)

To face page 114 . 


\section{FLORIDA AND THE WEST INDIES}

weighing $100 \mathrm{lbs}$.? The theory is ridiculous, and it would be quite as reasonable (if not, indeed, more so) to suggest that the extra drag of the sinker serves to keep the hook buried in the tarpon's mouth. In either case, the part played by the sinker, for the fisherman or against him, is a negligible quantity.

The tarpon-hook, which shares with the majority of tinned hooks the fault of bluntness, and which might, with advantage, be a little sharper, is, as shown in the photograph, attached to a snell, or leader of piano wire, with a few links of chain, the object of the latter being to take the sudden brunt of the tarpon's leap, for without such flexible intervention the wire might snap at a kink. The object of so great a length of wire is not, I imagine, to offer the hook on fine tackle, but rather to provide against the line fraying on the back of the fish, particularly when, on being towed into shallow water, it twists and turns, dashing to right and left in frantic efforts to regain the deeps. As a matter of fact, this wire is a drawback when sharks seize the bait. Were the hook attached to something with less resisting power, the shark would merely bite through it and solve the difficulty; as it is, the fisherman, loth to lose much line, hesitates about cutting the brute loose and wastes much valuable time. In "still" or gorge fishing the chain is dispensed with and the hook is attached to a leader of raw cowhide. When the hook is buried somewhere deep down in its vitals the tarpon has little chance of throwing it out.

When seen for the first time in the Fulton Street Store, there is an article of the outfit that 
looks insignificant and uninteresting, but I am convinced that without its aid it would be most tiresome, if not often impossible, to win so great a fish from its lair. I refer to the leather rod-rest for clamping on the fisherman's armchair just between his knees. It resembles in shape and size a breakfast cup, and as soon as the fish is fairly hooked the fisherman slips the end of the butt into it, thereby gaining a tremendous leverage, so that he can alternately raise and lower the top and reel in the slack thus obtained. But for this ingenious device the rod would almost certainly be snatched from his grasp at the first jump of so prodigious an acrobat, and the fatigue of reeling it in while under water would be incalculably greater, while the tip, having in that case to rest on the gunwale, would probably break under the heavy strain. A somewhat similar rod-rest is made on a belt attachment, which the fisherman is supposed to gird about him when he steps out of the boat to clamber up the beach and play his tarpon to the gaff. Personally, after one or two exceedingly disagreeable experiences of this manner of applying the closure, I preferred to remain in the boat. Had I, at the outset, known this to be by far the more comfortable method, I should not have purchased the belt at all. Even on its best days the Gasparel beach is not adapted to this manœuvre, and when, after a spell of wind, the sea has washed most of it away, the fisherman has to behave like a fly climbing up a wall, only the fly has special feet for the job and has not got to pull a hundred-pound tarpon after it.

The gaff, which has nothing remarkable about 


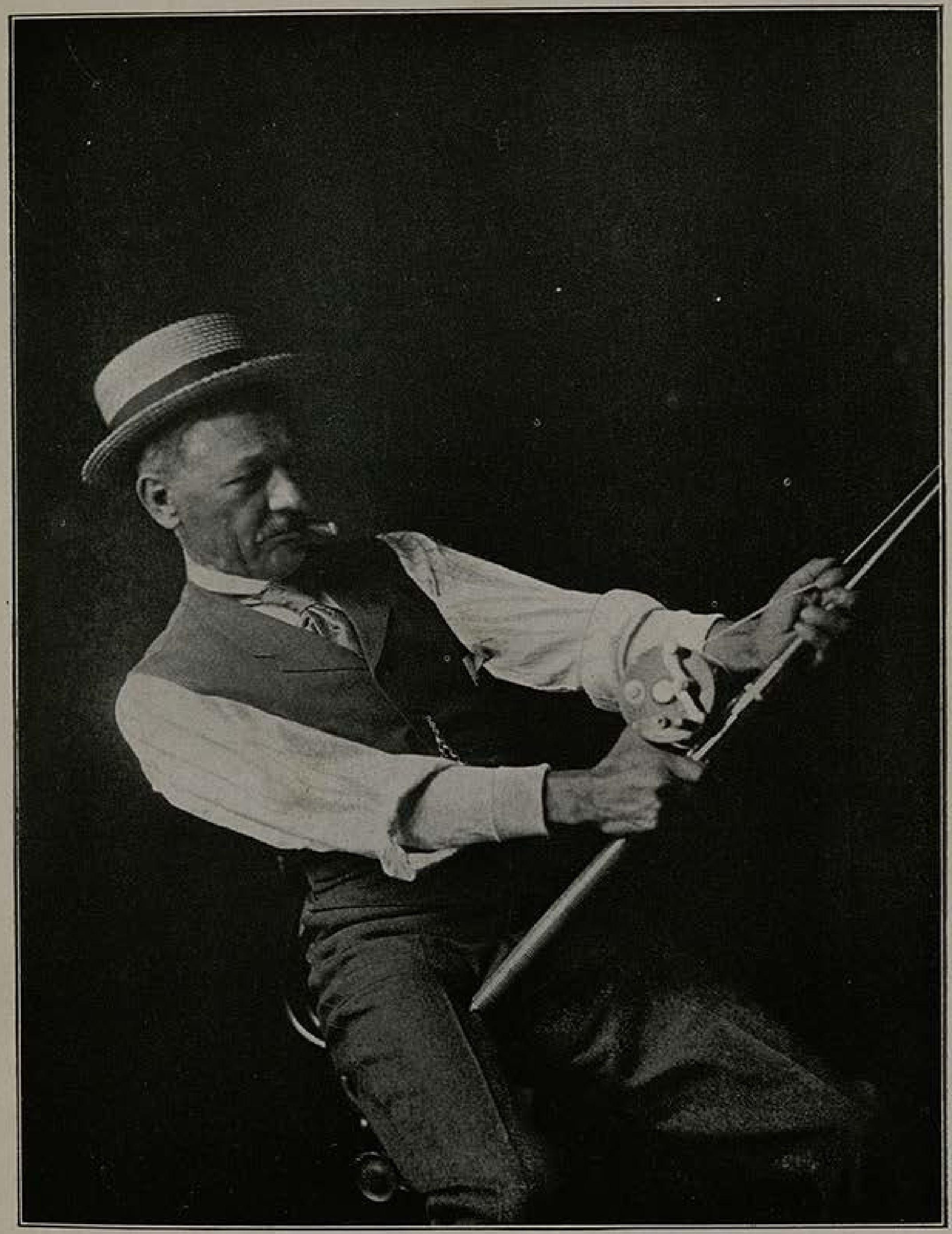

To face page II 6.

WHEN THE TARPON JUMPS. 
THE bait invariably, or almost invariably, used at Boca Grande is a strip of mullet measuring from four to six inches, according to the fancy of the guide who cuts it. It is about the crudest lure I ever saw palmed off on so fine a fish. Infinitely more trouble is taken at home in baiting a hook for a six-inch roach. Even in our seas no bass or whiting would barter its freedom for such a bait. True, in Cornwall we use a similar strip of pilchard, or chad, for pollack, but the hook is much smaller and is buried in the bait. In tarpon-fishing it is most conspicuous.

Yet so long as tarpon continue to take an interest in a fraud so patent as hardly to merit the name of treachery, there is no need to try anything else. $\mathrm{Mr}$ Turner's educated tarpon, which have gathered the fruits of adversity, and dread every hook after one prick, have yet to visit Boca Grande. At present the glorious tarpon dashes at the silver strip of mullet wobbling in the bright water as if there were no such thing as fishermen within miles. Perhaps, for all we know, this silly fish may even take the tin gleam of the hook for part of the mullet's skin.

Every morning the mullet, six for each fisherman, are purchased at ten cents apiece from one of the Spanish colony settled on an island near Useppa, 
who earn their living in this way all the season. The guides cut up the mullet on the way down to the Pass as they are towed behind the launch, four baits from each fish. This brings the bait bill up to a sovereign for every eight days' fishing, which in England would be reckoned exorbitant for anything but live bait, but which in America is paid without a murmur. If I remember my school textbooks of political economy right, this is known as a "high standard of living." It may be admirable for those who are paid on the same scale, but to earn your income in Europe and spend it in America is not humorous.

In Texas I believe that a whole mullet is used for bait, but this does not answer in Boca Grande. On the other hand, some sportsman with original ideas now and then tries a different bait. One American of the party occasioned a good deal of amusement last season, to everyone but himself, by insisting on using small garfish, which his coloured guide caught for the purpose from the beach. For several days he caught nothing but kingfish, which have a passion for "gars." Then he threw his originality and his garfish overboard, and used mullet as successfully as the rest of us.

Mullet bait answers best when perfectly fresh, and in all but the worst weather the Spaniards supplied it with unfailing regularity. Now and again it happened that they could not shoot their nets, and then we had to use stale bait, on one occasion three days old. There was, I remember, some hurry to get it out of the boat, but it caught tarpon as well, or almost as well, as the fresh, and, so my guide told me, would continue to do so as 
long as no one else fishing in the vicinity offered the tarpon anything fresher. This proves the tarpon a philosopher, capable of contenting himself with the best that life offers at the moment.

The preference for mullet bait at all American centres of tarpon-fishing is not echoed in the West Indies, though mullet is also used there.

Fly, prawn and the local "white bait" already mentioned are all used with success in Jamaica.

The bait used in "still-fishing" consists of almost the whole mullet. 
THE METHODS OF FISHING

\section{Pass Fishing}

ONE day in the Pass seems much like the other, though a closer reference to my diaries allots to each its episodes. My last day of all, r6th May, was as interesting as any, and my journals furnish the material for a fairly close description of its fortunes.

At six of the clock seven fishermen are called by Clifford, the coloured porter at the inn, and straggle, viâ the bathroom and breakfast-table, to the launch. By seven Commander Hasen has coaxed that wayward craft to move a little sooner than usual, and seven small boats, each occupied by a guide busy cutting up the day's bait, are towing in the wash astern.

The morning is perfect. Not a breath of air ruffles the smooth surface of Charlotte Harbour. Pelicans paddle in the shallows as they might in St James's Park, and every now and then one of them dips his landing-net under a baby mullet that has swum within its reach. In the launch the conversation, for a wonder, is not tarpon. The vagaries of the engine have produced a heated discussion between one of the party, who knows something of motor-boats, and another, who thinks that he knows a little more. A gallant officer, who raised his own men for the fruitless war against 
the Boer, is commenting on the prospectus of the newly formed Frontiersmen's League. Two others argue over the merits of two kinds of camera. Gradually, however, these interests merge in the business of the day. The conditions are ideal. We are timed to hit the slack tide to a minute, and there is no wind to make the skiffs dance as merrily as they did the other day, with the result that nine tarpon out of every ten got free, for the fisherman cannot attend to two things at once when one of them is a tarpon fighting for its life.

As we near the Pass, we run by a yacht, a houseboat and a couple of traders loading phosphates, and here, facing the open Gulf, we are conscious of a light breeze, a zephyr, no more, blowing in from the sea, just sufficient to soften the scorch of the sun and not enough to disturb the surface of the water, already broken by the roll of many fish.

The vessels are just swinging to their anchors, which shows that we have caught the slack at the right moment, and, as the tide will soon be turning in, the launch gives us a good drift by taking us well down the Pass abreast of the sandspit before turning us loose. On the near shore we see a small band of turkey-buzzards strutting round some fishy jetsom that must have escaped the eye of Leicester, who is generally watchful that all dead fish are cast adrift from his domain. But something of a hundred pounds or so has been deposited within reach of the little vultures, which are greedily tearing off long strips and gorging them with disgusting despatch. 


\section{FLORIDA AND THE WEST INDIES}

At last the engine stops, the launch glides smoothly to rest, and the guides, having cast off the tow rope, paddle quickly alongside. Each fisherman steps into his own boat and sits down in the comfortable armchair clamped to the after thwart, back to his guide and facing the stern. Out of regard for my shortness of leg Underhill has thoughtfully provided a well-filled sandbag in the stern, which gives me better purchase during the "pull devil, pull baker" game of the day.

The seven skiffs spread out, the hooks are baited, the sinkers swung over the side and fortyfive feet of line (by a mark) allowed to run off the reel. Then the drags are switched on, the left thumb presses a turn of the line against the butt, the right jambs down the leather brake on the line, and the decks are cleared for action. The butt is not rested in the leather cup until a fish is hooked, but is held down, the tip protruding over the gunwale, a little to left or right, so that the fisherman does not impede the guide's view of it. To the practised eye the movement of the tip conveys a good deal of what is going on down below ; and, from watching it, the guide knows just whether to row ahead, back water, or keep the boat just where she is. I had so long been accustomed to learning the movements of bass at home in the same way that it came easy in the Pass.

When, for the first time this morning, I glance up from my own rod, it is to see the bending of R.'s, who, as usual, has hold of the first fish of the day, a feat that he has repeated with monotonous regularity for more than a week. This morning, however, it is a case of the cup and the lip, for he 
loses his fish at the first jump. Not five minutes later he is fast in a second before anyone else has a touch, and this time the fish jumps twice, the second jump very near my boat, and his coloured guide, as smart a boy as any of them, sets his powerful shoulders to the work of pulling for the beach.

What was that? My eye is back on my own rod. The merest twitch; a tremor that could have been caused by a roach, but that has not escaped the watchful eye of Underhill, my guide, who whispers to me to look out. I do, and next moment the twitch comes again, and I strike again and again, jambing the hook home in the hard mouth at the other end with all the strength I have. Then line flies off the reel at such a pace that I am able to slip the butt in the rest and wait results.

"Make him jump!" sings a wag from a neighbouring boat, and indeed, before I have any say in the matter, up go five or six feet of molten silver in the sunshine, and back comes the line, hook and all, as the tarpon falls free.

"Bad luck!" comes from the "Gee Whiz," and-

"Oh, help!" and the occupant nearly drops his monocle as an immense tarpon dashes out of the water half-way between us, and his reel sings murder. Without much fuss the fish puts fifty, then a hundred yards between them, giving three more splendid jumps between. That looks like the fish of the year, and off goes "Gee Whiz" into the middle distance and out of my thoughts, for there is a fresh bait on my hook and I have other fish to fry. When I next encounter "Gee Whiz," the 
sportsman sitting on the stern pulls a long face, and it transpires that just as he was getting his fish, "a nailer," to the beach in a state bordering on exhaustion, a great shark tore it off the hook.

And now I am once more fast to a tarpon, nothing of great size, but at any rate firmly hooked. Up he comes, then plunges wildly down the Pass. Up he comes again, also without avail, shaking his massive head like a bulldog worrying a bone, then dashes straight for my boat. Underhill pulls madly for the shore as I reel in the slack, but the tarpon is too well hooked for such tricks to serve him. There is another jump, after which, braced perhaps by the fresh air, he gets another twenty or thirty yards off the reel, and Underhill rests on his oars so as not to throw too heavy a strain on the line. These medium-sized tarpon always give you a better fight than the heavy fish, a distinction that I have also noted in bass and other fish at home. We are near the beach now, and one other boat is pushing off, leaving a gleaming tarpon high and dry on the sand, and another is aground on the shallows, its occupant playing a fine fish, while the coloured guide hops to and fro, the great gaff ever poised for the stroke, but again and again eluded by the tarpon's frantic dash for deeper water. Our own keel grates on the sand, and Underhill is over the side and at the first thrust manages to drag out of mischief a tarpon that looks about $80 \mathrm{lbs}$.

On our way back to the fishing we pass the Colonel, smiling grimly under his broad-brimmed "dolly varden," his rod bending like a reed, his line running out like the line of a rocket going to a foundering ship. Up it comes for a last jump, and 
it proved that evening to scale 145 lbs., a goodly fish destined for a London club.

This is a day of days. Before we have fished an hour everyone has a fish on the beach, a rare achievement so early in the day. "Gee Whiz," still smarting under the larceny of the shark, is consoled by a fish of $100 \mathrm{lbs}$. $R$. has one that should be well over 120 lbs., and three or four others going 80 lbs. and $90 \mathrm{lbs}$. are drawn up in the shade beneath the little pier.

One only of the stranded tarpon is mine, but the morning has been a busy one in our boat, for Underhill has gaffed and thrown back a couple of jewfish, each probably over $50 \mathrm{lbs}$, three kingfish between $15 \mathrm{lbs}$. and $20 \mathrm{lbs}$. apiece, which seized the bait with royal determination close to the surface, half a dozen ugly groupers about ro lbs. each, and a cobia (pronounced cawbya) of about the same weight. It has the colouring of a codfish and the fighting pluck of a bass, with a trick of hanging round the boat and snatching any bait that dangles over the side. This often means a smash, but this time the cobia came safely to the gaff.

After an hour or so of such fishing, catching every few minutes something which at home would be reckoned a grand fish, but which in the vocabulary of the fastidious tarpon-fisherman counts only as vermin, I strike something appalling. It makes no move, but its mere weight almost pulls the rod out of my hand as it sinks slowly to the bottom, and the strain on my line suggests the pull of a vessel on her anchor. For a second or two we hold our breath. There may yet be a jump, and if there is, and if all goes well, we have something very near the 
biggest tarpon ever caught. Alas! a minute goes by ; two; and now we know that, whatever it may be, this is no tarpon. Then a strange thing happens. The fish makes no attempt to get line off the reel. Great souls suffer in silence, and this one is singularly undemonstrative. But the boat moves off steadily through the water, heading for the opposite shore. The fish takes us in tow at this same steady pace for an hour-for two. First it heads for the open sea, which is fortunately in its calmest mood, and gets us clear of the Pass. There is something so grim about the whole performance that I cannot, for all my annoyance, help laughing at the nonchalant, way in which Underhill has shipped his oars, crossed his legs and lighted one of my cigars, looking the picture of uncomplaining ease, as he declares that he has no use for honest toil so long as he can earn his pay like a gentleman.

There is no longer any doubt in our minds as to the identity of the Unseen : it must be a shark, and a great shark at that. Suddenly, without warning, it turns abruptly up the Pass and tows us past the Quarantine station. Twice only during the first ninety minutes does it pull line off the reel, twenty feet or so at a time, irresistibly, but without greed. By this time we are nearly a mile from the nearest of the other boats, and the whole fleet is watching our eccentric voyage with great interest, timing us, calculating our slow but steady pace, and generally basking in the luxury of watching another in difficulties. Towards the close of the second hour, without any sign of relenting on the part of the shark, I suddenly tire of this aimless gliding through 
the water. I came all this way to catch leaping tarpon, not to be towed about at the pleasure of grisly sharks, and, caring little now whether the line breaks or holds, I suddenly alter my tactics and give our friend's jaw a wrench that tickles him and makes him pull fifty yards off the reel. He is tiring, though, and I succeed in getting line back on the reel even to the 45 - $\mathrm{ft}$. mark; ten feet more; the water is clear, and we should soon get a sight of him. We do. Underhill and I have been craning our necks over the side, and we simultaneously draw back with exclamations more or less profane (his more, mine less) as we see immediately below us the blurred outline of an enormous fish, distorted by refraction to the image of something far longer than the boat which it has hauled through miles of water. Why so immense a creature does not run out the whole of my 200 yards of water and then go on its way, this is a mystery, or rather would be did I not know the cowardly nature of these ocean bullies. They know not their strength and submit to coercion rather than show fight. Is this not equally true of many animals of both land and water? Do we not see the sparrow chase the hawk, the gull drive the gannet? When Benjamin Franklin called the vaunted American eagle a "lousy coward" (I quote him from memory, but this was the purport of his criticism), he knew what he was talking about, and it is a pity that his nation did not rather take for its emblem the splendid buffalo, then equally characteristic of its landscape and as symbolical of liberty until the greed of man made offal of its herds. 


\section{FLORIDA AND THE WEST INDIES I29}

Had the monster under our keel but guessed its strength, not for ten seconds could I have kept it on so short a rein, much less brought it closer to the surface. But, true to its nature, it preferred its bondage, and at last there was evidence of its tiring. There was even more evidence of my own exhaustion, and I tell Underhill that the end must come, whatever it is, before I loose hold of the rod. $\mathrm{He}$ therefore reluctantly gets out the oars and pulls slowly for the beach. That is to say, he puts all his weight (which is not much) into the job, but the boat, which ordinarily would fly through the water, makes about a yard a minute. It is like towing a yacht with the dinghy. We are passing near the flotilla, and I sing out to an American in the nearest boat to bring along his "gun," since there can be no gaffing such monster until it has a pound or so of lead in its skull. When we are still within twenty or thirty yards of the shore, I get the shark alongside, almost at the surface, and, as its length tallies exactly with that of the boat, we know that it must measure just $14 \mathrm{ft}$. In depth it appears to measure, so far as we can see, quite $6 \mathrm{ft}$., which means an immense displacement. Judging therefore by a far smaller example of the same species, known thereabouts as Leopard Shark, and not unlike a brindled porbeagle, which was got to the beach last week by the doctor on a yacht, and which scaled just over $300 \mathrm{lbs}$., Underhill puts this one at nearer $\mathrm{I} 200 \mathrm{lbs}$. than $1000 \mathrm{lbs}$. In comes the line, an inch or two at a time, everything strained by the great weight of the fish to the verge of breaking. As, in no more than a couple of fathoms of water, it finally comes to the surface on one side of my boat, the 
skiff containing my American ally shoots out on the other. His "gun," at full cock, swings pleasantly to and fro across my face. The sudden arrival of reinforcements apparently urges the shark to one last exhibition of its strength, and it does what it might have done much sooner and without half the risk. It smashes my rod-tip as I should break a match. Bang goes the revolver, and bang, bang again, as its owner discharges it at the water, but without harming the slowly sinking fish, though the second bullet must have severed my wire snell, as it came back in a coil to the broken tip. As luck would have it, the harpoon, which we had taken out on several occasions in fruitless search for a sawfish, was left behind that day, so we had to gaze helpless at the exhausted form of the shark, lying in the full blaze of a sun that left no secrets in such shallow water, and to leave the grisly tyrant to recover and thereafter to terrorise the coral underworld of Boca Grande.

As soon as the curtain has rung down on this fishy drama, I repair to the shadow of the lighthouse, there to find condolence, sand-flies and a repast the reverse of Amphytrionic, one in which appetite does not come with eating. Even the "Anheuser Busch" is tepid compared with the delicious draught of rain-water from a great butt beside the keeper's house. Two of the party have gone to lunch on the houseboat, and their tardy reappearance, an hour after the rest of us are afloat for the afternoon tide, suggests several rubbers of unconfessed bridge. Your true Englishman will have his bridge, even if he goes five thousand miles to play it in sight of the alligators that bask among the Keys. 


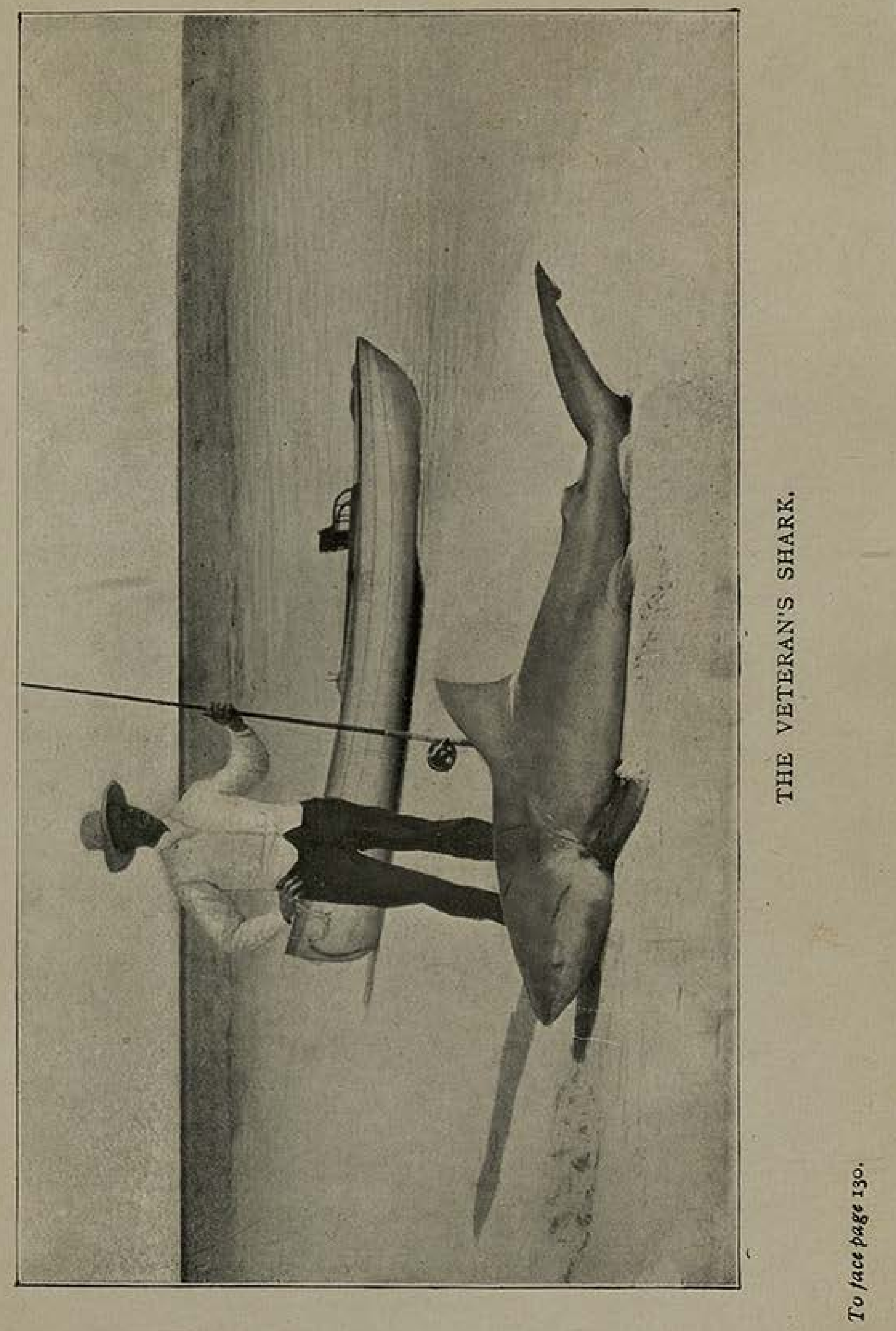


The tarpon are very much in evidence this fine afternoon, feeding with a vengeance. If we had no appetite for lunch, they are of another way of thinking. Three fish I lose in rapid succession, and this before any of the others get a strike. Two leave me at the first jump, the other at the second. I forgot to mention that the owner of the gun very kindly lent me a spare tip, with which to finish my last day's fishing, and I think that this was perhaps a trifle more elastic than that to which I had been accustomed. Hence perhaps my failure to hook any of the trio that set the ball rolling that afternoon.

Before I get my fourth, three other sportsmen are into fish, two of these looking, so far as one can judge from the brief sight of them in the air, well over the 120 lbs. mark.

I begin to bemoan my maladroitness. Underhill hangs on my words with the unconcealed admiration that only a son of Florida can feel for profanity. Slap! Bang! This one at any rate is no minnow, nor was it necessary to strike him, for he is up in the air like one of the angels in the Old Masters (angels of about the same weight), and the line runs off in coils before I get the butt home in the rest.

"A dandy!" says Underhill, and so, indeed, my customer looks in the one brief glimpse I get at close-quarters, for his next jump is a good hundred yards away. And still he takes line, but at last I get a move on him, and it comes in suspiciously smoothly, suggestive of the fish charging our boat. No sooner, however, has Underhill got way on the skiff for me to reel in the slack than the tarpon is 
up in the air again, down to the bottom, all over the place at once. At last we gain ground and head for the beach, and there is little further opposition until the boat grounds and Underhill jumps out, gaff in hand. Then the very devil enters into the tarpon. I am left in the boat, both thumbs, one of them numb with rheumatism, jambed against the leather brake. The fish, seeing white water and divining danger in the shallows, goes off, as a hunting friend would say, hell for leather, out into the deep water. Seventy or eighty yards of line it gets off the reel, and I, handicapped by my sick thumb, am powerless to stay the rush. The maddened fish has things all its own way. This is the moment at which some fishermen gird on the belt and, planting the butt of the rod in the socket just over the pit of the stomach, step backwards up the slope, or put the rod over their shoulder and clamber into the scrub, then run back to the water's edge, reeling in line all the while. This manœuvre is repeated until the fish rolls on its side within reach of the gaff. Mindful of the strain which it threw on my stomach the first day I tried it; I now sit tight, but another quarter of an hour goes by, thanks to the uselessness of my thumb, before I get control of the wayward runaway and bring it to Underhill's feet, so limp that it is not even necessary to spoil it with the gaff. It is dragged carefully ashore by the wire snell, and so as not to bruise both sides with the cutting sand, and is a beautiful deep fish well over six feet in length. Its exact length proved to be six feet four inches, and its weight 140 lbs., a trophy for my club in town, where to this day it reposes, inspiring goodness knows how many 
jaded townsmen to turn their back on Epsom and Ascot and fare forth to bring back a better from the blue treasure-stores of the Gulf. Judging from the many inquiries that have reached me from those who have stood before its dead effigy, I regard it as an enemy of its race.

The Pass presents a merry spectacle this sunny afternoon. The Useppa contingent is out in its full strength, and there are two more boats from the houseboat and two others from Mr Van Vleck's yacht Novia, so that eleven skiffs, all told, are fishing in that narrow channel, and never fewer than two of them are either dragging fish to the beach or returning to the fray from a landing-place where a shining trophy marks their latest prize. In one boat sits a lady, who jumps her tarpon with the best, yet loses each through the unskilful rowing of the skipper of her husband's yacht, who is acting as guide for the occasion. This is hard, for the sex has achieved many notable successes in other seasons. Mrs Turner and her sister caught in one season more than half as many tarpon as all the men of the party put together.

Again I am into what seems a monster, though we have only a glimpse of him at his one jump, after which he settles down to a steady run that proceeds without check for five or ten minutes. It seems too much luck to catch two "dandies" in one afternoon, but the fight that he is making convinces me that here is another big fish. The collapse comes suddenly, and I get the fish alongside the boat, only to realise that it is a fingerling of no more than thirty or forty pounds. The explana- 
tion of its apparent strength is that the fish is not hooked, not even foul-hooked, but the snell has made a running noose around the tail, the hook being fast in a link of the chain. The result is that the fish has been able to fight with its strength unimpaired, and I am at a loss indeed to understand its sudden collapse.

The bait is not touched and is soon down again, and next moment I strike hard at a nibble, but, after a momentary hitch, it comes away, and on the hook I find impaled a beautifully shaped little tarpon, scale no more than an inch across. This, I find, is so rare an experience that only one or two similar cases are recalled by the veteran of the party. To him all eyes are now drawn by a shout of friendly derision-I never realised how friendly derision could be until I had fished at Boca Grande-as he is seen playing something heavy to the beach. Although he already knows more about tarpon-fishing than the rest of us are ever likely to learn, his luck has not hitherto been of the best, and he has won a mournful reputation as a gatherer of jewfish, grouper and other rubbish of the same calibre. This afternoon he has hooked still stranger game, for he presently lands on the beach an immense loggerhead turtle, foul-hooked in one of the flippers. Caramba! but its fat will simmer slowly this night in a savoury mess for the supper of Manuel, his Spanish guide, and of such cronies as are bidden to the orgy.

"Mind your head, sir!" and a tarpon not far short of 100 lbs. falls back in the water within half a dozen yards of the Colonel's boat.

"Mind your fish, sir!" is the retort, as the 
fisherman sadly reels in his line to get a new bait.

I get a couple more that afternoon, one of about $80 \mathrm{lbs}$., the other between $60 \mathrm{lbs}$. and $70 \mathrm{lbs}$., and then, just as it is getting dusk, and one or two of the fleet are paddling back to the launch in readiness for the return journey, I lose a really good fish-as big, so far as can be seen in the failing light, as my best on the beach yonder-in a very strange manner. Twice it jumps, but it is evidently not able to throw out the hook. Then, of a sudden, and with no particular strain on the rod, the tension relaxes, and the line comes back to me, minus sinker, minus snell, apparently cut through as if with scissors not very far from the rod. Underhill explains this as the work of a kingfish. The tarpon has the trick of many fish, blowing the bait many feet up the line when hooked. Sometimes it flings away the bait as it flings away the sinker, but it often sends it up the line. This does not always matter, but on this occasion a kingfish must have been cruising round the boat, must have dashed at the bait, and its sharp teeth must have severed the line in a flash. For such a rencontre there is no remedy. Indeed, this is the one way of losing a tarpon (I shall enumerate others on a later page), in which the angler is in no way to blame and can do nothing to save his fish.

Consoled in a measure by this reflection, I too rejoin the homeward fleet. No fewer than twenty tarpon have bitten the sand this day, out of which total the Useppa seven claim fifteen. Great is the rejoicing as we run back in the darkness, giving, as is our custom, a blow of the whistle for each fish 


\section{I36 SUNSHINE AND SPORT IN}

as we draw up to the pier. In my own mind great also is the regret that fifteen such magnificent fish should be slain to no purpose. Hunting and fishing for the pot are justifiable in the eyes of all but the anæmic zealots who live on nut foods, but this purposeless, wasteful shambles on Useppa Pier is sickening, and those who organise the annual tarpon carnival would deserve better of their generation if they could make some kind of arrangement for weighing each fish in something like a net bag, not impaled on the hook of a steelyard. The apparatus should be kept down at the Pass, so that it would be possible to turn each fish adrift after weighing it. It is alleged that fish so restored to the water would at once fall victims to sharks, but I disbelieve this absolutely. Seeing that, as will presently be shown, a tarpon can often elude a shark even on the hook, it is by no means likely that the shark would succeed in catching it without such handicap.

This is my last day, for on the morrow I must be on my homeward journey by way of the calm Caribbean.

On the whole, I am well satisfied with the results of my trip. Seventeen tarpon in eleven days of fishing are, says the veteran, a very good record. Not one of my fish is really big, as tarpon go, yet it is good luck to have caught the best of them on my last afternoon, and with a borrowed tip after the sharks had broken my own.

The following is the Useppa record for the summer of 1906. The season lasted, as will be seen, from 2 Ist April to I9th May, but one or two of the party were fishing at Useppa from 
the first week of April without getting a single strike.

\section{USEPPA RECORD FOR 1906 \\ (exclusive of the last three days)}

\begin{tabular}{|c|c|c|c|c|c|}
\hline \multirow{2}{*}{\multicolumn{2}{|c|}{ April 21 }} & & & \\
\hline & & G. H. Ramsbottom, & & & Alfred Whitehead \\
\hline " & 22 & E. Vom Hofe, & 123 & $"$ & Manuel Alinas \\
\hline " & 25 & G. H. Ramsbottom, & $3^{8}$ & $"$ & Alfred Whitehead \\
\hline$"$ & 25 & L. W. Kingsley, & × 35 & " & Sam Woodring \\
\hline " & 26 & Gardiner G. Hammond, & 62 & " & Ramong Bylasky \\
\hline$"$ & 27 & W. H. Chase, & 68 & ", & Julius Whitehead \\
\hline ", & $\begin{array}{l}28 \\
28\end{array}$ & G. D. 'E. Muntz. & 50 & " & re \\
\hline & 30 & F. G. Aflalo, & $\begin{array}{r}127 \\
85\end{array}$ & $"$ & George Underhill \\
\hline Iay & $\mathrm{I}$ & G. H. Ramsbottom, & $6 r$ & , & Alfred Whitehead \\
\hline ני & 3 & " & 98 & $"$ & $"$ \\
\hline$"$ & 3 & " & 48 & " & $"$ \\
\hline$"$ & 3 & F G Aflalo & $\begin{array}{r}76 \\
8\end{array}$ & , & " \\
\hline$"$ & $\begin{array}{l}3 \\
3\end{array}$ & $\begin{array}{l}\text { F. G. Analo, } \\
\text {, }\end{array}$ & $\begin{array}{l}108 \\
\text { ro8 }\end{array}$ & $"$ & \\
\hline " & 3 & E. Vom Hofe, & 165 & " & Manuel Alinas \\
\hline " & 4 & G. H. Ramisbottom, & 48 & " & Alfred Whit \\
\hline " & 4 & $"$ & I 28 & $"$ & " \\
\hline$"$ & 4 & " & 78 & $"$ & " \\
\hline " & 4 & " & 63 & $"$ & $"$ \\
\hline$"$ & 4 & F. G. Aflalo, & $\begin{array}{l}50 \\
86\end{array}$ & $"$. & George "Underhill \\
\hline " & 4 & , & 68 & " & , \\
\hline " & 4 & & 47 & " & \\
\hline$"$ & 4 & Col. D. M. Lumsden, & 65 & " & Charles Pratt \\
\hline$"$ & 5 & " & 92 & $"$ & " \\
\hline$"$ & $\begin{array}{l}5 \\
5\end{array}$ & G. H. Ramsbottom, & $\begin{array}{r}90 \\
160\end{array}$ & $"$ & Alfred Whitehead \\
\hline " & 5 & & $9^{\mathrm{I}}$ & " & \\
\hline " & 5 & H. B. Tate, & 84 & " & Charles Leatham \\
\hline " & 5 & G"Aflal & 72 & " & \\
\hline$"$ & $\begin{array}{l}5 \\
5\end{array}$ & & $\begin{array}{l}40 \\
18\end{array}$ & " & George Underhill \\
\hline " & 6 & E. Vom Hofe, & 68 & $\begin{array}{l}" \\
"\end{array}$ & Manuel Alinas' \\
\hline " & 7 & " & 155 & " & " $=2$ \\
\hline$"$ & 7 & G. H. Ramsbottom. & 78 & " & Alfred" Whitehead \\
\hline , & 7 & & 72 & " & \\
\hline " & 7 & & $7 \mathrm{x}$ & ", & es Lea \\
\hline$"$ & 7 & F. G & $3^{8}$ & " & ge Underhill \\
\hline & 7 & & 64 & & les Pratt \\
\hline
\end{tabular}


May 7 Col. D. M. Lumsden " 9 F. G. Aflalo,

" 9 A. K. Mellor,

" 9 G. H. Ramsbottom,

" 9

" 9

" 9

"

$"$

"1"

"13

"13

"1 13

" 13

" 15

" 15

"15

" 15

" 15

"15

" 15

"16

" 16

" 16

, 16

" 16

") 16

" 16

". 16

" 16

" 16

" 16

" 16

" 16

" 16

". 16

"16

" 16

" 17

" 17

" 17

"I7

" I7

" 17

"17

"

" 17

" 17
Col. D. M". Lumsden,

E. Vom Hofe,

G. D. " E. Muntz,

Col. D. M". Lumsden,

H. B. Tate,

F. G. Aflalo,

"

")

")

"

G. D. E. Muntz,

G. H. Ramsbottom,

"

Col. D. M". Lumsden,

H. B. Tate,

E. Vom Hofe,

C. F. Naething,

G. H. Ramsbottom,

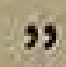

,

"

Col. D. M". Lumsden,

H. B. Tate,

G. D." E. Muntz,
G. H. R̈amsbottom,

"
54 lbs. Chide.

Charles Prat

I 10 " George Underhill

120 W. M'Guire

I45 " Alfred Whitehead

98 "

82 " ,

62 ,

70 "

$140 "$

96 "

85 "

84 "

$105 "$

70 "

77 "

I10 "

$74 "$

I 77

70 "

60 ",

$140 "$

80 ,"

80 ,

$67 "$

80 "

88 ,

123 ",

I10 "

62 "

I45,

II 7 "

ro8,

98 "

65 "

65 "

65 ,

95 ",

$100 "$

99 "

70

60 ,

50 "

rog ",

72 ",

I 35 "

I23 ",

90 ",
Charles Pratt

Manuel Alinas

Bethel"

Alfred Whitehead

Charles Pratt

Charles Leatham

George Underhill

Bethel

Alfred Whitehead

Charles Pratt

Charles Leatham

Manuel Alinas

"

Alfred Whitehead

")

",

"

Charles" Pratt

Charles Leatham

Bethel 
the average, if I remember right, though I have not the figures, and in 1905 there was no season, the inn being closed. This, and perhaps insufficient advertisement of the resumption of business, was probably the reason of the few visitors last season.

Having now endeavoured to give some idea of the mode of procedure in Pass fishing by describing particular episodes, I must now turn to the brief but necessary consideration of some general principles, both practice and ethics, which will perhaps be more intelligible after what has gone before.

The reader's attention has been drawn to the great, perhaps excessive, strength of the tackle. Of this the rod is the most uncompromising element. We used to chaff the veteran with the suggestion that he made his tarpon-rods out of condemned billiard cues, a theory which he took with his usual good humour, and which will be better appreciated by those who have handled the typical American billiard cue. Exaggeration is a part of caricature, and, as a matter of fact, the tarpon-rod is far more elastic than even the most springy English cue, for I have seen one bend like a reed in a gale. Yet, for all that such rigidity may, as alleged, be necessary to strike the hook well home, I should dearly like a moderate-sized tarpon, one of, say, 50 or 60 lbs., on a Hardy split cane salmon-rod. It may be that in the case of slight nibbles, which perhaps predominate, so violent a response is needed that the salmon-rod would not stand the test, but those fish that rush 
the bait and to all intents and purposes hook themselves might surely be played on salmon-tackle, and what sport they would give, to be sure! In somewhat shallower water in Jamaica they kill tarpon of the weight suggested on salmon-tackle, and I do not see why a little extra depth should put it out of action. At any rate, one killed in this fashion, taking perhaps a minute for every pound of its weight, would be infinitely more enjoyable than a score butchered in the orthodox way. That, I imagine, needs no argument. There are even occasional small tarpon, which would without any doubt whatever give admirable sport on the lighter gear. The worst of it is that, in the Pass at any rate, no one knows where to find them in preference to those of heavier build, for they all feed together and on the same grounds. Thus, one moonlight evening I caught a beautifullyshaped little tarpon of only 18 lbs., as game a little fish as I would wish to have on my bass-rod at home. I have since regretted not having had it mounted, as it exhibited all the characters of the species to perfection and on a miniature scale far more convenient for the walls of a modest residence than the giants usually set apart for the purpose. Within a few minutes, and at a distance of no more than a few yards from where I had hooked the baby, Ramsbottom was fast in an immense fish of 160 lbs., which was, as a matter of fact, foul-hooked, and therefore endowed with fighting efficiency far above its weight had it been hooked in the mouth. The fish got his boat under tow, and he quickly vanished out of sight of the rest of us, as the horizon of moonlight on the water is not a very 
wide one. It smashed his rod, and was saved only by his own skill and the great pluck of his coloured guide, who, risking a capsize, clambered out over the stern and handlined it to the gaff in deep water. Some days, on the other hand, there is a very remarkable uniformity among the fish, as if those of a size went in shoals. One evening I got two to the beach in rapid succession, each of them measuring exactly 5 feet 9 inches and weighing exactly $108 \mathrm{lbs}$. Another day I caught two, one after the other, exactly $80 \mathrm{lbs}$. apiece.

Although in the natural state they are probably, like the majority of herrings, surface-feeders, they take the bait at considerable depths, and occasionally one follows it up to the boat. One of about $80 \mathrm{lbs}$. followed mine up to the top of the water in this fashion, seized it with a jerk that nearly pulled me over the side and, without even jumping, threw out the hook, which, not expecting the fish, I had not struck home. This is an exceptional experience, but the same thing happened, once each, to $\mathrm{Mr}$ Vom Hofe and $\mathrm{Mr}$ Ramsbottom.

The contention that luck and brute strength count for more in tarpon-fishing than previous experience and skill may perhaps be thought to call for illustration. As regards the part played by luck, I cannot do better than contrast $\mathrm{Mr}$ Vom Hofe's ten fish with my seventeen. I knew nothing whatever of tarpon-fishing; he knew everything that there is to know, and his experience of the sport dates from its first year. There is just one feature of his ten fish, which may possibly indicate the result of special knowledge, but even 
this is open to doubt. It will be noticed that five of them exceeded roo lbs., one being the best fish of the year. Now, Mr Vom Hofe may perhaps have reason to think that big tarpon feed head downwards, routing among the shingle and coral for their food. That such is the case is indicated indeed by the frequency with which the heavier fish are hooked in the nostrils. Therefore by fishing deeper than the rest of us, he may perhaps have caught the greater proportion of big fish. At the same time, it is not to be denied that fishing deep carries the penalty of hooking other fish, of which he caught considerably more than his share.

Luck occasionally takes strange shapes. A friend of mine, also visiting Boca Grande for the first time in 1906, caught on his first (and only) day in the Pass a handsome fish of $120 \mathrm{lbs}$. Then followed several days of stormy weather, during which the Pass was deserted, Indeed, before we got out again, and while we were putting in the time catching small fish near Useppa, he managed, while wading in the shallows to get fiddler-crabs for bait, to cut the instep of his foot so severely on a broken oyster-shell as narrowly to escape lockjaw. That was the end of his fishing, for he had to return North for surgical aid, but his ill-luck only made it the more lucky that he should have had that one success. An analogous case was remembered by those who had been at Useppa before, that of a sportsman from England catching a fish of 140 lbs. on his first day and finding, on his return to the inn, a cablegram demanding his immediate return home on account of illness.

Luck, as has already been said, is negative as 


\section{SUNSHINE AND SPORT IN}

well as positive, and bad luck may mean not only getting no strikes from tarpon, but getting too many from less desirable fish. My own experience with a shark which took possession of me and my boat for over two hours, wasting precious time while the rest were catching tarpon, is a case in point.

The need of brute strength is perhaps less easily demonstrated, particularly when it is remembered how much of the brunt is borne by the tackle and what immense fish have been safely brought to the beach by ladies and lads. As a matter of fact, many ladies have considerable muscular strength, and one of the most successful in the Pass is endowed with quite exceptional physique. Even in 1906, the member of the party who caught by far the greatest number of fish, often enough by getting each to the beach in half the time that anyone else would have taken, was also without a doubt the most powerfully built. I do not, in urging the importance of strength-in view of the fact that ladies have been so successful, I ask leave to withdraw the offensive epithet used above-I do not lose sight of the fact that fishermen of slight physique can and do kill tarpon. All that is suggested is that a powerful man will kill his tarpon in far less time. Need I go further than quote, to those who know his athletic build, the case of Lord Desborough, who, I suppose, killed the record number of tarpon in three weeks - a hundred fish, if I remember right. It was, I have been told by an eye-witness, simply a question of his winding in the largest tarpon as if it had been a dace swimming past his own lawn at Taplow.

Conversely I have ventured to express the 
opinion that skill goes for very little. This is not an agreeable attitude to take, as it may easily give offence to hypersensitive sportsmen who have prided themselves not a little on their success with tarpon. Nevertheless, I can honestly take no other view of the case. I desire, however, to make exception in favour of three difficulties that only skill and judgment can retrieve: pursuit by a shark, a broken tip, or a large fish foul-hooked. As for the ordinary correct manner of handling a jumping fish, or one that dashes towards the boat with the object of snapping the slack line by a sudden change of direction, it is, or should be, known to everyone who knows anything of fishing at all, and may therefore be passed over. The remedy is in either case a mere matter of common sense, though lengthy discussion on the subject of whether or not to lower the rod-top when a fish jumps are occasionally welcomed by angling editors during the dog days. Exceptional skill, of a kind not perhaps called for in any familiar kind of fishing at home, is, I think, restricted to the three cases allowed for. Only for the first, pursuit by a shark, can any suggestion be offered, and that only to the effect that when a shark is seen chasing a hooked tarpon, the latter should be given every chance of eluding capture. Where the fisherman is very apt to err is in trying to reel in his fish faster than the shark can catch it. This is fatal, for the natural and uncontrollable instinct of a hooked fish is to pull in the opposite direction if hauled, and as soon as the fisherman applies the closure, the bewildered fish, finding itself between the devil and the deep sea, is certain to let itself be 


\section{I46 SUNSHINE AND SPOR'T IN}

taken in the jaws that gape in its wake. The proper course is to let the fish pull line off the reel, giving the tarpon scope, yet, so far as possible, keeping a tight strain, and it is wonderful how nimbly, even with the handicap of a hook in its mouth, it is able to turn and twist and baffle the shark. Patience is the only hope in such a case, and by infinite manœuvring it is sometimes possible to coax both of them so close to the beach that at length the shark, which has no use for guides with gaffs, fears to follow and ignominiously turns tail.

To save a large fish that has broken the tip, or one that is foul-hooked and consequently able to exert its full strength as no properly hooked fish could ever do, presents difficulties that only the inspiration of the moment can avert. There is no rule for either dilemma. As already related, these problems faced one member of the party simultaneously, with the further handicap of the indifferent light of the moon to work by, and he and his guide won the game. He attributed the result almost wholly to the sang froid of the guide, but his own share must have been considerable.

As a corollary of my contention that skill plays only a small part in the average encounter with tarpon, I may perhaps be allowed to quote from an old number of that excellent American journal, Forest and Stream, several ways in which, according to $\mathrm{Mr}$ J. A. L. Waddell, an authority on the sport, a tarpon can be lost. These are as follow :-

I. By failure of the hook to penetrate a soft place.

2. By the cutting of a hole in the mouth, from which the hook drops out when the line is slackened. 
3. By breaking or corkscrewing the hook.

4. By breaking the line, owing to-

a. Its deterioration.

b. Fouling by overrunning of the reel.

c. Tangling of something by the reel handle.

d. Too severe application of brake or reel handle.

5. By breaking the snell.

6. By breaking the rod, generally in the tip, but sometimes in the butt.

7. By carelessness of the boatman in gaffing.

8. By attack of a shark.

To this list of the causes of failure, which is categorical enough to have pleased the late $\mathrm{Mr}$ Gladstone, two addenda may be suggested, both of them sub-sections of No. 4. The first is that of a kingfish cutting the line by dashing at the bait blown up it by the tarpon; the second is the possibility of an inferior line insufficiently tested before leaving the works. I have known one absolutely new line utterly fail.

It will be seen from a glance at the foregoing analysis that the tackle is quite as much to blame (in $1,3,5$ and 6) as the fisherman, and indeed only in two cases $(2$ and 4$)$ is the angler wholly responsible for disaster. No. 2 occurs mostly when the fish is reeled close to the beach. On sunny days, when the white sand shows conspicuous, the tarpon, seeing danger in the gleam of sand, is apt to take alarm and sheer wildly to right and left, thus making a longer wound, from which the hook is liable to fall out. The only remedy is to get the fish to the gaff as soon as possible, and here again muscle tells.

Nos. 3 and 5 would be wholly the fault of the tackle, for not Hercules himself, I imagine, could 
break either hook or snell if both were as they should be.

No. 6 may be, generally is, perhaps, the fault of the fisherman, though some of the sharks are of immense weight and strength and apt to smash the rod by a sudden lurch, against which, without risking the equally fatal trouble of the reel overrunning, it is very difficult to guard. It is the tip which goes as a rule, but I saw one rod go in the butt just as the fisherman got the tarpon, a fish of I 20 lbs., to the beach. Fortunately, the fish was exhausted, else its loss would have been certain.

No. 4a. The line should, of course, be carefully dried after each day's fishing. This is, or should be, an unfailing rule with all lines used in salt water. To let them dry gradually on the barrel of the reel causes them to rot very rapidly. This is part of the guide's work, and he should also test the line every evening to see if it needs changing ends or replacing with a new one.

$4^{b}$ and $c$. I cannot see how either could happen with one of Vom Hofe's newest improved reels.

$4 d$. This is simply a case of bad fishing, particularly of erroneous judgment of just how much strain the line can be expected to stand.

Nos. 7 and 8 have been dealt with earlier.

Reference has more than once been made to the startling experience of the fisherman when a tarpon hooked by someone else jumps close to his boat. Though this may seem to add the requisite spice of danger to this alluring sport, accidents are as a matter of fact very rare. Fishing once on the east coast of Florida, Mr Vom Hofe did, it is true, drop 
a tarpon so close to a friend's boat that it fell on the oar and smashed it off short, but no other damage was done. The mishap which befell $\mathrm{Mr}$ Otis Mygatt, who was badly injured by a porpoise falling on him one night, is also among the annals of Pass fishing. The only case of actual fatality that has come to my notice was when a boat was found drifting in the bay off Galveston containing a dead tarpon overlying a dead fisherman, a horrible discovery that could have but one explanation. The unfortunate victim must have been fishing without employing the services of a guide, a fatal economy, for the latter would, with a stroke of the paddle, have dodged the fish in its fall.

\section{Still-Fishing.}

OF the other methods by which tarpon are commonly taken, one only need be described in detail. In the West Indies, as has been stated, the fish is taken on the fly, prawn and other baits. At Captiva Pass, where the water is shallower, and where, at any rate in 1906, sharks were too numerous to make fishing either comfortable or profitable, it is found best to troll near the surface without leads, a sporting method, but one entailing a great proportion of lost fish.

The other method with a wide vogue, particularly in estuaries and on the shallow mud-flats up the creeks and rivers, where indeed no other style is practicable, is that known to Americans as "stillfishing," and to ourselves by the more tell-tale name of "gorge-fishing." It is in no sense a sportsmanlike method, but it catches fish. It is the mode 
adopted by deep-sea fishermen, who leave long lines with hundreds of hooks out all night, and take them up again next morning, finding numbers of fish tethered to the snoods, and with the hooks deep down in their stomachs. It is the style of fishing adopted in many parts for pike. It is, once more, eminently deadly, but also the lowest form of sport. Still, those who are so placed that no better kind of fishing is possible cannot be blamed for catching a tarpon that way rather than not at all. Having no partiality for gorge-fishing in any shape or form, and being conveniently situated for the more satisfactory method, I did not once try it, but some idea of the method may be gathered from an interesting letter received from a sportsman at Fort Myers, where, without forming a high opinion of the way in which he was compelled to catch his fish, did as Rome did, and evidently derived some amusement from the experience.

"HOTEL BRADFoRD,

"Fort Myers, ist May.

". .. Mr $\mathrm{Mr}$, whom I have met here, told me that he met you coming down on the train from Jacksonville. He said that you were going down to Useppa Island to fish for tarpon in Boca Grande Pass. . . . I am writing to tell you of the sport we are having here with the tarpon, because, unless you are better informed at Useppa of the sport we are having at Fort Myers than vice versâ, you will have very little idea of it. The only reliable information that we have received from Useppa was from three guides, who returned here yesterday, and from their account, sport seems to have been really poor there. Here, for the last week, we have been having great sport. I myself caught my first fish on Sunday week, and in eight days' fishing since then have caught nine fish, losing 


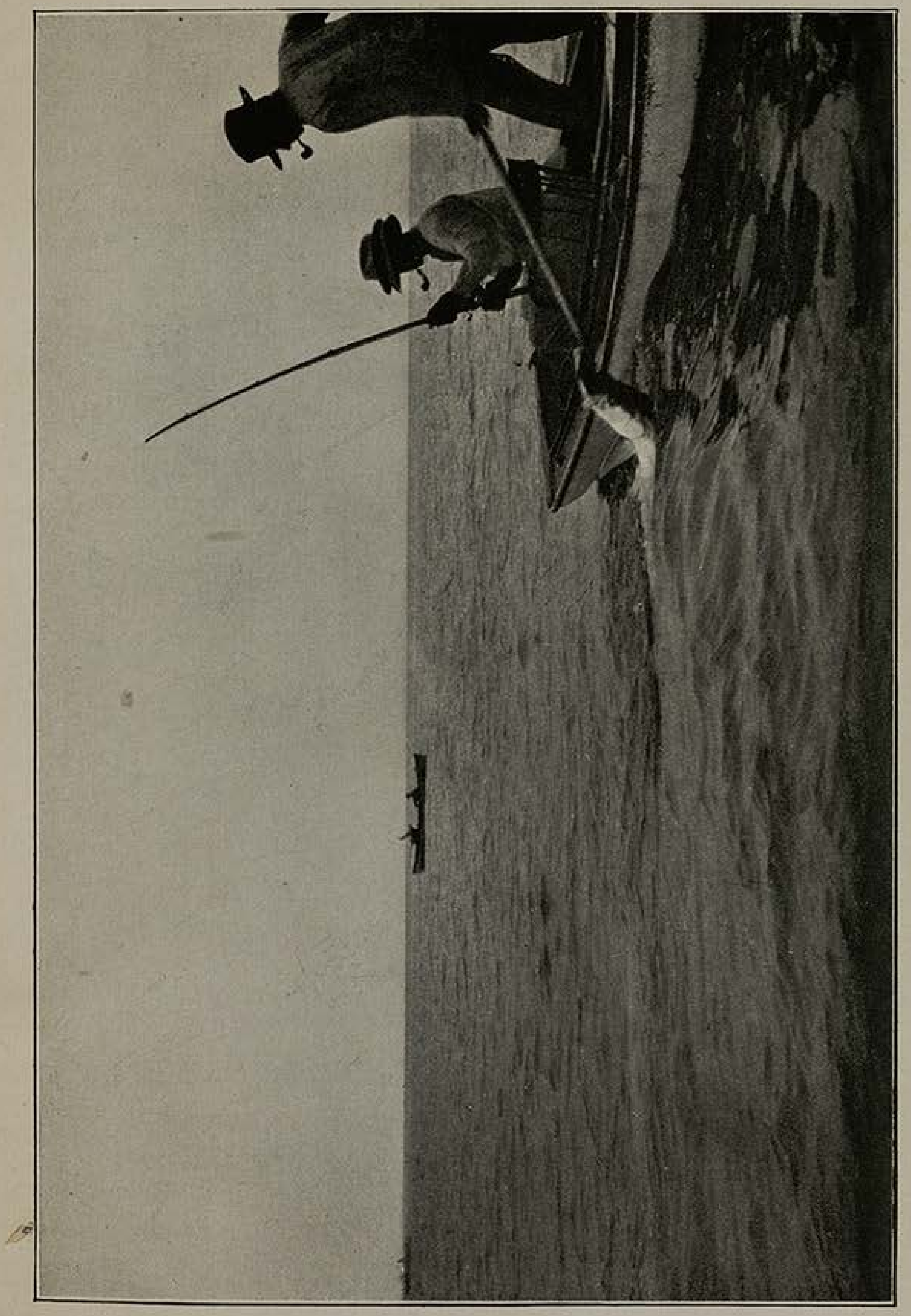

定

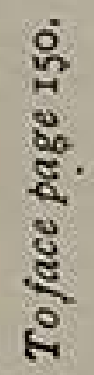




\section{FLORIDA AND THE WEST INDIES I5I}

six others that I consider were properly hooked. The river is full of tarpon, and, with any luck, you are bound to catch them here. One day I had eleven strikes, but only got two fish out of them. I caught three in one day, and to-day a man called Powers caught four, ten tarpon having been taken to-day altogether.

The mode of angling for tarpon here may not appeal to you. It certainly does not appeal to me in the very least. Indeed, I loathe it, having been accustomed to fish for salmon and trout, and one feels no better than a Sunday angler on the Thames, sitting all day long in a boat instead of on the bank, holding a line in one's hand and waiting for a tarpon to take the bait. From all I can hear, however, when once hooked, the tarpon here will give you far better sport than in the Pass. I have talked to several people who have fished in both places, and they are unanimous in the opinion that fish hooked in the river give one far more sport. Here, you see, when you have hooked your fish, you play him from your boat till you have tired him enough to bring him up to the gaff. In this way you get the advantage of seeing all his amazing leaps and dashes, which, from all accounts, you must miss at the Pass. . . . You get the tarpon really in his element as from your boat you have to fight him till he comes in belly upwards to the gaff. . . . If nothing is doing down at Useppa, I should certainly recommend you to try the river here, as it is just in full swing now, and I hear that the Passes are always better later. I know perfectly well that you will hate the mode of angling here, but when your fish is hooked, he gives you the grandest sport, and you forget the mean way in which you caught him."

In the course of his interesting comparison between the two methods, gorge-fishing and trolling, my correspondent raises more than one debatable point on which, if I had actually tried the method, I might have liked to join issue. In the absence of first-hand knowledge of the river at Fort Myers, I 
will content myself with expressing surprise that any fish hooked deep down in its inside should be expected to give better sport than one hooked just in the edge of the mouth. At any rate, I can recall no analogy in support of the contention, and I fancy that if my correspondent had tried the Pass as well, he would have modified an opinion based on hearsay.

So splendid a fish as the tarpon should be given the best chance in the fight. For this reason, I have criticised somewhat unsparingly the great strength of the tackle employed in Pass fishing, which seems to me, from the point of view of sport, excessively powerful. To let the fish gorge the bait and thus hamper it in its magnificent evolutions by a hook and stiff wire embedded in its vitals, appears to me, with all deference to the gentleman who, though disliking the method, claims that it gives good sport, nothing short of heinous. I would as soon set trimmers for trout. 


\section{VII}

OTHER FISHING

That the tarpon is the end and aim of our pilgrimage to the Gulf coast goes without saying, but, while consecrating our best efforts to cultivating his acquaintance, we need not overlook the presence of a number of other interesting fish on the same grounds, all of which would be deemed excellent game for the rod if there were no tarpon to monopolise our admiration.

Of those encountered incidentally in the Pass, and there, I regret to say, regarded in the light of vermin, the chief are the

\section{Jewfish (Promicrops itaiara) \\ Black Grouper (Garrupa nigrita) \\ Red Grouper (Epinephelus morio) \\ Kingfish (Scomberomorus cavalla) \\ Channel Bass (Scianops ocellata) \\ Cobia (Rachycentron canadum)}

and a variety of sharks and rays, some of the latter leaping high in the air to throw off the irritating remoras that cling to their skin and falling back in the water with a resounding splash that startles newcomers unused to such apparitions. If one of these great rays were to fall on the boat, there would be an end of its occupants, but no doubt the fish sees the boat overhead and takes good care to leap wide of it, else accidents of the kind must have 


\section{54

occurred ere now, and, so far as I am aware, none has ever been recorded.

The jewfish, groupers and channel bass are taken deep down, generally when the bait is allowed to sink lower than forty-five or fifty feet. The kingfish and cobia seize the bait, as has been said, close to the surface, and a kingfish of twenty pounds or so gives such dashing sport that it would be a delightful fish on a salmon-rod. On the crane used to haul tarpon its struggles are insignificant.

In the shallower water round Useppa we find a number of small fish, many of which give the best of sport on an old trout-rod and light tackle to match. Even if a north-easter did not occasionally impose a close time of several days' duration on the Pass, tarpon-fishing might, but for an occasional interlude with smaller game, pall like partridges. The shore waters of Florida are so abundantly stocked with fishes of a dozen kinds that every little bay and inlet will keep the angler's float bobbing by the hour. This profusion of fish is doubtless due to the beneficent influence of a Gulf Stream not yet chilled by its passage across the colder ocean, and some of the riches of those waters must also, no doubt, be attributed to under-fishing, a rare virtue in these times. At any rate, the fisherman of catholic tastes need never know an idle hour. Even on the beaches of the Pass itself, garfish, silver mullet and even small sawfish, sport right up to the water's edge, and a score of fish will dart between the feet of anyone wading along the shore, while a wave heavier than the rest will sometimes throw a whole shoal of mullet up the sandy slope, from which they quickly struggle back to safety. 
On rough days, then, when there is too much wind for fishing in the Pass, small fishing can be indulged in close to the island, either from boats moored a little way out, or from the pier opposite the residence of the proprietor, Mr Roach.

The species that may be caught in this fashion are the

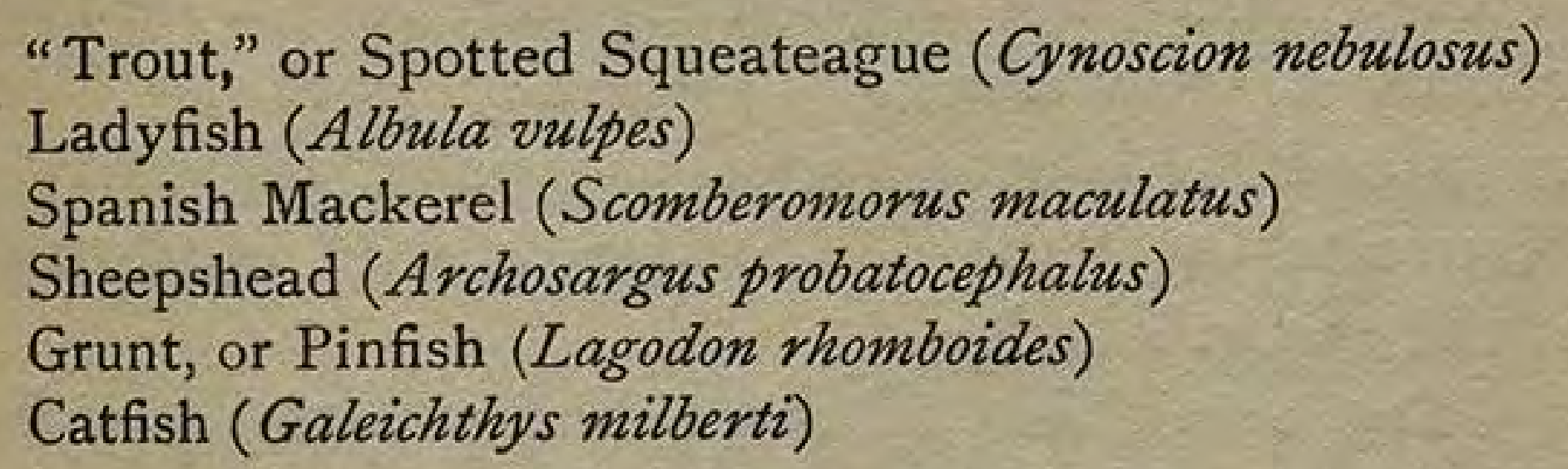

Of these, the so-called "trout," or "sea-trout," is perhaps the most game. The little silvery ladyfish also leaps out of water much like a tarpon, though never, I think, weighing more than three or four pounds. The largest that I took weighed no more than one. It is also called "Weakfish."

An old trout-rod and float-tackle will give the best sport with this miscellany. The boat may be either anchored wherever the fish are found on the feed, or may be allowed to drift slowly over a wider area, picking up whatever it happens upon. The best bait for most of these fish is the "minnow," or "shiner," of which mention was made on an earlier page. It may be hooked through the tail and fished a little way from the bottom unless catfish are too numerous, when it should be raised out of their reach.

The variety of boat-fishing at Useppa is like that of the Pass, only everything is in miniature. In four casts, I have hooked a "trout," a Spanish 
mackerel, a "lady" and a "cat," the largest being the mackerel, which weighed over $3 \mathrm{lbs}$. and fought like the Cid. Examples of twice or even three times that weight are caught there, so I understood from Underhill, and in that case it would probably be good-bye to the light tackle. The catfish is the catfish all the world over. It is neither pretty nor a good fighter, and a derisive chorus of "miaowing" generally goes up from neighbouring boats as soon as one of the party is seen catching "cats." Sympathy with misfortune is the angler's badge.

The small fish of these backwaters have one advantage over those in the Pass. They are for the most part good to eat, though the "ladies" are very bony and the "trout" are at this season full of worms.

The Spanish mackerel, if a little rich, was admirable, and the sheepshead-a black fish with silver bands, not unlike the sargo of Madeira, if indeed they be not identical-is a bonne bouche much appreciated as an acquisition to our somewhat meagre island larder. The proper bait for these sheepshead is the fiddler-crab (Gelasimus pugnax), and the best spot thereabouts is at the end of the pier opposite the Chateau Roach on the halfflood. A float should be used, and the bait, hooked through the tail, allowed to drift just clear of the bottom. The sheepshead, which I caught up to $4 \mathrm{lbs}$., shows great fight, and it needs some tact and diplomacy (of the new sort) to keep it away from the piles, round which it would foul the gut tackle in a twinkling.

When fishing here for sheepshead, the angler is 


\section{FLORIDA AND THE WEST INDIES I 57}

certain to catch a number of grunts, so called from their gurgling sound when removed from the water, a feeble edition of the conger's "bark." The fiddler-crabs may be gathered by the pint alongshore at low tide, but great care should, as may have been inferred from an episode related in these pages, be taken not to tread on broken oyster-shells. In every little bay, high and dry among the oyster-studded mangroves, these pugnacious little crabs may be seen scuttling in and out of their burrows. Florida is a land of burrowers. There are burrowing mammals, burrowing reptiles and burrowing crustaceans. From the look of some of the "crackers" who drifted past Useppa pier on broken-down craft of obsolete and fearful model, I should not wonder indeed if there are also burrowing men and women. 


\section{VIII}

\section{AN ALLIGATOR HUNT}

ONE of the obiter facta of a holiday in Florida was, so a friend at home assured me, a hunt for alligators, for which purpose he advised me to take one of my rifles, preferably a sporting Winchester, in my kit. I did so. The rifle was all but left on board the Cunarder at New York (I devoutly wish that it had been), it involved me in a tedious business with the Customs at Havana, and, without firing a single shot throughout my trip, its ultimate fate was to figure in a fancy-dress ball on board the Tagus coming home. Had it been in my boat in the Pass on the day of the big shark, the whole of its magazine might perhaps have been emptied to some purpose into that shagreen hide, but at that moment it reposed unloaded in a corner of my room at Useppa.

One windy day, with the Pass quarantined for fishing, we got up an impromptu alligator hunt on the island of La Costa. The moving spirits in a drama that proved to be Hamlet without the Prince were "Johnny Jack," the Useppa taxidermist, and my guide, Underhill, who has, on his native island of Sanabel, acquired a nose for an alligator that does him credit. Underhill declared that he knew of an immense 'gator on La Costa, not far from a landing that we could easily reach in Jack's launch, the Naturalist; so, late one after- 
noon, with darkness not far off, we mustered on the pier, as sorry-looking a crowd of filibusters as could well be found outside the pages of $\mathrm{Mr}$ Jack London or Mr Conrad, both of whom seem to have made strange acquaintances on their walk down life's highway. The general scheme of clothing may be glozed over. Our raiment was cool, but immodest, and we wore indeed little more clothing than the reptiles we had come so far to unearth. The footwear alone showed individuality: two of the party, fearing rattlesnakes, wore top-boots ; the rest, indifferent to such risks, went in tennis shoes, or even stocking-foot, and one came forth in a splendid pair of sealskin slippers, a trophy from an Irish lough, picturesque enough in the smokingroom, but in swampy ground a trifle inclined to stay behind.

The launch pushed her nose up on the landing, and one by one the party disembarked. Then Jack and Underhill assumed the leadership, one of them wielding an immense pole, the object of which will soon be appreciated, the other carrying a short-handled gaff to which was attached a coil of rope. I shouldered my rifle, vaguely imagining myself on a punitive expedition in the bush, and another had a revolver stuck in his belt like one of the Pirates of Penzance. On the whole, indeed, we made a very effective comic-opera combination, and if alligators are gifted with a sense of humour, some of them, peering from behind the dense screen of rank undergrowth, must have chortled happily.

Of path there was no more than that made by those in front hurling themselves against the 
chevaux de frise of saw-grass, three-edged blades of which wave in great tangles as high as the tallest man's eyes, with prickly-pear to detain keepsakes from the breeches, and stunted palmetto to trip the feet. The shortest ramble on those islands, the moment you leave the beach, is one continuous battle with the vegetation, which is, in fact, far more formidable than the animal life.

Hush! Underhill has struck a trail. With head lowered, like a Cherokee brave tracking his enemy, he pushes on, his eyes never off the ground, and from time to time halts to consult with his confederate. At accelerated pace these backwoodsmen press on through that miserable maze of vegetables mimicking barbed wire, and we unfortunates struggle torn and breathless in pursuit, not liking to call a respite, not daring to be left behind in the gathering gloom. If only Underhill had offered me at that moment five shillings for my rifle, which he had much admired, it would not now be mine! The final consultation lasted long enough for the stragglers to come up with the vanguard, and there, sure enough, was the spoor of evidently a large alligator, with other indications of where its tail and body had ploughed their lonely furrow over half a mile of oozy haunts, leading unmistakably to a large swamp, in the bank of which was a low hole. This looked to our unpractised eyes scarcely large enough to accommodate a well-fed eel, but Underhill declared that it was the front door of the 'gator's family mansion.

We had him safe, the experts agreed, unless there was another way out. Alligators, it appears, often leave a back way, like burglars, and the 
reptile at whose front door we now unmasked our batteries had, it soon transpired, not overlooked this essential condition of safety. The excitement was tense. Pole, gaff, rifle and revolver were requisitioned, and a large and powerful spade now made its appearance for the first time, having been carried by one who brought up the rear. Forgotten were the troubles with saw-grass and red bugs, the blisters and bumps even then rising on tender limbs. The pole was now thrust within the "cave." Underhill then informed us that the passage within turned off at right angles six or eight feet from the entrance. Often, he assured us, the naughty reptile is found close to daylight, when the gaff, with its coil of rope, does the rest in surprisingly short time, someone standing by with a stick to give the hermit his quietus as soon as his head emerges. On this occasion the end of our adventure at this particular cave was less dramatic. Someone of an inquiring turn of mind discovered another exit to this underworld, where, sure enough, the footmarks pointed away from home. Pole and gaff and other weapons were once more shouldered, and our indefatigable guides led the way to fresh pastures.

Another "cave" was reached within a few minutes, and here, they said, the conditions were very promising. Underhill knelt before the entrance in a gesture that suggested that he was vastly enjoying the effluvium of marsh-gas arising from the threshold with an odour that indicated less the residence of alligators than their burial-ground. Presently, however, we found that his object was business, not pleasure, for he began to utter a series 
of low and fearful grunts, placing his hand before his mouth, apparently to render his imitation of the alligator's trills yet more realistic. I was at once reminded of the way in which our Portuguese fishermen at Madeira used to whistle and sing for the murænas to come forth from their lairs in the rocks, and the analogy struck another member of the party, him of the sealskin slippers, who had fished with me in that distant isle. The only difference was that the murænas used to come forth in response to the invitation, while the alligators did not. Yet Underhill was quite sure someone was at home. The spade was accordingly got to work, since the pole failed, and we presently had the satisfaction of securing a magnificent alligator of about three feet. It was for this monster that I had brought a rifle that would, in other hands than mine, bring down an elephant at five hundred yards.

At a neighbouring health resort of the species, where the stench was almost overpowering to the untrained nose, Underhill secured two more, which actually did, to their own undoing, respond to his motherly cry. These ponderous reptiles, either of which would have gone at the time in my breastpocket, accompanied me viâ the West Indies to Devonshire, whence, after a month of incarceration in a small box in the drawing-room, they were eventually despatched to happier quarters in the Reptile House at the Zoo.

Such were the slender fruits of a hunt that promised such episodes as were to have consoled us for our banishment from the Pass. Alas! we returned to Useppa an even more disreputablelooking band of tatterdemalions than we had set 


\section{FLORIDA AND THE WEST INDIES 163}

out, the state of our clothing having been aggravated by the fact that the launch stuck thrice on the mud and we had to get out, waist-deep, and shove her off.

For him of the sealskin slippers, at any rate, the experience was too much, for he saw alligators the whole time. These infant creations of his heated brain were by tacit consent given the benefit of the doubt. True, someone on the return journey unfeelingly recalled an anecdote. It was that of the man, returning from a city dinner, who fancied that he saw a monkey in his hall.

"If," he said, shading his eyes with his left hand, while his right grasped his heaviest stick, "if that is a monkey, then it's in for a devil of a time. If it is not a monkey, then, oh, Lord! $I m$ in for a devil of a time!" The man in the sealskin slippers, which had with difficulty been rescued from the last morass, looked as if he considered the narrative in bad taste. He said that seeing was believing. Someone retorted that believing was sometimes seeing. It depended on the mood. Then the party relapsed into silence. It was quite dark, and everyone was wet and cold and tingling with the onslaught of plant and insect enemies. We had, we found next morning, unanimously resolved that our first hunt for alligators would also be our last. We agreed that alligator-hunting was the limit! 
NATURAL HISTORY NOTES

HERE and there in my Florida notebooks are jottings that, while they fill no particular corner in any of the foregoing pages, I would yet like to include, without, of course, repeating such as have reference to the fishes already described.

There is a crocodile in Florida as well as an alligator. It is a much rarer reptile, and Jack, though the only taxidermist in that neighbourhood, had had but two specimens through his hands. I do not remember seeing any articles of native crocodile-skin in the store at Jacksonville, and in fact the Florida crocodile (Crocodilus americanus), which was discovered not many years ago, seems to be a somewhat mysterious animal. From the alligator (Alligator mississippiensis) it seems to be as distinct physically as in its habits. A glance at the accompanying photographs will help the reader to note the obvious distinguishing characters, the long, pointed snout of the fish-eating crocodile, the blunter head of the alligator. In colour, the alligator is black, the crocodile grey. The alligator

- hides its teeth; those of the crocodile show conspicuously in a groove in the upper jaw. The breeding habits also differ considerably. The crocodile deposits its eggs, numbering less than one hundred, in holes in the sand close to the salt water, smoothing the sand over the top of them. 


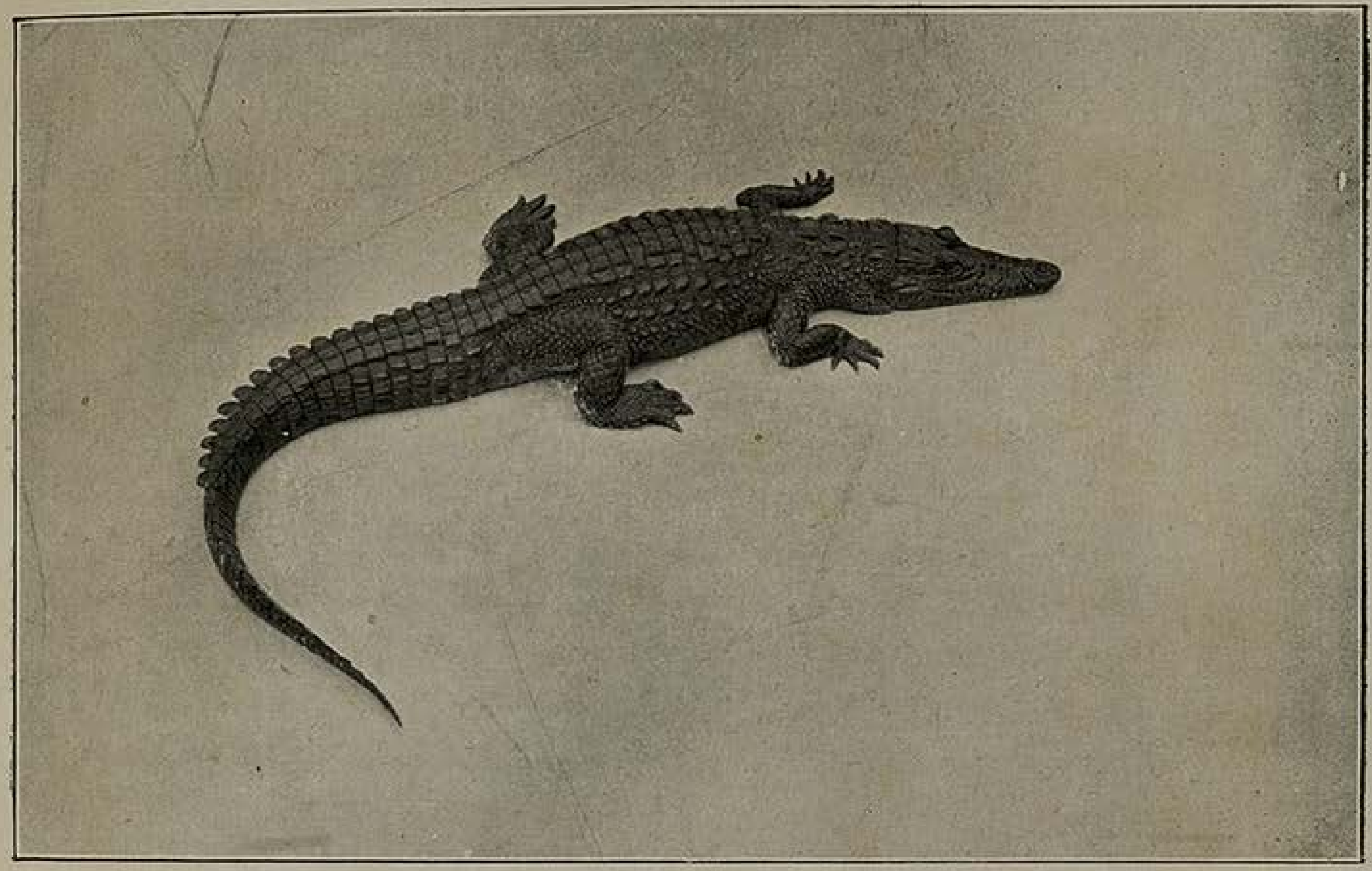

THE CROCODILE.

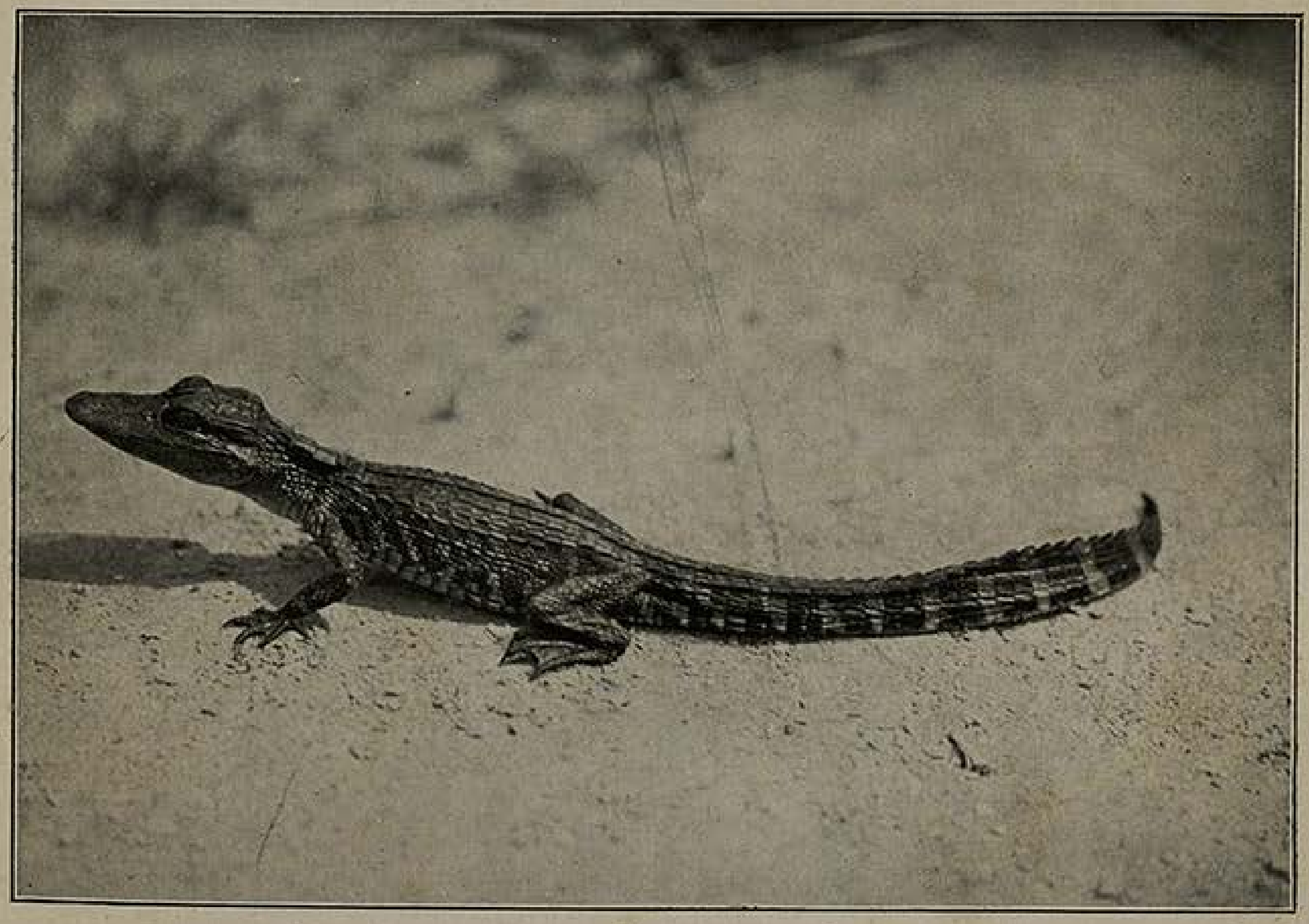

To tace page 164.

THE ALLIGATOR. 


\section{FLORIDA AND THE WEST INDIES 165}

The alligator lays as many as two or three hundred eggs far up country on the banks of freshwater creeks, carefully covering them with leaves and litter in so elaborate a manner as at once to betray them to the eye of the practised hunter. Curiously enough for creatures of such divergent habits, the two are natural and hereditary enemies, and when they meet the crocodile generally defeats his rival.

Of the land-birds of the Keys, the chief are the mocking-bird, whip-poor-will, quail, herons and egrets. The mocking-bird (Mimus polyglottus) is to my way of thinking a poorer mimic than his name suggests, though it may be that, had I heard him in States that afford his powers more practice than the silent land of fish and flowers, I might have formed another opinion. The original music of the mocking-bird is of the sweetest, and his personality, his pert and winning antics, would alone make him a favourite; but his "mocking" powers are, from what I heard, restricted to taking up the challenge if anyone imitates any of the passages from an almost endless repertoire. Back comes the cry, clear and defiant, and the human whistler usually tires of the duet first. This, however, is hardly mimicry, since the bird is but repeating its own song. I have heard it carol against the quail and cardinal close to my hammock at Useppa, but always its own song and never any attempt to imitate theirs. Our homely starling at home, without half the reputation, is twice the mimic.

Writing of mimicry reminds me that the imitative powers of rustics, who occasionally call up duck and other fowl, are very much exaggerated, 
generally, no doubt, by townsmen, to whom, in their ignorance of any beasts or birds beyond the area cat and pavement sparrow, every rural custom has its interest and surprise. As a matter of fact, an ear for music and a little patience are sufficient to enable anyone to reproduce with approximate fidelity even the more complicated tunes of the warblers, while the short, sharp call of quail and curlew are absolutely simple. Why there should have been need of the old "quail pipes," which formerly had a great vogue in England when quail were not so scarce as they are to-day, I know not. One morning as I sat in the verandah, waiting for the rest to turn out, a little quail, of a species common on the island, called out of the palmetto undergrowth not fifty yards away. Half-unconsciously I took up the call, a very easy one, of two notes only, and then ensued a long conversation, always in the same two words, until at last my small friend came running over the sand and peering up into the verandah for a sight of his rival.

I have already had occasion to refer to the manner in which, on our alligator hunt, my guide would stoop beside each "cave" and make a grunting sound like the voice of the seductive reptile within. This I have since achieved without the least difficulty and with a correctness that I imagine demonstrated by the eagerness with which my two small compagnons de voyage invariably responded, on one occasion, in my bedroom at Havana, so affectionately as nearly to bite away the first joint of my little finger in their excitement at recognising a voice from home.

The "whip-poor-will" (Antrostomus vociferus), 


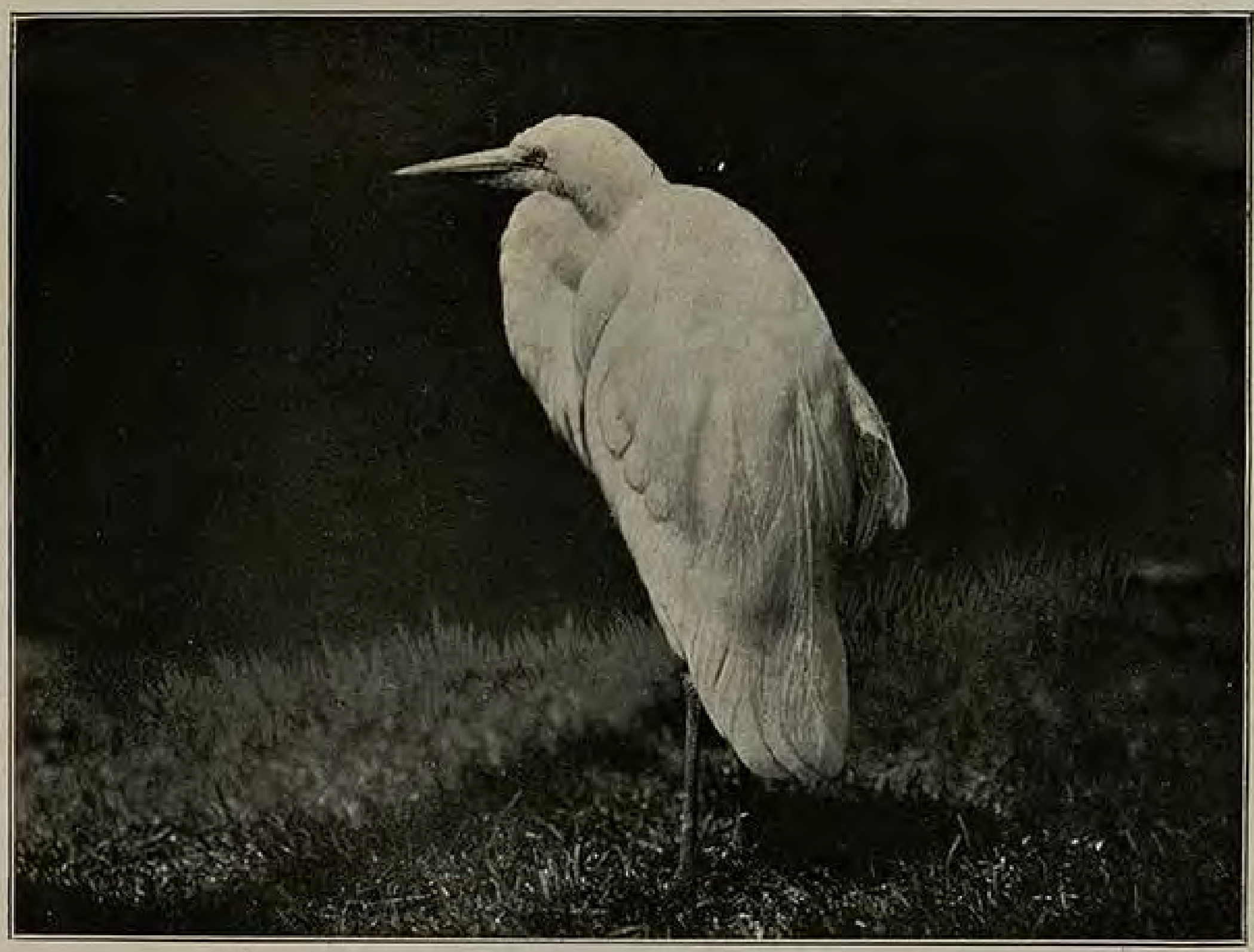

WHERE THE AIGRETTES COME FROM.

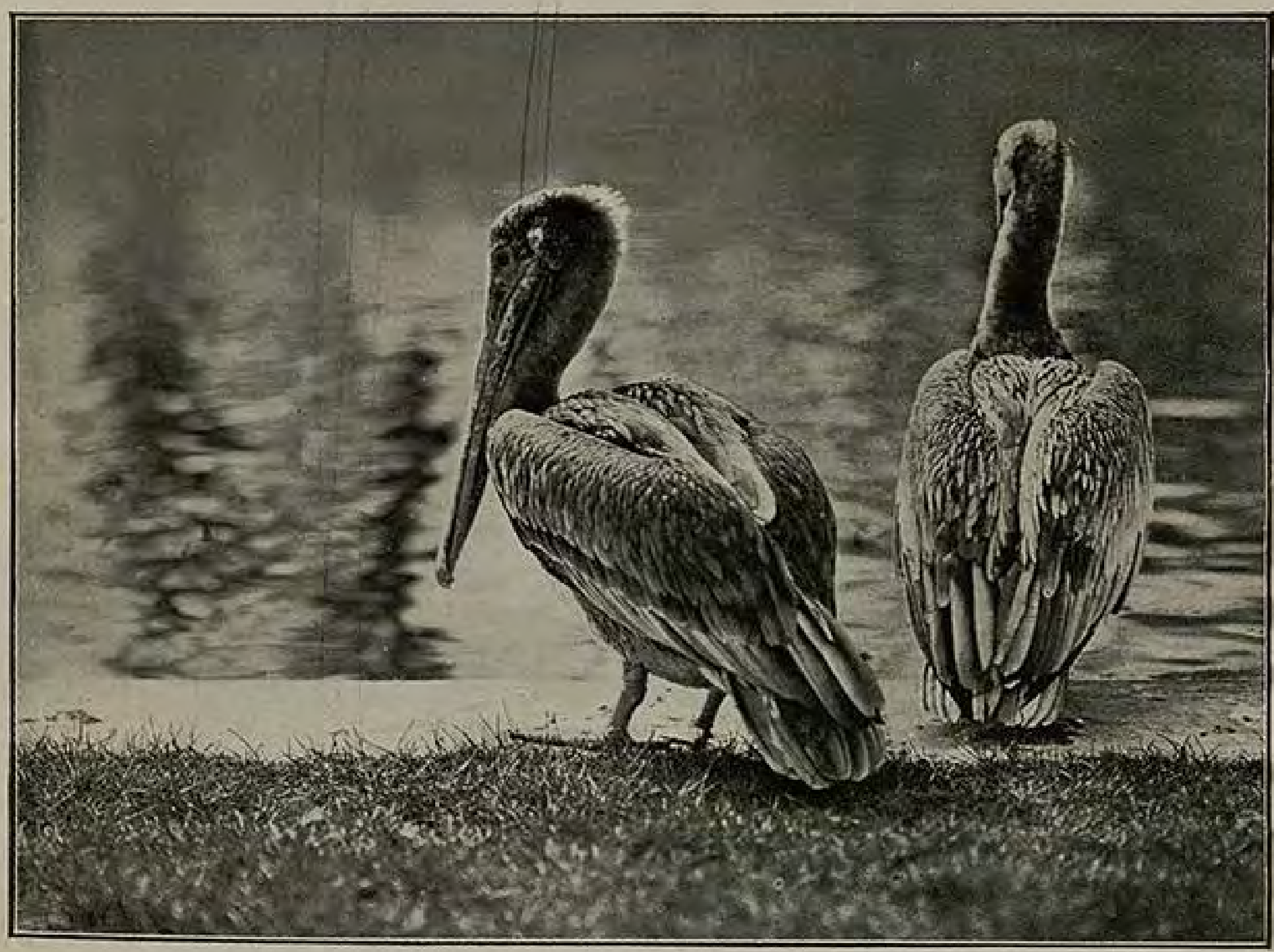

To face page 166 .

PELICANS AT HOME. 
part in both continents, so that to the ornithologist Audubon's Episodes is a volume as painful as the records of those mighty hunters to the sportsman.

Yet, if the numbers have dwindled, the variety remains, and even on the tiny island of Useppa I noticed quail, cardinals, bobolinks, mocking-birds, egrets, kingfishers and half a dozen small winged creatures that I did not recognise.

It is obvious that even to-day Florida is singularly suited to the needs of a large bird population. There is abundance of fruit, cultivated and otherwise, for some, and of fish for others. In the bays and creeks, every acre is like the crowded tank in an aquarium, where the curator is debarred by want of space from giving his fishes adequate room. The hinterland of this silent and sparsely populated region is a wilderness of greenery that provides shady and secluded breeding haunts and inexhaustible resources in the way of insect food. The watery wastes of the interior are interesting only to the naturalist and hold out no inducement to the settler, so that the last home on earth of the Seminole Indian is in great measure deserted of the human race, and is become a paradise in which the birds can live their lives of love and food and battle undisturbed by their tyrant. An hour's lazy drifting among the islands, watching the affrighted egrets peering nervously from their oozy hidingplaces in the mangroves, is an education in the iniquities of the aigrette. To Englishmen at home, who deplore the selfish modes favoured by their womenfolk, there is just the grain of consolation that nowhere are the spoils of this iniquitous traffic more in evidence than in the smart hats that nod 
around the tables at Delmonico's and Sherry's, most seductive of New York's restaurants.

As a matter of truth, the laws passed for the protection of Florida birds are regarded in that country as a dead letter. I know one island, from the rookeries of which spongers alone take hundreds of birds, chiefly the ibis and Louisiana heron, every breeding season, salting down the bodies for consumption during the voyage.

Loggerhead turtles are common in those waters, one at least drifting past our boats during most days in the Pass. No one molests them, and only occasionally is one foul-hooked, when of course it has to be taken to the beach. The turtles increase in number as May advances, for the reason that they come inshore during that month to deposit their eggs on the sandy beaches during the first full moon. The eggs are then left, such of them as are not appropriated by men and bears, to hatch out in the sun. The bear, of which I personally came across no trace, wakes from its winter sleep-which is so light in that genial climate that many authorities altogether question the function of hibernation -in May and comes forth, in poor coat, to feed on turtle-eggs. The reason for so poor a coat is obviously that the mild winter of Florida does not make the protection of thick fur necessary. Yet otherwise, so I was told, the bear is in good condition at the ending of the winter. What, however, is most remarkable is that a very short course of turtle-eggs makes the animal wretched, a result of which I am quite unable to offer any explanation.

The beaches of Gasparel and La Costa, on the threshold of the Gulf, are most prolific in shells, 


\section{70

some of them very beautiful in form and colouring. Tiny Panama shells, larger Pompanos and the heavier conch are among the commonest, and in the course of half an hour, merely while waiting for the slack water, I have gathered twenty or more different kinds, with the names of many of which I am unacquainted. Yet my blissful ignorance of the price-lists of shell-collectors at any rate leaves me the solace of appreciating for their beauty many that may be so common as not to merit even the little trouble needed to pick them up and wash them clean of sand. Of pebbles and stones of any kind, on the other hand, those beaches are singularly free, and you can patrol a mile of the foreshore without finding more than at most half a dozen.

Florida has the reputation of being a land of reptiles. In addition to its tortoises and alligators, rattlesnakes and mocassins are among the deadly snakes that have their home among its swamps and forests. Yet the majority of these crawling creatures, venomous or otherwise, are of a secretive and retiring nature, as may be inferred from the indifference to their presence of the human population. The carelessness of those who share a country with dangerous reptiles is proverbial. I have met cases of this mood in three continents, and it always reminds me of the apathy with which men rebuild their homes on the site of an earthquake or eruption, careless of the chance of recurrence. In the case of indifference to deadly snakes, the habit of the latter in shunning as much as possible the neighbourhood of man is in great measure answerable. A curious case of the kind came under my own notice at Useppa. 
One afternoon in May, when there was no fishing in the Pass, a friend and myself took a stroll over the island, armed only with a butterfly-net and a killing-bottle, tapping tree-trunks and thrusting at palmetto in the hope of dislodging such insect rarities as might therein harbour. Blithely we went in our sand shoes, having been assured that no rattlesnake or mocassin dwelt on the island, tramping over sand and through grass and round the uninviting embrace of prickly-pear. Then, suddenly, we both stood still, and my friend, who was a yard or so in front, drew back only just in time to avoid stepping on a beautiful rattlesnake. Subsequent measurement fixed its length at only thirty-eight inches, but in that first moment of shock I would cheerfully have believed it to be six feet. It was not at the moment coiled for striking, but lay full length, basking in the sun. Eyes met eyes, and the moment we saw it, the snake raised its flat head about two inches off the ground and seemed lost in a moment's indecision. Our own was brief. Doubtless, had we held our hand, the rattlesnake would have vanished, giving us right of way. On the other hand, to spare it meant creepy sensations during the rest of our stay on the island, and, apart from a general mandate to slay such dangerous vermin, I remembered sundry chaff about enthusiastic zoologists hoping to find "rattlers" on an island known to be as free from them as Ireland itself from vipers. Unless, therefore, I returned to the inn with the dead body of the enemy of mankind-how instinctively we give the serpent this position, yet denounce the snake-bound superstitions of the Voodoo worship!-I should be 


\section{I72 SUNSHINE AND SPORT IN}

derided as the victim of Scotch whisky, even though at Useppa that cost the modest sum of eight shillings-and-fourpence the bottle. Down, then, came the butterfly-net over the wicked little head; after which I broke off a couple of feet of the wooden handle and with it beat the head even flatter than it was by nature. That accomplished, we both felt that we had walked far enough in the scrub and that the security of the verandah would be preferable. Such evidence as we carried confuted even the most sceptical ; but the most striking testimony to the interest aroused by our adventure came from the humbler residents on the island, many of whom, both white and coloured, stood in the doors of their cabins and rubbed their eyes as if there were "visions about," uttering exclamations that clearly expressed the deepest astonishment. One lady of the locality informed me that her piccaninnies were in the habit of playing barefoot close to the spot where we found our rattlesnake. Next day took me past her hovel again. Does anyone imagine that, in view of this revelation of danger, the piccaninnies were now shod? Not in the least, but played as merrily and as unprotected as ever.

The truth is that the snakes take good care that their presence shall not obtrude. Was it not the same with the alligators that we hunted in vain on La Costa? That reptile is, in books, one of the fiercest enemies of mankind, lying in ambush for him at river crossings with a fiendish concentration of purpose hardly justified even by the pangs of hunger. Yet for hours we sought this aggressive saurian, knocked at his front door, undermined the 
earthworks of his castle, only to have him slip away unobtrusively by the back entrance.

Of insect life, bar the mosquitoes that on the hottest nights after rain, sang of sleeplessness and malaria, there was little variety. A large species of wasp, more like a hornet in size, occasionally alighted on our boats in the Pass and looked as if, with the necessary facilities, it could do good business, but I did not hear of anyone being the subject of the experiment. Ashore on the islands there was a wretched little pest known as the red bug, so insignificant in size, yet withal so vicious in its attacks, as to recall the harvest bug of September shooting-days at home. A few beautiful butterflies in the vicinity of the lighthouse, where the net was never handy for their capture, and the abundant but elusive fireflies, which flirted round our verandah as soon as darkness had swiftly fallen in a land that knows no twilight, completed the insect list for one untrained in observing such of that class as do not attack his person.

Mosquitoes, both Culex and Anopheles, were plentiful at times, though they never constituted a serious trouble to more than one member of the company, who was endowed with an abnormally thin skin. This he used to anoint with some preparation of asafotida, with the result that he was all but expelled from the mess. Personally, the mosquitoes troubled me very little, as I used my own curtains, a precaution that I almost invariably adopt anywhere near twenty-five degrees on either side of the Line. It was not until my arrival in Jamaica that, having foolishly neglected a practice 
As already related, anxious to catch the steamer from Port Tampa to Cuba, the first stage in the homeward voyage, I had to leave Florida a few days before the rest. Florida had been a happy holiday-ground for a little more than a fortnight. Of its I 200 miles of coast-line I saw only a fragment and that on the west side, and from this restricted glimpse I had to form my idea of the character of this dreamy but fascinating land. Yet those who had known the rest of it all their lives gave me to understand that the scenery is the same east and west, north and south, from the crossing of the border even to Key West, where I had my last sight of it. Coral-keys and low shores fringed with mangrove, not unlike such scenery as I remembered many years earlier in the estuaries of Queensland, watery wastes, silent swamps and desolate jungle are the keynote of the landscape.

The Naturalist, on which I had last embarked in quest of alligators, was now commissioned to convey me back to Punta Gorda. Our original programme was more ambitious, envisaging a start at daybreak and a run of nearly a hundred miles, part of it in the open Gulf, but most inside the keys, to Port Tampa. This would have been I75 


\section{I76 SUNSHINE AND SPORT IN}

interesting, cool and free from risk, and to one who loves the sea and holds all railroads anathema it could not have failed to be a delightful start on the long voyage that would eventually land me in England in six weeks' time. As it happened, the ruthless slaughter of specimen tarpon that week made the taxidermist more than usually busy, so that he could do no more than put me down at the nearest railway dépôt. By the skin of my teeth, and the courtesy of the booking-clerk, I just caught the last train for Port Tampa and settled down to three or four comfortless hours in one of the crowded human cattle-trucks alone available on those unsophisticated Southern roads.

Port Tampa was reached at midnight, so that I may perhaps have missed its beauties, as well as those of its greater neighbour. My only memory of it is a huge jewfish, weighing 335 lbs., which, though caught on the quay that morning, was still breathing fitfully, poor devil, when removed at midnight to the ice-house. Tampa itself, so far as could be judged from its illumination, is, as the Americans say, "quite a place."

The mail steamer Olivette, belonging to the Peninsular and Occidental Company, known in that unsophisticated region as the real and only P. \& O., was alongside the quay and seemed well able to accommodate an immense crowd of American tourists disgorged by the train. Of these the greater number joined at Tampa, and they were bound for Havana to see the celebrations on Independence Day. To see? I ought rather to have said to hear. But this is anticipating the horrors of that function. 
Fortunately the Gulf was smooth, and the small but comfortable boat ran past the southern extremity of Florida and to its island goal within thirty-six hours, which included several spent at Key West and a subsequent slowing down of the engines, as there is no clearing in Havana harbour until after daybreak.

The stewards were without exception Spanish, and it was not until early next morning, when I ordered shaving water and got ginger-ale, that I realised that my Spanish was not that of Cervantes. About the hour of my disillusion we were, so a deck-hand informed me, steaming past the entrance to Boca Grande. Over the intervening waters went my thoughts to the staunch little company even then setting forth, for almost the last time this season, to "'make them jump." Sadly I sat in my deck-cabin, idly turning over half a dozen tarpon scales and trying to picture the doings over there to the northward. The low coast gave no sign, yet I seemed to see them all. That was the end.

At Key West we lay for two or three hours that afternoon, and here, as already narrated, I saw my second American drunkard in a month, for this was the eighteenth of May, that night at Sherry's the eighteenth of April. What a long month it seemed! Surely the tradition that occupation makes the time fly is another of those exploded superstitions that contented a less sophisticated generation. To whom is time so fleeting as to him who does nothing to mark off each day from its neighbours? $\underset{M}{\text { Havana calls herself the "Key of the New }}$ 


\section{I78 SUNSHINE AND SPORT IN}

World," a proud title, better worn in the olden days of Spain's mastery over the Western ocean. To-day there can be no question about the coming greatness of Key West, and on resthetic grounds I shudder at the prospect. Yet the completion of the Isthmian Canal, and also of the railroad connecting this now unpretentious agglomeration of sponge schooners and cigar factories with New York, must inevitably raise it to a foremost position among the cities of the South. Let us hope that, within the restricted scope of its insular possibilities, the beauty of Key West may grow with its wealth. At present, seen at any rate from the wharf, it is so unsightly that, mindful of its future greatness, I forbore from photographing it. I have always thought it the height of cruelty for the illustrated journals to confront queens of the musical-comedy stage and other royalties with brutal reminders of their knock-kneed babyhood. There are some not unattractive private residences further along the main street, beyond the stores, but the face that Key West turns towards the Gulf is homely just beyond the verge of urban plainness. The one human landmark of Key West is a shrillvoiced dwarf, a more than ordinary restricted runt, who meets each steamer and plies his countrymen with chaff and pictorial postcards. $\mathrm{He}$ and the drunken dock-labourer are, in fact, my last memories of Americans on their own soil. I would that this were not so, but the truth compels.

Yet would I rather that my thoughts lingered further West amid the restful isles and drowsy mainland, where, untouched by winter frosts, everything, save wheat, grows rampant ; where man and 


\section{FLORIDA AND THE WEST INDIES 179}

Nature alike drift through existence in unbroken playtime.

"May's warm slow yellow moonlit summer nightsGone are they, but I have them in my soul."

Such is the Florida of my dreams, its flowery bushes alive with the music of mocking-birds, its gleaming waters ever breaking with the splash of leaping fish. Key West, with its cigars and sponges and pushful commercialism, and tourists shouting "to beat the band," is fatal to the spirit of the holiday mood. 


\section{PART III}

\section{HOME BY THE SPANISH MAIN}

CUBA

When the valiant Ponce de Leon went back to Havana from Florida, whither, misguided warrior, he had voyaged in search of the fountain of perpetual youth, he took with him in his side as a souvenir from the Indians an arrow-wound of which shortly he died in the true faith.

I took even less, for a month in the States had brought the exchequer to such a state of coma that it had to be resuscitated by fresh cablegrams immediately on my arrival in the Cuban capital.

I have already related how the all-water route originally planned from Useppa Island to Southampton broke down at the first stage, and twice more on the return journey I found myself consigned to the railroad, with in both cases the solace of most interesting views of typical inland scenery of the Caribbean.

After the crudities of Florida, which, however delightful its sport, is, apart from its few civilised hotels and resorts, a land of savagery, Havana impressed me with its Spanish picturesqueness. Here, once more, the eye rejoiced in gaiety and 


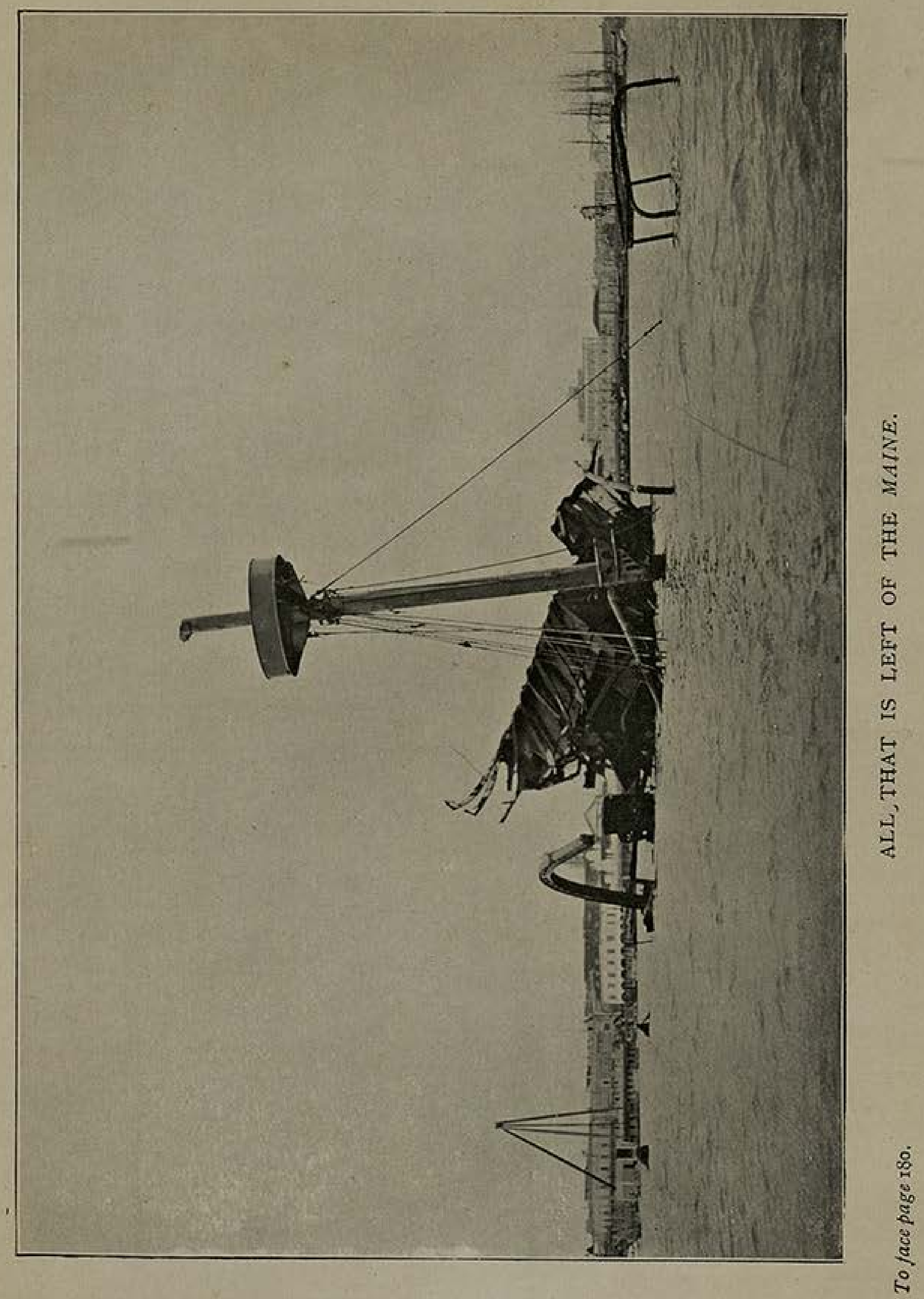




\section{FLORIDA AND THE WEST INDIES I8I}

architecture, in green parks and well-dressed women of great beauty; once more there fell on the ear the strains of seductive music; once more the palate responded to the spell of careful cookery. What a sharp contrast there was between the palaces and gardens and languorous beauties and discriminating epicures of this beautiful seaport and the shacks, backyards, slatterns and gluttons with the catholic appetite of the hornbill that I remembered in Florida! In all my travels there are few lovelier pictures than that of Havana harbour at sunrise, the golden rays lighting first the coloured roofs and then the deserted quays, and last of all the wreck of the ill-starred Maine, and gilding gaily-painted little craft that dance out under the oars of the guadaneros to meet the steamer as soon as she has passed beneath the frowning Morro.

She is soon boarded by the usual posse of fiscal and medical inquisitors, the latter making a searching examination of our health by walking, hat in hand, through the saloon in which we muster for his visit and then, after accepting a cigar from the captain, returning down the gangway to his launch.

Then, as the Olivette drew to her moorings, came the inevitable struggle with hotel touts. As all the tourists on the boat are bound in a body, personally conducted by an official of the P. \& $\mathrm{O}$ (ccidental) Company, a man of extraordinary local information, for the Hotel Pasaje, I allow myself, with simulated reluctance, to be carried off by the emissary of the Inglaterra. We go ashore in a tug, not because there is not water enough for steamers of far greater draught alongside the quay, but 
because there is a fat monopoly of lighterage that even the Americans have been unable to combat. Thus it is that Havana, one of the grandest harbours in the West Indies, has no more berthing accommodation than a Cornish tidal port.

The brief but pregnant halt at the Machina (Customs) enables an official of subordinate station to detain alike my rifle and my alligators. The living contraband was immediately released by his superior officer, but the rifle was firmly but gently detained. The comic-opera Government installed in Cuba by the Americans is, as events have shown since I was in the island, unable to run the risk of imported rifles, and all such weapons are in consequence strictly detained at the port of entry. Only - thanks to the help of $\mathrm{Mr}$ Griffith, H.B.M. Vice-Consul at Havana, who gave me an introduction to the head of the Customs, a charming man, who spoke French, understood English, and finally took my word that I was proceeding direct to Jamaica, viâa Santiago-was I able three days later to effect its release. As I explained to the official in question, the rifle, only an inexpensive sporting Winchester at best, had been in my possession for ten years, so that its intrinsic value was not worth a moment's thought; only, having never, in the whole course of our acquaintance, hit anything with it, I particularly desired to retain it on the chance of eventually putting it to its legitimate use. He suggested grimly that there were many uses for rifles in his country, and the newspapers have since thrown new light on his meaning. He also hinted that many people in Havana would be happy to relieve me of it, and 


\section{FLORIDA AND THE WEST INDIES 183}

that it was on my head to get it safe out of the island. I vowed never again to lose sight of it until there was salt water between me and Cuba, and I kept my word. As I gravely stalked to a $\mathrm{cab}$ with the precious rifle under my arm, it was evident from the salaams of the police and gatekeepers that I was mistaken for a personage.

A very short acquaintance with this fascinating city convinced me that not all Roosevelt's roughriders and Dewey's bluejackets could expel Spain and Spanish ideals in more than name. Politically, Cuba may be independent of the beautiful land that lies between the Pyrenees and the sea, but it remains more Spanish than American. I had left the land of hustle for that of mañana. Before I left the boat, I surrendered my keys to a particoloured official of the class that Americans designate "Spiggoties" (i.e. from their refrain "Me no spiggoty Inglis"), an attaché of one of the Express Companies, who swore, for the modest sum of four dollars ( $16 \mathrm{~s} .8 \mathrm{~d}$.), to see my baggage through the Customs and deliver it at the Inglaterra not later than half-past nine. It was then about seven o'clock, and I cheerfully repaired to the hotel, immoderately breakfasted at the "Miramar," the best eating-house in Havana, and unsuspiciously returned to the other hostelry for a bath and to await a change of raiment in the privacy of my room, shared only by the alligators. I looked for the momentary arrival of my luggage from nine until three in the afternoon, spending the interval in demonstrating to the faithful companions of my troubles that essays in biting hurt them more than me. 
By four, famished for lunch, but unable, in the absence of clean clothes, to venture forth any sooner in quest of it, I was clothed again, and walked down the O'Reilly and other gay and busy thoroughfares. These are flanked by alluring shops with well-dressed windows and bearing such remarkable names as $\mathrm{La}$ Esperanza (esperanza no doubt of fat sheep coming to the shears), Las Ninfas (singular name for a dry-goods store), and such like. Later, after a ramble round the shores of the harbour, which wore fresh beauties in the afternoon light, I drove out to the great cigar factory of Messrs Upmann, to whom I had introductions, and then I strolled down the shady Prado back to the Miramar, where an excellent, if expensive, dinner at a window table, whence I could watch the youth and beauty driving by in carriage and motor and listen to the admirable military band playing on the Malecon, still further restored my self-respect and love of my neighbours. This return to eatable food was perhaps the relief for which I gave most thanks. Here indeed was a reprieve after the crimes of the Useppa nigger, who was given the most meagre of material for his magic, and who would, I vow, have made but an indifferent conjurer even with the resources of the Ritz.

That day and the next the city was en fete for the celebration of Independence Day. On this festive occasion I was with the emancipated Islanders in the body, but not in the spirit, for they twice turned night into day, and earth into hell, by exploding unremitting salvos of squibs, crackers and maroons for a period of thirty-six hours. Two nights I lay writhing on a sleepless bed, praying 


\section{FLORIDA AND THE WEST INDIES 185}

for a Spanish squadron to drop anchor under the Morro and land Spanish troops that might on this careless holiday undo all the work of the war. If this, I argued in my midnight wrath, was the only way in which the Cubanos could celebrate an independence that they owed to others and would never have wrested for themselves, pity was that they did not still depend. Fortunately the heavens, tired of the mock artillery of fireworks, treated the capital that Sunday night to such a display of blinding lightning, deafening thunder and drowning rain as put a term to the witches' sabbath in the fast-emptying streets.

Much of the uncouth revelry of this anniversary is aided and abetted by well-to-do young students, who are the moving spirit of this unclean gala. It was at their hands that during the celebrations I was the unwilling witness of one of the most revolting cases of horrible cruelty to animals that ever came to my notice. A party of this gilded youth, fifteen or twenty in number, had tethered an unfortunate large living crab to a string and were dragging it over the hot pavements. This in itself must have been most painful to their cold-blooded prisoner, but it was as a mother's caress beside what, to my amazement and horror, I next saw. A squib was inserted in one of the claws and exploded with a terrific concussion that could have been nothing short of dreadful agony. This was repeated again and again until, looking round in vain for one of the police (who, to my knowledge, are bound, if called on, to interfere in such cases) and not feeling equal to the task of bringing my enigmatical Spanish to the defence of the unhappy 
one, I hurried in the opposite direction. I should have liked to be able to say that, risking the certainty of ridicule and the probability of a knife in the small of my back, I rushed in and rescued the crab at the point of my cane; unfortunately, candour compels me to admit that I did nothing of the kind, though I doubt whether any infliction, moral or physical, could have hurt me more than the haunting memory of the sufferer for the next few days. I afterwards learnt that even an appeal to the police would in all probability have been inoperative, resulting only in my detention in the island for being mixed up in a street disturbance, and in the weight of the testimony of fifteen liars against my own, for these youths, allowed unlimited pocket-money by well-to-do parents, spend no inconsiderable portion of this unearned increment in bribing the myrmidons of the law to wink at their peccadilloes. Fiat justitia! Cuba is great, and if these students are a fair sample of the nation that Uncle Sam has liberated from the yoke of Madrid (probably they are not), he might perhaps have used his men and ships to better purpose. It might be thought that the liberators of Cuba would be hailed as saviours by the freed. I cannot truthfully say that this seems to be the case. Two Cubanos of widely different station, the one a wealthy merchant, the other an hotel dragoman, described them to me as vulgar fellows who flock to Havana as if it were a wild-beast show and cash a five-dollar bill so as to jingle the change in their pockets and impress the natives with their wealth. In fairness to both parties concerned, it may be pointed out that, while a number of charming and 


\section{FLORIDA AND THE WEST INDIES 187}

intellectual Americans reside in the island, these most in evidence are the cheap brand of tourist already incidentally mentioned in these pages, the stamp that we at home, in deference to their restlessness rather than their grace of movement, call "trippers," or what the West Indian nigger euphoniously terms "dam fool Cook." Most countries have these joyous holiday-makers, and in Anglo-Saxon communities they are seen and heard at their worst. One might as fairly judge the English nation by a first-Monday-in-August crowd on Margate Sands as the people of America by some of the dreadful republicans that cruised with me to Cuba. One of their number, a "lady-drummer," I shall never, alas! forget. The whole of our afternoon at Key West she waved the Stars and Stripes over me. Next morning her behaviour was like that of the emblematic eagle, and she seemed to fasten her claws in the soil of Cuba and spread ragged wings over the new republic. She harangued me on the greatness of her country and countrymen, which at first I was only too ready to concede, until, just as we came abreast of the Maine's topmast, she goaded me into saying (what I did not for one moment mean) that Washington dared not sanction the raising of that historic wreck for fear that the world might share the knowledge of the divers that the explosion, the pretext of the war of liberation, came from the inside. That heresy dammed the torrent of her jingoism, and I thought forone moment that she would rend me where I stood, but, instead, she tottered a way, leaving me free to assure her compatriots that my hypothesis had been the last resort of a desperate man to free himself of their terrible 
advocate. I want to forget that commercial traveller in petticoats, yet I like to remember her as the justification of Havana's bad opinion of her countrymen, which would otherwise savour of base ingratitude.

On the Sunday afternoon, having breakfasted in my favourite window-seat, which the handsome waiter at the Miramar-a cross between $\mathrm{Mr}$ Lewis Waller and $\mathrm{Mr}$ C. B. Fry, and the most athletic looking Cuban of my acquaintance-regularly kept for me, and having then read some European papers at the German Club, of which Herr Upmann was so good as to make me free during my stay, I drove out to the great hall of the Fronton to see a tournament of Jai Alai, otherwise my old friend Pelota under a provincial name. It was the old game that I used to watch at Biarritz. There were redoubted Spanish players in the programme, and the play was, as it always is, bewilderingly fast. First, two blues opposed two whites in a partido, thirty points up; then there was a quinielo, an allagainst-all mélée in couples, six points to win. As in tennis, fives and other games, scoring is only by the opponent's miss.

This is undoubtedly one of the finest spectacular games ever devised. To enjoy watching cricket or golf, some understanding of the game is essential, but pelota, in which the ball is sometimes on the move for five minutes before a point is scored, is most exciting even to those who know nothing of the rules. Equally, it is a game only for professionals, who are entered to it in their boyhood and who, if they come to the front rank, earn several hundred dollars a month. A few ambitious 


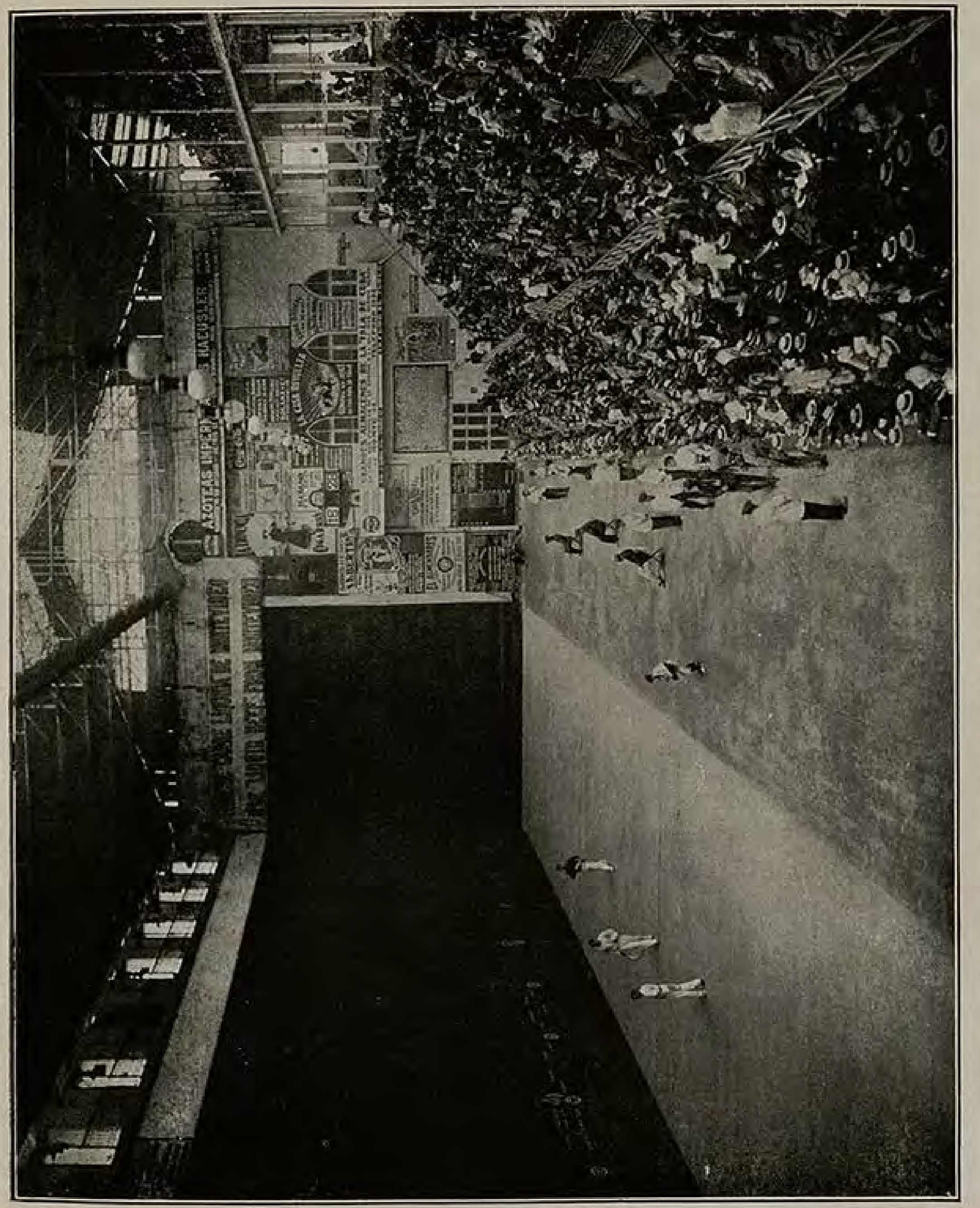

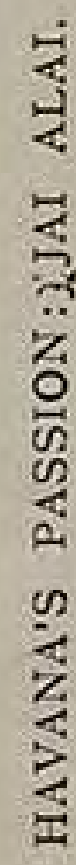

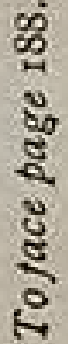




\section{FLORIDA AND THE WEST INDIES I 89}

"sports" do, I am told, make a feeble attempt to attain proficiency, but an early start and unremitting practice during a long apprenticeship are indispensable preparation for the dexterity, nothing short of marvellous, with which the champions of the game wield the curved basket, which, so to speak, prolongs the right arm into an imitation of an elephant's trunk.

While it would be difficult to overpraise Jai Alai as a spectacle, there is little doubt that it is heir to all the evils that beset purely gladiatorial games. One of the matches that I witnessed was (unless I am much mistaken) a clear case of sold to the bookmakers, or Corradores, who, easily distinguished by their red caps, are too much in evidence in the arena and right in the way of those in the front row, lisping the odds as each point goes up on the board in a most infernal din. A very courteous Spaniard, who sat next me in the front row, had enough English and good nature to explain the game to me, and the fact that I knew its peculiarities already did not make his intentions less kind. In the course of his running commentary on men and things he gave me a shock. I asked whether my suspicion that the last game had been "pulled" might by any chance be correct. $\mathrm{He}$ shrugged his shoulders and said that the whole display was for gate-money and gambling. In a rich country like England, he added with a sigh of envy, we could afford to play our games for pure love of sport and not for business. I half thought that he must be laughing in his sleeve, but he spoke in obvious and genuine admiration of the austere purity of all English games. With some attempt 
at modest deprecation, I accepted the apologia (on behalf of Football) and felt myself blushing.

The great hall was packed and must that afternoon have seated its full allowance. During the interval between the partido and quinielo my new acquaintance took me into the ring, where we conversed, or rather he conversed and I looked interested (not understanding one word in ten), with one or two of the darlings of the crowd, who, perspiring freely after their strenuous game, were drinking limonata and other mild refreshers.

The most delightful evening ramble in the city is along the parade beyond the Malecon, watching the play of lights on the entrance to the harbour and listening to the band play the Paloma and other novel airs.

As the moon shone over the Morro, lighting on ghostly ramparts that guard the harbour's mouth, or perchance on the bronze maiden who dwells on the roof of the old fort, little pleasure-boats, each hooded with an awning, would shoot out from the dark cliffs with a merry, tuneful freight of men and maidens. Then I would stroll homewards, making a détour by way of the old cathedral, which enshrines a few of the many bones of the intensely vertebrate Columbus. Dear dead explorer! He was buried in even more places than saw his birth, and he must have been a bonier hero than even old Atlantosaurus immanis! En pas descana!

The temperature of Cuba in the month of May, something just the right side of $80^{\circ}$, is never unpleasantly hot, though I have no desire to discount the tortures of the American volunteers who camped in the scrub on half-rations, fighting a fight 


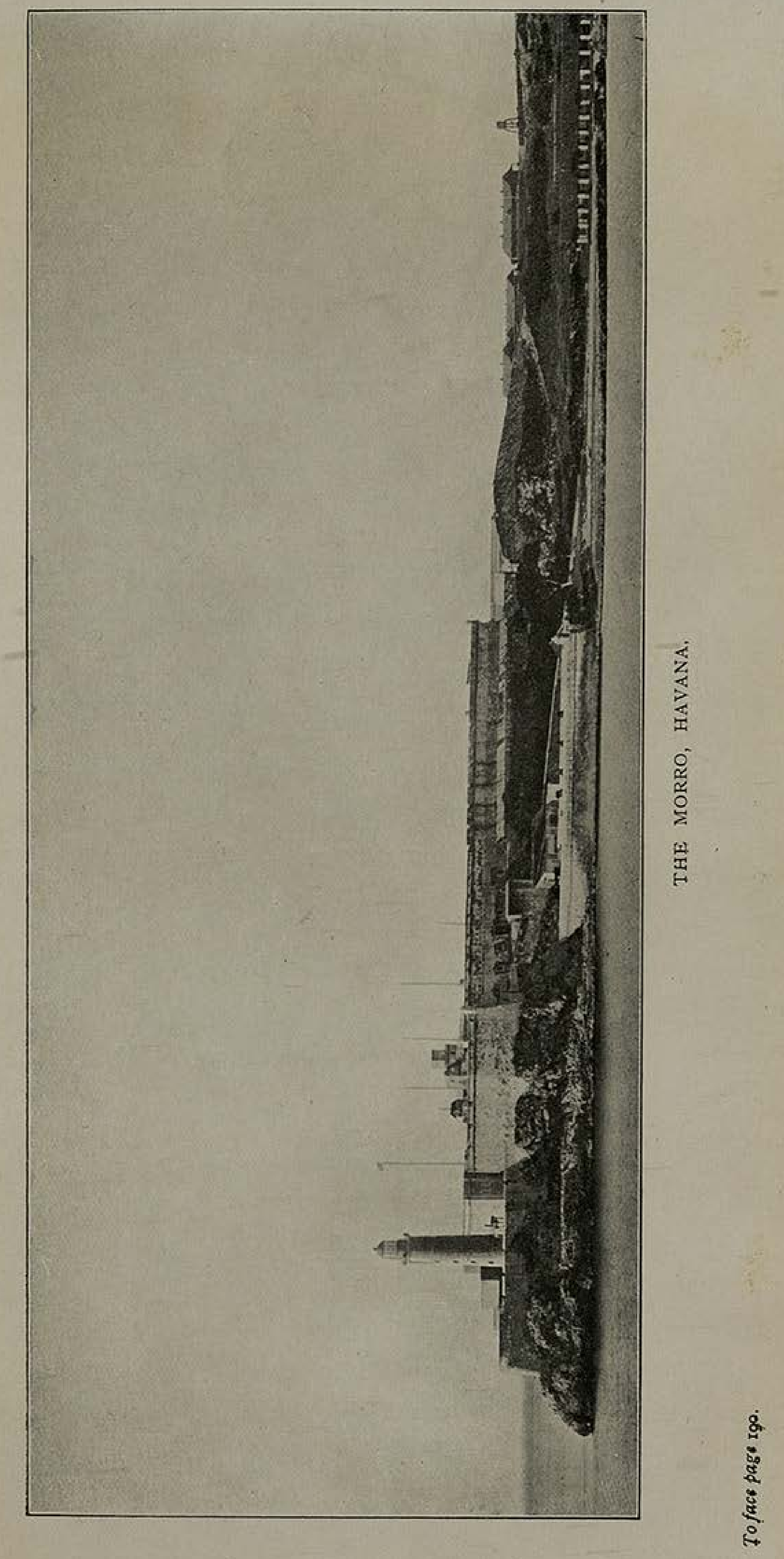




\section{FLORIDA AND THE WEST INDIES 19I}

that was not theirs. In peace time at anyrate, the climate was merely hot enough and dry enough to crowd the thousand cafés of the capital with noisy candidates for ensalada, pina fria and other simple but cooling beverages of a land where there is much drinking but no drunkenness. The Cubanos, even more than their cousins of Spain, have a passion for ices and sweet cakes, and men, who in London would be drinking whisky pegs in their clubs, gravely sit in the cafés and put away cream cakes and jam tarts with a wholeheartedness that would shame a schoolboy home for the holidays. Such sugary food is better suited to the fair, yet these never gladden such public resorts with their presence, though they may, for all I know, have their allotted haunts.

When it rains in Havana, it rains. That is to say, the streets are transformed to lakes and rivers with the swiftness of a change effect at the Hippodrome, and those who are unprovided with umbrellas stand weather-bound under the arcades waiting for a lull in the storm. Mosquitoes are apt to be troublesome in rainy weather, but the hotels have an ample supply of damaged mosquito-curtains. He who likes the comfort of nights immune from such tortures takes his own.

It is possible to reach Santiago by sea-it is possible, when one comes to think of it, to travel in the same manner from New York to San Francisco-but few, I imagine, are so eccentric. The railroad journey is certainly a long one, occupying twenty-four hours by schedule, with three hours' grace several nights of the week, but it is certain (which is more than can be said for 
boat service in that part of the world) and, during the daylight stages, picturesque.

The train leaves every evening at nine, and a comfortable sleeper is provided, with Cuban conductors who speak French, the French of Havana. The journey is made under the auspices of two companies, the United Railways taking the traveller as far as Santa Clara, which is reached early next morning, and the Cuba Railroad taking him to his destination before midnight.

The scene on either side of the carriage cannot perhaps lay claim to continuous beauty, and as a matter of fact, so far as this particular train is concerned, the environs of both terminal cities, the most picturesque fragments of the journey, blush unseen in the darkness of night. On emerging from his berth in the morning the traveller will probably find himself moving through fertile country overgrown with rich guinea-grass and displaying at short intervals small patches of tobacco, generally in the neighbourhood of dwellings. The serious cultivation of this insidious narcotic is restricted to the province of Pinar del Rio, which is reached by another railroad, and which may be remembered as having acquired some notoriety in the recent revolution. The little patches of tobacco that we see between Havana and Santa Clara are merely tended for home use. Every Cuban goodwife worth her salt can roll a cigar from the dried leaf (which is kept on a shelf in the kitchen) like an artist, and her lord and master, returning from his day's labour at the sugar-mill or among the cattle, can enjoy a freshly-twisted fragrant weed that 


\section{FLORIDA AND THE WEST INDIES 193}

many a connoisseur in eastern cities might envy him.

At Santa Clara we transfer, without changing train, to the system of the Cuba Company, and the scenery soon displays greater variety than in the earlier stage. Wild tangles of virgin forest push their claims right up to the single line laid by British enterprise through the heart of the jungle, and mahogany, logwood, lignum vitæ and other valuable lumber lies in heaps in the clearings waiting for transportation to the coast. In some of these breaks in the forest lie slender trunks of cedar, and may I never again open a new box of cigars without remembering how Nature aids and abets man in the most venial of his vices by planting the aromatic cedar beside the delicate leaf that it will one day protect from deterioration in a climate more suited to frogs than cigars! On all sides there are the unmistakable signs of agricultural prosperity, and indeed, thanks in great measure to the ungrudging investment of American capital, the tobacco vegas are equipped with every improvement, and all the newest plant has been introduced in the larger sugar-mills. It was in its lack of capital, rather than of enterprise, that much of the railroad scenery of Jamaica struck so unwelcome a contrast with that of Cuba, rsthetically its inferior. Were sterling as freely sunk in its soil as dollars in that of the more northern isle, it need not be one whit less prosperous.

At Ciego di Avila the company makes the most of twenty minutes in an attack on an excellent breakfast of meats and vegetables, guavajelly, cold fruit-pie, with a wash of white Rioja and 
coffee, and it is surprising how much can be done in so short a time to keep the wolf from the door. These restaurants along the tract are run by a Chinaman, with the racial genius for catering, and he happens to be on this train, a merry fellow, sleek, sociable and eloquent in pidgin-English.

Repletion, added to the heat, made me somewhat oblivious of the scenery during the afternoon, but I recall a general impression of sugar-canes and bananas, with the feathery palm waving over the meaner luxuriance of fern and palmetto, but for the distance of the unimposing mountains, strangely reminiscent of another railroad jaunt eleven years earlier to Buitenzoorg, the gem of Java.

The landscape is, for the most part, of unbroken flatness, contrasting in this respect with what I was to see a week later in the neighbouring island. Such unpretentious hills as rise above the horizon are far away to the south. Of running water there is therefore little evidence, and the eye rests more often on muddy lagoons, dark haunts of the black maja, nurseries of the mosquito and concert halls of frogs innumerable. Bird-life is far more varied and abundant than I saw it in the Southern States. The turkey-buzzard, a useful little vulture that kept pace with my wanderings as far as Barbados, the last port of call before Britain, is still conspicuous, wheeling in the air or strutting beside the track, finding no difficulty about earning its modest wage in the country districts, though it is fallen on hard times in Havana city, thanks to the cleansing reforms carried out in its streets and squares by Colonel Gorgas and Dr Finlay. There are also 
many smaller fowl, of which gaudy plumage, raucous voices and long tails seem to be common characters. Dragon-flies hawk untiringly over the breeding haunts of mosquitoes, their iridescent wings vibrating in the bright sunshine. Butterflies, in which orange and lemon-yellows are the prevailing tones, float beside the train. Of wild quadrupeds there is no sign. Cuba's only indigenous beast of any size, the hutia, I saw only in the queer little museum in the Cuba Street, Havana, where a couple of indifferently embalmed specimens languish behind glass in the mournful company of other libels on the local fauna. The only other alleged "wild" beasts are the feral deer and boar, which have taken a leaf out of the Cubano's diary and thrown over their allegiance to man.

Human dwellings cluster round the stations. There is not, as in Java, a teeming population of natives generally distributed over the interior. There is a population of under fifty to the square mile as against nearly four times that number in Jamaica. In consequence, the interior of Cuba gives the impression of being sparsely populated, and indeed the area would support a very great increase. What chiefly strikes one in this respect is the occurrence along the line of settlements of foreign labour, Canadians and others congregating together and contrasting in their powerful physique with the weedy Cubanos. Down in the Santa Cruz cattle district on the south coast there is one that owes allegiance to far-off Sweden. The clean, substantial dwellings of some of these exotic contributions to the population are easily distinguished from the tumbledown thatched huts of the coloured 
natives. Quaint carts, drawn by teams of bullocks, toil patiently along the scratches that men hereabouts call roads. Breedy little cobs, with traces of barb ancestry in the head and neck, but with coats seemingly ruined by ticks, are drawn up at every siding, and the Cuban in the saddle has all the opera-bouffe picturesqueness of the Doré Don Quixote. Horsemen and footmen agree in a liking for the machete at the hip, a serviceable weapon invaluable in cutting down jungle or anything softer that may be in its owner's way. I understand that the Cubano is less ready with this knife of his than some friends of mine in the south of Europe. Possibly the enervating Caribbean climate may have dulled his lust for blood. At intervals along the line comes the unmistakable smell of raw sugar, soon after which warning the train draws up beside a busy mill and puts down passengers or machinery. The finest of these mills is one erected by the Cuba Company, and round it stand the substantial dwellings of the English and American overseers.

Agriculture, producing chiefly tobacco, sugar and fruit, is the mainstay of the island, but cattlebreeding, with stock from Texas and the Argentine, flourishes in the neighbourhood of Santiago, and guinea-grass waves high and strong beside the track, its luxuriance seriously hampering the upkeep of the permanent way. The one evil that the railroad engineer in the tropics dreads perhaps even more than heavy rainfall, in his care of a lightly ballasted line of not very modern construction, is the invasion of grass, for it makes the rails slippery and causes the engine to race. Such 


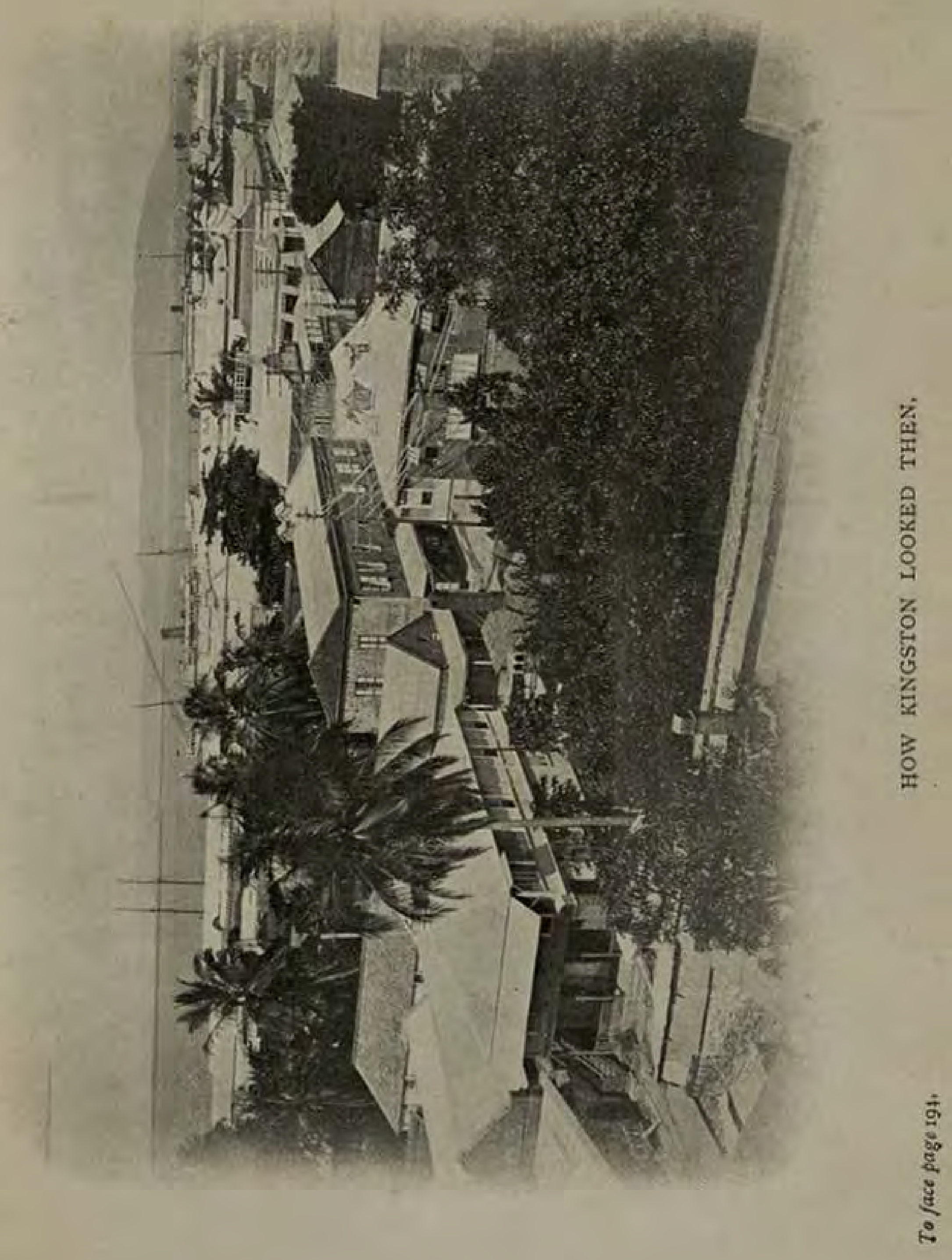




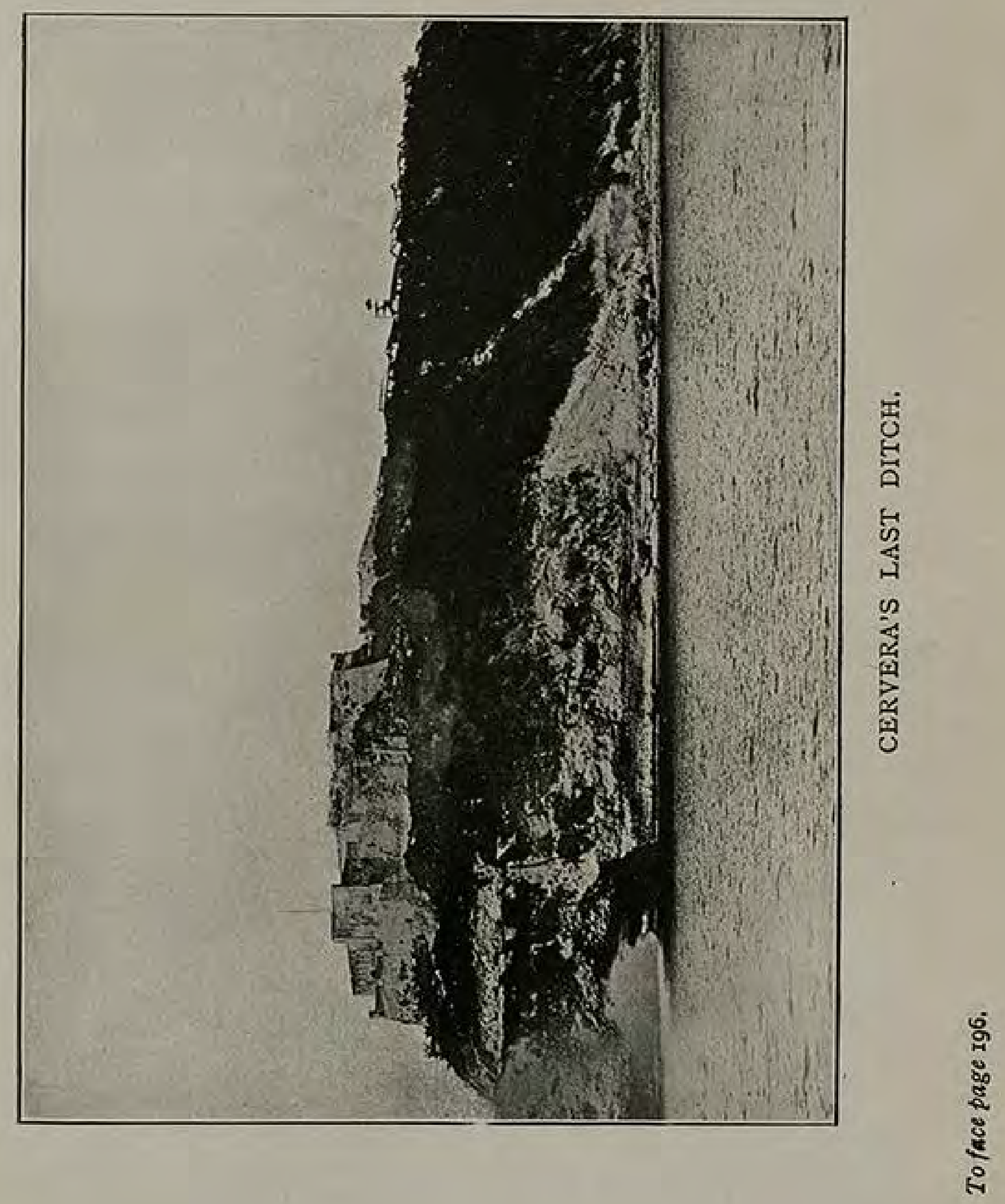


difficulties compel Cuban engine-drivers to proceed with caution, but if the pace is gentle, there are at any rate few wrecks.

Santiago reached just before midnight, I proceeded to the Hotel Venus, a rambling barrack with a beautiful courtyard and indifferent cuisine. It stands next the cathedral on one of Santiago's many hills, which make the eastern port so much more picturesque in its way than Havana. The harbour is also larger, and the Morro commands it from a greater elevation. Shades of Medina Sidonia! What a defence an efficient fleet might have put up in such an arena!

There is nothing of interest in the cathedral, which seems to have been looted of all the treasures claimed for it by older writers. I was told, with what truth I know not, that Madame Adelina Patti made her début here, and my thoughts flew back to the "Shadow Song" in Dinorah five-and-twenty years ago, my first night of Grand Opera - and what a first! This musical memory must be the city's chief pride, for there is nothing edifying in the continual warring of pirates and patriots.

The Oteri, a nice little boat, with a Spanish skipper and American purser, made the calmest of crossings, the narrow seas being that night like a lake. By ten next morning, followed close by the R.M.S. Orinoco, homeward bound from New York for Southampton, we passed the Quarantine at Port Royal and drew alongside the Kingston wharf. Port Royal had a wicked reputation in the bygone days, but this morning it looked virtuous and deserted, and indeed the recent withdrawal of 
the military must have made a difference to its gaiety. The young ladies of Kingston, in whose eyes the United Services are maintained solely for their social talents, resent this stern decree of the home authorities bitterly. With woman-suffrage, the peace establishment of the island would undergo some changes. 


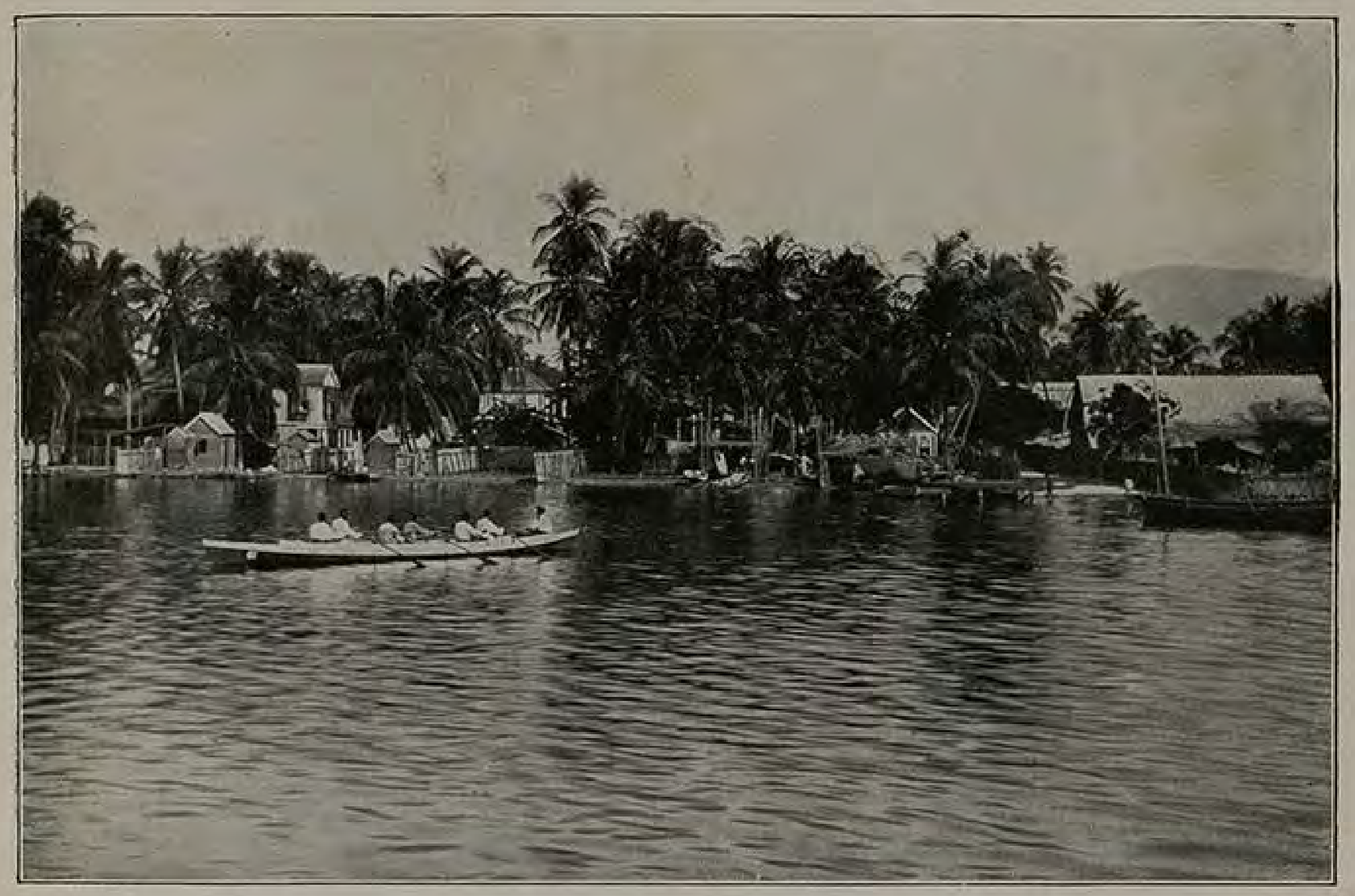

AQUATICS AT KINGSTON.

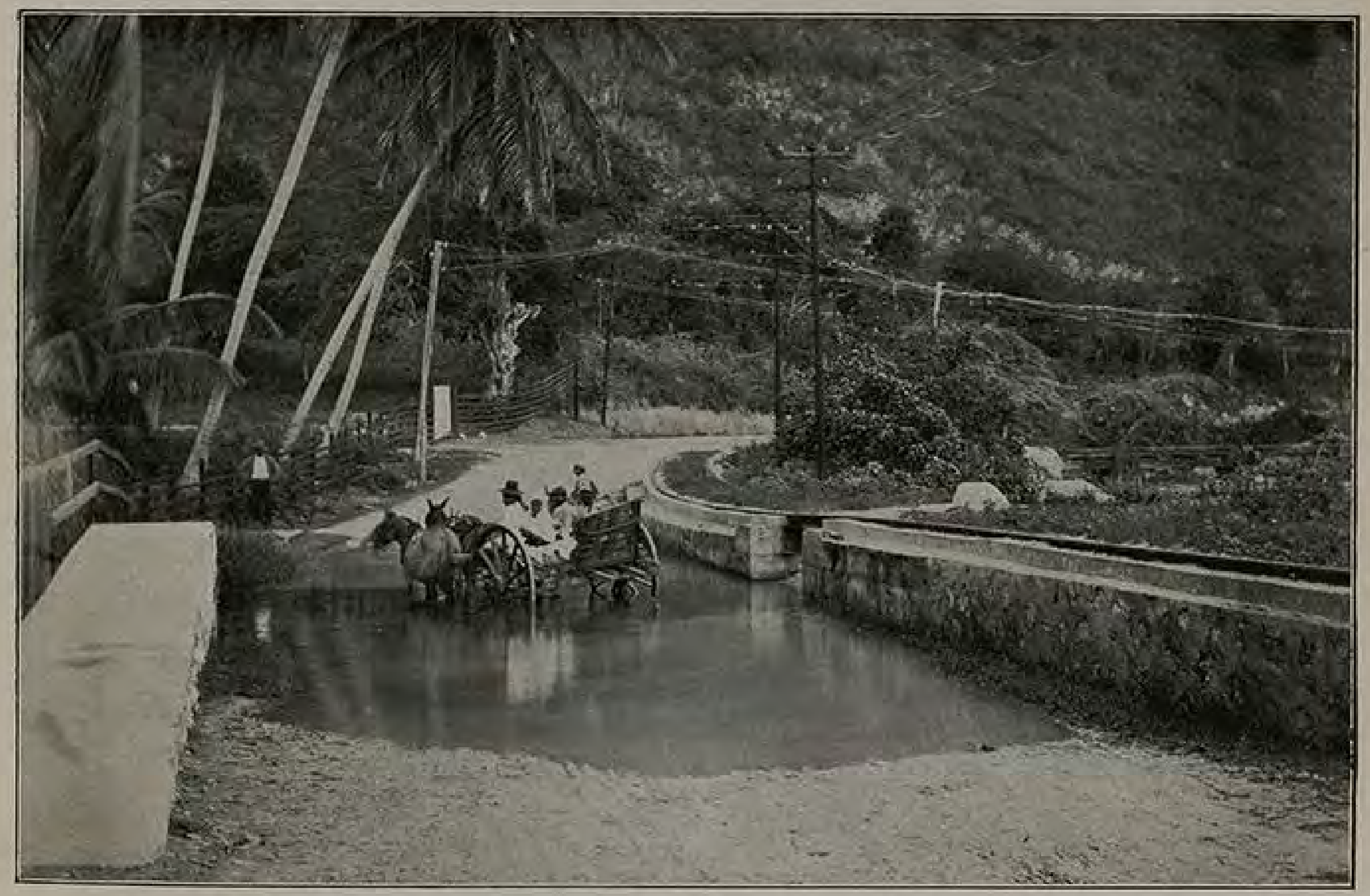

To face page 198 .

A WATERHOLE NEAR KINGSTON. 
ONCE again the Union Jack floats over the Government buildings beside the quay, welcoming eyes that have for many weeks seen first the Stars and Stripes, its younger cousin, and then the ensign of an island independence, of which the days are surely numbered. Travel is the Englishman's best tonic, and it inspires a sturdy patriotism of broader ideals than those preached beside the parish pump.

The wide divergence between the standards of both great branches of the Anglo-Saxon race is nowhere, perhaps, more appreciable than when the traveller, fresh from the teeming parallel hundred and fifty hives of New York, comes to anchor before the dreamy verandahs of Kingston. The American thanks his Stars that he is not doomed to drone his only life away in such a backwater. The Englishman thanks his God that he is at home again, given time to collect his thoughts without being pushed off the pavement, brought in contact with a working class that does not meet every behest with "Say, boss ....!"

It has been said that America casts a covetous eye over the whole of the West Indies. I doubt her conceiving such an ambition even more than I doubt her realising it. That she must eventually acquire $\mathrm{Cuba}$ is a foregone sequel of the war as the result of which she installed a tinsel Government 
more appropriate to the boards of the Savoy Theatre. The recent history of the island has sufficiently demonstrated that the present Government cannot indefinitely endure, and, with so considerable a commercial stake in the country, America could not, while indifferent to the trifling disturbances not long ago put down by the President, afford to see the blaze of a protracted civil war within a night's steam of Key West. The first really serious revolution will be the signal for a political change on the atlas that might, but for appearances, have followed directly after the surrender beneath the great tree outside Santiago. It would have hurt the pride of Spain less to renounce her rights in favour of the nation that really wrested them from her, and to force her to make way for her former subjects was a needless refinement of cruelty, the more so as such an arrangement cannot possibly be permanent.

Cuba is as good as American to-day, and the island will benefit in every way when the change of ownership is acknowledged in name as well. But that Jamaica should be drawn into the Union is highly improbable. There are, it is true, Englishmen in the island (and still more Englishmen at home with pecuniary interests in the island) who fervently desire such a transfer, and before too bitterly condemning their want of patriotism we shall do well to realise the extent to which they may have been goaded into this attitude by the contrast between British apathyand American enterprise. Under the British flag American capital has free play and a fair field without favour. The money invested in the island by the United 


\section{FLORIDA AND THE WEST INDIES 2OI}

Fruit Company alone, not to mention tourist syndicates in which Americans control the whole of the capital, must be very large. But it is inconceivable that Great Britain would, with the fleet at her disposal, let anyone rob her Caribbean tiara of its brightest jewel. Nor would the American régime be tolerated within the island. It is worth bearing in mind that the black population outnumbers the white by at any rate five or six to one, and the nigger has no use for an American occupation of the island. He likes the American tourist, who throws him a "quarter" where an Englishman would hand him sixpence, but he likes an English master better than an American boss.

The Jamaica nigger is less of a problem than his brother in the States, nevertheless he is a puzzle. The visitor's first impression of the loquacious, ceremonious coloured folk of Kingston, who grotesquely mouth the apology for English that is all that has been left to a race taught to forget its own African gibberish, will not in all probability be favourable. Yet some of the domestic servants are cheery, good-natured and willing, and this modified fealty is surprising in view of the abolition of slavery and the immense preponderance of the coloured population. In all probability the finest of the negroes were the brave but ill-starred Maroons, and who knows but, better handled by some of the old-time Governors, they might have made a law-abiding community and furnished admirable recruits for the police? Tactless treatment and the fatal national policy of underestimating the enemy's strength gave them many an easy victory over the regular troops, for even the 
Fighting Fifth can be demoralised by exhaustion. By leaving their outposts undefended and luring the regulars into ambush, they whipped them badly, and in the end surrendered not to men at all, but to dogs, bloodhounds imported from Cuba for their suppression. Such wholesome fear had they of these brutes that one condition of their surrender was that a line of troops should always be placed between them and the hounds. Many were deported to Nova Scotia, where they died of the cold; others to Sierra Leone, where they failed to pick up the lost threads of their forgotten ancestry raided by Drake and Hawkins in the brave old times of the slave trade.

The worst feature about the Jamaica nigger is his verbosity. He must talk, and his pompous phrases and queer mistakes, his self-consciousness and passion for argument make him a very perfect nuisance. His capacity for silly chatter is amazing, and, like the great overgrown child he is, he can bare his teeth in loud guffaws over the most silly jokes. On Sunday afternoon, issuing forth with his fellows from some little tabernacle, the floodgates of his theological lore are opened with terrific results. I have heard a crowd of them gravely arguing whether precedence should be accorded to His Majesty King Edward, the Archbishop of Jamaica, or the Pope of Rome. His Majesty won in a canter, and the Archbishop was runner up, his Holiness of Rome having few supporters among the congregation of the little Bethel on the hill. The cabmen of Kingston are an importunate gang and very rough in most cases with their animals. By way of contrast, I recall a coachman out at 


\section{FLORIDA AND THE WEST INDIES 203}

Moneague, who wore a decoration of the R.S.P.C.A., which, I soon had opportunities of seeing, was richly deserved, and who proved, on the long drives to outlying pens, a most entertaining and civil companion.

After a month of hustle, rough fare and Cuban extortion in succession, the restful balconies, cool billiard-rooms and admirable cuisine of the Jamaica Club were Paradise Regained. Kingston itself, a business centre and port of entry rather than a pleasure resort, has several adequate hotels, the Myrtle Bank for convenience, the Constant Springs for beauty of surroundings ; but personally I was, on the recommendation of Captain Constantine, so fortunate as to be admitted to the Club, and there I spent some very pleasant days and nights. The table was excellent. There was a dish of black crab that made old men young and sick men whole. (At one season of the year I believe that it makes young men old and whole men sick, but that was not at the time of my visit.) There was a cocktail that filled the heart with charity. There were cool verandahs in which to drink your morning tea, and quick, quiet servants to look after your wants. Mankind is divided into two categories, club men and the other kind, and club men, I imagine, are never so comfortable as in clubs.

After American cities and Havana, everything in Kingston seems absurdly cheap. In the matter of cab-fares, for instance, there was a descending scale from five dollars for any short distance in New York to a "quarter" (Is. $\frac{1}{2}$ d.) any distance in Havana, and to sixpence any distance in Kingston. Nay, the Kingston cabman will, as a rule, if traded 
with at the starting-point, take you a short distance for a "car-fare," i.e. threepence, surely the cheapest cab-fare in the world.

But if Kingston offers little to detain the tourist, there are many beautiful spots with ideal climate in the island, which, not much more than a tenth of the area of Cuba, is far more beautiful, an island of mountains and of roads, thousands of feet of mountains, thousands of miles of roads ; an island of palm, tree-fern, banana, sugar-cane, pimento, mighty cotton-trees studded with orchids, brilliant flowers and beautiful birds. The climate is heavenly in spring-time. Even in Kingston, by no means its coolest town, the mean temperature lies between 70 degrees and 90 degrees, and up in the hills at Moneague or Mandeville there is perfection for twelve months of the year.

The Moneague, a village which lies some miles beyond the railway terminus at Ewarton, is a most attractive resort, and has one of the best hotels on the island. The afternoon train goes by way of Spanish Town, and from Ewarton there is a drive of a couple of hours over hilly roads that give magnificent mountain views. St Ann has been described as the "Garden of Jamaica," and certainly it is a beautiful parish. The early mornings are gorgeous, and there was a short drive out to a deep waterhole, belonging to $\mathrm{Mr}$ Roper, in which we took a delicious plunge, frightening the little "tikki-tikkis" that swam in the shallows, and causing no little amusement to a party of grinning little piccaninnies assembled on the hill opposite. Then there was polo at Orange Hall. The Roper family can put a four in the field, and "hot stuff" at that, 


\section{FLORIDA AND THE WEST INDIES 205}

and the pace is fast and the shooting often good. If the riding looks a trifle reckless to the visitor, it must be remembered that these Creoles ride like Centaurs, and are one, body and mind, with their mounts.

While in St Ann I visited more than one pen, for there are men of Devon in the parish, and I had known some of the pen-keepers in the old country. One of the prettiest little pens was Cedar Valley, which commands a view of the sea and a fine panorama of surrounding country. Mr Conran's larger residence in his adjoining pen was also, I noticed, on a hill. This site combines, I imagine, the advantage of dryness with a more sweeping view of the estate, an important consideration in a land in which petty theft is a commonplace.

The Garden of Jamaica was all at its best in June. That the island is, with the solitary exception of Dominica, the gem of the Antillean tiara is generally admitted. Compared with its equally fertile neighbour, nearly nine times its area, that lies a hundred miles further north, it is as Devonshire to Suffolk, with glorious mountains that plant their feet at the doors of the capital and in the spume of the sea, whereas from most standpoints in Cuba the distant vista of the hills is suggestive only, like the faint blue on the chin of its priests.

St Ann is the cattle parish. Sugar may flourish more generously in Westmoreland, but sugar is a fluky friend, and the prosperity of Jamaica's future rests on other foundations. At present, Jamaica sugar is most appreciated in the form of rum, and the cane is supplanted by the banana in the vegetable assets of the island. Down the winding 
gradients of the parapet-guarded road from Moneague to Ewarton come groups of stalwart blacks of either sex, all clad in many hues, some grinning, others dour, swinging along with the rhythmic gait of their kind, the basket of fruit balanced on each woolly skull, the empty hands thrown out to balance their swaying bodies. Over the beautiful valley, down there on my right, the evening mists roll like a thunderous sea too distant to reach the ear. The views of peaks and depths are magnificent, and the vegetation runs riot, broken only by the picturesque interruption of thatched villages or long perspectives. The Devonians who have settled in this lovely part of the island, looking through their ever-open windows on good red earth and lush pastures, can, with little effort of the imagination, picture themselves back home in their fairyland between the Channels. Seeing that communication with Kingston and the outer world generally is wholly by road and rail, a laborious pilgrimage not repeated more frequently than is essential, these cattle-pens, which cover anything from five hundred to five thousand acres, are wonderfully self-contained. Indian, Hereford, Texas and other cattle are the chief interest of the pen-keepers, and the beasts fatten wonderfully on guinea and para grass. The great drawback of the pastures is the frightful abundance of ticks, three or four kinds of them, which ruin the animals and bring misery to those who have charge of them. Several plans have been mooted for ridding the cattle districts of these pests. Some hold the belief that Cuban penkeepers have solved the difficulty by firing the 
grass, but on the other hand, I was told most emphatically by a lady, whose husband breeds cattle on a large scale in the Santa Cruz district, not far from Santiago, that ticks are as abundant there as ever they were, and that they are now, as always, the ruin of both horses and cattle.

The cattle on these pens, though of the first importance, do not monopolise the owner's capital and attention to the entire exclusion of agriculture, for a few thoroughbreds are raised, and pimento is grown and dried on barbecues for the market. During my stay there was a meeting of pimentogrowers, at which, I believe, something was done in the way of fixing the price of a product notoriously subject to artificial fluctuations. Pimento, better known as allspice, is grown for the European market practically nowhere else in the world, though Mexico and one or two other countries in those latitudes produce small quantities of inferior grade. Spices, however, are a poor source of wealth in these days, and even with this monopoly the island cannot reckon on any serious revenue from this vegetable. Tea of moderate quality is grown in the island, and Blue Mountain coffee of such exquisite aroma that the whole is exported, bought up in advance each season, and you cannot taste a cup of it in Jamaica. Sugar, cocoa, tobacco are all grown in the larger pens, if only in small quantities for home consumption, for there are few plants in the tropical catalogue that the sun and soil of Jamaica will not conspire to produce. The life of the pen-keeper is the ideal one for young men who care nothing for the artificial luxury of great cities and revolt from the office-desk. It is 
a clean life in the open air, sun-baked, healthful; not indeed offering a short-cut to fortune, for the island is not perhaps in the heyday of its prosperity, and every deal in live stock is a gamble, but holding out wholesome occupation for mind and body and a competence for those who, while unwilling to rush in, yet do not fear to tread.

For the naturalist, with Gosse for guide, philosopher and friend, the interior of Jamaica is a valley of delight. Of mammals there is nothing more interesting, if also more detested, than the Mungoose (Herpestes), introduced five-and-thirty years ago by Espeut, a planter, who thought that it might rid the island of the cane-rat (Mus saccharivorus). Espeut proposed, and the rat disposed, to such good purpose that it and the mungoose have since played "Box and Cox"; in other words, with the cunning of its race, the rat altered its habits to suit the situation, took to the trees and ventured forth only at night, whereas the mungoose, lacking such adaptiveness, still lives in ruined walls and hollow rocks, and is active only during the day. Encounters are therefore rare, and the mungoose has slaked its appetite on domestic poultry, native ground-game and snakes, most of which were beautiful and harmless. Hence the ruin consequent of this ill-advised introduction, to cope with which the hated mungoose, though hunted with dogs, shot down, trapped, poisoned, smoked out of its lairs, and done to death in any and every way, still holds its own. Truly, "the evil that men do lives after them." Espeut acted in all good faith, and may he sleep in peace! but his interference with the affairs of Nature has made a 


\section{FLORIDA AND THE WEST INDIES 209}

rare pother in the distressed island. Nor are all the effects of this vermin's bad deeds so direct as the destruction of chickens, quail, ground-doves and guinea-fowl. Thanks to the disappearance of these and lizards by its agency, ticks, the stock-keeper's greatest curse, have increased to an alarming extent. Although the mungoose is far too prosperous and plentiful for the good of the pen-keeper, it is a mistake to think, as some writers irresponsibly suggest, that numbers are in evidence everywhere like sparrows in a London square. Like all rapacious animals it is secretive, though not, as already stated, nocturnal in its habits. During a couple of weeks, spent in various parts of the island, I saw only one, and that ran across the road just in front of the buggy in which I was driving back from a morning dip at "Doctor's Cave," Montego Bay.

Those who have wandered off the track in other tropical islands, who have known hot and solitary hours in Java and Ceylon, will instinctively scan the tree-tops of Jamaica for signs of monkeys, but in vain, for these merry folk are not among the forest creatures. Whether, previous to extermination by the Spaniards, they ever peopled these glades is an open question, on which we have no evidence of value. An attempt has been made to connect the name "Moneague" with their occurrence, but the more likely etymology of the word suggests reference to the mountains and water of that favoured district.

If the quadrupeds of Jamaica are few and insignificant, its birds are so abundant, varied, beautiful and interesting as to repay a closer study 
than has been made of them and their ways. Long-tailed humming-birds (AEthurus polytmus) quiver like living gems beneath the towering banana leaf or over the flaming hibiscus; green parrakeets (Conurus nanus) dash and scream on the edge of the jungle beside the road; the black sparrow (Loxigilla) peeps curiously from the top of a bush, and for an instant displays the coquettish riband of scarlet at his throat. My old friend, the turkey-buzzard, is conspicuous in all the cities, where he goes by the new name of "John Crow," though he smells no sweeter than elsewhere. He is supposed to foretell death, a superstition shared by folk of all colours. This is true to the extent that if the pen-keeper sees a calf in a lively condition, with an old "John Crow" keeping watch near by, the calf will almost certainly be dead by night. Of other birds of prey, I saw two round Moneague; the larger is the whistling chicken-hawk (Buteo), a true buzzard, which "John Crow" is not, for all his American name, and the smaller is the pigeonhawk (Falco columbarius), which agrees in size with our merlin. Both are freely shot by the penkeepers, and trophies of their claws and wings may often be seen hanging in the porch. Some of the niggers eat the chicken-hawk. A boy at Montego Bay told me that they catch the bird by taking advantage of the fierce way in which it digs its talons into its victim. A dead chicken is exposed in a hollow gourd tethered in the middle of a compound, and one or two lads lie in ambush with cudgels. Presently the well-known whistle overhead causes them to grip their staves more tightly, and down comes the great hawk, pitching on the 


\section{FLORIDA AND THE WEST INDIES 2 II}

bait, and taking so firm a grip with its claws that it is easily beaten to death before it can disengage itself. I asked my informant whether he also ate "John Crow," but he replied, with evident disgust, that the bird, being a carrion-eater, would not be fit for food, and I was reminded of the touching story of Federigo's falcon in Boccacio.

In the country districts, and particularly in the rich pasture-lands of St Ann, no fowl are more conspicuous than the blackbird (Crotophaga) and ting-ting (Quiscalus crassirostris), the former a cousin of the cuckoos, the latter related to our starling. To the stock-owner they render the same service, ridding his horses and cattle of ticks, and may be seen in company, hopping in front of the beasts, and picking ticks off their muzzle before the pests have taken firm hold. The blackbird has a very powerful bill, but that of the ting-ting is slender and pointed, like the starling's. Now and then they seem to dig viciously at the nose of some heifer or mare, but the impression is evidently erroneous, for the grateful animals never offer the least resistance, or display any sign of nervousness. Ticks are a serious problem in Jamaica. They were a serious problem to myself on one occasion when I inadvertently wandered in loose continuations through some guinea-grass. Forty or so attached themselves to my limbs, and took the best part of an hour to remove. Some penkeepers, apparently forgetting the harm done by Espeut and his mungoose, favour introducing the real starling, thereby to increase the bird brigade for the suppression of these creatures. Others are hostile to any further acclimatisation of exotic 
allies, and prefer to wage indirect war on the tick population by fighting the mungoose and thus encouraging the restoration of native birds and reptiles. The whole of Jamaica's economic zoology is, it will be seen, in a House-that-Jack-built muddle, and to get the house once more in order will need clear heads and open purses.

Another most interesting small bird with which (alas! out of season) I made friends was the "September," or petchary (Pitangus caudifasciatus), toothsome table-bird in the month from which he takes his name, but in spring-time merely an object of interest to the zoologist. $\mathrm{He}$ is one of the family of tyrant-birds, and he justifies the relationship by boldly attacking any other bird, even of the size of the "John Crow," that may venture too near his nest. More than once I watched that unwieldy vulture in headlong flight before a bird that looks no bigger than our lark, and this little drama of the air suggested to me that, although we regard the vulture as a carrionscavenger only, the petchary probably knows that it will raid a nest and eat the young when occasion offers. The spectacle of a small bird putting heavier fowl to flight can be witnessed at home without going all the way to Jamaica, for I have seen the swallow chase the owl, the robin chase the magpie, the skua chase the gull, and the gull chase the gannet. Indeed it almost looks in every case as if the consciousness of guilt robbed the stronger of its strength and put Goliath once again at the mercy of David.

The "Tom Fool" (Myiarchus validus), a common bird in the Moneague district, owes its 


\section{FLORIDA AND THE WEST INDIES 213}

singular name to the indifference with which it sits on a rail while little nigger boys throw stones in its direction. Having watched some of their marksmanship on these occasions, having seen their stones fly wide of the bird until at length it seemed bored and flew away, I suspect that its foolishness is more apparent than real, as its safest defence is to keep still. Its very beautiful nest, which I know only in drawings, is, I understand, attached to the lower side of a thin twig high above the ground, and in neither architecture nor position can it be regarded as the work of a fool.

The only other bird that I remember noticing is the mosquito-hawk (Chordeiles), a graceful kind of night-jar, several of which skimmed close to the spot from which I watched the polo at Orange Hall.

As most of the snakes have been destroyed by the mungoose, the reptiles of Jamaica consist chiefly of lizards on land and turtles in the sea. Of lizards there is some variety, but the only two that I encountered were the "Croaker" (Aristelliger prasignis), a gecko, which I heard, and a houselizard with a red protuberance at the throat, of which I did not learn the name. The croaker utters a dismal, haunting note, which Creoles accept as a forecast of rain. One evening, after dinner with the polo team, I sat in a hillside verandah watching the effect of a pale young moon robbing the fireflies of their lustre. Croakers croaked from the dark places, and, mindful of the ten-mile drive that lay before me in Mr Roper's open buggy drawn by two sporting mules, I looked up at the blazing Southern starlight for comfort. I 
need not have felt anxious. That night, and seven nights more, no rain fell, and I shall henceforth rank this ingenious but misinformed reptile with the newspaper weather prophets. The other lizard, which was to be seen in the verandahs of the Moneague Hotel, displayed a curious little crimson swelling at the throat suggestive of the bursting of a small blood-vessel. Perceiving that this was exhibited by volition, I at first set it down as an expression of fear or anger. Then I took note that this singular badge was not always worn on my near approach, so I sought some other explanation. Might it perchance be a secondary sexual character, a red necktie worn by the male to attract the female? This comparison with the weaknesses of my own kind was in its turn rejected when I found that all the lizards of that species wore the red necktie, and these would hardly be all males. Finally, though without any evidence, I decided that it might be a bait for flies, which, mistaking it for a red blossom, of which there are many in that flowery district, would perhaps alight for an instant, only to be snatched up by the owner's lightning tongue. In all probability, each of my theories is wrong: in any case, one only can be right; but half the pleasure of watching wild creatures would be lost if we were debarred from such harmless hypotheses.

The turtles exported from Jamaica to England are for the most part caught on the Mosquito Coast and among the Cayman Islands. The fishermen are very skilful in locating their movements under water of considerable depth with the aid of a water-telescope and in capturing them in a kind of 


\section{FLORIDA AND THE WEST INDIES 215}

cast net. The reptiles are stored alive in kraals, or " crawls," at Kingston and other ports, and are fed on grass. This herbage grows on the shore opposite Kingston harbour and is fetched over at a cost of a shilling a boat-load. The green turtle alone goes to England. I used to watch a number of these turtle in a crawl near the garden of the Myrtle Bank Hotel, and the green turtle was invariably easier to handle than either the hawksbill or loggerhead, both of which struggled and bit savagely. They are taken from the crawl to the liners in small boats. All the liners take cargoes, but they probably do best by the warmer, though longer, route followed by the Royal Mail Company. On the Tagus we shipped over a hundred and got the bulk of them alive to Southampton. Some of them were the cause of a rather amusing episode. In the adjoining deck-room to my own was an invalid, with the ship's doctor in close attendance. I told her that if she should want him in the night, she had only to knock at the wall, as I am a light sleeper. Sure enough, at two in the morning came the summons. Tap! tap!-then again. In a twinkling I was out, and then the tapping came again, this time from overhead. I listened at the patient's door and heard no sound. So I went back to bed. And well it was that I did not fetch the doctor from his cabin, for the invalid had slept soundly through the night, and the tapping came from the flipper of a turtle lying on its back on the spar-deck overhead.

Those who wish to give their stay-at-home friends a taste of turtle-soup without the trouble and expense of taking home a live one will find a 
very palatable substitute in the turtle-tablets sold in Kingston by Messrs Sherlock and Levien and other makers. These aré made up in boxes of a dozen, costing as many shillings, and very excellent they were voted on my return.

Another invertebrate luxury of the connoisseur in Jamaica is the black crab (Gecarcinus ruricola), no dweller in the sea, like so many of his family, but a land-crab that lives in the hills. When in season, as it was at the time of my visit, it is delicious; as served at the Jamaica Club, it is not to be praised with ordinary words. It may be that the new American spelling may give us some adequate tribute to its delights. I believe that a black crab, a calipeva and a ringtail pigeon are to the epicure of Kingston what the diamond-back terrapin, canvas-back duck and glass of iced water are to the gourmet of New York, but the second and third of these were not to be had during my too short stay. Roast parrot is another luxury of the island that I did not taste. This perhaps was as well, as they say that to suck the bones brings madness, and not to suck the bones of a bird said to taste exactly like a partridge would be beyond my powers of repression.

Of spiders and insects I had little or no experience, always excepting the mosquitoes. Of these I had some. One immense spider I saw in a crumbling wall at Montego Bay, a tarantula of some kind, but failed to secure it in one of those not very whole-hearted chases of mine when such grim treasures are the quarry. The most conspicuous insects were those of the darkness, which their little lamps made denser by contrast. There 


\section{FLORIDA AND THE WEST INDIES 217}

were the ordinary fireflies, not, I imagine, very different from those I knew so many summers ago in Florence. Then there were others, known here as the "Jumping Peenie" (Pyrophorus noctilucus), which I also saw in Cuba. This curious little beetle can light and extinguish its vivid little lamps at will, though with what object no one has explained. They are situated near the eyes and are so bright as to be conspicuous even in a well-lighted room. If grasped not too tightly between the thumb and forefinger, this entertaining insect gives a series of convulsive jerks. When laid on its back, it may jump several inches in the air, usually alighting feet first and flying away. It furnishes, in fact, a convenient subject of after-dinner wagers, and large sums may be lost (by those who have large sums and small brains) on the stirring doubt whether it will land on its feet or on its back.

The industries of this beautiful island are so varied, the soil so rich in pasture and crops, the country so well watered and with such excellent communication by land and sea, that the current talk of stagnation in so resourceful a colony is hard indeed to understand. Apathy, on the part of both the State and the individual, mismanagement, absenteeism and similar evils are declared to be at the root of Jamaica's commercial backsliding, at any rate by those who write for the papers without any other stake in the game. I do not propose to point the way to fortune, for I never yet walked a yard of it myself, nor ever shook the pagoda tree to my own profit.

The sugar industry, so long the mainstay of the island, has in part succumbed under successive 
blows of Continental bounties and the great output of its beet substitute, and rum is nowadays as important as the sugar itself. Coffee is another product of some importance, and the best Blue Mountain coffee is all grown for export and cannot be bought in the island.

By far the most important trade to-day is the export of bananas to Europe and America, and in this growing enterprise much American capital is profitably invested, for the United Fruit Company, in conjunction with Messrs Elder Dempster, control almost the whole of the trade. The Americans have come in for hard words from those Creoles who, seemingly unable to secure the trade for themselves, resent the enterprise of the interloper from Boston. Yet the market is an open one; the Yankees are not there for their health, and they do not appear disturbed by their reception. The criticism more directly aimed at the diversion of the subsidy paid in connection with the direct mail contract to put Costa Rica bananas on the home market to the detriment of Jamaica-grown fruit is less easily met. The Costa Rica banana gives quantity rather than quality, and the working class, the chief consumers of the fruit in both hemispheres, likes plenty for the money. In any case the position is an unsatisfactory one, and it is surmised that the Government will decline to renew the subsidy when it expires.

Cattle-farming is still in the hands of the English, and, as has been said, the pen-keepers have some other interests to engage their attention and employ their capital. What may be the industrial future of the island is at present doubtful, 
but I shall be surprised if the tourist be not an important factor in its future prosperity.

Of the few seaside towns that I visited, Montego Bay was in some respects the most delightful, and the sea-bathing, at a spot called "Doctor's Cave," must certainly rank among the finest in all the world. The water is so clear that you can see a threepenny-piece lying on the sand in three fathoms. The sand is so soft that it rubs the skin as fine as silk. There is deep water, with a raft, for those who dive ; there is shallow water, with a firm sandy bottom, for those who only paddle. There is a bath-house, with dressing-rooms and a fresh shower. If anything, the temperature of the water before breakfast, when $\mathrm{Mr}$ Hart (not to know Mr Hart at Montego Bay is not merely to argue yourself unknown, but also to risk losing a mass of local information) used most kindly to drive me over in his buggy, was a trifle too warm to refresh. Curiously enough, perhaps by contrast with the then warmer atmosphere, it struck colder at midday. In all my memories of bathing in fresh and salt, from April shivering on the shore of the Baltic to July basking in the Mediterranean, morning dips in Sydney Harbour, at Funchal, up the Thames and down the Channel, "Doctor's Cave" will henceforth have a corner of its own. I never knew its better from Tasmania to the Tweed. The railway journey to Montego Bay from Kingston lasts six or seven hours, and the track winds through some of the loveliest mountain scenery in the island, differing from that through which I rode in Carolina a month earlier in the tropical vegetation that clothed the foothills, giving way to a more Northern type of vegetation as the colder 
summits were reached. The route lies near the curious "Cockpit Country," a rocky, rainless district, all white limestone and desolation, suggesting reefs of dead coral flung up from the bed of the Caribbean and planted miles from the coast.

Montego Bay itself is a pretty little town without, perhaps, many resources for the tourist who has none of his own, but affording the aforementioned capital bathing and very fair sea-fishing in the bay, close to the moorings of the ships. Just opposite the town lie the Bogue Islands, which enclose an almost endless labyrinth of smooth lagoons and sheltered channels, in great favour with boating parties with private reasons for avoiding the more open sea. It is, however, advisable, at any rate for the tenderfoot, not to row too close to these islands, for mosquitoes swarm among the mangroves as thick as oysters and are quick to alight on those who trespass too near their homes. There is no quay accommodation alongside, and small boats are requisitioned for embarking both passengers and fruit for the vessels chartered by the United Fruit Company, which has here an active centre of its trade in the island.

It is not unusual to find barracouta of large size lurking under these vessels at their anchorage off the town. The barracouta (Sphyrana) has this habit of lying in ambush under vessels and piers and dashing out on any small fish that pass its hiding-place. Rightly or otherwise, it enjoys a bad reputation among bathers, and I was told of one which for some weeks hung about the ladies' bathing-place at Barbados, causing much uneasiness. With a water-telescope (nothing but a wooden box with one side of glass) borrowed from a Caymah 


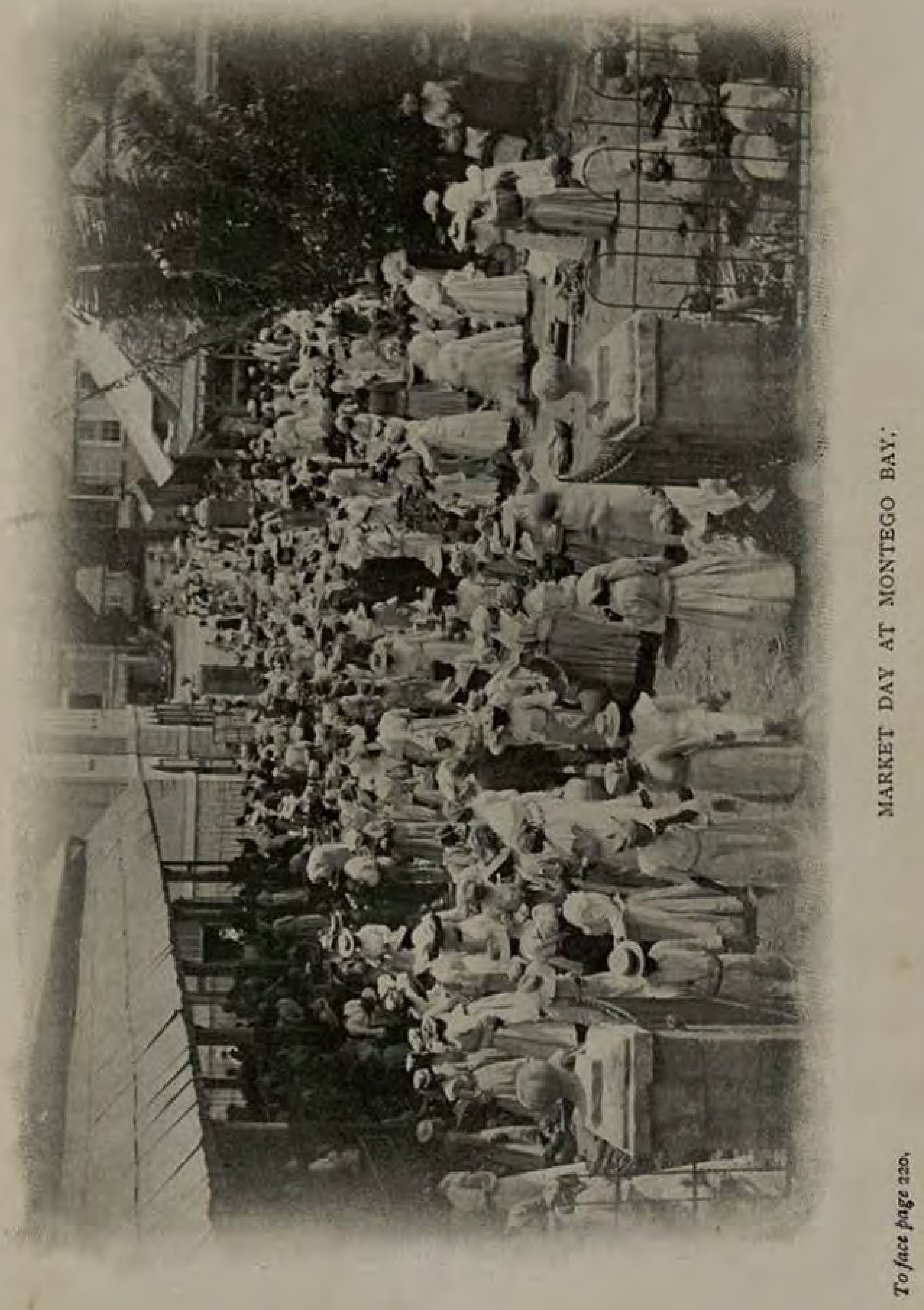


Island turtle schooner lying in the bay, I managed to locate and catch a small barracouta lying under the vessel, the bait being a "piper," i.e. the garfish with the long upper jaw (Belone). The Piper was caught from the boat by a coloured boy named "Dickie," tout court, who owns a couple of handy small boats and knows all that need be remembered about the local fishing. A dollar or two spent with "Dickie," is an education in small fishing, and I gladly took it at the price. In order to catch the bait, no easy matter, he used a single small hook at the end of a very long line of sewingcotton (perhaps No. 40, if I dare guess at it), and baited it with a fragment of dry bread. Less than a yard above the hook was a tiny cork to serve as a float. How he managed, on a day without a breath of wind to stir the glassy surface of the bay, to fling the hook at least thirty yards, or how, after letting it drift with the tide at least another thirty, he contrived to see the least movement of so small a tell-tale, I do not pretend to say. I merely record the fact that he did both, and, as the result, was not many minutes before he hauled in a fine piper. This was hooked through the tail on a stout line with a large hook and no lead, and the lure was then paid out until it swam in front of the dark form lurking under the keel in perhaps six or eight fathoms. It did not dangle long before there was a rush and a tightening of the line. On a rod the barracouta would have given good sport, but I do not know that it would be possible to use a rod while bending over to control the movements of the bait with the aid of the water-telescope, which floats on the surface. Few large fish can resist any 
of the garfish family on a hook. One evening I trolled with one among the Bogue Islands, along a gloomy channel that grew depressing in the sinking sun, and something grisly, perchance a tarpon, rushed away with the half of my tackle. There is, for those who like such forays with an old trout-rod and single gut tackle, plenty of fun to be had with the smaller fishes of the bay, yellowtail, breams and butterfish, variety enough to stock an aquarium or make a "fry," but not, of course, affording much excitement. I was also much interested in boarding, under "Dickie's" guidance, one of the Cayman Island schooners and inspecting the ingenious castnet arrangement in which the turtle are captured. The crew, dear unsophisticated islanders! who paid me the compliment of taking me for an American, and begged me to ask $\mathrm{Mr}$ Roosevelt to annex them, had that morning caught an immense hawksbill turtle, which they were quite anxious to sell me for thirty shillings, including the removal of the flesh from the shell, the valuable part, so I understood, of the bargain. I managed to decline their offer without giving offence and took leave of them. They had two of their ladies on board, quaint, unexciting females, who do the cooking and make themselves at home during the voyage.

One of the best table-fish in those waters is caught in deep water on handlines carrying many hooks, like those employed for the hideous spada of Madeira. It is called the silk-fish, and justifies that favourite American saying, "fine as silk," which is current, by the way, in Cornwall.

One of these days, if anyone has the enterprise to build a good hotel there and appoint "Dickie" 
sea-fisherman-in-ordinary, Montego Bay should prove a very serious rival of Port Antonio with the tourist element, but I hope that its mosquitoes may be dealt with first, else these will prove a blot on its escutcheon.

These insects, together with the hyperæmia induced by much rum and little exercise, tinge the complexion and enrich the vocabulary of those who dwell in the tropics. From the earliest times the mosquito has been known for one of the fiercest of our winged enemies, those in the Dore drawings for the Inferno not excepted, and of late years it has acquired new significance as an admitted vehicle of disease germs. As a matter of fact, the association between certain mosquitoes of the plains and the disease known as malarial fever is not quite the novelty that some people imagine, for there are African tribes who have for generations recognised the connection. For the practical purposes of medical science, however, the two kinds of mosquito known as Anopheles and Stegomyia were made known to the world as the chosen airships of the germs of malaria and yellow fever respectively by the researches of Sir Patrick Manson, Professor Grassi, Major Ronald Ross and other workers, and in America much work has been done by Colonel Gorgas, now in charge of the sanitation work at Panama. The common Culex, one of the most familiar mosquitoes of the tropical bedroom, conveys, so far as we know at present, no disease, being detestable only on account of its maddening midnight music and no less irritating bite.

When I arrived at Montego Bay and first admired the snug little town from my lodgings on 
the hill, I had no presentiment that my education in the malice of mosquitoes was to be (as I hope) completed there. I thought I knew something of these insects elsewhere, on the far northern shores of the Baltic, in the comfortable verandahs of Java and Ceylon, on the promenade deck of a steamer anchored for a summer fortnight in a Queensland estuary, and in the dreamy garden of a little residence on the outskirts of Morocco City. Even my large and airy apartment in the hotel at Havana had contributed a very little to my knowledge. But in the short space of a week, Montego Bay surpassed them all. As a matter of fact, I stayed there during an exceptionally bad week, the second in June, immediately after heavy rains, which always wash the mosquito from its hammock on the stalks of the guinea-grass and brace it for further villainy. It happened therefore that the Montego Bay mosquitoes turned out to welcome me in such force that one morning I counted no fewer than one hundred and sixty-two of them clinging to the walls of my room, including both Culex and Anopheles (sixty of the latter). This total doubtless excluded a number in inaccessible parts of the wall, which I did not investigate, as well as a few that had managed to get within my ramparts, inflict their maddening bites on my ankles and then die the death on the curtains. In all, therefore, two hundred would probably be no exaggeration. I went down to breakfast with swollen ankles and tingling wrists, but of course got no sympathy. Creoles take no notice of these domestic nightingales and chuckle over the newcomer's misery, just as equally sympathetic folk at home shake their sides 


\section{FLORIDA AND THE WEST INDIES 225}

over chilblains and sea-sickness. Immunes make little of these troubles with a brutality all their own. It is true that a year of probation brings freemasonry and indifference henceforth to the insects, but of what consolation is this to birds of passage? In view, on the other hand, of the importance of the tourist, American as well as English, in the future welfare of Jamaica, it would be gratifying if some of the medical men on the island specially interested in the group- $\mathrm{Dr}$ Grabham, of Kingston, son of the well-known authority on the spiders of Madeira, and Dr M 'Catty of Montego Bay are among their number-could devise some means of either prevention or cure. $\mathrm{Up}_{\mathrm{p}}$ to the present, apart from the serious work done in the suppression of the more dangerous kinds, the simple question of dealing with mosquito bites has been strangely neglected. As regards prevention, the only method that I have seen practised with success is the effectual screening of dwellings, the best example of which I saw at the Ancon Hospital, Panama, though some of the small black mosquitoes seem able to penetrate within the finest netting. Still, the larger villains are excluded, which is something gained. The hotel that I dream of for Montego Bay should be screened throughout, not the windows only, but even the outside verandahs, with double doors. So only would life be endurable if the insects are often as active as I knew them there. Natives of the island do not even bother with curtains for their beds, but the hotels are for such as want their stay to be both short and merry, and have neither the time nor the inclination for gradual acclimatisation. 
Quinine, an admirable preventive of malaria, of which I took from six to eight grains daily for five or six weeks, and with the best results, does nothing to allay the misery occasioned by the bites, and I was a mass of wounds, the half of them selfinflicted, for, against all counsels of perfection, I scratched myself until my ankles were raw and on the verge of blood-poisoning. By day I tore myself with intent, by night without, for whenever I woke up I remember that my nails were busy. I am not of the stuff that made martyrs at the stake; God and my dentist know that I am a woeful coward in the matter of physical pain, and to keep my hands off such irritation is beyond me. Where the mosquitoes leave off, I begin, and the result is appalling. One of my most agonising experiences of these residents at Montego Bay was one evening when playing lawn-tennis in a gentleman's garden that gives a wonderful view of the Bogue Islands and shipping in the bay. Even a bonfire of pimento leaf, which is regarded as efficacious, failed to keep the swarms off the courts, and I enjoyed the novel sensation of feeling a couple at work on my eyelids at the moment of serving or taking a half-volley.

It is true that the orthodox tourist season is not supposed to last beyond the end of April, but there is no other reason than the mosquitoes why-at any rate for those who do not mind moderate heat and wear light clothing, best bought in the island-it should not be prolonged a couple of months.

It is time therefore that something should be done to cope with what must undoubtedly be regarded as a serious drawback to any tropical 
tourist resort. The so-called remedies are futile, with the possible exception of the fresh juice of a lime diluted with a little water, and applied to the bites at once. Carbolised vaseline and witch-hazel (Hamamelis) fail utterly to bring relief, and as for the strong essential oils of clove and lavender, in praise of which so much has been written (by those who sell them), I venture to say, after having tried them in Africa and Australia, that mosquitoes like them rather than otherwise, regarding them much as a teetotaller regards a dash of Angostura bitters in a beaker of ginger-beer. Well, I take my leave of the mosquitoes of Jamaica, which amount in all to twenty or thirty different kinds, which multiply after their accursed kind in drains, swamps, cesspools, crab-holes, the depressions made by the feet of cattle walking over mud, and other nurseries suited to such gentry. Malaria, yellow fever, elephantiasis and bloodworms are among the boons they bring to mankind. Only the female sings and bites. The male is a silent fellow, who keeps himself to himself and lives on a simple vegetable diet. There are medical men who vow that, of Stegomyia at any rate, the male also is a bloodsucker, but there are more who doubt it.

From Montego Bay to Port Antonio I coasted on the Baker, chartered by the United Fruit Company. With us travelled about 10,000 bunches of green and golden bananas, to which we added another 10,000 at Ora Cabessa and Port Maria. At Montego Bay the fruit came alongside in long boats, one of which I managed to photograph from above, each carrying three or four hundred bunches. Black lady-greengrocers, retailing fruit for the 
ship's crew, chaffered on board until bundled over the side with more force than ceremony just as the anchors came up, and we got under weigh just as the sun was going down astern. The north coast of Jamaica is described by a local enthusiast as "impressive in its grandeur." I am quite sure that it is so, only, having passed in the night, I am obliged to take its grandeur on trust. The run was made pleasant by the good-fellowship of the Assistant Manager of the Company, as well as of Captain Oertel, who entertained us after dinner with a splendid gramaphone that gave Melba and Caruso records. There was a German touch about this al fresco concert that brought back my old university days at Rostock. Where is the English skipper of a coasting tramp who would give you selections from Grand Opera, and know all the numbers, music and libretto as well, by heart?

Gradually a little light showed on the top of the cliffs, but it was not until the anchors had rattled down through the clear water inside Port Antonio that I saw the dawn break, gold and purple, over the narrow gates of that beautiful harbour and light up the Titchfield Hotel-its situation is equalled by no other in the island-closed, however, all but a few cottage annexes, for the summer. Thanks to the direct service from New York, this immense hostelry is the resort of American tourists all through the winter months, and apart from this source of revenue, the place has its banana export trade. It is also noted for its rainfall. The hotel is open only half the year; the bananas and the rain go on for ever, and have no seasons. Appropriately enough, I found and left it a lake, on which 


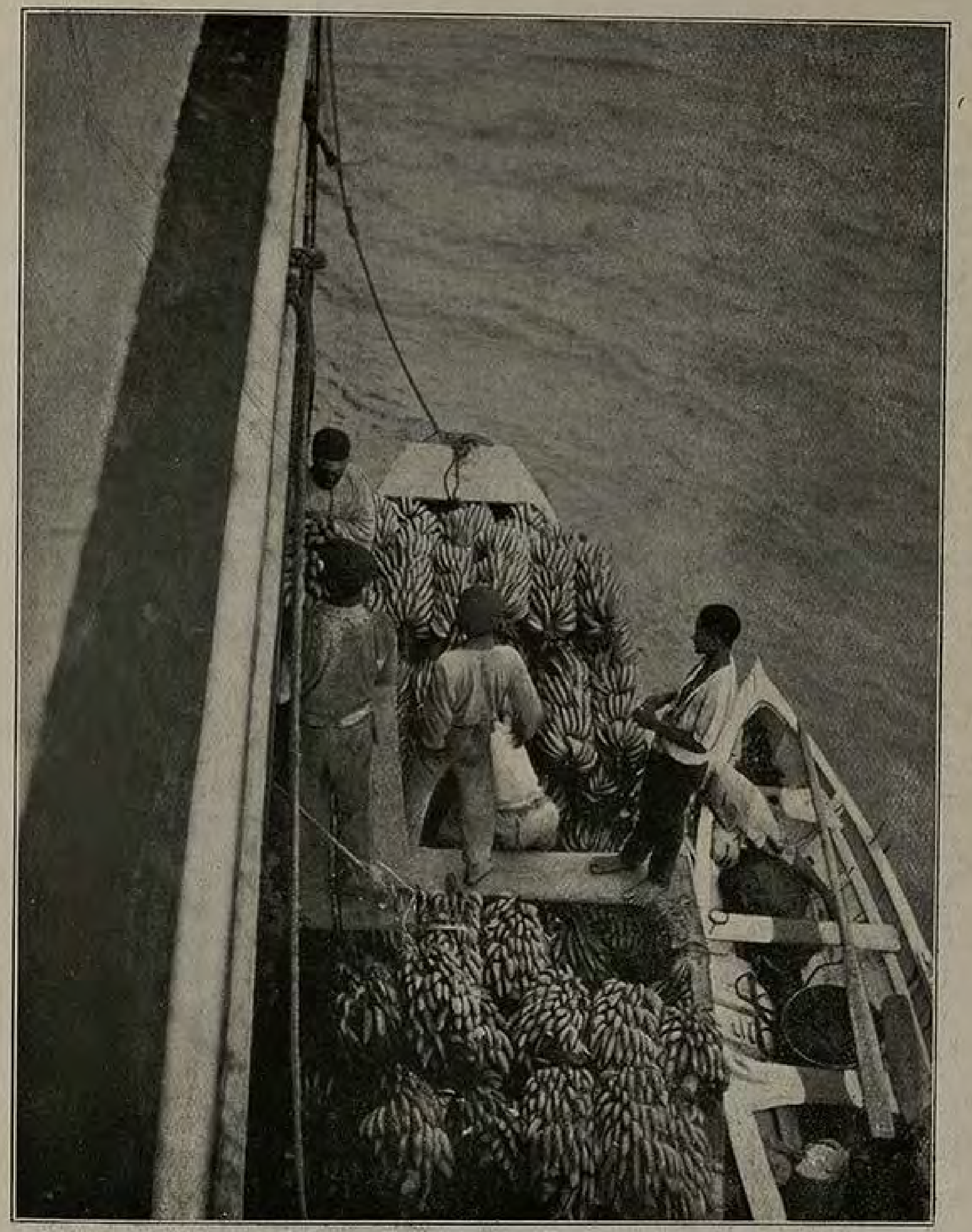

AT THE BIDDING OF THE UNITED FRUIT COMPANY.

To face page 228 . 
gondolas would have moved with more comfort than cabs. The railroad journey back to Kingston skirts the Caribbean for some miles, crossing more picturesque rivers than are to be found on the whole of the rest of the island's tracks. It takes leave of the sea shortly after passing Annotto Bay (so-called, I understand, from the absence of annotto, a vegetable used in the colouring of red cheeses and butters), and plunges once more into the mountains, which it surmounts at the leisurely pace inseparable from such gradients, eventually reaching Kingston by way of Bog Walk and Spanish Town. This completed for me the entire run of Jamaica's railways, and if that mode of travel has its drawbacks in hot weather, there is no other which, in a short time and at small expense, gives so grand a view of the beautiful scenery which, in all the West Indies, I believe Dominica alone pretends to rival.

As a winter tourist resort, Jamaica is only at the beginning of its history, and just as the holiday folk have come to the rescue of many a decaying fishery centre on the coast of England, bringing back a prosperity that had been despaired of, so the island may confidently look to the tourists of two hemispheres to restore the good times that, industrially, appeared to have passed. For its development as a tourist centre there are several important schemes in the air, but the capital is in every case in dollars, not in sterling. This, from one standpoint, is to be regretted; from another, it is of no moment whence the money comes so long as it is not lacking. The winter climate deserves superlatives, and even during rather more than a fortnight in June and July I 


\section{SUNSHINE AND SPORT IN}

had only two days of rain (one at Port Antonio, which should not count) and not one of uncomfortable heat. In the way of amusement for those whose one absorbing recreation is not the quest of health, there is riding and driving and bathing and boating alone to fill a year. Not in all the oceans is there such another island of roads, and England herself, which thinks something of roads, has none finer than her sons have made in that far outpost in the sunset. Americans, fresh from the neighbouring island of Cuba, have told me how struck they were by the contrast. In the remote inland districts the visitor may find better roads, little used and well kept up, than within a mile of Santiago or Havana. Only the cross drains are just at first a source of annoyance to those unaccustomed to drive over such obstacles, but habit soon makes them negligible. For the more energetic horseman there is always a warm welcome on the polo-ground at the weekly meeting, nor is the lazier spectator excluded. There are, in the fall of the year, bald-pates and other native pigeons to test the marksmanship of those who fancy themselves as game shots. There is fishing in both fresh and salt. Of the sea-fishing something has been said. Sport in the rivers takes a little finding out, but there are at any rate three mullet which local anglers hold in high esteem. Of these the finest is the calipeva, and $\mathrm{Mr}$ Bertram told me that he had watched these over the side of his canoe in the Milk River browsing on the green weed on the bed of the river and standing on their heads, so that only the great tails were visible waving in the clear water. The hog-nosed mullet, another fine species, is also caught on rare occasions 
by baiting a small triangle with weed. In this way $\mathrm{Mr}$ Verley, an enthusiastic fisherman well known in the island, once took a brace of very handsome fish at the irrigation dam, close to Spanish Town, weighing $9 \mathrm{lbs}$. and $7 \mathrm{lbs}$. The little mountain mullet, which averages no more than half a pound, will take a silver Devon in broken water, but is more usually caught on either fly, grasshopper, worm on Stewart tackle, or a piece of avogado pear. It never jumps when hooked, but is otherwise regarded, by sportsmen who know both, as no bad substitute for trout. The largest river-fish taken on the rod, bar tarpon in the estuaries, is the snook, which grows to a weight of at least $20 \mathrm{lbs}$. It is taken, generally on live bait, in the Black River, Cabaritta and other waters. For all freshwater fishes in the island a close time, lasting from Ist June to Ist October, is strictly enforced. This prevented my making their acquaintance, and I was therefore disposed to agree with a number of resident sportsmen, who are of opinion that, as fish are many and anglers few, such a long close time is quite unnecessary at present, and that a more useful purpose would be served by a stricter prohibition of the use of traps and dynamite, both of which are much in vogue among coloured poachers.

On the 8th July, the Tagus, sister ship of the Trent, and a crack boat of the Royal Mail line, left Kingston, taking with her myself and alligators, besides some passengers who had come on from New York, and a hundred and twenty turtles to tickle aldermanic palates at home. Most of the accommodation was booked in advance from the Spanish Main, Trinidad and Barbados. The. 
homeward trip was about the most enjoyable I ever shipped on. It started in fine weather, proceeded in fine weather and ended in fine weather, with one afternoon's rain at Savanilla (a pier that would look no better in the weather of Paradise), a second of deluge at Port of Spain, and a third, after leaving Barbados, on which the trade winds moved the steady boat to incipient frolic and several of those on board of her to more than incipient sickness. This fine-weather voyage, with the almost daily distraction during a fortnight of a port of call, lends a charm to the Royal Mail route which is entirely lacking in any more direct. The rest appeal chiefly to those going home on short leave and to other slaves of time. In bidding good-bye to Kingston, I little dreamt of the terrible convulsion that was to make of it a heap of ruins within a few months' time, of the comfortable Jamaica Club levelled with the road, of poor Constantine, who looked after me so kindly during my stay in the island, being among the earthquake's first victims! It was a cruel blow to an island just showing signs of recovery after a long spell of commercial depression, and it is to be hoped that its own energy, aided by the rally of an Empire to its needs, will turn calamity to blessing, and that Kingston, which, for all its quaintness, was a capital of very modest design, may, like so many American cities similarly afflicted, have come through the fire to emerge better than its old self. 


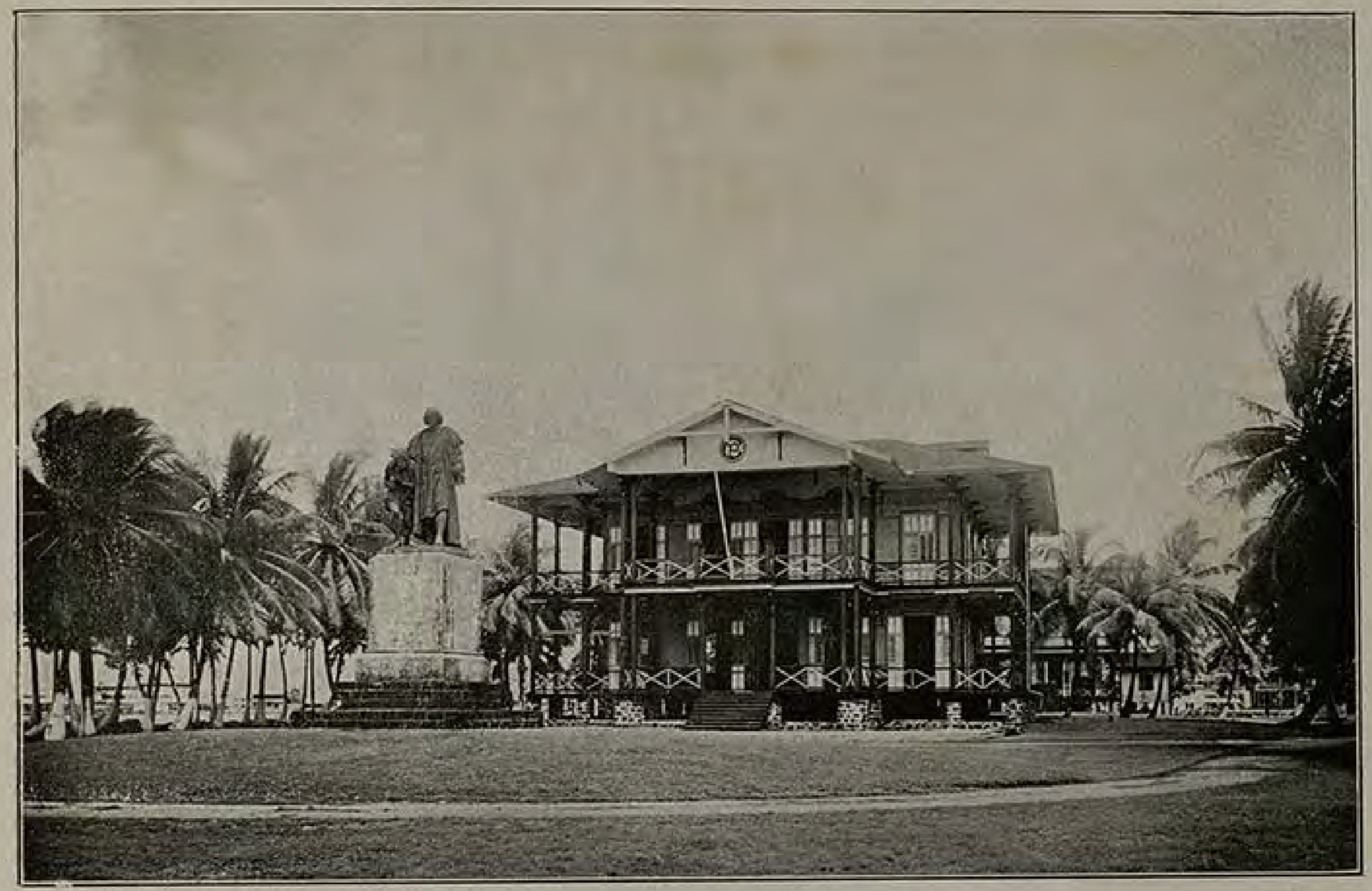

COLUMBUS GUARDS THE HOUSE OF DE LESSEPS.

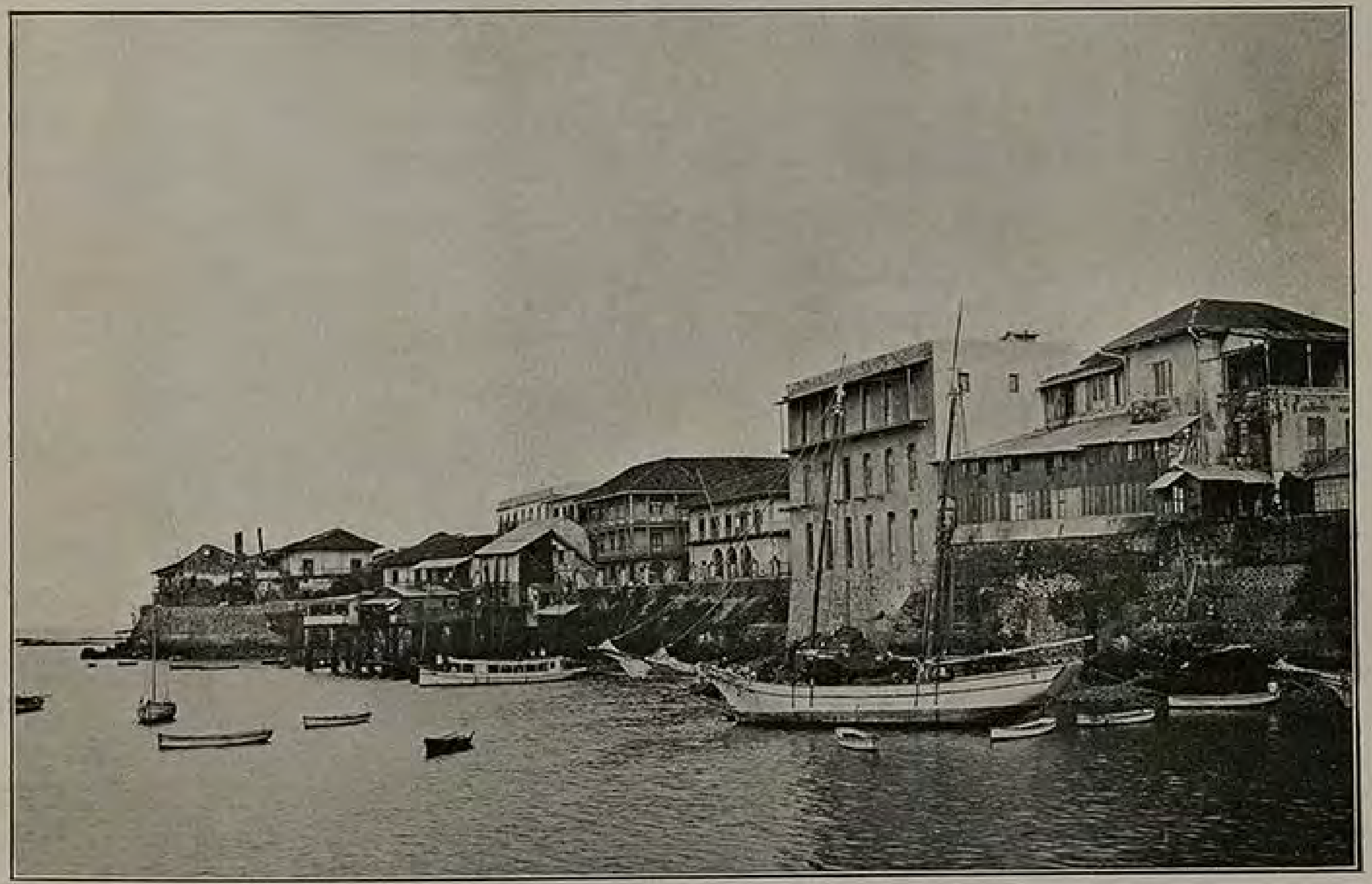

To face page 232.

WHERE PANAMA LOOKS ON THE PACIFIC. 
ONE could not write the word without a note of exclamation when I was in Paris fifteen years ago, and to say it aloud on the boulevards was to risk an exhibition of the savate, for it had untied many a treasure-stocking, and the thrifty bourgeois was infuriated by a fiasco that swallowed up his hardearned francs. Not even the tragic fall of the man who had made Suez and conceived Panama could appease his outraged countrymen. Had anyone told me at the time that I should one day see the Canal in a fair way of realisation, I should have thought the prophecy twice false, for there was then no prospect of my voyaging to those parts, nor did I, or anyone else, imagine that the scheme would ever see fruition under a Government capable of carrying it through. Kismet! I have seen the Canal, and ships will navigate it.

It was with no little interest that I walked down the gangway of the Tagus one Sunday morning after early coffee and found myself on the historic Isthmus that has within a few years witnessed the most gigantic engineering failure and the most bloodless revolution of our time. Within a few minutes I had passed the frontier of the Isthmian Zone and was once more, so to speak, on American territory, and the whole tragedy of the French evacuation came back as I stood under the 
shady trees in the Cristobal quarter, beside the statue of Columbus, and contemplated the transformation of the simple house of De Lesseps into offices of the Canal Commission. Surely to-day the word that once all but plunged our friends across the Channel in the throes of civil war marks the flood-tide of American daring in an enterprise at once commercial and Quixotic.

At the time when Panama was erected into a republic independent of Colombia, with the unconcealed connivance of Washington, it was pointed out in England, with some unnecessary heat (since the matter in no way concerned ourselves), that the instructions issued by $\mathrm{Mr}$ Roosevelt and his Government to the Nashville, then conveniently cruising in Isthmian waters, involved a gross breach of international etiquette, if not indeed of international law. It was further hinted that Washington took a very different view of such amenities when, forty years earlier, Europe was in favour of recognising the belligerent rights of the South. Of course it did. Equally of course, it took the view which best suited its aims on the more recent occasion. These criticisms are always regrettable on the part of any nation in respect of the affairs of a neighbour; from England, which without centuries of such arbitrary action could never have reared the splendid fabric of those oversea possessions, at once the glory of the Empire and the envy of the world, they are the snuffles of Chadband. Colombia put obstacles in the way of the Canal, Washington removed them: it is the game of chess that nations play for all time. On the face of it, the conduct of the 


\section{FLORIDA AND THE WEST INDIES 235}

American Government was constitutional, if not irreproachable. Seen from within, it smacked of piracy, but so without a doubt did the processes by which the British Empire acquired one-fifth of the surface of the globe.

Anyhow, the way is clear. Completion, even of the cheaper and more expeditious lock type favoured by the President and late Chief Engineer, $\mathrm{Mr}$ Stevens, may take eight years and fifty millions of dollars, and the sea-level type, to which many experts give the preference, would cost more in both time and money. Money, it is perhaps a platitude to remark, is no object to Americans, and even time is of less moment to a nation in its youth than to others in their dotage.

At one time the route by way of Nicaragua was a serious rival, and capital was even invested in it, but, after the dreadful fate that has within a year befallen three great cities of the New World, we shall hear no more in favour of a region so subject to earthquake and volcanic eruption, and it seems indeed probable that Nicaragua owed much of its popularity to the distrust engendered by two failures in the very name of Panama. The nation began to think that the project would smell sweeter by any other.

That America is going to see this great work through to a finish many people in Europe, and not a few even in the States, profess to doubt; but a visit to the Culebra Cut would dispel any such illusion, for it is obvious at a glance that the immense staff of control works with extraordinary harmony, encouraged, it seemed at any rate to me, by some impulse greater than the mere earning 


\section{SUNSHINE AND SPORT IN}

of high salaries. I have referred to the partmercenary, part-Quixotic nature of the enterprise from first to last, and this dual interest, I venture to think, inspires all concerned, from the President, throughout the most loyal and unflinching advocate the undertaking ever had in America, down to the youngest clerk in the offices of the Commission. It is not probable that the Frenchmen who formerly filled every position on the Isthmus were moved by any such spirit. They were far from home, a condition intolerable to men of that nation, and they were in constant fear of the fiasco that came at last. Even De Lesseps must have foreseen it long before the end. Well, his name has been execrated in his own country loudly enough to bias even the Recording Angel, yet not one of the Americans on the Isthmus with whom I discussed him and his scheme doubted for a moment that he was more sinned against than sinning, and the victim of bad luck rather than the defrauder of the small investor that his enemies depicted him. It must be remembered that Americans on the Isthmus have already had some opportunities of estimating the huge difficulties that confronted him. I venture to think that, before they are through with it, they will have some more.

The hostility of a section of Americans to the construction of the Canal by the Government is either political or economical. Opposition of the first kind is aimed at the men, or rather at the man, and not at the measure; and those who seize every opportunity of condemning Mr Roosevelt's policy naturally revel in such adverse reports of the state of affairs in the Isthmus as those sent home by 


\section{FLORIDA AND THE WEST INDIES 237}

$\mathrm{Mr}$ Poulteney Bigelow. More serious is the criticism of the Canal on sternly economic grounds. It is quite conceivable that a party attaching no importance to overseas expansion, and deprecating every attempt at aggrandisement outside the Continent, might honestly see in the scheme a costly and unproductive chimera. It is not indeed clear that the Canal will, within a reasonable time from its opening, even if we exclude the sums paid by the American Government to the former Company and to the State of Panama, pay fair interest on the immense amount of capital sunk in its construction. It is certain that Washington has not embarked on the work solely to swell the public revenues. One need not be a financier to realise the severe competition against which the Panama Canal will from its opening have to fight, for an atlas and a foot-rule will prove it. The rival that obviously suggests itself is Suez, and it is a curious irony of fate that the waterway between Asia and Africa will for ever avenge the memory of its creator by robbing the newer canal of Australian traffic that it would otherwise have enjoyed. Suez brings Sydney a thousand miles at least nearer London than Panama, and without a doubt the Suez tolls, at present considerably higher than those planned for Panama, will be brought down to meet the new competitor. The Horn route, on the other hand, has only the absence of tolls in its favour. Apart from this, the saving in time by Panama will be very great-eighteen days, for instance, between Plymouth and Callao. These are but two of the many cases that have to be considered before arriving at any estimate of the probable volume of 
business awaiting the Canal, so that it is not to be wondered at that there should be some conflict of opinion in shipping circles on the position it is likely to hold among the highways of the world's trade. Nor, in these circumstances, is it remarkable that American economists of a certain school should question the wisdom of such an undertaking, involving a known expenditure, but wholly unknown returns, by Government instead of by private enterprise.

In England, the Panama Canal has, apart from its political aspect and the technical interest that it has for engineers, excited little attention. Here and there a few writers in the press have speculated on its possible effects on the trade of Britain, and some of the hypotheses even include the tragical deflection of the Gulf Stream into the Pacific in the event of the dams bursting, as well as the conveyance of the yellow-fever microbe into our Indian Empire, which has so far been practically immune from the ravages of that terrible epidemic. With the alleged climatic cataclysm claimed by physiographers as the direct result of the divergence of the Gulf Stream I have not sufficient knowledge to concern myself. The other apprehension, which I believe originated with that eminent worker in tropical diseases, Sir Patrick Manson, rests on the hypothesis that the carriage of Stegomyia from the Caribbean into Asia has hitherto been precluded by the long and cold voyage via the Horn, in the course of which the mosquito would be either blown away or frozen to death. The opening of the Panama Canal, on the other hand, would, it is argued, afford that scourge a short, tropical route from the West 


\section{FLORIDA AND THE WEST INDIES 239}

to the East Indies, with, it is believed, fatal results. I hesitate to dispute the forecast of so great an authority, but it seems just worth mentioning (what, of course, he is perfectly aware of) that there has for years been direct steamship communication between Panama, which stands at one end of the Canal, and the Asiatic ports concerned, with connecting transportation by railroad from the other seaboard. Why, then, should the danger be any greater, seeing that Stegomyia, in the form of egg, larva or perfect insect, can be carried by a variety of agencies, with direct communication by water? Indeed, even the railroad communication may be eliminated from the argument, since, previous at any rate to the great work carried out by Colonel Gorgas and his energetic brigade, Stegomyia was quite as abundant in the vicinity of the Pacific port as on the other side of the Isthmus. And this fear of the admission of yellow fever into our Asiatic possessions seems to me to make altogether too little of what has already been accomplished, and what will doubtless be accomplished in the near future, and years before a single vessel can pass the Bocas, by the sanitary authorities, under the supervision of the man who did so much for Havana, waging against the brindled insect a longer and fiercer war than his fellow-officers waged against the Spaniard.

Whether the Canal is interesting or not from such distant standpoints as New York and London, its grip on the visitor privileged to see as much as has been done is undeniable. Indeed, the region, apart from its mutilation in order to join two oceans, is in itself of amazing interest to the 
naturalist. One of the strangest sensations, such as cannot be experienced even at Port Said and Suez, which lie much further apart and have no connecting train, is to stand on the shores of two oceans between breakfast and lunch. Wandering that Sunday on both foreshores, I was struck with the apparent similarity of the seaweeds. I say "apparent," for I trusted to a memory only three or four hours old and did not actually compare specimens. This harmony in the wind-drift tangle from the sea-gardens tells us far more surely than any corresponding resemblance in the land plants of both seaboards that the Isthmus was submerged at no very remote period as geologists reckon time, for the land plants have other modes of dispersal.

It looks therefore as if the dream that killed De Lesseps and the reality that is occupying Washington is a restoration rather than a creation, and that this proposed sundering of two continents the better to unite two oceans so distantly connected is nothing but a return to prehistoric conditions.

On other grounds, the two aspects of the Isthmus differ, particularly in such characters as are derived from a contrast between the fierce ebb and flow of the Pacific and the calm stagnation of the Caribbean. At Colon, a town that stands on stilts, knee-deep in a marshland beloved of mosquitoes, there is so little tide that the largest yessels of the Royal Mail line berth at any time alongside the wharf. Panama, on the other hand, exhibits rather the conditions of those well-known homely resorts that defiantly urge their nominal claim to a marine outlook, to wit Southend-on-Sea and Weston-super-Mare, gazing at low tide over 
acres of uncovered mudflats at the distant waves, offending the nose, but gladdening offal-hunters like the turkey-buzzard. At high-water, Panama has more beauty in its frontage than either of the towns named, though one of them at least is not unlovely in the sunset; but even so, the muddy water of the southern Bocas is of very different quality from that other shore of the Pacific where I last took leave of it in the opal deeps of Whitsunday Passage and the verdant channel of Albany Pass.

Contrast with the Suez Canal will unavoidably suggest itself, first by comparison between Colon, with its strange survivals of the French occupation, its populace of "Spiggoties" and the brisk American invasion within the Zone beyond the American post-office, and that sink of inexpensive iniquity, Port Said, which festers in an atmosphere of coal-dust and trite immorality at the northern end of the older waterway. To those who cross Panama on water the contrast will doubtless present itself still more vividly. Few landscapes could be more widely divergent than the rampant jungle of Panama and the treeless desert of Lower Egypt. Along the hundred miles, or very little less, that separate Port Said from Suez, the sand lies low and level, and such watery interludes as were there before the finest engineers in France let in a sea to meet an ocean were all in their favour. At Panama the Americans have to cut their way through solid rock, and are confronted with a river that alternates between an unnavigable fever-breeding ditch and an ungovernable torrent capable of rising seventy feet from one sunrise to Q 
the next. Brindley, the engineer, was of opinion that rivers were made that they might feed canals, but he did not know the Chagres. It drove the French to despair; and the Americans have not yet mastered its vagaries. Indeed, they have Nature in her most hostile mood up against them; a rank luxuriance of vegetation beyond all control, a damp climate that corrodes machinery almost in action and makes man limp, and stubborn rock that taxes even the brutal forces of ninety-ton steam-shovels.

Yet both scenery and climate will come as an agreeable disappointment to those who have drawn their inspiration from the gloomy descriptions of home-sick employés. To Dampier and his devoted band, who crossed it on foot that rainy spring of $\mathrm{I} 68 \mathrm{I}$, the Isthmus was "damnably heartbreaking," and so, no doubt, it remains to any footsore tramp without the price of a railway ticket. Seen comfortably through the eyes of what natives of tropical seaports have learnt to call, without discrimination, "damfool Cook," the tropical vegetation and brilliant colouring of land and sky, with traveller's-palm, tree-fern, towering timber festooned with lianas and jewelled with orchids; picturesque native villages in the foreground; further back, hazy mountains that send down their gathering torrents to feed all this rank verdure of the plains, make a far from unpleasant picture. To those, I say, who have based their anticipations of the country on the accounts posted home by disillusioned exiles, the first impression of the Isthmus will be a revelation, for the gay bird of passage, who has but to flit back to the ship 


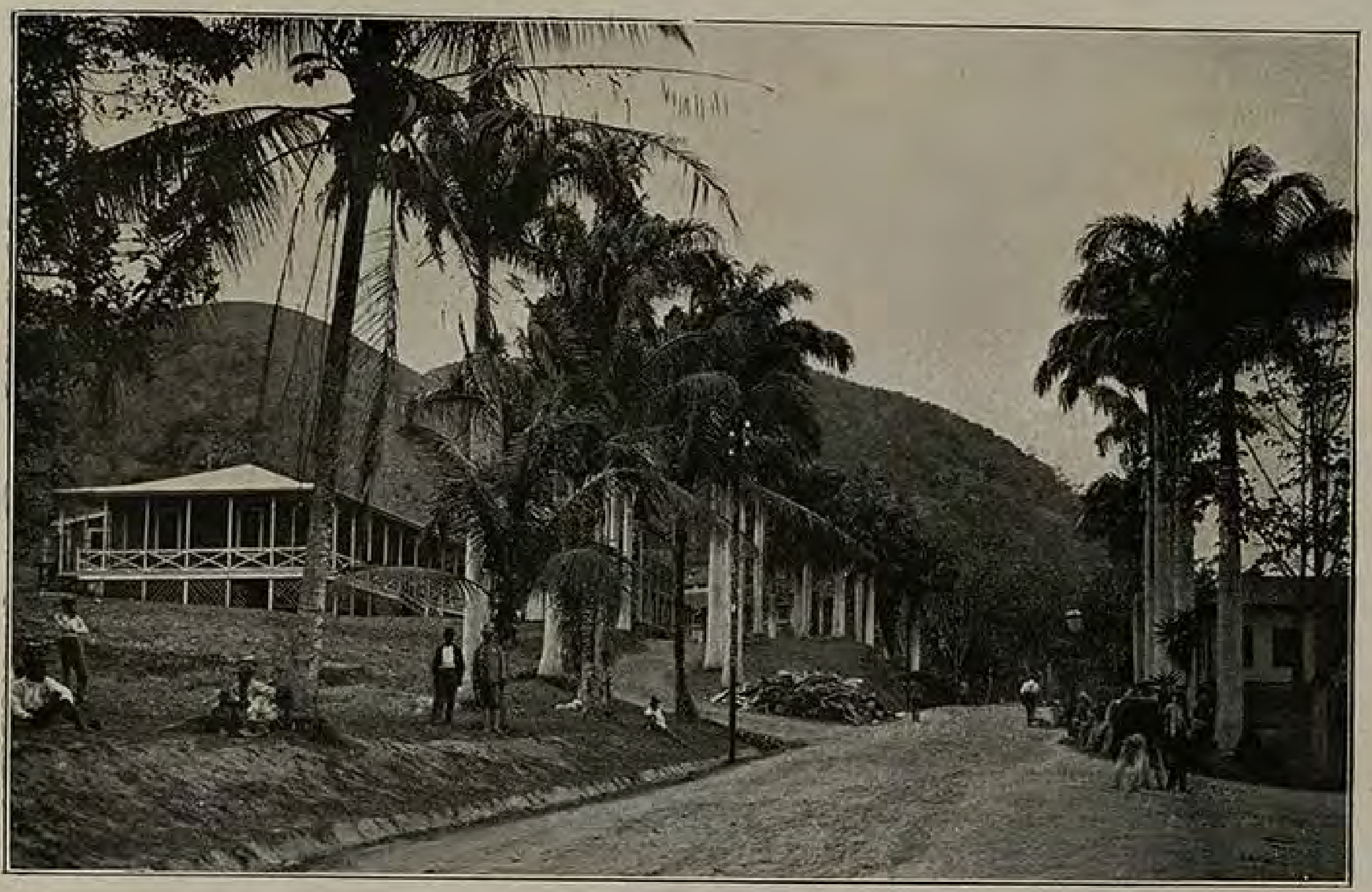

THE HOSPITAL AT ANCON.

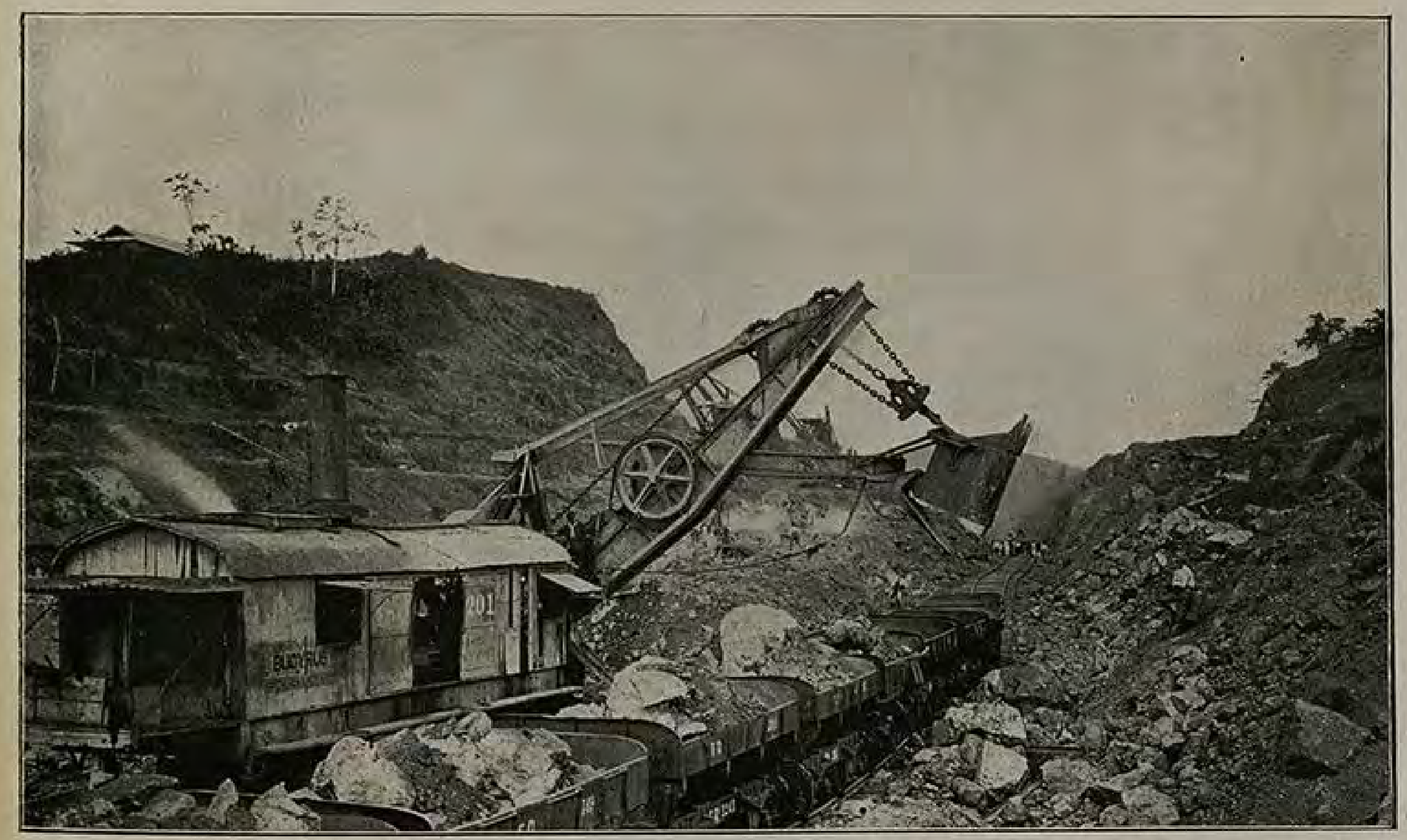

To face page 242.

STEAM SHOVEL IN THE CULEBRA CUT. 
when surfeited, cannot realise the nostalgia of the exile. Those who have smelt the tropics under other skies guess at the darker hidden side of all this hothouse pageantry of the equatorial jungle, and are glad enough to make the Isthmian transit asleep and behind drawn blinds.

Panama, for all its pleasing outlook (at high tide) over the great western ocean that is to mean so much in the future greatness of America, is not noticeable for either streets or public buildings. Its most beautiful suburb is Ancon, where, on gentle hills within the Zone, stands the famous hospital, a legacy of the French occupation ably and conscientiously administered by their successors. Here, in what is perhaps without exception the most perfect tropical sanatorium in existence, as well as in smaller affiliated hospitals and dispensaries at Culebra, Empire, Miraflores and other points on the Isthmus, Colonel Gorgas and his staff have charge of the health of twenty or thirty thousand residents, most of them the coloured employés of the Commission. Malaria and pneumonia, the latter very prevalent among the negroes from the islands, are the chief troubles that have to be dealt with; but of yellow fever, the epidemic which carelessly-informed persons continue to associate with the Isthmus, cases have for a long while been so rare that a suspect, whom I saw in one of the wards, through which I went with Colonel Gorgas, was engaging the concentrated attention of half the staff. In addition to ordinary hospital work, the Americans are busy cleaning up this unclean corner of earth and ridding the settled portions of Anopheles and Stegomyia, which have 


\section{SUNSHINE AND SPORT IN}

jointly been responsible for so much of its bad reputation in the past. If these pestilential agents of sickness were as enterprising as the Southern Express Company, the problem of their suppression would be such as to baffle all the resources brought to bear on it. Fortunately for the human race, heir to all the ills they carry about with them, these gnats live their mischievous lives within a very limited area, flying (unless borne by the wind) but a little distance from their watery birthplace. It is therefore practicable to eradicate them, so far as the dissemination of disease by their agency is concerned, for a clear radius of five hundred yards round human dwellings is probably sufficient to insure immunity from their attacks. Of exterminating Stegomyia in every remote district of the Isthmus there is no hope or need. The work taken up by Colonel Gorgas and his assistants is very thorough, embracing street-cleaning (on the principles that answered so successfully in the city of Havana), whitewashing houses, the free distribution of pure water, and actual warfare on the mosquito. This campaign against a small and irreconcilable foe includes the cleaning out of tanks, wells, cisterns, calabashes and any and every likely breeding-place, filling up ditches with great stones so as to make it impossible for stagnant water to lie anywhere, oiling such water as cannot be got rid of by placing over it five-gallon barrels that drip slowly on the surface, or even impregnating it with copper sulphate, which kills the algæ that afford cover for the larvæ of Anopheles. Native huts are fumigated with sulphur and pyrethrum, gutters are closed, crab-holes (favourite 


\section{FLORIDA AND THE WEST INDIES 245}

nurseries with several kinds of mosquito) are oiled, such undergrowth as might hide either stagnant water or hatches of the insect is forcibly removed. There is no end to this great work of cleaning out the Augean stables, and it is woefully unfair to those engaged on it to express any apprehension of the geographical enlargement of yellow fever from its centre of distribution in the Caribbean until they have had a fair chance of showing what they can do to combat such a result.

Of the other interest of the Isthmus, the engineering work of the past, present, and future, the limitations of a brain impatient of mathematical formulæ and mechanical principles prevented my enjoying an intelligent view. Only my own ignorance was to thank for the very slight impression I brought away from the Culebra Cut, for thanks to the courtesy of $\mathrm{Mr}$ Sullivan, acting chief engineer during the absence of his chief at Washington, I was given an excellent insight into what was going on. Running smoothly up and down the tracks on his private Oldsmobile, listening to his entertaining comments on the difficulties and the triumphs, with practical illustration by the small drills and gigantic steam-shovels, I had, thanks to arrangements made by Colonel Gorgas, a most enjoyable day, but find myself quite unable to give the information that the reader will reasonably expect. What most impressed me, perhaps, was first the colossal strength of these great shovels, each of which, like a mammoth guided by a couple of puny men, savagely tears up the rock and dirt as an elephant would gather leaves, the huge arm swinging round in search of new loads absolutely like an 


\section{SUNSHINE AND SPORT IN}

immense trunk extended for buns ; and after that, the saddening contrast of rusty pyramids of obsolete French machinery with all the new plant proudly brought over from Scotch and American yards. I was also agreeably struck by the somewhat indignant refusal of Mr Sullivan's chauffeur to accept a gratuity. I am induced to mention this, not as any advertisement of my own generosity, which is slender, but rather as a caution to others, for there are few positions more embarrassing than that of the man whose "tip" is flatly declined. We had quite a friendly talk on the subject, a kind of mutual apology, during which he told me that he had taken me for an American until I offered the fatal bill; after that, he knew that I came from the other side. $\mathrm{He}$ was, he said, in receipt of good pay from his employers, and our tour that morning had been in the ordinary course of the day's work. Otempora! O mores! Why can they not make this worthy young man head keeper on the biggest shoot I am ever asked to!

In spite of a hundred ingenious labour-saving devices, smaller, but not in their way less efficient than the huge shovels, an immense amount of unskilled labour (upwards of twenty thousand men, mostly from the islands) has to be employed in the work of construction. In that climate, only skilled labour can be done by white men, so that the work of recruiting the rest has involved the Commission in some difficulty and much expense. The chief source of supply has for a considerable period been Jamaica, which has contributed thousands of niggers under a recognised system of deposit and other conditions that attach to indentured labour, 


\section{SUNSHINE AND SPORT IN}

be more manageable than one of homogeneous origin.

Colon and Panama should, from all accounts, offer good sea-fishing, and it would indeed be an amusing experience to fish in two oceans in one day. I hope to do this on a future visit. At the Caribbean port, at least, I can answer for the presence of tarpon in the month of June. Captain Laws (of the Tagus) and I fished over the stern one evening, and a score of these great fish, each weighing probably forty or fifty pounds, rose like trout at such shreds of "bully beef" as we threw to them, but fought shy of our hooks with a discernment surprising even when we remember the crystal clear water and bright light of those anchorages. They cannot surely have had much education in the ways of fishermen, though no doubt baited hooks are often lowered from the wharf or from vessels moored alongside. Only one hook was taken, and my tarpon-rod was all but wrenched out of the Captain's hand, but after one convulsive splash, the hook came away. On a subsequent visit, Captain Laws succeeded in capturing a brace. Angled for with tarpon-tackle from a boat in the early hours of morning, I believe that these mighty fish would give splendid sport, and indeed all along the Royal Mail route there is excellent sea-fishing, with bully beef as the pièce de résistance. Fishes great and fishes small dash madly at it so long as it hides no hook, but they are endowed right down the Spanish Main with this same curious distrust. Moreover, it is a difficult material to bait with. $\mathrm{Mr}$ Laws knew the way of it, which consists in doubling up some shreds and squeezing a lump into sufficient 


\section{FLORIDA AND THE WEST INDIES 249}

consistency to give the hook purchase. Otherwise, if this be not done with extreme care, the beef washes off the hook the moment it is in the water. The next time I visit those seas, it will be with exceedingly fine gear. So clear is the water that the fish are frightened by tackle that in our foggier bays at home deceives anything that swims. 


\section{IV \\ THE SPANISH MAIN}

The Spanish Main is so bound up with the old romance of bloodshed and loot, of sunken galleons and of British piracy, so pregnant with memories of Westward Ho! and Roderick Random, that to discourse in cold blood of its sea-fishing possibilities is enough to make those old neglected ghosts rise from their cerements. All the same, one of my fondest memories of Cartagena will always be the bucketful of snapper and yellowtail that, in company with the Captain and Captain Benson, the well-known travel lecturer, I caught on the wharf, my old trout-rod bending gaily every few moments as each fish tried hard to break the gut collar and escape beneath the piles.

Yet Cartagena is worth more attention than that bestowed on the fishes of its docks. To get to it, steamers are compelled to make a long détour round an island, giving passengers the impression that the steamer is not going to call at the port at all. The reason for this roundabout approach is that, at some period in the eighteenth century, the citizens, weary of having their city ravaged alternately by English and French pirates, blocked up the proper entrance to the harbour, and the barricades have never been removed. This adds, if I remember right, an hour to the journey from the outer sea, and I should imagine that the Colombian 250 


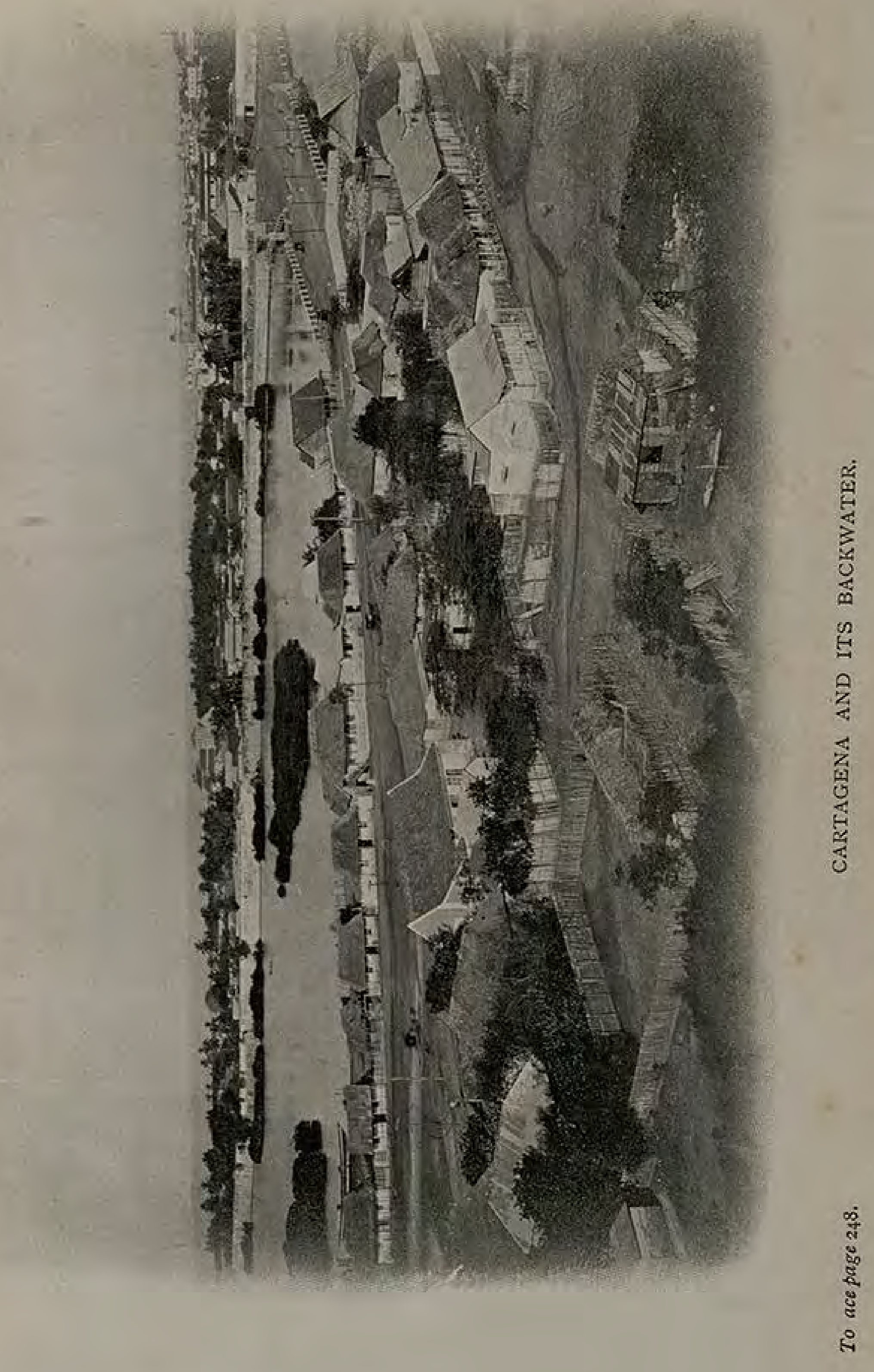


Government would do well to throw the short cut open once more, though I have not the faintest idea what such an improvement would cost. It is a fishful anchorage, and as far back as the glorious days of Drake, the abundance of good fish in those waters was acknowledged by every adventurer who sacked a church or robbed a nunnery.

A recent writer on the Spanish Main, referring to the escapades of Drake, commiserates the buccaneers at Panama as having had a slow time of it, since "there could have been nothing for them to do, save go a-fishing." Well, I have not in my veins the blood of buccaneers (for which I offer every apology), but am a mild, unenterprising creature, to whom the capture of sea-fish offers greater attractions than even the cutting of throats. An old writer has it that there was "great plenty" of fish in the creeks round Cartagena, and I am convinced that the extraordinary wealth of fish on that coast is as yet but imperfectly understood. With constantly improved methods of cold storage and transportation, as well as the increasing exhaustion of grounds nearer home, this untouched harvest of the Spanish Main appeals to me strongly, and I hope on some future occasion to deal with it at greater length in the light of a more intimate acquaintance.

At all the Colombian ports, and in those of Venezuela, all manner of live stock, including monkeys, macaws, agoutis, hawks, snakes and the like, is offered for sale. Passengers buy these freely for reasons best known to themselves, but few survive the ordeal of the voyage. It is iniquitous to attempt to evade the Company's rules 
by smuggling such gruesome merchandise into private cabins. It is unfair on the Company and on the animals themselves. The Butcher's Shop is their proper destination, and the butcher on the Tagus, a most obliging fellow, looked after an immense family of charges with great solicitude and quite unusual success.

The history of Cartagena goes back, I believe, about four hundred years, and its chief claim on the notice of the historian is its long connection with the honourable and painstaking body of the Inquisition. The official headquarters of the pious institution is now a private residence and store, situated in the same square as the cool and comfortable club to which $\mathrm{Mr}$ Fearon took me for light refreshment after a most enjoyable drive around the city. Here, even after such methods had fallen into disrepute in Spain itself, the Inquisitors practised their ingenious tricks of taking evidence by surgery, and the auto-da-fé flamed merrily on the still shores of the Caribbean long after the blaze of its dyingembers had gone out in Europe.

The walls of the city, which to-day, despite the thickness of their masonry, look capable of withstanding the attack of no enemy more serious than tin soldiers, gave a good account of themselves against Vernon and other licensed freebooters commissioned to chase the Spanish plate ships. The cathedral has a magnificent font, a gaudy screen, and a crypt full of ancient skulls, into which the fossil in charge declined to let me descend, for fear, he said, of lethal emanations. Near the walls is a private chapel containing a beautiful piece of 

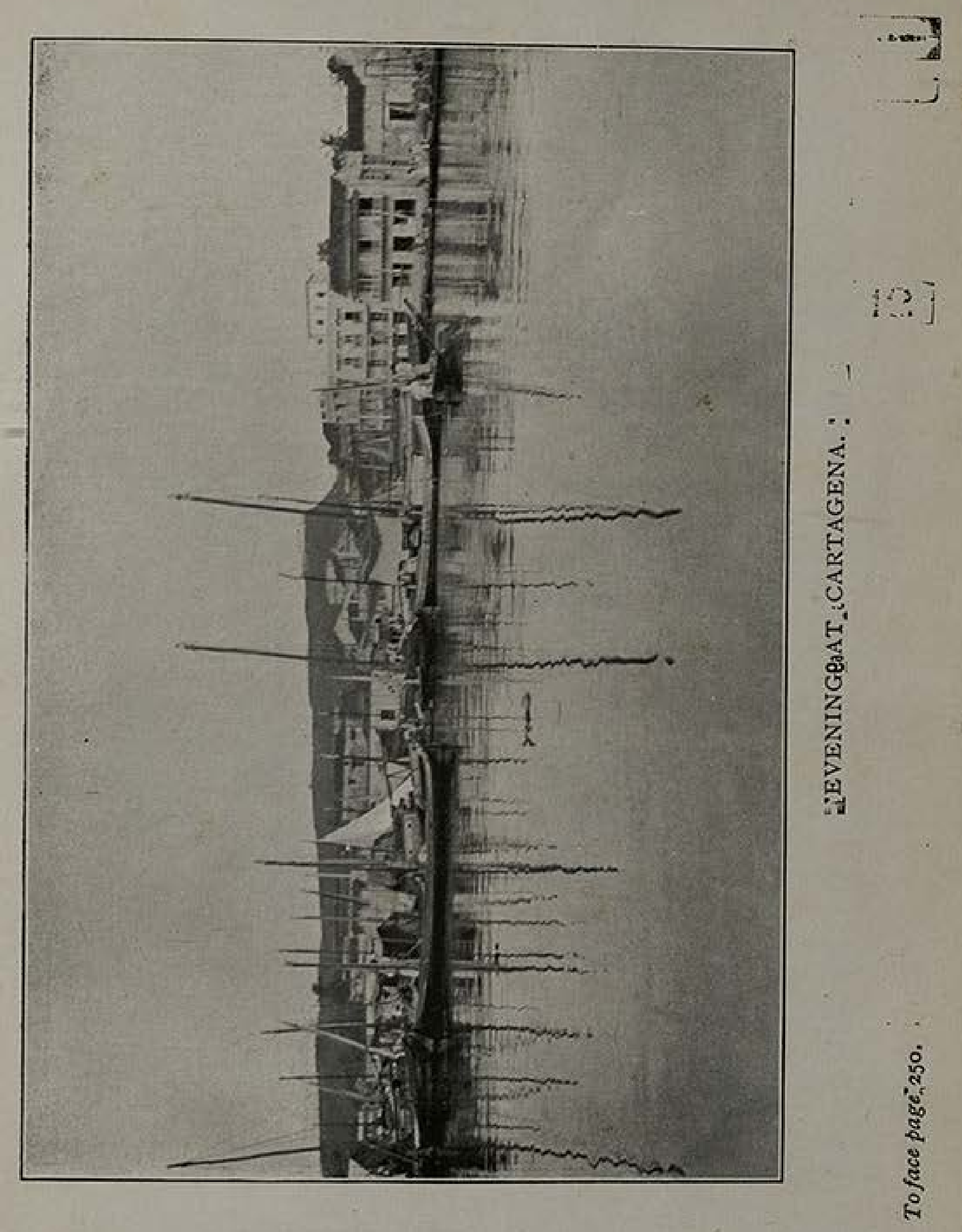
two fishermen, since concealment in such sunshine is out of the question. Our failure was on this occasion partly due, no doubt, to the proximity of two or three large sharks, whose dorsal fins cut the oily surface of the sea not a hundred yards away, as well as to the somewhat clumsy manœuvring of a large Spanish steamer, which left two or three hours before the Tagus. Ordinarily, Captain Laws regards Porto Colombia as the best spot for the fisherman on all the route. Otherwise, I imagine that its shallow anchorage, threatened with the silt of the Magdalena, does not make it popular with R.M.S. commanders.

La Guaira, with all its memories of Amyas Leigh and Rose Salterne, is picturesquely situated, in a temperature about which Dante and Milton have something to say, between the green mountains and the blue sea. The heat, even in June, is so oppressive that it makes the eyes ache just to look at the town from the ship. If the latter stays overnight, no time should be lost in taking the train to Zigzag and Caracas, which is, I understand, one of the most remarkable short railroad jaunts in all the world. Like the excellent breakwater, the line was constructed with British capital. The harbour was, when we anchored there, simply alive with fish-snappers, Spanish mackerel and catfish for the most part-but they were wary, and the clear water made mockery of our wiles. Some "Spiggoties," fishing off the quay, knew the trick better. Flinging out a long line, carrying a single large hook baited with a live garfish, into a boiling eddy in which some large fish was evidently harassing small fry, one of them soon landed a large barra- 


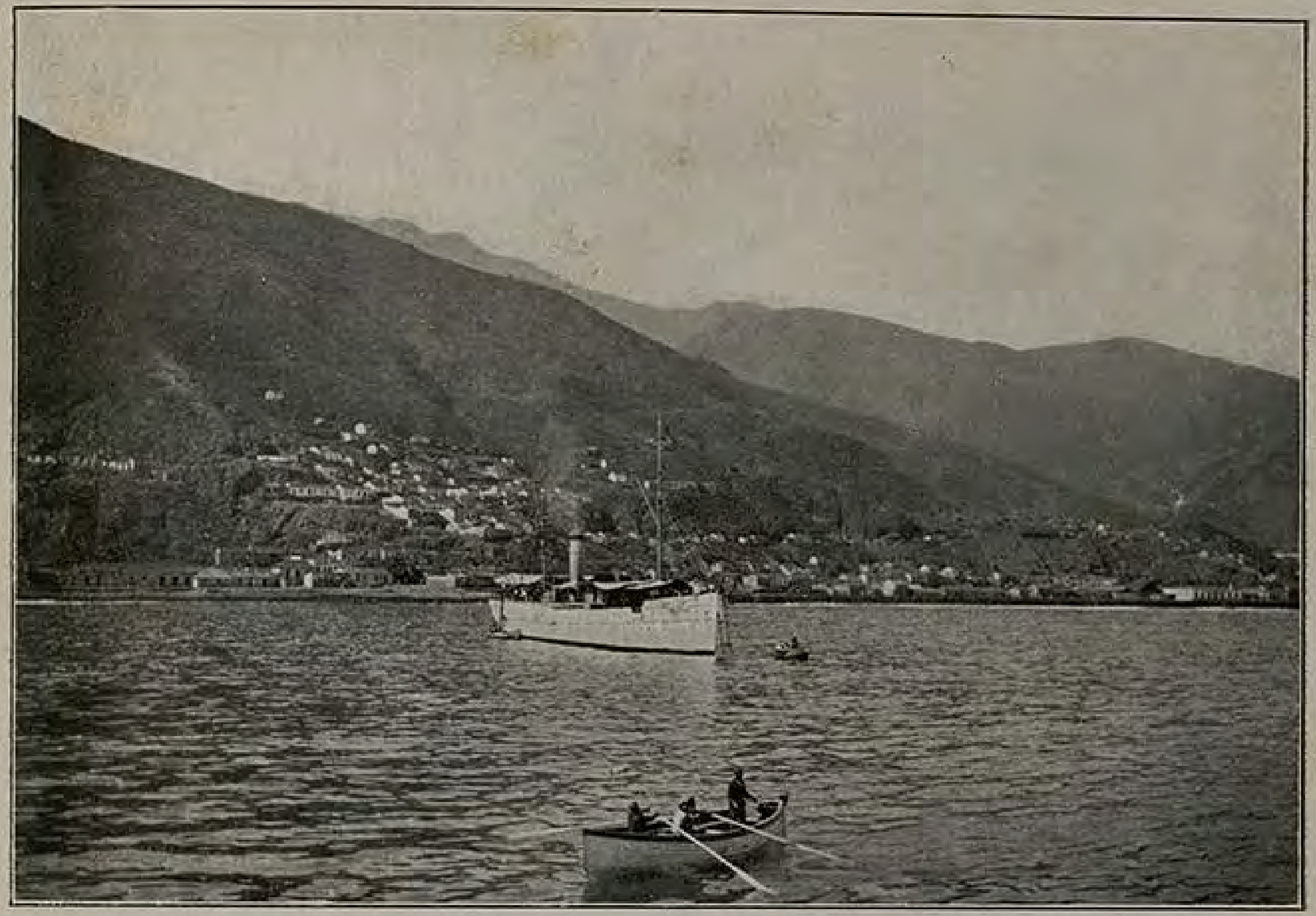

LA GUAIRA THE DAZZLING.

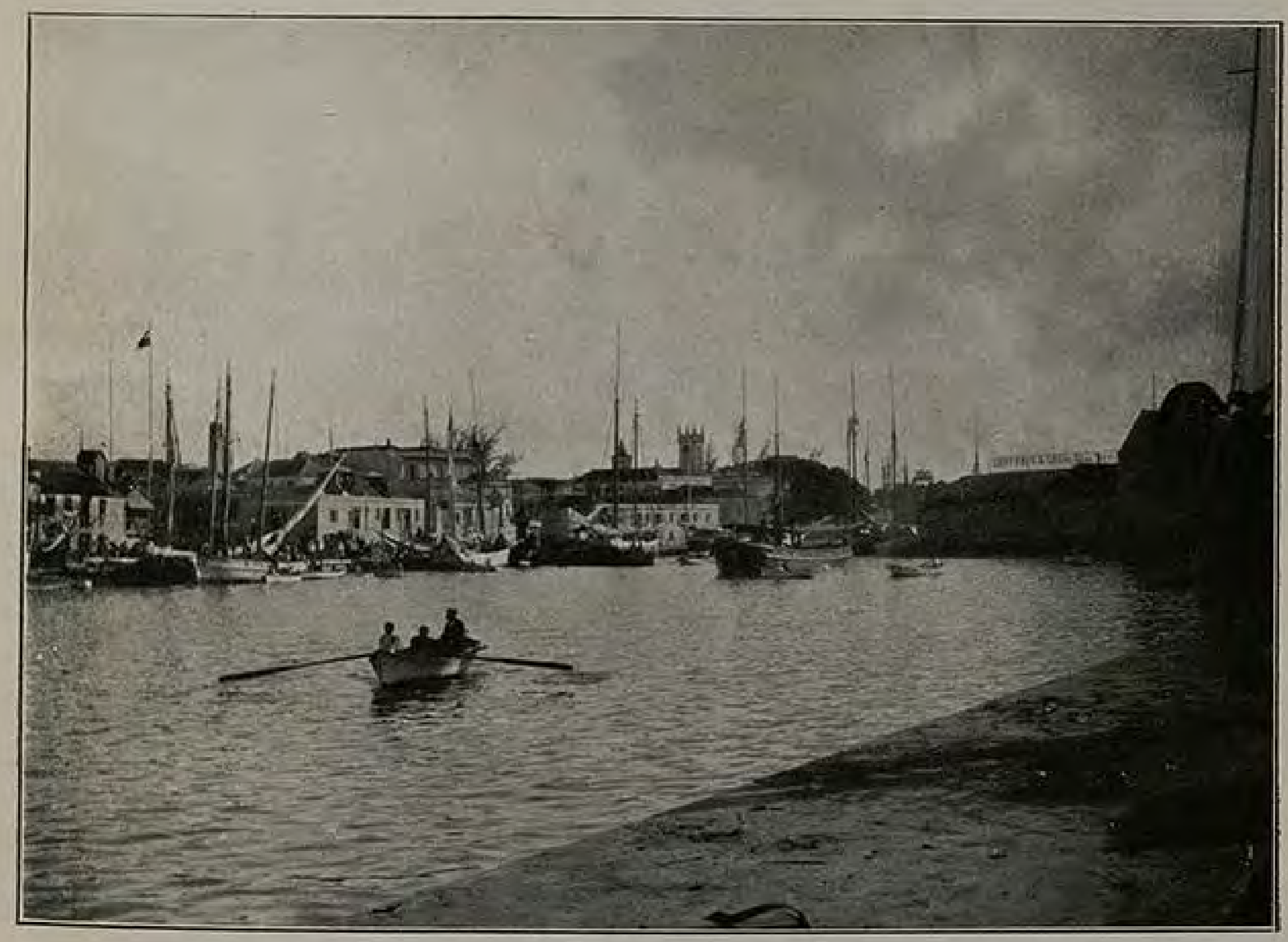

To face page 254.

WINDSWEPT BRIDGTOWN. 


\section{FLORIDA AND THE WEST INDIES 255}

couta of perhaps fifteen or twenty pounds. Captain Benson promptly bought the successful fisherman's tackle as it was, for, I think, a shilling, only to lose it within five minutes in the rocks.

At La Guaira the ship's company received a most interesting addition in the shape of eight humming-birds and a large number of troupials and starlings, sugar-birds and other small Venezuelan fowl, which Captain Pam was bringing home with him as a present for the Zoological Gardens. It may be remembered that this gentleman succeeded a year earlier in bringing home the only hummingbird ever shown alive in London. It reached England in November and lived just eighteen days. On this occasion, starting with so many in the best of summer weather, he reasonably hoped for better results. Everything was arranged for their comfort on the voyage. By the kindness of the Captain, the now disused Forrest wireless telegraphy house on the spar-deck, vacant after $\mathrm{La}$ Guaira, was turned into a floating fragment of their native jungle. Untiringly $\mathrm{Mr} \mathrm{Pam}$ fed and tended his delicate little favourites for a fortnight, looking carefully after their change of water and stock of syrup, and feeding them by hand when they seemed backward to take nourishment. Many times I went the rounds with him. One died of cold ; a second apparently succumbed to exhaustion; a third fell in the drinking-trough and was drowned; a fourth starved to death from some injury to the fragile muscles of the tongue, which we were unable to relieve. Before, therefore, we were in home waters their plight was approximating that of the Ten Little Nigger Boys, but 
happily there were no more casualties, and on the day we reached Southampton four were safely handed over to $\mathrm{Mr}$ Thomson, head keeper of the Zoo, who met the boat to take charge of them. Alas for all the care lavished on them! The long voyage or the new climate did their work only too swiftly. Alas for the special cage built for them in the Insect House! Before anyone had a chance of seeing these feathered treasures from the neotropical jungle, they were all dead. 
HOME BY THE ISLANDS

THE remaining two ports of call are once more insular, though Trinidad, the first of them, is no part of the Antilles, either Windward or Leeward, but a detached fragment of South America. Hardly has the Tagus won clear of the Venezuelan shallows before, ploughing her way through mud sent down by the mighty Orinoco, she finds herself at rest off Port of Spain, the capital of Trinidad.

It is a lovely island; sugar and pitch are its wealth, and colour is less in the ascendant than in Jamaica, though the groups of Hindoo coolies on the countryside, and even in the capital, lend an Asiatic touch to the picture, accentuated by the apparition of Indian cattle grazing in the shady savannah. We are almost out of the trade-winds here, and the steamy climate recalls the lowlands of Ceylon.

Dinner at the Queen's Park Hotel is followed by a walk round the savannah, with clouds of fireflies rising before our feet. A sharp downpour of rain drives us back to the hotel. It generally rains at Port of Spain, and the damp and heat combined make a very trying climate, as a relief from which residents take their short leave at Barbados. There is no harbour to speak of; merely an open roadstead, and the R.M. vessels lie two or three miles from the landing. 
Beyond the welcome change of a day ashore, Port of Spain has not many attractions for so brief a visit, though I was much interested in the curio store opposite the wharf, and I ate, lunching at the delightful club with $\mathrm{Mr}$ Skinner, a pastel, the name of which, with sundry other dreams of the table, will be found graven on my heart when the College of Surgeons acquires that much-broken organ.

The Queen's Park Hotel possesses one of the most remarkable billiard-tables that I ever played on. My game is so fluky as to be no game at all, but I defy Lovejoy himself to come off on the Queen's Park table, and I imagine that the balls would run just as true in the savannah.

Bridgetown, the next and last port of call, is, climatically and otherwise, the antithesis of Port of Spain. Barbados is the most windward of all the Windward Islands, and the invigorating trade-winds blow there morning and evening, and sometimes afternoon and night as well. Like Jamaica, this is an island of blacks, who must number four to every white, and as it has 200,000 human beings to its 166 square miles, it is only less crowded than London or Pekin. No other island, no other country, no other continent is so packed for its size. The death, some time ago, of Theodore Paleologos, Emperor, at Barbados, lends a retrospective distinction in contrast with the otherwise homely interest of the place.

One memory of Bridgetown survives over and above its picturesque bridge, its truculent though merry niggers, and its sugar-cane, and that is a dish of fried flying-fish that $I$ ate at lunch at the club the day I was ashore there. A dish, did I say? A shoal! I have eaten many kinds of fish from 


\section{FLORIDA AND THE WEST INDIES}

twenty seas, and it is rarely that I hit upon a novelty that commands enthusiasm ; but I can fairly say that the flying-fish as served at the Bridgetown Club are too delicious for words, and are more fitly praised in a reverential silence like that of the "Devout Lover" when he sings-

"It is not mine to sing the stately grace, The great soul beaming in my lady's face."

His heart was too full for words : so was my mouth, and I wish it were so still, for I shall never taste the like again unless I go back there. Flyingfish swarm in the blue water round this healthy little island as on few other shores, and if only these delicious morsels could be brought alive to London, like the truite au bleu of the Carlton, here indeed would be a new industry to redeem Barbados from the stagnation into which the ups and downs (most of them downs) of sugar have thrown it. There is a glut of labour, in spite of the drain for Panama, and almost before the ship's anchor is down the coloured watermen fall over one another in significant eagerness for a job.

As a health resort, the island is favoured more by folk from Trinidad than by tourists from home; but its health-giving climate is above reproach, having been advertised long ago by the fact that George Washington visited the island and caught the smallpox there.

The Barbadian nigger is, as has already been said, a fighter. $\mathrm{He}$ is also nearer being an honest worker than anything else of his hue, and he and his women dress more neatly and appropriately than their cousins in Jamaica. The cousinship is not 
indeed very near, for the two are of different stock. I recollect an interesting suggestion made to me by Archdeacon Bindley, Principal of Codrington College, Barbados, that this difference of origin might perhaps account for the corresponding difference of temperament. The Barbadian, it appears, came from the Temne and Mende tribes of Sierra Leone, the Jamaican from the Kru and Slave Coast tribes furthersouth. Thus the less virile Jamaica black may have come from a lazier stock in equatorial Africa, retaining the disposition of the Kru boys, of whom Sir Harry Johnston wrote in his volume on Liberia that they are still " a noisy, self-assertive race of bullies, who are cowards when boldly faced or when placed in positions of danger." Dr Bindley also suggested that the happy contentment and quick temper of the Barbadian nigger may have been a bequest of the Irishmen transported hither by Cromwell !

The open roadstead off Bridgetown is good fishing-ground for the fighting cavalli, several of which, weighing three or four pounds, were caught and hauled on deck. These took both bully-beef and raw steak, though the latter, which is much easier to bait a hook with, proved unattractive at the earlier ports of call.

After Barbados is left astern, the interest of the homeward voyage is confined to the ship, and everything depends on the grace with which for the remainder of the time the passengers, bent on whiling away the "tedium of fantastic idleness," tolerate one another, a trying test of good-fellowship, which should not, however, plough anyone with his or her share of good-nature.

On this voyage everything went smoothly, and 


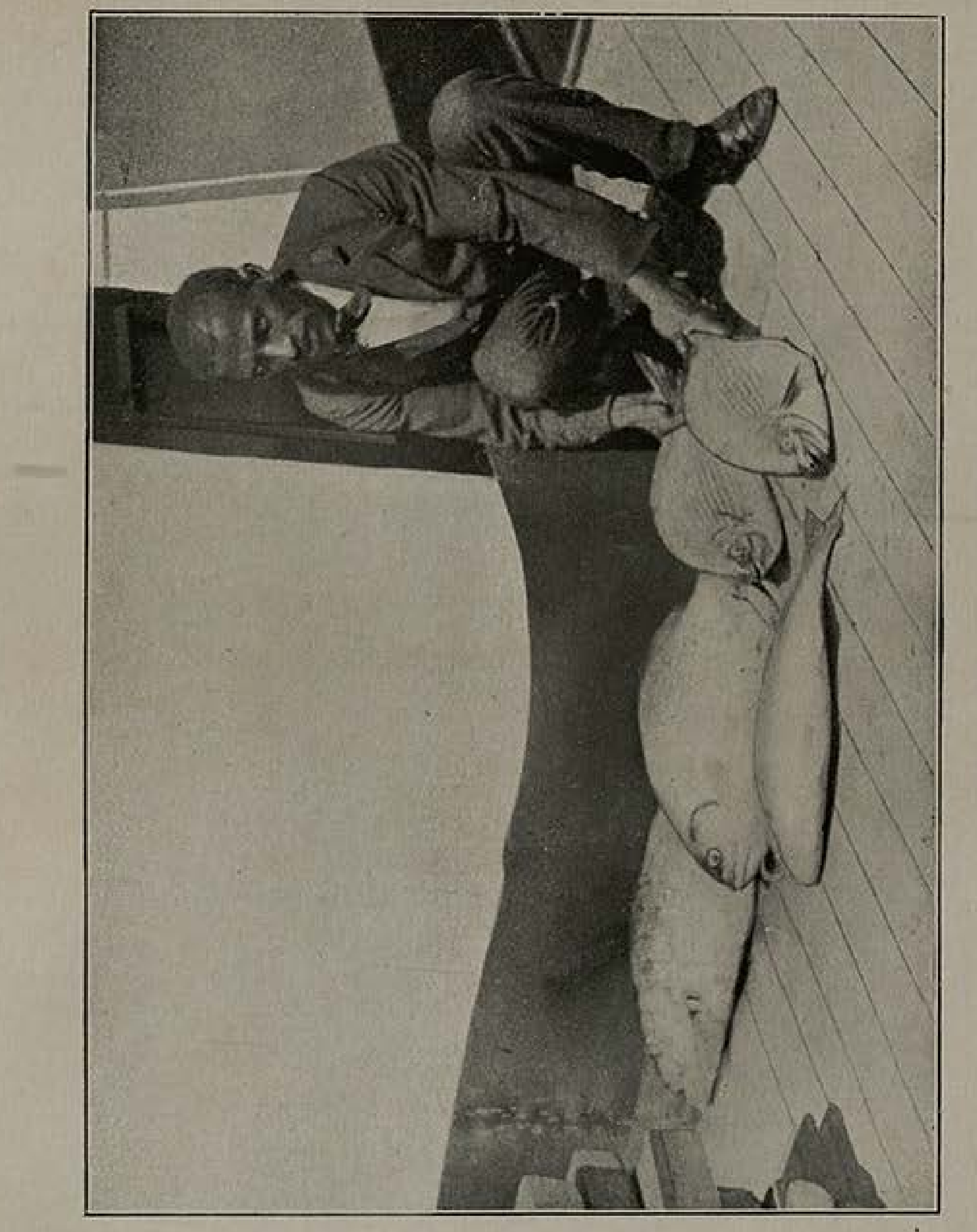

岁

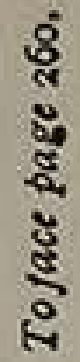


the sports, under the direction of Captain Benson, passed off admirably.

The last episode was our capture by three destroyers of the Blue Fleet, on the final afternoon of the manœuvres, during our run from the Lizard to Cherbourg. Our captors had lost their bearings, a useful predicament for an attacking fleet sent out to harry merchant shipping, and when we had given them the information asked for, they rudely signalled to ask whether we were going our full speed and to express the hope that we were not going slow out of deference to them. This must have been as honey to the Chief Engineer, who was purposely crawling along, as we should in any case have to lie all Sunday night in Southampton Water.

Two carrier pigeons from the destroyers flew on board the Tagus, and as everything is fair in war, Pam and I fed them with corn till they were too comfortable to fly any further, and captured them after dark when roosting on the home of the humming-birds. Next afternoon, after copying their cipher code messages, which we could not make head or tail of, we released them off Hurst Castle.

Daybreak on Monday found us alongside the wharf, and then came the usual leave-takings, the curiously abrupt and final break-up of the little community that had for a while been brought into such intimate fellowship. And now each would go his or her way and no more, perhaps, see any of the rest. Human nature is mercifully constructed so that it can break friendships as easily as it makes them. Human nature had to bear something else that July morning, for the first news to greet us on the landing was of the dreadful railway accident 
further down the line, at Salisbury, the day before. Ours was the first boat-train to run over the permanent way of the South-Western line since the disaster, and one or two of the ladies could hardly be induced to step on board it. Once again, then, as is my wont, I disembarked in the midst of bad news. It was the earthquake at San Francisco three months ago; it was the Salisbury railway wreck to-day.

Here, then, ended my twelve weeks of roaming, ended pleasantly enough with this interesting and well-ordered cruise with the Tagus. "Travel," says an old writer-a namesake and collateral descendant of whom, a well-known resident of Trinidad, I was much interested to meet on this homeward voyage - "should not be merely a certayne gadding about, a vaine beholding of sundry places."

I have, as it happens, wandered but a little way from the beaten track. Yet I hope that the indulgent reader may of his grace acquit me of having made no more than a hackneyed pilgrimage of the kind ordered by the admirable Baedeker, facilitated by the resourceful Cook, and celebrated along all its commonplace route by coloured salvos of pictorial postcards to more restful friends at home.

These pages have touched on many interests, some of them, perhaps, on no interest at all to any but myself. Yet perhaps the reader may lay the book down in the indulgent spirit of the elder Pliny, who remarked that no book was so bad but that some part of it was of use. Books were less numerous in his day, else he might have reconsidered so rash a pronouncement. 


\section{INDEX}

ABOLITION, war of, 73

AEthurus, 210

Aflalo, F. G. (tarpon caught by), I 37, I 38

Africa, tarpon on West Coast of, I09

Agriculture in Carolina, 70

$" \quad$ Cuba, 196
Jamaica, 207

Ailments of captive beasts, 32

" fishes, 37

Alinas, Manuel (guide), I37, 138

Alleghanies, the, 57

Alligator hunt, an, $158-163$

Alligators in captivity, $31,182,183$

" Florida, 9x, $158-163$, I70

" natural history of, 164 , 165

American biscuits, 23

, carelessness of deadly snakes, 172

children, 7 .

cigars, 25

coffee, 23

drunkenness, 22, 23, 177

food, $22,23,24$

influence in the West

Indies, 200, 201, 218

melodrama, 26

men and women, 6 national anthems, 9 race prejudice, 8

tea, 24

theatres, 25-27

wages, 22

Americans, Cuban, opinion of, 186

Amyas Leigh, 254

Ancon Hospital, 225, 243

Anecdotes, $43,59,163$

Anheuser Busch, I 30

Annotto Bay, 229

Anopheles, 173, 223, 224, 243, 244
Anthems, national, 9

Antilles, The, 257

Antoine, Lake, Iro

Antonio, Port, 227, 228

Antrostomus, 166

Apollinaris, 22

Aquarium, the New York, 34, 3540

Aransas, tarpon-fishing at, I09

Archosargus, I 55

Aristelliger, 213

Asafœetida, 173

Asheville, 58, 59

Atlantic and Pacific Oceans compared, 240

Audubon in Florida, 167

" society, the, 167

Avogado pear as bait for mountain mullet, $23 \mathrm{I}$

BAGGAGE on railroads, 47,77

Bahamas, fishes from the, 40

Baits for tarpon, I $18-120$

Baltic herrings, 104

"mosquitoes on the, 224

Baltimore, pretty women at, 50

Bananas, 204, 205, 218, 227

Baranquilla, 253

Barbados, barracouta at, 220

$"$ healthy climate of, 259
natives of, 247, 259,
260

"turkey-buzzard at, 194

Barracouta, 220, 22 I, 254

Bass, black, 67

" channel, I 53 , I 54

Bates, Miss Blanche, 26

Bathing, sea-, 219, 220

Bears, 28, 64, 169

Behring Sea arbitration, 37

Belasco's theatre, 26

Benson, Captain, 250, 253, 255, $26 \mathrm{r}$

Bergall, 39

Bermuda, fishes from, 40 
Bertram, The Hon. L. J., 110, 230

Bethel (guide), 138,139

Bigelow, Mr Poulteney, 237

Biltmore, estate of, 29,58

Bindley $\mathrm{Dr}, 260$

Biscuits, American, 23

Bison at the Zoological Park, 28

"Blackbird," the Jamaica, 2 II

Black River (Jamaica), I 10, 231

Blood worms, 227

Blue Fleet, our capture by the, 26 I

" mountain coffee, 207, 218

" tailed duck, 68

Boar, Cuban, 195

Bobolink, 168

Boca Grande, fishing at, 89, 93 , $94,97,103,106,109,110,118$, II 9 , 130, 134, 150, 177

Bogue Islands (Montego Bay), 220, 222, 226

Bog Walk (Jamaica), 229

Books, the elder Pliny on, 262

Bourne, Mr Clarence, 45

Bowery, the, 25, 28, 33, 44

Breams, sea, 222

Breeding-time of tarpon, 109

Bridge mania, the, 130

Bridgetown, 258, 259

Bronx, 27, 31

Brooklyn Bridge, crowds on, 19

Brook trout, 53, 67

Brute strength in tarpon-fishing, I 44

Bulkhead doors on the Caronia, 12

Bulletin, the daily (on s.s. Caronia), II, 16

Bull-frogs, 63

Burrowes, Mr John (Toxaway), 60

Burrowing animals, 147

Buteo, 210

Butterfish, 222

Butterflies, 64, 173, 195

Buzzard, 210

Bylasky, Ramong (guide), 137

CABARITTA RIVER (Jamaica), 23 I

Cabs in Havana, 203
" Kingston, 203
," New York, 18

California, tuna in, 109

Calipeva, 216, 230

Call for alligator, 162

" quail, 166
Caloosahatchee River, 91

Camp Fires in the Canadian Rockies, 28 f.n.

Canal, the Panama, 233-248

Cane rat, 208

Canvas-back duck, 216

Captiva Pass, fishing at, 93, 149

Caracas, railway to, 254

Carbolised vaseline for mosquitoes, 227

Cardinal, the, 63,168

Caribbean, the, $109,136,180,240$, 245

Carolina, North, $57,6 \mathrm{r}$ South, 70

Caronia, R.M.S., 2-16

Carrier pigeons on board ship, 26I

Cars in Jacksonville, $7 \mathrm{I}$

" Kingston, 7I

" New York, 2I, 4I

Cartagena, 250, 251, 252, 253

Catfish, 155,156

Cathedral at Cartagena, 252

"Santiago, 197

Cattle-breeding in Cuba, 196

Cavalli, 260 Jamaica, 205,

"Cave" of the alligator, $16 \mathrm{I}$

Cayman Islands, 214, 220, 222

Cedar, 193

Cedar Valley (Jamaica), 205

Ceylon, mosquitoes in, 224

Chagres River, intractability of the, 242

Channel Bass, 153,154

Character of the tarpon, I05

Charlotte Harbour, I2I

Chase, W. H. (tarpon caught by), I 37

Cherokee words, 65

Chicken-hawk, 2 ro

Chinese labour for Panama, 247

Chivalry not dead in the States, 78

Chordeiles, 213

"Chucky Joe," 65

Churchill, book by Mr Spencer, IOI

Ciego di Avila (Cuba), 193

Cigarettes in America, 25

Cigars 25, 192

Civil War in America, 73 
Civil War in Cuba, 200

Clams, little neck, 22

Clothing for fishing, 86

alligator-hunting, 159

Clubs", $188,203,216,252,258,259$

Cobia, the, $126,153,154$

"Cockpit Country," the (Jamaica), 220

Cocoa grown in Jamaica, 207

Codrington College (Barbados), 260

Coffee drunk in America, 23

, grown in Jamaica, 207

Cold storage on the Caronia, 13

Colombian ports, $25 \mathrm{I}$

Colon, character of, 240

tarpon at, 98, 105, 248

Colonial expansion, ethics of, 234

Colour question in the States, the, $7 \mathrm{I}, 201$

Columbus, the bones of, 190

Concert on board ship, 8

Conch, 170

Confederate, reminiscences of a, 73

Congressional Library, 55

Conrad, Mr, 159

Limited, the, 43

Conran Mr H. (Jamaica), 205

Constant Springs Hotel (Kingston), 203

Constantine, the late Captain, 203,232

Coral-keys, 175

Cornwallis Harris, 167

Corradores, 189

Cost of tarpon-fishing, 87, 95-99

Costa Rica bananas, 218

Cotton trees, 204

Crab, black, 203,216

" fiddler, $143,156,157$

" soft-shelled, 22

"Crackers" (biscuits), 23

") (natives of Florida), I 57

Creole, horsemanship of the Jamaica, 205

Creole's indifference to mosquitoes, 224

Cristobal quarter, the (colour), 234

Croaker, the, 213

Crocodile, the Florida, 164, 165

Crotophaga, 2 II
Cruelty to animals in Havana, 185

Cuba, 23, 175, 180-197

Cuba railroad, 192,193

Cuba Street (Havana), 195

Cuban opinion of Americans, 186

Culebra Cut, the, 40, 235, 245

Culex, 223, 224

Cunard boats, 2-16

Cunner, 39

Curlew, call of the, 166

Curtains, mosquito, 173

Customs, Havana, I 82

"New York, 15

Cynoscion, 155

"DAMFOOL-COOK," I87, 242

Dampier at Panama, 242

David Harum, 6

De Avilès, 9I

Deer, 64, I95

De Lesseps, 234, 236

Delmonico's, 22, 169

Desborough, Lord, $53,94,144$

Diamond-back terrapin, 216

"Dickie" (fisherman at Montego Bay), 22I

"Dixie for ever !" 6r

Doctor's Cave, bathing at (Montego Bay), 209

Dominica, beauty of, 205, 229

Dragon-flies, 195

Drake at Cartagena, $25 \mathrm{I}$

Driving, pleasures of, 60

Drummer, the lady, 187

Drunkenness in the States, 22, 23,177

Dublin Zoo, lions in the, 30

Duck, wild, 68

EAGLE, the American, 128

Earthquake in Jamaica, 232

Eating-houses, 23, 78, 183, 191

Egrets, 8I, 167, 168

Elder Dempster, Messrs, 218

Elephantiasis, 227

Elevators, 20

Emigrants, 3, 4

Empire, dispensary at (Panama), 243

Engines, visit to the Caronia's, II, 12

Epidemics in Zoological Gardens, 32 
Espeut, 208, 21I

"European plan," the, 78

Ewarton (Jamaica), 204, 206

Express Companies in the States, 48

FAIRFIELD, Lake, $64,66,68$

Falco, 2 Io

Farlow, Messrs Chas., 98

Fearon, Mr (Cartagena), 252

Ffennell's annual list of salmon, $\mathrm{Mr}, \mathrm{IO}_{2}$

Fiddler crab, $143,156,157$

Finlay, Dr (Havana), I94

Fin-ray, tarpon's long, Ior

Fire, the ordeal by, 70

Fireflies, 173, 217

Fish Commission, the U.S., 40

Fishery laws in Carolina, 67

" Jamaica, 231

Fishing" off Boca Grande, 83-I 52

, Bridgetown, 260

" Cartagena, 250, 251

" Jamaica, 231

"La Guaira, 254

" Punta Gorda, 79

, Savanilla, 253

, Toxaway, 65-67

"Useppa, I 54, I 55

Five-cent fare, creed of the, 2 I

Flat-iron buildings, $20,3 \mathrm{I}$

"Flicker," the, 63

Flies, trout (for Toxaway), 66

Florida, bird-life in, $165-9$

" coast of, I75

" fishing in, $79,80,83-157$

" food in, 78

" railroad travel in, 70,75

" suited to wild birds, 168

Fly for tarpon, 120, 149

Flying cage, the, $3 \mathrm{I}$

" fish as food, 259

Food at Bridgetown, 259

" in Florida, 78

" Havana, 184

" Jamaica, 203

" New York, 22

" Port of Spain, 258

" railroad dépôts, 193

" on board ship, $\mathrm{I}_{3}$

Forest and Stream (quoted), 146

Fort Myers, 76, 92, I 50

Foul-hooked fish, 134

"Four Hundred," the, 4I
Franklin, Benjamin, 128

Fraternity, the Republican ideal of, 42

Free trade, America against, 15

Frontiersmen's league, the, 122

Fronton, the (Havana), I 88

Fruit-growing in Cuba, 196

$$
\begin{array}{ll}
" & \text { Florida, } 75 \\
& \text { Jamaica, 218 }
\end{array}
$$

GAFFS and gaffing, $116,117,125$, I47

Galeichthys, 155

Galveston, a fatality off, 149

Gambusia, 39

"Garden of Jamaica," the, 204, 205

Garfish, I 54

" as bait, II9, 221

Garrupa, I 53

Gasparel Island, $110,116,169$

Gecarcinus, 216

Gecko, 213

Geese, white-fronted, 30

Gelasimus, 156

Geographical distribution of the tarpon, 108

Georgia, 70

German Club at Havana, 188

Gilead Beck, I9

Gills of the tarpon, 102

Goats, Rocky Mountain, 28

Gordon-Cumming, 167

Gorgas, Colonel, 40, 54, 194, 223, $239,243,244$

Gorge-fishing, 149

Gosse, 208

Grabham, Dr (Kingston), 225

Grassi, Prof., 223

Green turtle, 215

Grenada, tarpon in, IIO

Griffith, $\mathrm{Mr}$ (H.B.M. Consul, Havana), 182

Grouper, 86, I 34, I 54

" black, 153

"red, I 53

Grouse, ruffed, 63,68

Grunt, the, I 55

Guadaneros (Havana), I8I

Guide to the N. Y. Zoological Park, 33

Guides, tarpon, cost of, 68

$$
\text { "gaffing done by, }
$$


Guinea grass, 192, 196, 206, 211 Gulf of Mexico, 85, 86, 90, 106, 153

Gulf Stream, 154, 238

Hamamelis, 227

Hammond, Gardiner G. (tarpon caught by), 137

Harbour of Havana, I8I

" Kingston, 197

Harbours, memorable, I5

Hardy Bros., Messrs, 98

Hart, $\mathrm{Mr}$ (Montego Bay), 219

Hat, a useful, 73

Havana, beauty of, 180,181

" cafés of, I9I cruelty to animals in, 185 Customs House, 182 German Club at, 188 Jai Alai at, 188 public holiday at, 184 , 185

" Spanish character of, 183 " students of, 185

Hawksbill turtle, 2I5

Heincke, Prof., 104

Hendersonville, 69

Herons, 166

Herpestes, 208

Hippodrome, the New York, 27

Hog-nosed mullet, 230

Holbrow, Mr, 98

Holder, Mr C. F., 100

Hook, the tarpon, II 5

Hornaday, Mr W. T. (Director of the Bronx Zoological Park), 27, 28,103

Horse Pasture River, 6I

Horses, Cuban, 196

Hotels in Florida, 80

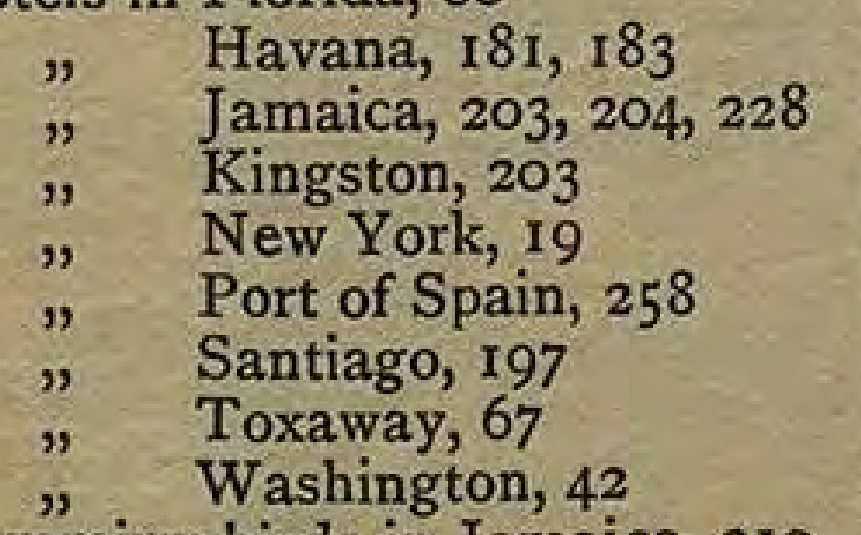

Humming-birds in Jamaica, 210

$$
\text { " }
$$

on board ship, 255

Hustle, the Gospel of, I9

Hutia, the, 195
IBEX in captivity, 28

Ibis, 169

"Independence Day" (Havana), $176,184,185$

Inglaterra Hotel (Havana), 18 I

Inquisition, the, 252

Isthmian Canal (see also Panama), 178

" Zone, 233,243

JACK (taxidermist at Useppa), I58, 159

Jack-pines, 62

Jacksonville, 48, 70-74

Jai Alai, game of, 188

Jamaica, $199-232$

" Club (Kingston), 203, 216,232

$" \quad$ industries of, 217

" railways of, 204,229

" tarpon in, IIO, I4I

" tourist attractions of, 229

" withdrawal of troops from, 198

Java, mosquitoes in, 224

Jewfish, 86, 89, 108, I26, 134, I53, I 54,176

"John Crow", 210, 212

Johnston, Sir Harry (quoted), 260 Jordan, Prof., 100

Jumping peenie, the, 217

"KEY of the New World," 177

Key West, appearance of, 178

" drunken man at, 23

" future importance of, 178 voyage to, 175

Key", Florida, 90

Kingfish, $90,119,153$

Kingfisher, 168

Kingsley, L. W. (tarpon caught by), 137

Kingston, 203, 204, 231, 232

Kru boys, 260

LABELS for aquarium tanks, 38 , 39

Labour difficulties at Panama, 246,247

$\mathrm{La}$ Costa Island $158-163,169$, 172

Ladyfish, 155

Lagodon, 155 
La Guaira, 254

Lakeland, 48, 76, 8 I

Lancaster, Mr (Purser on the Caronia), 9

"Land of the Sky," 64, 68

La Popa (Cartagena), 253

Laws, Captain (of H.M.S. Tagus), 248,254

Leatham, Charles (guide), 137, 138,139

Leeward Islands, the, 257

Leicester, Mr (lighthouse-keeper at Boca Grande), I10, 122

Leopard shark, 129

Letters of credit, 44

Levera, Lake, I 10

"Liberia," by Sir H. H. Johnston, 260

Liberty, the republican ideal of, $4 \mathrm{x}$

Line, the tarpon, $\mathrm{I}_{3} 3$

Lion houses, 32

Literature, zoological, 33

Lizards of Jamaica, 2I3, 2I 4

Lock type of canal, 235

Loeb, $\mathrm{Mr}$ (Secretary at the White House), 52

Loggerhead turtle, 169, 215

London, Mr Jack, 159

Louisiana heron, the, 169

Loxigilla, 210

Luck in fishing, $89,142,143,144$

Lumsden, Col. D. M. (tarpon caught by), 137, 138, 139

M'CATTy, Dr (Montego Bay), 225

$M^{\prime}$ ' arlane, $\mathrm{Mr}$ (chief engineer on the Caronia), II

M'Guire, Fulton (guide), I 37

W. W 138

Machete, uses of the," 196

Machina, the (Havana), 182

Madeira, 109, 156, 162, 222

Magdalena, the, 254

Maine, wreck of the, $18 \mathrm{r}, 187$

Maja, the, 194

"Make him jump," 86, 124

Malaria, $173,226,227,243$

Malecon, the (Havana), 184, 190

Mallard, 30

Mandeville, 204

Mangroves, 9I

Man-o'-war hawk, 81, 90
Manson, Sir Patrick, theory touching the Panama Canal, 238

Manson, Sir Patrick, work done by, 223

Marconi telegraphy, IO, II

Maria, Port, 227

Mark Twain at the Carnegie Hall, 16

Martinique, negroes of, 24

"Mason and Dixon line,' the, 6I

Maxwell, Sir H., Ioo

Mediterranean, Cunard cruise in the, 6

Megalops, 100 tunny in the, 109

Mellor, A. K. (tarpon caught by), 138

Melodrama in America, 26

Mende tribes, the, 260

Merlin, 210

Mexico, tarpon-fishing in, 109

Milk River (Jamaica), I Io

Millionaires, 3,29

Mimus, 166

"Minnow" bait, I55

Miraflores, dispensary at

(Panama), 243

Miramar, the (Havana), 184,188

Mitchell, Dr Chalmers, 36

Mocassin, 3I, 170

Mocking bird, $60,89,165,168$, 179

Moneague (Jamaica); 203, 204, 206, 209, 210,212

Monkeys in Jamaica, 209

Montego Bay, 210, 216, 219, 223

Moonlight fishing, 86

Morro, the (Havana), I8I, 190

(Santiago), 197

Mosquito coast, the, 214

Mosquito-hawk, 213

Mosquitoes in Cuba, 194, 195

" Florida, 75, 106, 173

" $\quad$ Havana, I7I $220,223,224$

" Panama, 239

" Toxaway country,

Mount Morgan, 69 64

Mountains, railway travel in, 58 , 229 
Mouth of the Tarpon, 102

Mullet bait, $x 18$

Mullet, hog-nosed, 230

" mountain, 23I

" silver, 154

Mungoose, 208, 209

Muntz, G. D. E. (tarpon caught by), $137,138,139$

Mus, 208

Myers, see Fort Myers

Mygatt, accident to $\mathrm{Mr}$ Otis, 149

Myiarchus, 212

Myrtle Bank Hotel (Kingston), 203,215

NAETHING, C. F. (tarpon caught by), 138

Natural History, Hornaday's, 103 Nashville (American cruiser), 234

Negro, types of, 247, 259

Newfoundland, tunny near, 109

New Willard Hotel(Washington), 42

New York cabs, 18

$$
\begin{aligned}
& \text { " cars, } 2 \mathrm{I}, 4 \mathrm{I} \\
& \quad \quad \text { crowds, } \mathrm{I} 8, \mathrm{I9}
\end{aligned}
$$

" customs, 15

" elevators, 20

" harbour, 15

"hotels, 19

" personal liberty in, 4 I

" skyscrapers, 20

" subways, 20

Nicaragua Canal route, proposed, 235

North Sea herring, IO4

OBservation CAR, 50

Olivette, s.s., 23, 176, 177, 181

Ora Cabessa, 227

Orange Hall (Jamaica), 204, 213

Orchids, 204

O'Reilly, the (Havana), I84

Orinoco, R.M.S., 197

the river, 257

Ostrich farm at Jacksonville, 72

Oteri, s.s., 197

Ottaray, 64

Ouananiche, 67

Oysters, mangrove, 220

Pacific and Atlantic Oceans, compared, 240
Palms, 204

Pam, Captain, 255, 261

Panama, Isthmus of, 40,233 249

" sanitation work at, 244

" shells, 170

" town of, 240

Para grass, 206

"Parmachene Belle," the, 66

Parrakeets, 210

Parrot, roast, 216

Pass-fishing, I2I-149

Pastel, a delicious, 258

Patti, début of Madame, 197

Pelicans, 75, 8I, 89, I2I

Pelota, 188,189

Peninsular and Occidental S.S.

Co., 176

Pennsylvania, 62

Petchary, 212

railroad, the, 47

Pets on board ship, $25 \mathrm{I}$

"Pheasant" (local name for the ruffed grouse), 63

Philadelphia, 7,50

Pigeon-hawk, 210

" shooting in Jamaica,

Pimento, 204, 207

Pinar del Rio (Cuba), 192

Pinfish, 155

Pipe-smoking in America, 25

Pitangus, 212

Pitch in Trinidad, 257

Playing a tarpon, 125, 145

Playing the game, 189

Pneumonia, 243

Poland water, 22

Polo in Jamaica, 204, 213

Pompano shells, 170

Ponce de Leon, fate of, 180

Poplar, 62

Population, density of, in Barbados, 258

" Cuba, 195

" New York, 18

Port Antonio, 227, 228

Maria, 227

" of Spain, 232, 256

" Royal, tarpon at, iro

" wicked reputation of, 197

"Tampa, 108, 175, 176

Porto Colombia, 253

Prada, the (Havana), 184 
Pratt, Charles (guide), 137,138 , 139

Prawn bait for tarpon, 120 , 149

Promicrops, 153

Protection of wild birds, 169

Punta Gorda, 48, 74, 77-8I, 91

Pyrophorus, 217

QUAIL, I68

" call of the, 166

Queen's Park Hotel (Port of Spain), 257, 258

Queenstown, 3

Quinine, 226

Quiscalus, 2 II

Rachycentron, 153

Railroad travel in America, 43, 44, 46-50, 57-59, 75, 76

Railroad travel in Cuba, 192-197 " England, 1 " Jamaica, 219,

Rain at Havana, 191 229

" Port Antonio, 228

" Port of Spain, 228

Rainbow trout, 53,67

Raleigh holds North Carolina, 6r

Ramsbottom, G. H. (tarpon caught by), $137,138,139,142$

Rattlesnakes, 169, 171, 172

Rays, leaping, 87, I 53

Red bug, 173

Reel, the tarpon, $96,97, \mathrm{II}_{2}$, II 3

Remoras, 153

Reptile Houses, $3 \mathrm{I}$

Reptiles of Florida, I70, 172

"Jamaica, 21 3, 214

Republican ideals, $4 \mathrm{I}, 42$

Rifle detained at the Havana Customs, 182

Ringtail pigeon, 216

Roach, Mr(Owner of Useppa), 155

Road, rule of the, 24

Roderick Random, memories of, 250

Rod-rest, 116

Rod, the tarpon, $96,112,140$

Roosevelt, estimate of President, 55 interview with, $5 \mathrm{I}$

Roper, Mr (Jamaica), 204, 213

Rose Salterne, memories of, 254

Ross, Major Ronald, 223
Royal Mail, S.S. Co., 215

Ruffed grouse, 63,68

Rum, 218

ST ANN (Jamaica), 204, 2 II

St Paul on thirst, 2I

Salmon and tarpon-fishing, compared, 87

Sanabel Island, 158

Sanborn, $\mathrm{Mr}$ (photographer to the N.Y.Z.S.), 33

Sancho Panza (quoted), 2 I

Sandy Hook, 14

San Francisco, earthquake at, 19 , I7

Santa Catalina, 95

Santa Clara (Cuba), 192, 193

Santa Cruz (Cuba), 195, 207

Santiago di Cuba, 196, 197, 207

Sapphire, Lake, 63,66

Sargo, 156

Saturday Reviezw, Mr E. Selous in the, 29

Savanilla, 232, 253

Sawfish, 154

Saw-grass, 160

Scales, tarpon, 102

Scionops, 153

Scomberomorus, 153, I 55

Sea-level type of canal, 235

Sea-lions, 32, 37, 56

Seals, 30

Season for tarpon-fishing, 106

Selous, Mr E., 29 " Mr F. C., 53

Seminole Indians, 160

"September," the, 212

Setting up tarpon, cost of, 99

Settlements in Cuba, alien, 195

Sharks, $84,86,89,127-130$, 145 , 153, 254

Shaw \& Jack, Messrs, 99

Sheepshead, 155,156

Shells of the Gulf shore, 170

Sherry's, 22, 169, 177

"Shiner," the, 155

Ship, life on board, 5,260

Shonts, $\mathrm{Mr}$ (in favour of Chinese Labour), 247

Sierra Leone, negroes from, 260

Silk-fish, 222

Silver mullet, $\mathrm{I} 54$

Sinclair, $\mathrm{Mr}$ (author of The Jungle), 4 


\section{INDEX}

Sinkers for tarpon-fishing, 96, I 14 Skill in tarpon-fishing, 145

Skinner, Mr (Port of Spain), 258

Skyscrapers, 18, 20

Slave Coast, miles of the, 260

Slavery, the question of, 74

Smokers and smoking in America, 25

Snakes, 63, 91, 170-172, 213

Soquilla, the, 66

Southern Railroad, the, 57

Spada, the, 222

Spanish mackerel, I 55, I 56

" Main, the, 106, 250-255

" town (Jamaica), 204, 23I

Sparrow, the black, 210

Sphyrana, 220

Spices, 207

"Spiggoties," I83, 24I, 254

Sporting ideals, 83

Squeateague, the spotted, 80, 155

Squirrels, 64

Starling, imitative powers of the, 165

" proposal to introduce the, into Jamaica, 2 II

"Star-spangled Banner," the, Io, $6 \mathrm{r}$

Steam-shovels on the Isthmus, 245

Steerage, life in the, 7

Stegomyia, 223, 227, 238, 239, 243, 244

Steller's sea-lion, 56

Stevens, $\mathrm{Mr}$ (late chief engineer to the Panama Canal), 235

Still-fishing, II 5, 120, I 49-1 52

Stores of the Caronia, I3, I4

Subways in New York, 20

Suez Canal, 75, 24I

Sugar-cane, 204

$" \quad$ mills in Cuba, 196
$" \quad$ planting in Jamaica,
$205,207,217$.

Sullivan, $\operatorname{Mr}$ (acting chief engineer at Panama), 245

Swannanoa, the, 58

TABLETS, turtle, 216

Tackle, tarpon, $84,112-117$

Tagus, R.M.S., 2 I $5,2^{2}, 2 \mathrm{I}-263$

Tail, the tarpon's, IO2

Tampa, 176
Tampa Port, 108, I75, 176

Tampico, tarpon-fishing at, 108

Tanks, decoration of aquarium, 38

" labels for, $3^{8}$

Tarantula, 216

Tarpon-fishing, 83-I 52, $23 \mathrm{I}$

Tarpon, character of the, 105

" baits for, II $8-120$

$" \quad$ cost of setting up, 99

$"$ distribution of, 108

" food of, ro4

" natural history of, IooI II

" scales of, 102

" size and weight of, 88 , 102, 107

ways of losing a, 147

Tate, H. B. (tarpon caught by), $137,138,139$

Tautogolabrus, 39

Tea drunk in America, 23, 24

"grown in Jamaica, 207

Temne tribes, 260

"Tenderloin," the, $4 \mathrm{I}$

Texas, tarpon-fishing in, 108, 109, II9

"The Girl of the Golden West," 26

The Jungle, 4

Theodore Paleologos, 258

Thomson, $\mathrm{Mr}$ (head keeper of the London Zoo), 256

Ticks, 196, 206, 209, 211

Times, the, 103

"Ting-ting," the, $2 \mathrm{II}$

Tip declined, a, 246

Titchfield Hotel (Port Antonio), 228

Tobacco grown in Cuba, 192, 193, 196

"Tom-fool," the, 212, 213

Top-minnow, the, 39

Tortoises, 170

Tourist resort, Jamaica as a, 219

Townsend Mr (curator of the $\mathrm{N}$.

Y. Aquarium), 36

Toxaway, 59-68

"Toxaway," the, 63

Travel, cost of, 96

"virtues of, 262

Tree-ferns, 204

Trent, R.M.S., 231

Trinidad, 257,262 
"Trout" in Florida, 80, 155

Tuckaseegee, the, 67

Tuna or Tunny, $83,95,109$

Turkey, wild, 68

Turner Turner, Mr, 94, 101, 106, I1 8

Turtle-crawis, 225 Mrs, $94,103,133$

Turtles, $90,134,169,214,215$

Types of tarpon, 104

UNDERHILL, GEORGE (guide), $123,125,126,127,128,129,131$, $132,135,137,138,158,159,160$, $16 \mathrm{r}, 162$

United Fruit Company, the, 20r, $218,220,227$

United Railways, the (Cuba), 192

Upmann, Messrs (Havana), I84

Useppa, life at, 76, 82-175, 180

"record for $1906,137-9$

VANDERBILT, Mr (of Biltmore), 29,58

Van Vleck, Mr, 133

Vegas, tobacco, 193

Venezuela, ports of, $25 \mathrm{I}$

Verbosity of the nigger, 202

Verley, Mr (Jamaica), 231

Vernacular of American railroads,

"Virginia Nightingale," the, 63

Vom Hofe, Mr, 96, 97, 113,134 , $142,143,148$; (tarpon caught by), $137,138,139$

Voodoo worship, I7I

WADDELL, J. A. L. (on ways of losing a tarpon), 146, 147

Wages in America, 22

" Panama, 247

Walton, Izaak, 100

Ward, Mr Rowland, ror
Washington, elegance of, 50

Washington, George (at Barbados), 259

Wasps in a boat, 173

Water, iced, 24,216

Waterfowl as distributors of fish, I Io

Water-telescope, 214, 220, 221

Ways of losing a tarpon, 147

Weakfish, 155

Weight of tarpon, 89, 103, 107

West farms, 2I, 33

"Indies, IOI, 109, 120, 149 , $180-232,257-260$

Westmoreland (Jamaica), 110,205

Westward Ho! memories of, 250

Whip-poor-will, 60, 166, 167

Whipray, 90

"White bait"for tarpon(Jamaica), 120

Whitehead, Alfred (guide), 137 , $x_{3} 8,139$

Julius (guide), 137

White "House, yisit to the, 52

White Rock Water, 22

Winchester, the sporting, 158

Windward Islands, the, 125,258

Witch-hazel, 227

Woodpeckers, 63

Woodring, Sam (guide), 137

Wrecks, railroad, 46,197

YeLLOW fever, 227

Yellowtail, 83

ZIGZAG, railroad to, 254

Zoological Park, New York's, 27-

at Washington, 56

Zoos at home and abroad, 30 

